\title{
7. TAXONOMY, MORPHOLOGY AND PHYLOGENY OF THE NEOGENE DIATOM ZONAL MARKER SPECIES IN THE MIDDLE-TO-HIGH LATITUDES OF THE NORTH PACIFIC ${ }^{1}$
}

\author{
Fumio Akiba, Central Technical Laboratory, Japan Petroleum Exploration Company \\ and \\ Yukio Yanagisawa, Geological Survey of Japan ${ }^{2}$
}

\begin{abstract}
Based on both light microscopic and electron microscopic observations, taxonomic refinements of most of the Neogene diatom zonal markers of the middle-to-high latitudes of the North Pacific produce a firmer basis for its zonal frameworks. Denticulopsis (defined by Simonsen, 1979, and by far the most important genus biostratigraphically) is subdivided into Crucidenticula n. gen., Denticulopsis emend., and Neodenticula n. gen., based on submicroscopic features and phylogenetic relationships. All species belonging to the three genera recognized in Japan and its environs are discussed and illustrated in detail. The plicated members of genus Coscinodiscus, including C. temperei and C. yabei, are transferred to Thalassiosira. In total, 38 species are described in this paper.
\end{abstract}

\section{INTRODUCTION}

Neogene diatom biostratigraphy of the middle-to-high latitudes of the North Pacific has developed rapidly during the past decade, ever since Koizumi $(1973 a, b)$ established the Miocene through Quaternary diatom zonal framework for the region, zonations that have proved useful for age assignments and correlations of Neogene sediments of the region. Several biostratigraphically important diatoms (such as Thalassionema schraderi Akiba, Denticulopsis praedimorpha Barron ex Akiba, and D. katayamae Maruyama) have been only very recently recognized as the zonal markers, because they had hitherto been either confused with their closely related species or curiously described from a taxonomic point of view (Akiba, 1982a,b; Maruyama, 1984). Other species remain to be studied in more detail taxonomically and morphologically.

In the present report, therefore, the taxonomic and morphologic descriptions of these important diatoms are given in order to build a firmer basis for the biostratigraphic framework of the region. Our study is based on both light microscopic and electron microscopic detailed observations and was initially intended to treat all the species with the greatest detail possible, but time did not permit such a comprehensive analysis. Accordingly, only limited comments are given for those species not observed in detail. Some species treated here, however, are supported by citing either original descriptions or other good descriptions. They are necessary for this chapter in order to avoid unnecessary repetition and to present our observations and comments more clearly.

\footnotetext{
${ }^{1}$ Kagami, H., Karig, D. E., Coulbourn, W. T., et al., Init. Repts. DSDP, 87: Washington (U.S. Govt. Printing Office).

2 Addresses: (Akiba) Central Technical Laboratory, Japan Petroleum Exploration Co. Ltd., 3-5-5, Midorigaoka, Hamura-cho, Nishitama-gun, Tokyo 190-11, Japan; (Yanagisawa) Geological Survey of Japan, 1-1-3, Higashi, Yatabe-cho, Tsukuba-gun, Ibaraki-ken 305, Japan.
}

The diatom species to be treated here are shown in the Appendix at the end of this chapter. All zonal marker species and the closely related forms in the modified Neogene diatom zones of the region (Akiba, this volume) are also included except for Thalassiosira spinosa. In addition, several low-latitude species rarely found in the region are also treated, and the possible phylogenetic relationships of some species are suggested. Important taxonomic results in this paper include subdivision of the genus Denticulopsis into Crucidenticula n. gen., Denticulopsis Simonsen emend., and Neodenticula $\mathrm{n}$. gen., and the transfers of plicated Coscinodiscus species such as $C$. temperei Brun and $C$. yabei Kanaya into the genus Thalassiosira. Four new species are described, and thirteen new combinations are proposed.

\section{MATERIAL AND METHODS}

All samples used in the present investigation are chosen from a collection of the Central Technical Laboratory of Japan Petroleum exploration Company, Limited (JAPEX), Tokyo, Japan (JDS = JAPEX diatom sample). Most of them are from on-land Neogene sequences of northeastern Honshu and Hokkaido, Japan; the remainder are from DSDP cores and other sources. Light microscope (LM) and scanning electron microscope (SEM) observations were carried out by F. Akiba and Y. Yanagisawa, respectively. Preparation of diatom slides for LM is after Akiba (this volume). For SEM observations, diatom valves were picked up from cleaned samples and mounted on sample stages, using one hair of a tiny paint brush. SEM examination was carried out using Hitachi S-405 scanning electron microscope at the Geological Survey of Japan (Ibaraki-ken, Japan).

\section{REVISION OF GENUS DENTICULOPSIS SIMONSEN (1979)}

Simonsen (1979) erected Denticulopsis as a new diatom genus for those species that had hitherto been known as "marine species of Denticula Kütz." (Simonsen and Kanaya, 1961), because he noted significant structural differences between the genera Denticulopsis and Denticula s.s., of which species are restricted to marine and nonmarine habitats, respectively. The genus Denticulop- 
sis as defined by Simonsen (1979) is by far the most important of those used in the Neogene diatom biostratigraphy of the middle-to-high latitudes of the North $\mathrm{Pa}$ cific, because it includes many abundant short-ranging and widely distributed species (Simonsen and Kanaya, 1961; Koizumi, 1973a,b, 1977; Schrader, 1973a,b; Barron, 1980a,b, 1981; Akiba et al., 1982; Akiba, this volume). Its biostratigraphic utility was demonstrated for the first time by Simonsen and Kanaya (1961), who also described its basic structure and morphologic characteristics and differentiated five species, including one new species. Their terminology for many morphologic features of the genus has been basically followed by successive workers until now.

After Simonsen and Kanaya (1961), many new taxa of the genus Denticulopsis have been successively described from the Neogene of the North Pacific, the Southern Ocean, and the North Atlantic Ocean during the past decade (Schrader, 1973a,b, 1976; Schrader and Fenner, 1976; McCollum, 1975; Akiba, 1982b; Maruyama, 1984; Akiba, this volume); presently some 20 taxa are recognized, including several new species, which will be described later under different generic names. Among them only one species is extant, all others are evidently extinct.

The Japanese Neogene strata contain all those taxa except for three Antarctic forms (D. maccollumii Simonsen, D. lauta var. ovata (Schrader) Simonsen, and $D$. hustedtii var. ovata (Schrader) Simonsen), a yield that provides a good opportunity to study the genus as a whole.

Our observations on many "Denticulopsis" species showed that there are several fine structures, which were neither well understood nor found at all until now, and that the genus is presently heterogeneric in terms of the fine structures. The known members of the genus are morphologically divided into three groups, of which representative species are, $D$. nicobarica (Grunow) Simonsen, D. lauta (Bailey) Simonsen, and D. kamtschatica (Zabelina) Simonsen, respectively. In addition, stratigraphic and geographic distributions and morphologic characteristics of those groups suggest that they are phylogenetically separated from each other. Consequently, it is reasonable that the three groups represent the distinct genera: Crucidenticula n. gen., Denticulopsis emend., and Neodenticula $\mathrm{n}$. gen. Some distinct morphologic features are common among these three genera (such as general valve outline and pseudosepta with crossbars) and might be interpreted as results of parallel evolution. Most diagnostic characteristics of the three genera, such as size of punctae and type of marginal ribs, were already noticed by Simonsen and Kanaya (1961), but they regarded those as diagnostic of species among the "marine species of Denticula."

More than half of the zonal boundaries for Japan and adjacent areas are defined by the occurrences of species of the three genera (Fig. 1). Both Crucidenticula and Denticulopsis are now extinct; the former is limited to the lower-middle Miocene and the latter ranges from the upper lower Miocene through the upper Miocene.
On the other hand, Neodenticula appears in the uppermost upper Miocene and ranges to the Recent.

\section{Crucidenticula n. gen.}

Description. In girdle view, the frustule is rectangular with rounded corners. All species probably form chains by contact of valve faces. Cingulum consists of a copula and at least two pleurae. Copula is open, with a row of puncta; pleurae are open and smooth. The valve is linear-elliptical with broadly rounded apices and a relatively high mantle. The primary pseudosepta have crossbars. Marginal ribs are numerous, one between each two rows of transapical striae, rather variable in length in cases. Secondary pseudosepta are often present, but not regularly. Valve face and mantle have very distinct areolation, consisting of large puncta with cross-shaped rotae, arranged in multiple transapical striae between pseudosepta. Raphe is marginal along the edge of the valve face; two raphes of a frustule are on opposing margins. Raphe slit is divided into two branches. Raphe canal has circular portulae, two between each two pseudosepta. Entirely marine and fossil, possibly planktonic, this genus is mainly restricted to lowto-middle latitudes.

Type species. Crucidenticula nicobarica (Grunow) n. comb.

Remarks. This new genus resembles two other genera, Denticulopsis Simonsen emend. and Neodenticula n. gen., but is clearly distinguished from them by the following features and bears no possible phylogenetic relationships to those two genera.

1. One of the most conspicuous morphologic characters unique to this genus is very distinct transapical striae on both valve face and mantle; the number of puncta is easily countable by LM. Transapical striae of the other two genera are much less conspicuous. In addition, our SEM observations clarified a peculiar microstructure of these puncta, namely cross-shaped rotae inside each (Plate 3, Fig. 7; Plate 4, Fig. 6; Plate 5, Fig. 9), which are observed in all well-preserved species of this genus examined by SEM. No such structures are observed in any species of Denticulopsis Simonsen emend. or Neodenticula n. gen.

2. Another conspicuous characteristic is the numerous marginal ribs between pseudosepta on both margins, one between every two rows of transapical striae, whereas Denticulopsis has only one such marginal rib between the two pseudosepta or secondary pseudosepta on both margins, and Neodenticula has marginal ribs made by branching of pseudosepta or secondary pseudosepta only on one raphe-bearing margin and has no such marginal ribs at the other margin (Fig. 2). In addition, the marginal ribs of this genus have a tendency to be developed with variable degrees, and some well-developed marginal ribs show features similar to secondary pseudosepta.

3. The raphe slit of this genus is divided into two branches at the valve middle. A similar feature is observed in Denticulopsis, but that of Neodenticula is continuous without such branching. The number of portulae or "inner canal openings" (Simonsen and Kanaya, 1961) also seems to be unique to each genus. This genus has generally two portulae between each two pseudosepta, and its position bears almost no relationship to the marginal ribs, whereas Denticulopsis has one portulae between each two pseudosepta or secondary pseudosepta and its position is immediately above each marginal rib. In Neodenticula one portula is situated between each pair of marginal ribs (Fig. 2).

Stratigraphic and geographic occurrences. Although several species of this genus and Denticulopsis occur together in some horizons (Fig. 1), no phylogenetic relationships between those species are suggested. As will be suggested later, the oldest and most primitive species of Denticulopsis may be $D$. praelauta, based on information now available. This species typically has fine areolation and no marginal ribs. It occurs in lower Miocene sediments in which such Crucidenticula species as $C$. nicobarica, $C$. ikebei, and $C$. kanayae are also observed, but it is unlikely that one of those Crucidenticula species is ancestral to $D$. praelauta because morphologic differences between them are too large to assume such a link.

Geographic distributions of Crucidenticula and the other two genera are unique to each genus; Crucidenticula is a genus of the low-tomiddle latitudes, with most of its species dominant at low latitudes, whereas both Denticulopsis and Neodenticula are genera of the middle-to-high latitudes, with species of Neodenticula predominant at high latitudes. 


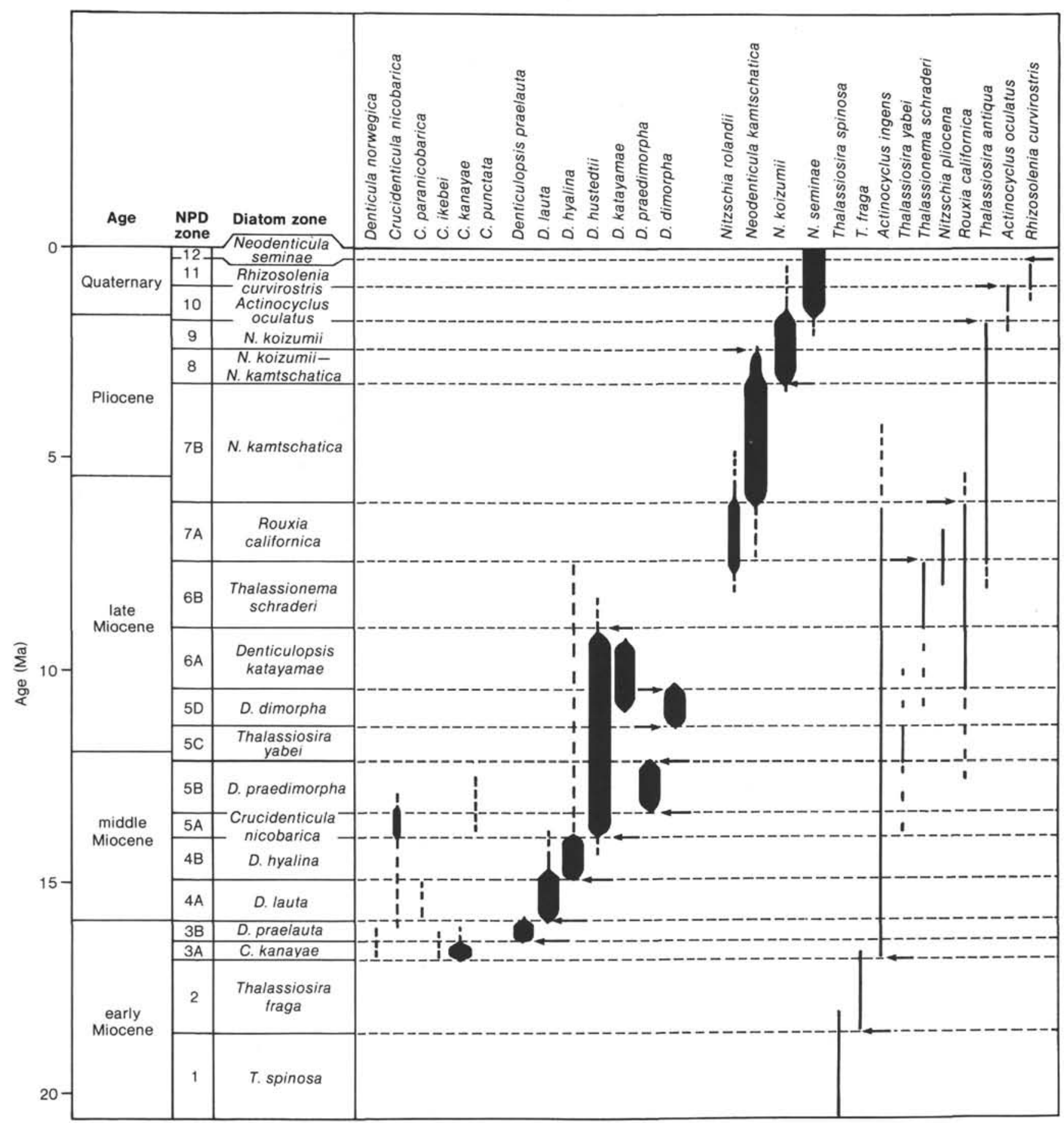

Figure 1. North Pacific diatom (NPD) zonation (Akiba, this volume) and stratigraphic ranges of selected zonal marker diatoms in Japan and its environs. The width of line of each species of Denticulopsis and its related genera is roughly in proportion to its relative abundance. Arrows indicate datum levels that define zone boundaries.

Crucidenticula ikebei Akiba and Yanagisawa n. sp. (Plate 1, Figs. 1-2)

Synonym. Denticula ikebei Akiba ex Barron, 1980a, p. 672, pl. 1, fig. 30 , nom. invalid.

Description. Valve is linear to linear-elliptical with elongated and rounded apices. Apical axis of some specimens is slightly heteropolar. Valve is almost flat: $41-63 \mu \mathrm{m}$ long, $6.5-7 \mu \mathrm{m}$ wide. No complete frustule was observed. Transapical striae are coarsely punctate, 10-12 in $10 \mu \mathrm{m}$; puncta are arranged not in clear quincunx, so that oblique rows are obscure. Puncta are rounded, about 10 in $10 \mu \mathrm{m}$, not deeply penetrated into valve interior; valve itself is shallowly constructed. Secondary pseudosepta are absent. Crossbars of pseudosepta are poorly developed, only easily discernible from biological inner side of valve. Marginal ribs are conspicuous and numerous, $10-12$ in $10 \mu \mathrm{m}$.

Holotype. Plate 1, Figure 1 from Sample JDS-5675, the Tsurikake Formation, Okushiri Island, southern Hokkaido, slide No. Zu 3/10 deposited in Hustedt Collection, Bremerhaven, West Germany, $58 \mu \mathrm{m}$ in length, $6.5 \mu \mathrm{m}$ in width.

Paratype. Plate 1, Figure 2, from the same sample as above, slide No. JDS-5675(7) deposited in the Central Technical Laboratory of JAPEX, Tokyo, $52 \mu \mathrm{m}$ in length, $7 \mu \mathrm{m}$ width. 


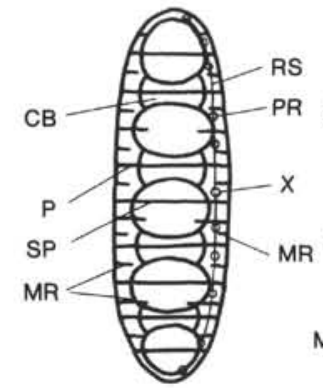

Crucidenticula

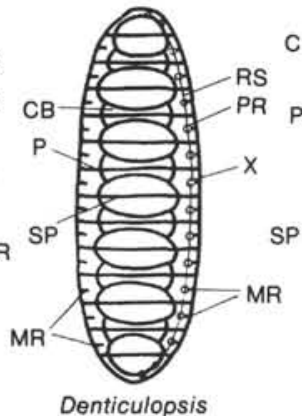

Denticulopsis

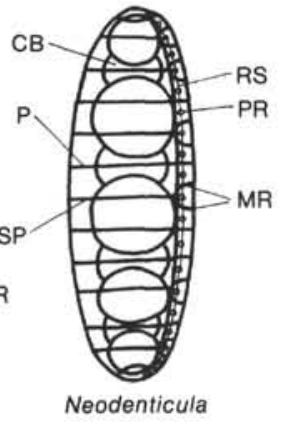

Neodenticula
Figure 2. Schematic drawings of general valve structures of genera Crucidenticula, Denticulopsis, and Neodenticula. P: pseudoseptum, SP: secondary pseudoseptum, MR: marginal ribs, CB: crossbar, RS: raphe slit, PR: portula of raphe, X: middle point of raphe slit where it is interrupted in Crucidenticula and Denticulopsis.

Stratigraphic occurrence. Rare in the lower Miocene Crucidenticula kanayae Zone (NPD3A) in general, but common to abundant in a sample from eastern Hokkaido, which is just below a sample with abundant $C$. kanayae (Akiba, unpublished data).

Remarks. No SEM observations have been made to date. This new species resembles $C$. paranicobarica $\mathrm{n}$. $\mathrm{sp}$. and Denticula norwegica Schrader, but differs from the former by its larger size and denser striae and from the latter by rounded apex and slimmer valve.

This new species is dedicated to Dr. Yutaka Ikebe, ex-general manager of JAPEX, who has given the senior author constant encouragement during the course of his diatom biostratigraphic investigations of Japan.

\section{Crucidenticula kanayae Akiba and Yanagisawa n. sp.}

(Plate 1, Figs. 3-8; Plate 3, Figs. 1-6, 9-11)

Synonym. Denticula nicobarica Grunow, Hata and Hasegawa, 1970, pl. 4, figs. 4a-6b; Denticula punctata Schrader, Schrader and Fenner, 1976, pl. 1, figs. 42, 43, not fig. 33; Denticula kanayae Akiba ex Barron, 1980 a, p. 672 , pl. 1, figs. 26-28, nom. invalid.; Denticulopsis kanayae (Akiba) Barron, in press a, nom. invalid.

Description. In girdle view, the frustule is rectangular with rounded corners, about $9 \mu \mathrm{m}$ in depth. Valve is very heavily silicified, very slightly convex, mostly linear-oblong, less frequently linear-elliptical, with bluntly rounded apices, 14-43 $\mu \mathrm{m}$ long, 4-8 $\mu \mathrm{m}$ wide. Transapical striae are very coarsely punctate, $9-10$ in $10 \mu \mathrm{m}$; puncta are not always arranged in clear quincunx. Puncta are rounded, about 6 in $10 \mu \mathrm{m}$, with a cross-shaped rota, which is only observed in SEM. Pseudosepta are about 2 in $10 \mu \mathrm{m}$, mostly in transapical directions, but (rarely) slightly oblique to transapical axis. Secondary pseudosepta not present, but rarely some specimens have one or two rudimentary pseudosepta that do not cross the valve face entirely but stop somewhere between the valve center and one valve margin. Pseudoseptum has a crossbar at its base, but rudimentary pseudoseptum is without such structure. Marginal ribs are very conspicuous, one between each two transapical striae, $9-10$ in $10 \mu \mathrm{m}$. Raphe is marginal.

Holotype. Plate 1, Figure 3, from Sample JDS-5676, the Tsurikake Formation, Okushiri Island, southern Hokkaido, Japan, slide No. Zu $3 / 12$ deposited in the Hustedt Collection, Bremerhaven, West Germany, $34 \mu \mathrm{m}$ in length, $8 \mu \mathrm{m}$ in width.

Paratype. Plate 1, Figure 4, from the same sample as above, slide NO. JDS-5676(1), deposited in the Technical Laboratory of JAPEX, Tokyo, $36.5 \mu \mathrm{m}$ in length, $6.5 \mu \mathrm{m}$ in width.

Stratigraphic occurrences. Very abundant in lower part of $\mathrm{C} . \mathrm{ka}$ nayae Zone (NPD3A) and rare occurrences in younger horizons up to lower part of Denticulopsis lauta Zone (NPD4A).

Remarks. This new species resembles $C$. nicobarica (Grunow) n. comb. and C. punctata (Schrader) n. comb. et emend., but differs from the former by the more thickly silicified and robust valve, and from the latter by larger and more irregular arrangement of puncta and their more or less linear shapes. This species has the coarsest puncta of all included in the genus (cf. Plate 3, Figs. 7-9). Denticula kanayae Akiba ex Barron (1980a) is invalid because no type specimen was designated.
This new species is sincerely dedicated to Dr. Taro Kanaya, former Co-Professor of Institute of Geology and Paleontology, Tohoku University, Sendai, Japan, who introduced the senior author to the study of diatoms and made important taxonomic and biostratigraphic contributions on marine species of Denticula Kütz. with Dr. Reimer Simonsen.

\section{Crucidenticula nicobarica (Grunow) Akiba and Yanagisawa n. comb.} (Plate 1, Fig. 9; Plate 2, Figs. 1-7; Plate 5, Figs. 1-9)

Basionym. Denticula nicobarica Grunow, 1868, p. 97, pl. 1A, figs. $5 \mathrm{a}-\mathrm{b}$.

Synonym. Denticula nicobarica Grunow, Simonsen and Kanaya, 1961 , p. 503, pl. 1, figs. 11-13; Schrader, 1973a, pl. 1, figs. 31-35; not Hata and Hasegawa, 1970, pl. 4, figs. 4a-6b; Denticulopsis nicobarica (Grunow) Simonsen, 1979, p. 65; Maruyama, 1984, pl. 15, figs. 12-13b; pl. 16, fig. 11.

Original description. Grunow, 1868 (in Latin, translated by Constance Sancetta): “Small $D$. (Denticula), valves narrowly linear, or linear-lanceolate with rounded ends, costae $12-14$ in $10 \mu$, striae punctate 24-28 in $10 \mu$. Length $10-13 \mu$; width of frustule $3-3.5 \mu$, width of valve $1.3-1.5 \mu$."

Full description. Simonsen and Kanaya, 1961: "Valves narrowly linear to linear-elliptical with bluntly rounded ends, $10-32 \mu$ long, 3.5-4.5 $\mu$ wide. Pseudosepta 4-5 in $10 \mu$, between them on the valve mantle short, rib-like wall thickenings which end on one side at the valve edge, on the other side at the raphe, about 16 in $10 \mu$. Secondary pseudosepta not present. Transapical striae about 16 in $10 \mu$, coarsely punctate; puncta in quincunx, so that oblique rows are formed; oblique rows more widely separated than the transapical rows, about 7 in $10 \mu$. Raphe marginal, inner canal openings 8-9 in $10 \mu$. Septa with 4-5 crossbars in $10 \mu$, each crossbar connected with the septum by a suture at both ends."

Type locality. Polycystinen-Gestein der Insel Nankoori, Frauenseld (Nicobar Island).

Stratigraphic occurrences. Common to frequent in middle Miocene $C$. nicobarica Zone (NPD5A), although it rarely occurs in older horizons. Species last occurs in the lower part of Denticulopsis praedimorpha Zone (NPD5B), which overlies the $C$. nicobarica Zone.

Observations. Copulae are open with both sides perforated by a row of puncta, 13-14 in $10 \mu$ m (Plate 5, Figs. 1A-4B, 6-7). ${ }^{3}$ Both valve face and mantle are furnished with coarse areolation. The areolae are composed of large circular puncta occluded by cross-shaped rotae (Plate 5, Figs. 8-9). They are arranged in transapical rows, 14-17 in $10 \mu \mathrm{m}$. On the valve face, the areolae are in quincunx pattern to form oblique rows, $12-14$ in $10 \mu \mathrm{m}$, whereas in addition to transapical rows, those of the mantle also form two longitudinal rows (Plate 5, Figs. 3A-4B). The inner space is subdivided by primary pseudosepta with crossbars at their bases (Plate 5, Figs. 5A-B), 4-5 in $10 \mu \mathrm{m}$. Marginal ribs are situated between transapical rows of mantle except at the positions where primary pseudosepta are located. The ribs are variable in length; some are very short but others are long enough to reach the valve face (Plate 5, Figs. 5a-b). In an extreme, but uncommon case (Plate 5, Figs. 2a-b), the ribs extend to the valve center from both sides forming a secondary pseudoseptum. A raphe, a slit composed of two branches (Plate 5, Fig. 8), is located along one edge of the valve face, extending to the near apices. The raphe canal is a rounded tube with broad fibulae and circular portulae, $8-9$ in $10 \mu \mathrm{m}$ or about two between each two pseudosepta.

Remarks. In the above cited description of Simonsen and Kanaya (1961), they interpreted "crossbar" as belonging to a septum. But that interpretation was retracted by Simonsen (1979), and he clarified the crossbar as a part of the pseudoseptum. The same clarification is applicable to similar structures in Denticulopsis and Neodenticula.

Although $C$. nicobarica does not bear secondary pseudosepta in general, occasionally rudimentary ones are irregularly positioned or interrupt the middle of the valve face. This feature was also noticed by Grunow (1868) in the original description of the species as "mit bisweilen unterbrochenen order fehlenden Rippen." We consider this feature common and unique to most species of Crucidenticula; therefore,

\footnotetext{
${ }^{3}$ Uppercase letters in plate figure numbers in text and plate captions refer to the same lowercase letters on plate labels.
} 
the presence or absence of secondary pseudosepta cannot be used for specific or intraspecific differentiations of the genus. For instance, Maruyama (1984) considered specimens with such secondary pseudosepta as a possible variety of the species, but we disagree with that interpretation.

Schrader (1976) suggested that this species evolved from Nitzschia maleinterpretaria Schrader (1976, p. 634, pl. 2, figs. 9, 11-19, 21, 24) in the Antarctic region. Barron (in press, a,b) observed both species in the eastern Tropical Pacific and dated their age ranges as 18.8-15.6 Ma for $N$. maleinterpretaria and 17.5-13.2 Ma for D. nicobarica. $N$. maleinterpretaria resembles $C$. nicobarica but differs by the absence of pseudosepta according to Schrader (1976), although to us the species looks quite similar to C. kanayae. Anyway, the stratigraphic and morphologic similarities of the two species might indicate that they are closely related phylogenetically.

\section{Crucidenticula paranicobarica Akiba and Yanagisawa n. sp.} (Plate 2, Figs. 8-14)

Description. In girdle view, frustule is rectangular with rounded corners, 5-8 $\mu \mathrm{m}$ in depth. Valve is linear to linear-elliptical, almost flat, $18-29 \mu \mathrm{m}$ long, $2.5-4.5 \mu \mathrm{m}$ wide. Apical axis of some specimens is slightly heteropolar. Valve face is punctate, usually sporadically except for one apically arranged marginal row of puncta, 14 puncta in $10 \mu \mathrm{m}$. Transapical striae, if present, are made from puncta that are not arranged in clear quincunx, about 14 in $10 \mu \mathrm{m}$. Pseudosepta have crossbars, 3-4 in $10 \mu \mathrm{m}$; some pseudosepta are slightly oblique to transapical axis and not always equally spaced. Secondary pseudosepta are absent. Marginal ribs are short but conspicuous and numerous, about 14 in $10 \mu \mathrm{m}, 2-6$ between each two pseudosepta. Raphe is marginal.

Holotype. Plate 2, Figure 10 from Sample JDS-4685, the Masuporo Formation of the Tenpoku Area, northern Hokkaido, slide No. $\mathrm{Zu} \mathrm{3/11} \mathrm{deposited} \mathrm{in} \mathrm{the} \mathrm{Hustedt} \mathrm{Collection,} \mathrm{Bremerhaven,} \mathrm{West} \mathrm{Ger-}$ many, $28 \mu \mathrm{m}$ in length, $4 \mu \mathrm{m}$ in width.

Paratype. Plate 2, Figure 12 from Sample JDS- 4686 from the same stratum as above, slide No. JDS-4686(1) deposited in the Central Technical Laboratory of JAPEX, Tokyo, frustule in girdle view, $25 \mu \mathrm{m}$ in length, $8 \mu \mathrm{m}$ in depth.

Stratigraphic occurrence. Rare in lower middle Miocene Denticulopsis lauta Zone (NPD4A).

Remarks. This new species resembles $C$. nicobarica and $C$. ikebei n. sp., but differs from the former by its sporadic presence and by the irregular arrangement of puncta, and from the latter by its slender valve. This new specific name was originally coined in a preliminary description by Seiich Komura, the senior author's colleague, but was combined with an unpublished different generic name. He has kindly allowed us to use this specific name for this new form. No SEM observation has been made to date.

Crucidenticula punctata (Schrader) Akiba and Yanagisawa, n. comb. et emend.

(Plate 1, Figs. 10-12; Plate 4, Figs. 1-9)

Basionym. Denticula punctata Schrader, 1973a, p. 705 , pl. 1 , figs. 25-30, not pl. 3, figs. 16-17.

Synonym. Denticula punctata Schrader, Schrader, 1973b, p. 420 , pl. 1, fig. 19; Denticulopsis punctata (Schrader) Simonsen, 1979, p. 65; Denticulopsis punctata f. hustedtii Schrader, 1973a, p. 705, pl. 1, figs. 23-24; Denticula punctata f. hustedtii (Schrader) Simonsen, 1979, p. 65 ; Denticula punctata var. hustedtii Schrader, 1973 b, p. 420 , pl. 1 , fig. 18; Barron, 1980a, pl. 1, fig. 29.

Type locality. DSDP Leg 18, Sample $173-21-3$, 55-56 cm, northeastern Pacific, off northern California.

Stratigraphic occurrence. Rare in upper middle Miocene Denticulopsis praedimorpha Zone (NPD5B). Also rare in underlying horizons, making its real first occurrence difficult to recognize.

Observations. Specimens are identical to "D. punctata f. hustedtii (Schrader) Simonsen." The cingulum consists of a copula and at least two pleurae (Plate 4, Figs. 1A-4). The copula is open and perforated by a row of puncta (Plate 4, Figs. 2-3). The pleurae are open and smooth, the first one narrow and the second one broad (Plate 4, Figs. 5-7), each with varying degree of development. Generally, both valve face and mantle are densely areolated. Both transapical and apical rows of areolae are discernible on valve mantle (Plate 4, Figs. 1-4). The areolae are occluded by cross-shaped rotae (Plate 4, Fig. 6). The raphe slit is divided at its center (Plate 4, Fig. 8). The portulae are circular, about two between each two primary pseudosepta (Plate 4, Fig. 7).

Remarks. This species is similar to C. kanayae n. sp., but is distinguished by finer transapical striae, linear-elliptical valve outlines, and more frequent secondary or rudimentary pseudosepta. It is easily distinguished from $C$. nicobarica by its larger size.

"Denticula punctata f. hustedtii" (or "D. punctata var. hustedtii") is said to be distinguished from this species by the presence of secondary pseudosepta (Schrader, 1973a, b), but the holotype specimen of Crucidenticula punctata also has several secondary or rudimentary pseudosepta between primary pseudosepta, although these are not always regularly spaced. There is, therefore, no reason to retain Denticula punctata $\mathrm{f}$. hustedtii as a distinct taxon. Two specimens illustrated here (Plate 1, Figs. 11-12) are seemingly typical of this species, and careful examination makes it clear that they have several rudimentary pseudosepta. Another specimen (Plate 1, Fig. 10) might be typical of " $D$. punctata $\mathrm{f}$. hustedtii;" however, many specimens are intermediate between those illustrated here, emphasizing a lack of a clear-cut distinction between this species and " $D$. punctata $\mathrm{f}$. hustedtii."

\section{Denticula norwegica Schrader}

(Plate 2, Figs. 15-21; Plate 6, Figs. 1-9)

Schrader and Fenner, 1976, p. 978, pl. 1, fig. 38.

Synonym. Denticula punctata Schrader, Schrader, 1973a, pl. 3, figs. 16-17; Denticulopsis norvegica (Schrader) Simonsen, 1979, p. 65. Sea.

Type locality. Sample 338-10,CC from DSDP Leg 38, Norwegian

Stratigraphic occurrence. Rare in lower Miocene Crucidenticula kanayae Zone (NPD3A) and Denticulopsis praelauta Zone (NPD3B).

Observations. Variations in the dimensions of this species are more pronounced than those outlined in the original description (length, 35-64 $\mu \mathrm{m}$; width 6-15 $\mu \mathrm{m}$; 3-5 pseudosepta in $10 \mu \mathrm{m} ; 12-18$ transapical striae in $10 \mu \mathrm{m} ; 10-16$ punctae in $10 \mu \mathrm{m}$ ) (Plate 2, Figs. 15-21). The primary pseudosepta have no distinct crossbars (Plate 6, Fig. 5). Marginal ribs are numerous but less conspicuous, and in some instances form secondary or rudimentary pseudosepta (Plate 6, Fig. 6). Near the valve ends, peculiar siliceous bars cross from one side to the other (Plate 6, Figs. 2-9). The areolae are very conspicuous and circular to transapically elongated quadrangular with finely perforated cribra (Plate 6, Fig. 8). The raphe slit is divided into two portions, interrupted at its center (Plate 6, Fig. 1). The portulae are circular, two between each two primary pseudosepta (Plate 6, Fig. 6). The portula is larger and apically elongate where the raphe slit is divided (Plate 6, Fig. 5).

Remarks. The valve outline of this species is unique and similar to previously mentioned Crucidenticula species in that it has very conspicuous areolae and numerous marginal ribs. However, our SEM observations, in particular, revealed several peculiar structures not recognized in Crucidenticula species. Finely perforated cribra of areolae and siliceous bars at the valve ends are never present in the Crucidenticula species examined. The species was transferred by Simonsen (1979) into Denticulopsis, which is subdivided into three genera in this chapter. Although, of the three, this species most closely resembles Crucidenticula and has common morphologic features with neither Denticulopsis emend. nor Neodenticula, we hesitate to include it in Crucidenticula because some of its structures are peculiar, and at present we are not certain of its precise systematic position. Therefore, we list this species by its original generic name.

\section{Denticulopsis Simonsen emend. Akiba and Yanagisawa}

Emended description. Frustule is rectangular with rounded corners in girdle view. All species probably form chains by contact of valve faces. Cingulum consists of a copula and three pleurae. Copula is open, or closed in some species, smooth or perforated by a row of puncta. Pleurae are open and smooth. Valve is linear to elliptical with broadly rounded apices and relatively high mantle. Primary pseudosepta broadened in apical direction and mostly with crossbars. Secondary pseudosepta often present. Marginal ribs present between pseudosepta in most species, one between each two pseudosepta and secondary pseudosepta. Either valve face or mantle or both have areolation, consisting of fine puncta arranged in multiple transapical striae between pseudosepta. In some species, areolation consists of outer membrane finely perforated and chamberlike inner puncta. Raphe is marginal, along the edge of valve face, two raphes of a frustule on opposing 
margins. Raphe slit is divided into two branches. Raphe canal has circular portulae, one between each two pseudosepta and/or secondary pseudosepta. All species are marine and extinct, possibly planktonic.

Type species. Denticulopsis hustedtii (Simonsen and Kanaya) Simonsen, 1979, p. 64

Remarks. This genus, as defined by Simonsen $(1979$, p. 63$)$, is emended here as above to exclude two groups of species previously included in this genus; those represented by $D$. nicobarica and $D$. kamtschatica are both now transferred to new genera, Crucidenticula and Neodenticula, respectively.

Denticulopsis hustedtii (Simonsen and Kanaya) Simonsen (Plate 17, Figs. 4-5, 7-23; Plate 18, Figs. 1-10; Plate 19, Figs. 1-5)

Simonsen, 1979, p. 64; Maruyama, 1984, pl. 12, figs. 7-8, 9a-b; pl. 13, figs. 1a-6; pl. 16, figs. 1-6.

Synonym: Denticula hustedtii Simonsen and Kanaya, 1961, p. 501, pl. 1, figs. 19-25; Denticula lauta Grunow, Kanaya, 1959, p. 112, in part, pl. 10, figs. 10-14.

Type locality. Sample No. 23 from Del Monte, Monterey County, California.

Stratigraphic occurrence. Common to abundant in an interval from middle Miocene Crucidenticula nicobarica Zone (NPD5A) through upper upper Miocene Denticulopsis katayamae Zone (NPD6A). It also occurs very sporadically in middle Miocene Denticulopsis hyalina Zone (NPD4B) and also occurs sporadically in $T$. schraderi Zone (NPD6B).

Observations. The cingulum is composed of a copula and three pleurae (Plate 19, Figs. 1-3). The copula is generally open (Plate 18, Fig. 10), but in some specimens closed copulae occur (Plate 17, Fig. 20). The pleurae are open and smooth, the first and third ones narrow and the second one broad (Plate 19, Figs. 2-3). The secondary pseudosepta are well developed (Plate 18, Figs. 4A-B). The marginal ribs are present (Plate 17, Fig. 14), although they are sometimes short and hardly discernible (Plate 17, Fig. 12). The areolae are sparser on valve face than on valve mantle (Plate 19, Fig. 2).

The specimen shown in Plate 19, Figures 4-5 was probably caught in the process of cell division. The right valve with a copula and three pleurae may be a epivalve before cell division and the left, with a copula and two pleurae, a hypovalve. Two new hypovalves are seen through cingulum of the epivalves.

Remarks. Well-developed secondary pseudosepta characterize this species, as well as D. katayamae, but this species differs from $D$. katayamae mainly by the presence of dense areolae on valve face.

The valve of this species is variable in shape and in size (Plate 17, Figs. 4-5, 9-14, 21), and by further studies it might be possible to recognize several stratigraphically limited distinct morphotypes. Maruyama (1984) recognized a form with a short and lanceolate valve that is limited to only part of the Thalassiosira yabei Zone (NPD5C).

\section{Denticulopsis dimorpha (Schrader) Simonsen}

(Plate 15, figs. 1-25; Plate 16, Figs. 1-11)

Simonsen, 1979, p. 64; Akiba, 1982b, p. 42, pl. 1, figs. 1-8; Maruyama, 1984 , pl. 15 , figs. $8-11$; pl. 18 , figs. $12-34$; pl. 20 , figs. $1-8$. Synonym. Denticula dimorpha Schrader, 1973a, p. 704, pl. 1, figs. $37-46$, in part.

Original description. Schrader, 1973a, p. 704 , pl. 1, figs. $37-46$ as Denticula dimorpha Schrader; "Valves linear-elliptical with bluntly rounded ends, 15-28 $\mu$ long, 4-8 $\mu$ wide in valve view, 8-10 $\mu$ wide in girdle view (complete cell). Pseudoseptae 4-6 in $10 \mu$, no secondary pseudoseptae. Valve almost hyaline, structures at the margin, on margin 2-3 transapical striae in between the pseudoseptae, largely punctate, 10 transapical marginal striae in $10 \mu$. Raphe marginal. At both poles of the septae on one side of the valve, a strongly silicified thickening which protrudes into the cell interior. The pseudoseptae of one valve penetrate through much of the half frustule and are easily separated from valves and found isolated. The opposite side of the intercalary bands possess one row of small punctae."

Type locality. Sample 173-20-3, 55-56 cm from DSDP Leg 18, northeastern Pacific, off northern California.

Stratigraphic occurrence. Common to abundant in upper Miocene Denticulopsis dimorpha Zone (NPDSD). Its total range defines the zone.

Observations. The copula is open or closed. The open one is narrow and perforated by a row of puncta (Plate 15, Figs. 21-22; Plate 16, Fig. 11). The closed copula is wide and smooth, and thickly silicified with serrated margin (Plate 15, Figs. 7-12, 19-20; Plate 16, Fig. 9). Pairs of inward extensions of the copula are connected to form crossrods or true septa (Plate 16, Figs. 6, 9). At least three pleurae, all of which are open and smooth, are recognized in a frustule (Plate 16, Fig. 8). Both valve face and mantle have distinct areolations composed of either fine puncta (Plate 15, Figs. 16-18, 23-25) or outer, finely perforated wall and inner chamberlike large puncta (Plate 15, Figs. 5-6, 13-15; Plate 16, Fig. 7). The density of areolation on valve face is almost the same as on the mantle. (Plate 16, Figs. 1-3). No secondary pseudosepta are present. The primary pseudosepta have either very low and indistinct crossbars, or lack them altogether (Plate 16, Fig. 10). The valve with very low crossbars possibly contacts with an open copula, whereas the valve without crossbars contacts with a closed copula (Plate 16, Fig. 5).

Remarks. The original description is erroneous in that the valve face is hyaline (Akiba, 1979, 1982b; Maruyama, 1984). According to our observations, especially by SEM, the valve has conspicuous transapical striae. We are under the impression that Schrader (1973a) regards an isolated closed copula with crossrods as the valve itself. However, perhaps the isolated valves of this species as well as those of $D$. praedimorpha were confused with those of $D$. lauta by Schrader (1973a,b) and others (e.g., Koizumi, 1977; Barron, 1980a), causing disparate recognition of stratigraphic ranges of all three species and hence different diatom zonal subdivisions for each (see Akiba, this volume for more details).

$D$. dimorpha is similar to $D$. lauta and to $D$. praedimorpha, but is distinguished from them by several unique structures. The most diagnostic structure is a closed copula with crossrods, a feature not present in the other two species. Its valve resembles those of $D$. lauta and $D$. praedimorpha, but is characterized by the absence or very poor development of crossbars of pseudosepta. In contrast, pseudosepta of $D$. lauta are furnished with well-developed crossbars and those of $D$. praedimorpha with only partially developed crossbars. Valves with very coarse areolae, covered with a finely perforated outer wall are sometimes observed in $D$. dimorpha, but never in the other two species. At present, valves with poorly developed crossbars are difficult to distinguish from those of $D$. praedimorpha, but it seems to us that $D$. dimorpha had shorter marginal ribs than the latter.

\section{Denticulopsis hyalina (Schrader) Simonsen}

(Plate 10, Figs. 1-16; Plate 11, Figs. 1-10; Plate 12, Figs. 1-5)

Simonsen, 1979, p. 64; Maruyama, 1984, pl. 13, figs. 7-10; pl. 16, figs. 7-8.

Synonym. Denticula hyalina Schrader, 1973a, p. 704, pl. 1, figs. 12-22; 1973b, p. 418, pl. 1, figs. 10, 22; Barron, 1980a, pl. 1, fig. 12; Koizumi, 1975, pl. 1, figs. 21-26; Denticula hyalina var. hustedtii Schrader, 1973b, pl. 1, figs. 9, 21; Denticula lauta Bailey, Schrader, 1973b, pl. 1 , fig. 20.

Type locality. DSDP Leg 18, Sample $173-26-4,55-56 \mathrm{~cm}$, northeastern Pacific, off northern California.

Stratigraphic occurrence. Common to abundant through middle Miocene Denticulopsis hyalina Zone (NPD4B), and rare in overlying sequences until upper Miocene Rouxia californica Zone (NPD7A). Occurs frequently in upper Miocene Thalassionema schraderi Zone (NPD6B).

Observations. The cingulum is composed of a copula and at least two pleurae (Plate 12, Fig. 1). The copula is open and smooth (Plate 10, Figs. 13-16; Plate 12, Figs. 1). The pleurae are also open and smooth, the first one narrow and the second broad (Plate 11, Fig. 1). The valve is thickly silicified with a relatively broad deck (Plate 11, Fig. 3). Secondary pseudosepta are absent, whereas marginal ribs are developed (Plate 10, Figs. 7-10). The valve face is almost hyaline (Plate 10, Figs. 7-10; Plate 11, Figs. 4, 8). A punctate triangular area lies between each two pseudosepta near raphe-bearing margin, and a hyaline triangular area of strong silicification is located near the opposite margin (Plate 11, Figs. 1, 8). The mantle areolae are composed of an outer, very finely perforated wall and inner, chamberlike large puncta (Plate 11 , Figs. 2,5 ). The outer thin wall is often dissolved in poorly preserved specimens (Plate 11, Figs. 8-9) or not discernible by LM (Plate 10, Figs. 1-6).

Remarks. This species is characterized by an almost hyaline valve face and very high mantle with very coarse areolae, which are submicroscopically double-layered. It is similar to $D$. miocenica, but is generally distinguished from the latter by its smaller size. It is also distin- 
guished from $D$. katayamae by the absence of secondary pseudosepta and the finer punctation of outer wall of mantle areolae.

\section{Denticulopsis katayamae Maruyama}

(Plate 17, Figs. 1-3, 6; Plate 19, Figs. 6-9; Plate 20, Figs. 1-7)

Description. Maruyama, 1984, p. 158, pl. 12, figs. 1a-b, 2-6; pl. 17, figs. 1-32; Schrader, 1973b, p. 418 as Denticula hyalina var. hustedtii Schrader.

Stratigraphic occurrence. Common to abundant in upper Miocene Denticulopsis katayamae Zone (NPD6A) and characteristic of the zone. The first occurrence of this species is recognized in the middle part of the Denticulopsis dimorpha Zone (NPD5D, Fig. 1), and its last occurrence is near the top of the overlying $D$. katayamae Zone.

Observations. The cingulum is composed of a copula and at least two pleurae (Plate 19, Fig. 7). The copula and pleurae are open and smooth. The secondary pseudosepta and marginal ribs are well developed (Plate 17, Fig. 1; Plate 20, Fig. 7). The valve face is almost hyaline (Plate 17, Figs. 1-3; Plate 20, Figs. 2-3). A punctate triangular area lies between each of two pseudosepta near raphe-bearing margin (Plate 19, Fig. 9), whereas a hyaline thickly silicified triangular area is located near the opposite margin (Plate 19, Fig. 8). The mantle areolae are composed of an outer, finely perforated wall and inner, chamberlike large puncta (Plate 20, Figs. 4-5). The raphe canal is a tube, circular in cross section (Plate 20, Fig. 6). The raphe slit is divided into two portions, interrupted at its center (Plate 20, Fig. 3).

Remarks. This species is very similar to $D$. hustedtii in the presence of secondary pseudosepta, but differs from it in having the hyaline valve face and double-layered areolation of mantle. Conversely it also resembles $D$. hyalina in that both species have a hyaline valve face and double-layered areolation on mantle, but differs from the latter in the presence of secondary pseudosepta and coarser punctation of outer wall of mantle areolae. Because of the absence of easily discernible diagnostic features, distinction of this species from $D$. hustedtii in girdle view is difficult using $\mathrm{LM}$.

This species was described correctly by Schrader (1973b) as Denticula hyalina var. hustedtii except that he perhaps confused its valve mantle with that of $D$. hyalina. His holotype specimen of the taxon (Schrader, 1973b, pl. 1, fig. 9) does not fit his description, namely it lacks secondary pseudosepta. Accordingly, his specimen is D. hyalina, and Schrader's (1973b) taxon is invalid.

LM observations of D. katayamae, $D$. hustedtii, and $D$. hyalina and also their stratigraphic occurrences (Fig. 1) suggest that D. katayamae might have evolved from $D$. hustedtii as suggested by Maruyama (1984), but also that $D$. katayamae might have developed from $D$. hyalina as suggested by Schrader (1973b), because the two species have several morphologic features in common.

\section{Denticulopsis lauta (Bailey) Simonsen}

(Plate 7, Figs. 16-29; Plate 9, Figs. 1-9)

Simonsen, 1979, p. 64.

Synonym. Denticula? lauta Bailey, 1854, p. 9, figs. 1-2; Denticula lauta Bailey, Simonsen and Kanaya, 1961, p. 500, in part, pl. 1, figs. $1-5$, not 6-10.

Type locality. Suisan Bay, California (the Tice Shale exposed in Pinole, south side of San Pablo Bay; after Hanna, 1932, and Simonsen and Kanaya, 1961).

Stratigraphic occurrences. Common to abundant from lower middle Miocene Denticulopsis lauta Zone (NPD4A) through the lower part of its overlying $D$. hyalina Zone (NPD4B). It last occurs in lower part of Crucidenticula nicobarica Zone (NPD5A), and its first occurrence defines the base of the $D$. lauta Zone (Fig. 1).

Observations. The frustules form chains by contact with valve faces (Plate 9, Fig. 7). The cingulum is composed of a copula and three pleurae in general. The copula is open and smooth (Plate 7, Fig. 17; Plate 9, Fig. 2), or sometimes perforated by a row of puncta (Plate 9, Fig. 3). Secondary pseudosepta are absent, but apical pseudosepta with two apical costae are present (Plate 9, Fig. 4). Crossbars of pseudosepta are well developed (Plate 7, Fig. 26; Plate 9, Figs. 4a-b). The marginal ribs are distinct (Plate 7, Figs. 23-25; Plate 9, Fig. 7). The areolation is sparser on the valve face than on the mantle (Plate 9, Fig. 8). The raphe slit is divided into two branches at its center (Plate 9, Figs. 1, 7).

Remarks. This species differs from $D$. hustedtii and $D$. katayamae by the absence of secondary pseudosepta, and the presence of conspic- uous marginal ribs distinguishes it from $D$. praelauta. Areolation patterns differ between $D$. lauta, D. hyalina, and $D$. miocaenica. This species is easily distinguished from $D$. praedimorpha and $D$. dimorpha by shape and structure of the copula. D. lauta always has open copulae, whereas the latter two possess strongly silicified closed copulae as well as open ones. The valve structures of all three species are similar, but $D$. lauta has well-developed crossbars of pseudosepta, whereas pseudosepta of the other two species are only partially or incompletely developed.

The last paragraph of the description of $D$. lauta by Simonsen and Kanaya (1961, p. 501) should be omitted, because it describes attributes of $D$. praedimorpha.

\section{Denticulopsis miocenica (Schrader) Simonsen \\ (Plate 10, Figs. 17-23; Plate 12, Figs. 6-9)}

Simonsen, 1979, p. 65.

Synonym. Denticula miocenica Schrader, 1973a, p. 705, pl. 2, figs. 26-28, not pl. 3, figs. 16-17; 1937b, p. 419, pl. 1, figs. 14-15.

Type locality. Sample $173-29-2,57-58 \mathrm{~cm}$ of DSDP Leg 18, northeastern Pacific, off northern California.

Stratigraphic occurrence. Rare in middle Miocene Denticulopsis hyalina Zone (NPD4B)

Observations. The valve is broad-elliptical to linear-elliptical with a very broad deck and well-developed crossbars, which almost contact adjacent ones to form rounded foramen or "inner opening" sensu Schrader (1973a) (Plate 10, Fig. 20; Plate 12, Fig. 6). There are two distinct morphotypes: one has a hyaline valve face and marginal raphe (Plate 10, Figs. 22-23; Plate 12, Figs. 6-9), and the other has a coarsely areolated valve face and central raphe (Plate 10, Figs. 20-21). The former type occurs more frequently than the latter. Valve mantles of both types are similarly coarsely areolated. Other features of this species are almost the same as those of D. hyalina (Plate 12, Figs. 7-9).

Remarks. Taxonomic status of this species is problematic. Its general morphologic characteristics are almost the same as those of $D$. hyalina. Reported differences between the two are the valve size and the foramen shape, but these features might be continuous from one extreme to another, although no detailed biometric studies are attempted at present.

A peculiar feature recognized in $D$. miocenica is that it is represented by two morphotypes as noticed by Schrader (1973a). It is our impression that the type with a hyaline valve face is only a larger specimen of $D$. hyalina. The other type with an areolated valve face and central raphe is identical to the holotype specimen of this species, and also seemingly conspecific to Katahiraia aspera Komura (Komura, 1976, p. 385 , text-fig. 5; plate 41 , figs. 1-5). Komura (1976) proposed his new genus Katahiraia with three new species, the genus characterized by canal raphe positioned in the center of valve and coarse areolation on valve face. Both morphotypes of $D$. miocenica occur exclusively in assemblages composed predominantly of $D$. hyalina and are virtually absent in other assemblages. We, therefore, suspect that $D$. hyalina and $D$, miocenica might be conspecific and also that the latter might represent an auxospore of the former.

\section{Denticulopsis praedimorpha Barron ex Akiba}

(Plate 13, Figs. 1-28; Plate 14, Figs. 1-12)

Akiba, 1982b, p. 46, text-fig. 4; pl. 11, figs. 9a-27b; Maruyama, 1984, pl. 15 , figs. $1-7$; pl. 18 , figs. $1-11$; pl. 19, figs. $1-15$.

Synonym. Denticula lauta Bailey, Kanaya, 1959, p. 112, in part, pl. 10, figs. 7-9, 16, not 10a-15; Simonsen and Kanaya, 1961, p. 500, in part, pl. 1, figs. 6-10, not 1-5; Denticula dimorpha Schrader, 1973a, p. 704, in part; Denticula praedimorpha Akiba ex Barron, 1980a, p. 672 , pl. 1, figs. $18-20$, nom. invalid; Denticulopsis praedimorpha (Akiba) Barron, nom. invalid, Barron, 1981, p. 529, pl. 4, figs. 8-10; Akiba et al., 1982, pl. 3, figs. 58-62.

Type locality. Sample 438A-65-1, 136-137 cm of DSDP Leg 57, northwestern Pacific, off northeastern Honshu, Japan; upper middle Miocene.

Stratigraphic occurrence. Common to abundant in $D$. praedimorpha Zone (NPD5B). The total range of this species defines the zone.

Observations. The copula is open or closed. The open copula (type $\mathrm{Co}$ ) is narrow and perforated by a row of puncta (Plate 13, Figs. 26-28; Plate 14, Fig. 1). The closed copula is wide and smooth, and thickly silicified with margin either serrated (type Ccr; Plate 14, Fig. 5), or smooth (type Ccm; Plate 14, Fig. 6). At least three pleurae are recog- 
nized; each is open and smooth (Plate 14, Fig. 1). In addition, another special open band combines with the copula (Plate 14, Figs. 2-3). Secondary pseudosepta are not present. The pseudosepta have either very low and indistinct crossbars (Plate 13, Figs. 16, 19-21; Plate 14, Fig. 8 ) or high and short crossbars near center (Plate 13, Figs. 12-15; Plate 14, Fig. 4). The valve with very low crossbars combines with open copula (Plate 14, Fig. 9), whereas the valve with high crossbars combines with closed copula (Plate 13, Figs. 8-9, 11, 17; Plate 14, Fig. 7). The areolae on the valve faces are almost the same in density as those on the mantle (Plate 14, Fig. 1).

Remarks. This species closely resembles both $D$. dimorph $a$ and $D$. lauta among the other Denticulopsis species, in that all lack secondary pseudosepta and all have valve faces with dense transapical striae. $D$. praedimorpha however, is, distinguished from other two species by partially developed crossbars of pseudosepta and a unique structure of closed copula. See also comments under $D$. dimorpha.

The original description of Akiba (1982b) should be corrected in that this species lacks secondary pseudosepta, and in that the two types of valves, "shallower" and "deeper," are in reality of the same depth, as was pointed out by Maruyama (1984). Different degrees of development of crossbars make this species basically heterovalvate, as previously described. The depths of the two kinds of theca differ conspicuously from each other by narrower-open and broader-closed copulae, not by their valve depth.

Although the three types of copulae $(\mathrm{Co}, \mathrm{Ccr}$, and $\mathrm{Ccm})$ mentioned above might theoretically form nine $(3 \times 3)$ combinations in the frustule, we identified only four combinations: $\mathrm{Co} / \mathrm{Ccr}$ (Plate 14, Fig. 12), $\mathrm{Co} / \mathrm{Ccm}, \mathrm{Ccr} / \mathrm{Ccm}$ (Plate 14, Fig. 2), and $\mathrm{Ccm} / \mathrm{Ccm}$ (Plate 14, Fig. 11).

Denticula? sp. of Kanaya (1959) is evidently a closed-copula variety of this species. His records of this species made it possible to subdivide his "Coscinodiscus yabei assemblage" into a Thalassiosira yabei Zone and Denticulopsis praedimorpha Zone (Akiba, this volume).

\section{Denticulopsis praelauta Akiba and Koizumi}

(Plate 7, Figs. 1-15; Plate 8, Figs. 1-9)

Akiba, this volume.

Synonym. ?Denticula aff. kamtschatica Zabelina, Schrader, 1976, p. 632 , pl. 4, fig. 18; Denticula sp. cf. lauta Bailey, Barron, 1980a, p. 672 , pl. 1, figs. 13-14; Denticulopsis sp. A, Akiba et al., 1982, pl. 3, figs. 41-44.

Type locality. Sample 439-8-6, 49-52 cm of DSDP Leg 57, northwestern Pacific, off northeastern Honshu, Japan.

Stratigraphic occurrence. Common to abundant in lower Miocene D. praelauta Zone (NPD3B). The first occurrence of the species defines the base of the zone, and its last occurrence is observed in the lower part of the overlying D. lauta Zone (NPD4A).

Observations. The cingulum consists of a copula and probably three pleurae. The copula is either open and smooth (Plate 7, Fig. 14; Plate 8, Fig. 5) or open and perforated by a row of puncta (Plate 7, Fig. 13; Plate 8, Figs. 1-2, 4,6). The valve is linear with broadly rounded apices and a relatively high mantle. Secondary pseudosepta are absent, but one apical pseudoseptum is present at each apex (Plate 7, Figs. 1, 5, 7, 12; Plate 8, Figs. 4-5, 7). Marginal ribs either absent (Plate 7, Figs. 1-5) or only very poorly developed (Plate 7, Figs. 7-9). Areolation consists of fine puncta arranged in multiple transapical striae (Plate 8, Figs. 1-2, 8-9). Density of striae of the valve face is the same as that of the mantle. Raphe is marginal, along the edge of the valve face and mantle; the raphe slit separates into two branches at center (Plate 8, Fig. 9). Portulae are circular, one between each two pseudosepta (Plate 8, Fig. 7).

Remarks. This species resembles D. lauta, but is distinguished from the latter by the absence or very poor development of marginal ribs. It is perhaps an ancestral form of D. lauta and also may be the oldest representative of genus Denticulopsis.

\section{Neodenticula $\mathbf{n}$. gen.}

Description. In girdle view, frustule is rectangular with rounded corners (Fig. 2). All species form chains by contact of valve faces. Cingulum is a copula and three pleurae. The copula is open or closed in some species, smooth or with a row of very fine puncta. The valve is linear to linear-elliptical with broadly rounded apices and relatively low mantle. Primary pseudosepta have crossbars, but crossbars are sometimes missing; secondary pseudosepta are often present. Pseudosepta often branch at raphe-bearing margin. Valve face and mantle are areolated, with very fine puncta arranged in multiple transapical striae between the pseudosepta. Raphe is marginal, along the edge of the valve face, two raphes of a frustule on opposing margins. Raphe slit is continuous. Raphe canal has circular portulae, one between each two branches of pseudosepta. All species are marine, planktonic, mostly fossil.

Type species. Neodenticula kamtschatica (Zabelina) n. comb.

Remarks. This new genus resembles two genera, previously described, Crucidenticula n. gen. and Denticulopsis emend., but is clearly distinguished from them both morphologically and phylogenetically as follows.

1. One of the most characteristic features of this genus is structural asymmetry of valve. The asymmetry is caused by presence of marginal ribs only at raphe-bearing margin (Fig. 2). The marginal ribs are made by branching of pseudosepta or secondary pseudosepta. In the other two related genera, branching of the pseudosepta is not present and marginal ribs are symmetrically positioned at both valve margins.

2. Another conspicuous feature is very fine areolation on valve face and mantle, but this is generally difficult to recognize by LM. Areolation of Crucidenticula is very coarse, and that of Denticulopsis is intermediate between the two.

3. Raphe slit is continuous in this genus, but is divided into two branches in both Crucidenticula and Denticulopsis. The number and position of portulae, unique to each of the three genera, have been discussed previously in the Crucidenticula "Remarks" section.

4. Neodenticula probably belongs to a different lineage from that of the other two related genera on the basis of both its morphologic characteristics and its stratigraphic occurrences. The oldest species of the genus $N$. kamtschatica (Zabelina) n. comb. appears in the uppermost upper Miocene after most Denticulopsis and Crucidenticula species disappear (Fig. 1). Although Denticulopsis hyalina is rarely associated with $N$. kamtschatica in this horizon, it is unlikely that $D$. hyalina evolved into $N$. kamtschatica, because their morphologic differences are too great. Schrader (1973b) did, however, infer evolutionary relationships between the two species. If such evolution took place, it was accompanied by such drastic and contradictory changes as follows: disappearance of marginal ribs on the raphe-less valve margin and development of branched pseudosepta, reduction of coarse areolae on the valve mantle to fine areolae, and formation of fine areolae on hyaline valve face. On the other hand, $N$. kamtschatica accompanies at its earliest range a morphologically similar species, Nitzschia rolandii Schrader emend. Koizumi (Plate 21, Fig. 1-6) (Fig. 1). Morphologic differences between the two species are far less significant than those between $D$. hyalina and Neodenticula kamtschatica; namely, the only difference is the well-developed pseudosepta in N. kamtschatica. Neodenticula probably evolved from Nitschia rolandii, or from other closely related Nitzschia species, in the latest late Miocene.

\section{Neodenticula kamtschatica (Zabelina) Akiba and Yanagisawa n. comb.}

(Plate 21, Figs. 7-21; Plate 22, Figs. 1-12)

Basionym. Denticula kamtschatica Zabelina, 1934, p. 16, figs. 7-9. Synonym. Denticula kamtschatica Zabelina, Simonsen and Kanaya, 1961, p. 503, pl. 1, figs. 14-18; Sheshukova-Poretzkaya, 1967, p. 300 , pl. 47 , figs. $9 a-b$; plate 48 , figs. $4 a-e$; Koizumi, 1968, p. 213 , plate 34 , figs. $7-10 ; 1973$ b, p. 832 , pl. 5 , figs. 1a-e; Schrader, 1973 b, p. 418 , pl. 1, figs. 7-8; Barron, 1980 a, p. 672 , pl. 1, figs. 5-8; Denticula seminae var. fossilis Schrader, 1973b, pl. 1, figs. 5-6; Denticulopsis kamtschatica (Zabelina) Simonsen, 1979, p. 64; Akiba et al., 1982 , pl. 3, figs. 66-68; Denticula kamtschatica Zabelina emend. Koizumi, 1980 , p. 396 , pl. 2 , figs. $1-10$.

Original description. Zabelina, 1934, in Russian translated by Constance Sancetta; "Valve obovate to elongate-elliptical with strongly pronounced transverse costae and presence of a keel-like formation on valve margin with clearly perceptible keel puncta, more or less closely set than costae. Striae, set between costae, inconspicuous. In girdle view cell is of rectangular form. Length 9-24 $\mu$, width 4-6 $\mu, 4-8$ costae in $10 \mu, 10-11$ keel puncta in $10 \mu . "$

Type locality. Tertiary system of Kamchatka.

Stratigraphic occurrence. Common to abundant in an interval from the $N$. kamtschatica Zone (NPD7B) to the N. koizumii-N. kamtschatica Zone (NPD8), although it occurs very sporadically in the underly- 
ing Rouxia californica Zone (NPD7A). The last occurrence of the species defines the top of the $N$. koizumii-N. kamtschatica Zone (NPD8).

Observations. The cingulum is composed of a copula and at least three pleurae (Plate 22, Figs. 1, 8). The copula is either perforated by a row of very fine puncta (Plate 22, Figs. 1, 8), or is smooth (Plate 22, Figs. 7, 12). The pleurae are mostly smooth, but the third one is perforated (Plate 22, Fig. 8). Primary pseudosepta have crossbars (Plate 22, Fig. 1-2), although in many specimens the crossbars are either not conspicuous or are absent (Plate 22, Figs. 2-6). Secondary pseudosepta generally are not present. Marginal ribs, made by the branching of pseudosepta, are present at the raphe-bearing margin only. The density of transapical striae of the valve face is the same as that of valve mantle striae (Plate 22, Figs. 1, 10-11). The raphe slit is seemingly continuous (Plate 22, Figs. 10-11).

Remarks. The absence of secondary pseudosepta characterizes this species. In rare cases, secondary pseudosepta are observed (Plate 21, Fig. 21), but they are restricted to "only shortly before the ends" (Simonsen and Kanaya, 1961).

The number of pseudosepta per $10 \mu \mathrm{m}$ is variable (5-10). Simonsen and Kanaya (1961) give 5-6 for the number, and Koizumi (1980) emended that to 5-8, although the latter number is included in the dimension given by the original description (Zabelina, 1934; 4-8). Generally speaking, narrower valves have narrower pseudosepta and larger or wider ones have wider pseudosepta (See Plate 21). Specimens with narrower valves and pseudosepta resemble Nitzschia rolandii Schrader emend. Koizumi (Koizumi, 1980, p. 396, pl. 2, figs. 15-20; Plate 21, Figs. 1-6). Koizumi (1980) gives different ranges for the number of pseudosepta or costae of the two species (5-8 versus 10-12), but our observations show that the ranges overlap (5-10 versus 9-13). The possible diagnostic characteristics separating Neodenticula kamtschatica from Nitzschia rolandii may be the well-developed pseudosepta and marginal ribs, but this difference might reflect the degree of development. Clear distinctions between the two species are not always easy. Because of these similarities, we suspect that Neodenticula kamtschatica may have evolved from Nitzschia rolandii.

Neodenticula koizumii Akiba and Yanagisawa stat., nom. et comb. n. (Plate 21, Figs. 22-28; Plate 23, Figs. 1-12; Plate 24, Fig. 19)

Synonym. Denticula seminae Simonsen and Kanaya, Koizumi, 1973 b, p. 832 , in part, pl. 5, figs. 7-9, 10-13, not figs. 1-6; not Denticula seminae f. fossilis Koizumi ex Schrader, 1973a, p. 705, pl. 5, figs. 30, 37-38; not Denticula seminae var. fossilis Schrader, 1973b, p. 420 , pl. 1 , figs. $5-6$, nom. invalid.

Description. In girdle view, frustule is rectangular with rounded corners. Cingulum consists of a copula and at least two pleurae (Plate 23, Fig. 11), or is perforated by a row of very fine puncta (Plate 23, Fig. 1). Pleurae are open and smooth. Valve is linear to linear-elliptical with broadly rounded apices and relatively low mantle, 10-42 $\mu \mathrm{m}$ long and 3-6 $\mu \mathrm{m}$ wide, mostly $15-32 \mu \mathrm{m}$ long and $4.5-5 \mu \mathrm{m}$ wide. Pseudosepta, not always equally spaced with respect to each other, $2-4$ in $10 \mu \mathrm{m}$, are straight throughout valve face in transapical direction, broadened in apical direction forming crossbars (Plate 23, Figs. 4, 9-10), the latter sometimes inconspicuous or absent (Plate 23, Figs. 5-8). Secondary pseudosepta are present, straight throughout valve face in transapical direction, 1-3 between pseudosepta. Pseudosepta and secondary pseudosepta are equally spaced, usually $6-7$ in $10 \mu \mathrm{m}$, and 7-8 in $10 \mu \mathrm{m}$ in smaller and narrower specimens. Branching of pseudosepta and secondary pseudosepta very distinct at raphe-bearing margin (Plate 23, Figs. 4-7), and no marginal ribs are present at the other margin (Plate 23, Fig. 8). Transapical striae on both valve face and mantle are very fine, usually not discernible by LM, but clearly visible by SEM, and the density of striae on valve face is the same as that on mantle (Plate 23 , Figs. 1-8). Raphe is marginal, along the edge of valve face, and raphe slit is seemingly continuous (Plate 23, Figs. 1, 3). Raphe canal has circular portulae, one between each two branches of pseudosepta and secondary pseudosepta (Plate 23, Figs. 4, 7).

Holotype. Plate 21, Figure 28, Sample JDS-8629, Shiranuka Formation, Atsunai Area, eastern Hokkaido, slide No. Zu 3/23 deposited in Hustedt Collection, Bremerhaven, West Germany, $32 \mu \mathrm{m}$ long and $4.5 \mu \mathrm{m}$ wide.

Paratype. Plate 21, Figure 27, from the same sample as holotype, slide No. JDS-8629(b) deposited in Central Technical Laboratory of JAPEX, Tokyo, $20 \mu \mathrm{m}$ long and $4.5 \mu \mathrm{m}$ wide.
Stratigraphic occurrence. Common to abundant in an interval from the base of Pliocene $N$. koizumii-N. kamtschatica Zone (NPD8) through overlying $N$. koizumii (Zone NPD9). It also occurs sporadically in the uppermost part of the underlying $N$. kamtschatica Zone (NPD7B) and in the overlying Actinocyclus oculatus Zone (NPD10) and Rhizosolenia curvirostris Zone (NPD11). The first common occurrence of this species defines the base of the N. koizumii-N. kamtschatica Zone (NPD8).

Remarks. This species is similar to $N$. kamtschatica, but is easily distinguishable from the latter by the presence of secondary pseudosepta.

It differs from $N$. seminae in that pseudosepta and secondary pseudosepta near the apices are not curved but are parallel to the transapical axis and in that the branchings of pseudosepta and secondary pseudosepta at the raphe-bearing margin are very conspicuous. In addition, our SEM observations reveal that the density of areolae is also a diagnostic characteristic separating the two species; in N. koizumii, the areolae density is the same on the valve face and on the mantle, whereas it is much sparser on the valve face than on the mantle in $N$. seminae.

Previous taxonomic treatments of this species are both incomplete and misleading, as are those of Denticulopsis katayamae Maruyama. Schrader (1973b) correctly described its morphology as Denticula seminae var. fossilis. The holotype of the form (Schrader, 1973b, pl. 1, figs. 5-6), however, did not match his description; namely, it possesses no secondary pseudosepta and accordingly the type specimen is identical to $N$. kamtschatica. In addition, this species is not a variety of $N$. seminae as designated by Schrader (1973b), but a separate species with a distinct morphology and different stratigraphic distribution from $N$. seminae.

A form described and illustrated by Schrader (1973a) as Denticula seminae f. fossilis Koizumi is undoubtedly identical to Nitzschia rolandii Schrader emend. Koizumi. Schrader's (1973a) description is presumably based on a personal communication from Koizumi, because the same descriptive line appears in both Schrader (1973a) and Koizumi (1973b). Evidently "the reduction of secondary pseudosepta between the pseudosepta" was understood to be the absence of secondary pseudosepta. From his figures, however, it is clear that Koizumi (1973b) meant "fewer number of secondary pseudosepta" (Koizumi, 1973b, pl. 5, figs. 7-9, 10-13).

\section{Neodenticula seminae (Simonsen and Kanaya) Akiba and Yanagisawa n. comb. \\ (Plate 24, Figs. 1-11; Plate 26, Figs. 1-10)}

Basionym. Denticula seminae Simonsen and Kanaya, 1961, p. 503, pl. 1, figs. $26-30$.

Synonym. Denticula marina Semina, 1956, p. 82, figs. 1a-2b, nom. invalid; Denticulopsis seminae (Simonsen and Kanaya) Simonsen, 1979, p. 65.

Type locality. North Pacific Ocean (that of Denticula marina Semina).

Stratigraphic occurrence. Common to abundant in Quaternary to Recent. The first occurrence of this species might be somewhere in upper Pliocene, but that datum is not very convincing because of the previous taxonomic ambiguities between this species, $N$. koizumii and N. sp. A.

Observations. Frustules form long chains by contact with valve faces (Plate 24, Figs. 8, 10-11). Copulae observed are closed and smooth (Plate 24, Figs. 6-7; Plate 26, Figs. 7-8), although an open copula has been reported (Hasle, 1972, fig. 4). Pseudosepta have well-developed crossbars (Plate 24, Figs. 4-5; Plate 26, Figs. 1-3), but in some cases these are less conspicuous or absent (Hasle, 1972, fig. 8; Semina, 1981 , figs. 8, 14). Secondary pseudosepta are well developed and curved near the apices (Plate 26, Figs. 2, 10). Branching of pseudosepta and secondary pseudosepta is inconspicuous and only discernible by careful inspection. Both the valve face and mantle are generally furnished with transapical striae, even if not discernible by $\mathrm{LM}$, but they are sparser on the valve face than on the mantle (Plate 26, Figs. 4-6), as already shown by Semina (1981).

Remarks. This species resembles both $N$. koizumii and $N$. sp. A, but differs from these in having curved pseudosepta and secondary pseudosepta near apices and in lacking conspicuous branching of pseudosepta and secondary pseudosepta at raphe-bearing margin. This spe- 
cies is also distinguished from N. koizumii in that transapical striae of valve face are sparser than those of mantle.

There is a controversy regarding the presence of septa in this species. Simonsen (1979) clarified that crossbars of a septum in marine "Denticula" species sensu Simonsen and Kanaya (1961) are in fact basal thickenings of pseudosepta, and he mentioned that all species of Denticulopsis as defined by him lack septa. Semina (1981) and also Takano (1982), on the other hand, insisted that Neodenticula seminae has septa on its valve, but their interpretation may be erroneous, because a septum is a structure of the copula, not of the valve, as recommended by Anonymous (1975) and Ross and others (1979). It is our opinion that the copulae of this species have septa, although they are very narrow (Plate 26, Fig. 7), and that these fit to the deck of the valve, meeting crossbars of the pseudosepta (Plate 26, Fig. 1). The same arrangement might be true of all species of this genus and also of Crucidenticula and Denticulopsis emend.

\section{Neodenticula sp. A.}

(Plate 21, Figs. 29-31; Plate 24, Figs. 12-18; Plate 25, Figs. 1-7)

Description. Valve is broad-elliptical to elliptical, 6-21 $\mu \mathrm{m}$ long, 4.5-6.5 $\mu \mathrm{m}$ wide, with broadly rounded apices. Pseudosepta, 1-3 in $10 \mu \mathrm{m}$, are not always evenly spaced. Secondary pseudosepta are well developed, 1-3 between pseudosepta or near apices. Pseudosepta and secondary pseudosepta, which are equally spaced, 7-8 in $10 \mu \mathrm{m}$, parallel the transapical axis except for those near apices, which are outwardly concave. Marginal ribs made by branching of pseudosepta and secondary pseudosepta at the raphe-bearing margin are fairly conspicuous (Plate 24, Figs. 12, 18), 9-12 in $10 \mu \mathrm{m}$, but are missing at the other margin. Both the valve face and mantle are furnished with fine transapical striae, and those on the former are sparser than on the latter (Plate 25, Figs. 1-2).

Stratigraphic occurrence. Not well investigated until present, but this species may be common in lower Quaternary judging from its stratigraphic distribution determined in this investigation.

Remarks. This form is presumably an intermediate taxon, both morphologically and phylogenetically between $N$. koizumii and $N$. seminae. It is distinguished from the former by outwardly concave pseudosepta and secondary pseudosepta near the apices, and from the latter by easily discernible marginal ribs. Although some uncertainty remains because our present examination of it is very limited both geographically and stratigraphically, this form is probably a distinct species. On the other hand, the pattern of transapical striae on the valve face and mantle, features commonly recognized in both $N$. seminae and $N$. sp. A, suggest that this form may be included in $N$. seminae.

\section{TRANSFERS OF PLICATED COSCINODISCUS SPECIES TO GENUS THALASSIOSIRA}

R. Simonsen (pers. comm., 1980) suggested to the senior author that all plicated Coscinodiscus species previously described might belong to Thalassiosira. In the examination of a modern species, Coscinodiscus lacustris Grunow, the most familiar plicated Coscinodiscus species for biologists, that link was established (Hasle and Fryxell, 1977), but no fossil members were examined from that point of view. Now, our SEM observations described below in detail show clearly that three fossil plicated species belong to Thalassiosira. Although we have not yet examined other plicated species in detail, morphologic similarities recognized under the LM lead us to make the following new combinations.

\section{TAXONOMY OF NEW THALASSIOSIRA COMBINATIONS}

Thalassiosira flexosa (Brun) Akiba and Yanagisawa n. comb.

Basionym. Coscinodiscus flexosus Brun, 1894, pl. 15, figs. 38-39. Remarks. See comments under Thalassiosira yabei.

Thalassiosira mioplicata Akiba and Yanagisawa nom. et comb. n.

Basionym. Coscinodiscus miocenicus Schrader, 1973a, p. 703, pl. 7, figs. 11-12.
Remarks. New specific name is introduced here because of the presence of Thalassiosira miocenica Schrader (1974a, p. 916, pl. 22, figs. 1-5).

Thalassiosira moholensis (Schrader) Akiba and Yanagisawa n. comb.

Basionym. Coscinodiscus moholensis Schrader, 1974b, p. 535, figs. 3:3-5.

Thalassiosira plicatoides (Simonsen) Akiba and Yanagisawa n. comb.

Basionym. Coscinodiscus plicatoides Simonsen, 1974, p. 17, pl. 15, figs. 1-3.

Thalassiosira praeyabei (Schrader) Akiba and Yanagisawa n. comb.

Basionym. Coscinodiscus praeyabei Schrader, 1973a, p. 703, pl. 6, fig. 16; pl. 7, figs. 17-20, 22-23.

Thalassiosira brunii Akiba and Yanagisawa comb. et nom. n.

(Plate 31, Fig. 8; Plate 32, Figs. 1-10; Plate 33, Figs. 1-6)

Basionym. Coscinodiscus temperei var. delicata Barron, 1981, p. 528 , pl. 3, figs. 1, 3-4.

Synonym. Coscinodiscus temperei Brun, Schrader, 1974b, fig. 2: 29-33.

Type locality. Sample 158-27-6, 30-32 cm of DSDP Leg 16, eastern equatorial Pacific.

Stratigraphic occurrence. Rare in an interval from the upper middle Miocene Denticulopsis praedimorpha Zone (NPD5B) through the upper Miocene Denticulopsis katayamae Zone (NPD6A).

Observations (based on specimens referable to $T$. cf. brunii). The valve is elliptical in outline with a longitudinal plication. The valve mantle is shallow and slanting, ending at a narrow brim (Plate 33, Fig. 4). The long axis of valve is $25-50 \mu \mathrm{m}$ in length and the short axis $22-31 \mu \mathrm{m}$. The areolae of valve face are polygonal in outline with external circular foramina (Plate 32, Figs. 1-6) and internal polygonal cribra (Plate 33, Figs. 1-6). The areolae are arranged in radial rows, 9-11 areolae in $10 \mu \mathrm{m}$. The mantle has a row of areolae, 11-14 in $10 \mu \mathrm{m}$, with oval external foramina slightly larger than those of valve face but smaller under the marginal strutted processes (Plate 32, Fig. 4). A narrow hyaline area is present between the valve face and the mantle on the concave side but absent on the convex side (Plate 32, Figs. 1, 3, 5-6). A single labiate process is located between two marginal strutted processes in the middle of the arc of concave side (Plate 32, Figs. 2, 3, 5-9; Plate 33, Figs. 1-2, 6). This process has an external tube with a wide outer opening and an internal slit oriented tangentially (Plate 33, Fig. 6). A ring of marginal strutted processes, with four internal struts and satellite pores is situated between valve face and mantle (Plate 33, Fig. 4). The processes are distributed more densely in the concave side than in the convex side; $4-5$ processes in $10 \mu \mathrm{m}$ in the concave side and 3-4 in $10 \mu \mathrm{m}$ in the convex side. In the concave side, they have external tubes that decrease gradually in height towards the convex side and are absent in the convex half of the valve (Plate 32, Figs. 2-3, 5-6). Several (3-8) other strutted processes are scattered sparsely among the areolae of convex side (Plate 33, Figs. 1-3). These processes have short internal extensions with four struts and satellite pores (Plate 33, Fig. 5) and external small circular openings without tubes (Plate 32, Fig. 5). The larger specimens have more processes than the smaller ones.

Remarks. This species resembles Thalassiosira temperei (Brun) $\mathrm{n}$. comb., but is characterized mainly by much finer areolation than the latter species (10-13 versus 5-7 in $10 \mu \mathrm{m}$; Barron, in press a).

Although Barron (1981) described this species as a variety of $T$. temperei, the different size of areolation and the disparate stratigraphic and geographic ranges of the two taxa warrant designation of this form as a distinct species. $T$. brunii is a low-to-middle latitude species and ranges from upper middle Miocene through lower upper Miocene, whereas $T$. temperei is a middle-to-high latitude one and occurs from the upper Miocene through lower Pliocene (Barron, 1981; in press a).

Another taxon described as Coscinodiscus temperei var. aspinosa Schrader $(1973$ a, p. 704 , pl. 6, figs. 10,14,17) is seemingly conspecific with $T$. brunii. The specimens examined by SEM are identical to $C$. temperei Brun sensu Schrader (1973a, pl. 6, figs. 18-19; pl. 7, figs. $1-5,8-9$ ), and are also similar to $T$. brunii in the size of areolation, although they have very clear hyaline areas. We refer to them also as $T$. cf. brunii. 
Possible specific epithet for this species, "delicata," is preoccupied by Thalassiosira delicata Akiba (this volume), therefore the present epithet is given here.

Thalassiosira grunowii Akiba and Yanagisawa comb. et nom. n. (Plate 27, Fig. 5; Plate 29, Figs. 1-8b; Plate 30, Figs. 1-10)

Basionym. Coscinodiscus plicatus Grunow in Schmidt et al., 1878, pl. 59 , fig. 1 .

Type locality. Nankoori, Nicobar Island.

Stratigraphic occurrence. This species occurs very sporadically in an interval from middle Miocene Crucidenticula nicobarica Zone (NPD5A) through lower upper Miocene Thalassiosira yabei Zone (NPD5C).

Observations. The frustule is rectangular in girdle view. The outer surface of valvocopula is perforated by small pores, 44 in $10 \mu \mathrm{m}$ (Plate 29 , Figs. 4-7). The copula is finely perforated adjacent to valvocopula by vertical rows, composed of 2-3 very small pores, except at the lingula where there are more (Plate 29, Fig. 5). The three hyaline pleurae are narrower than the valvocopula and copula (Plate 29, Figs. 4, 6-7). The openings of bands of cingulum are offset to the right (dextral) (Plate 29, Figs. 4, 6). The valve is circular in outline with a plication, one side convex and the other concave. The valve mantle is shallow and slanting, ending at the narrow brim. The diameter is $35-45$ $\mu \mathrm{m}$. The areolae of valve face are polygonal in outline with external circular foramina (Plate 29, Fig. 8; Plate 30, Fig. 8) and internal polygonal cribra (Plate 30, Figs. 1-4, 10). They are arranged in radial rows, 7-9 areolae in $10 \mu \mathrm{m}$, with secondary spiral rows, except at the upper part of mantle where areolae are smaller. The lower mantle to the brim is ribbed, $11-13$ in $10 \mu \mathrm{m}$, and the spaces between the ribs seem to be oval foramina with internal cribra, which are small under the marginal strutted processes (Plate 29, Figs. 4-6, Plate 30, Fig. 9). A single labiate process is located between two marginal strutted processes in the middle of the arc of concave side, slightly inside the ring of strutted processes (Plate 29, Figs. 1-2; Plate 30, Figs. 1, 3-7). It has an external tube and a lip-shaped internal slit oblique to the tangential direction (Plate 30, Figs. 3-4). There is a ring of marginal strutted processes in the mantle, 4 in $10 \mu \mathrm{m}$ or one process for every fourth to fifth mantle foramen (Plate 29, Figs. 1-2, 4, 6; Plate 30, Figs. 1, 6, 8). Each strutted process has four struts and satellite pores internally and an external tube possessing a short spine (Plate 30, Figs. 4, 8-9). Other strutted processes without external tubes are sparsely scattered either on the valve face of the convex side (Plate 29, Fig. 3) or over the valve face (Plate 30, Figs. 2, 10). They have four or sometimes five struts and satellite pores internally (Plates 30, Fig. 10).

Remarks. Possible specific epithet of "plicata" for this species is preoccupied by $T$. plicata Schrader (1974a, p. 917, pl. 3, figs. 1-2, 4-9); therefore, the new epithet is given here.

This species is similar to T. yabei (Kanaya) n. comb., but is distinguished from it by finer areolae, 7-9 in $10 \mu \mathrm{m}$ for $T$. grunowii compared to 4-7 in $10 \mu \mathrm{m}$ for $T$. yabei, and numerous and regularly spaced marginal spines.

Two distinct valve morphotypes are recognized; one type with strutted processes scattered only on its convex side (Plate 29, Figs. 3, 8), and the other with those processes scattered over the entire valve face (Plate 30, Figs. 2, 10). Although the two types differ slightly from each other in the density of areolae (the former has 7-8 areolae in $10 \mu \mathrm{m}$ and the latter $8-9$ in $10 \mu \mathrm{m}$ ), all the other features are almost the same. Further investigations will be needed to ascertain whether the difference is one of specific level, of infraspecific variations, or merely a result of the heterovalvate nature of this species.

Thalassiosira temperei (Brun) Akiba and Yanagisawa, n. comb. (Plate 31, Figs. 1-7)

Basionym. Coscinodiscus temperei Brun in Brun and Tempère, 1889 , p. 33 , pl. 8 , fig. 2 .

Synonym. Coscinodiscus temperei Brun, Kanaya, 1959, p. 84, pl. 4, fig. 8; Koizumi, 1968, pl. 32, fig. 28; Barron, 1980a, p. 672, pl. 4, fig. 5 ; Barron, 1981 , p. 528 , pl. 3 , figs. 7-8.

Type locality. Calcaire de Sendai, Japon; uppermost upper Miocene (Rouxia californica Zone).

Stratigraphic occurrence. This species ranges from upper Miocene Denticulopsis katayamae Zone (NPD6A) through the lower part of the uppermost upper Miocene to the lower Pliocene Neodenticula kam- tschatica Zone (NPD7B), but occurrences are generally rare and only fairly common in the uppermost upper Miocene Rouxia californica Zone (NPD7A).

Remarks. This species is similar to $T$. brunii Akiba and Yanagisawa, but T. temperei is distinguished by its larger areolae and also by its generally larger valves and very conspicuous central spine (labiate process), which is clearly discernible by LM (Plate 31 , Figs. $3-5,7$ ). No SEM photographs are presented for this species here, but our preliminary SEM observations reveal submicroscopic similarities between this species and $T$. cf. brunii previously described.

\section{Thalassiosira yabei (Kanaya) Akiba and Yanagisawa n. comb.} (Plate 27, Figs. 1-2; Plate 28, Figs. 1-9)

Basionym. Coscinodiscus yabei Kanaya, 1959, p. 86, pl. 5, figs. 6-9. Type locality. Loc. no. Ao-12, Owasawa Formation, Hirosaki Area, Aomori Prefecture, northeastern Honshu, Japan; upper middle Miocene (Denticulopsis praedimorpha Zone).

Stratigraphic occurrence. Middle Miocene Crucidenticula nicobarica Zone (NPD5A) through the middle part of the upper Miocene Thalassionema schraderi Zone (NPD6B) (Barron, 1980a). Its occurrence within this interval is generally rare to sporadic except for lower upper Miocene T. yabei Zone (NPDSC), where it occurs consistently and frequently and characterizes the zone.

Observations. The areolae of the valve face are polygonal in outline with external circular foramina and internal polygonal cribra (Plate 28, Figs. 5-9). The shallow mantle has a row of alternating larger and smaller areolae with oval external foramina. A single labiate process (Plate 28, Figs. 4, 7, 9) is located in the middle of the arc of concave side, occupying the position where one of marginal strutted processes might be located (Plate 28, Fig. 4). This process has a large lip-shaped extension oblique to the tangential direction (Plate 28, Fig. 7). Its outer opening is a simple pore slightly smaller than areolae (Plate 28, Fig. 2). A ring of marginal strutted processes is situated between the valve face and mantle, about 5 processes in $10 \mu \mathrm{m}$ (one process for every second mantle areolae) (Plate 28, Figs. 2, 4, 7). Other strutted processes $(7-13)$ are scattered sparsely among the areolae of convex side (Plate 28, Figs. 4, 6, 8). Each strutted process of the species has a short interval extension with four struts and satellite pores, and a small circular outer opening without a tube (Plate 28, Fig. 6). Several long spines (7-8 $\mu \mathrm{m}$ in length), irregularly spaced, are present just inside the marginal ring of strutted processes (Plate 28, Figs. 1-3).

Remarks. This species is similar to T. grunowii Akiba and Yanagisawa comb et nom. n., but is distinguished from the latter by much coarser areolae, smaller valve, and inconspicuous marginal spines.

T. yabei also resembles T. flexosa (Brun) Akiba and Yanagisawa n. comb., which was originally described from the "Abashiri deposit" of Hokkaido (Abokiri; Ile Jess, Japon) (Brun, 1894). The "Abashiri deposit" is probably from the Masuura Formation, which outcrops in the vicinity of Abashiri-shi, eastern Hokkaido and belongs to Denticulopsis praedimorpha Zone (Akiba, unpublished data). T. yabei also occurs in the same horizon, although type localities of the two species are geographically separated. After a short examination of the type slide of Coscinodiscus flexosus Brun, Kanaya (1971, p. 555) expressed his conviction that $C$. yabei is a synonym of $C$. flexosus Brun, but he did not formerly make the two species synonyms. His judgment seems reasonable to us, but until thorough comparative studies of the two species are made, we follow the opinion of Schrader (1973a, p. 702) who described $C$. flexosus in detail and remarked that it can be distinguished from $C$. yabei by the circular areolae, smaller margin, and the different structure of margin. Recently, Kanaya commented to us (pers. comm., 1983) that several distinct plicate species of Coscinodiscus are mounted in the type slide of $C$. flexosus Brun in J. Brun's collection at the Botanical conservatory in Geneva, and that he could not precisely specify the type specimen during his brief examination of the slide.

Submicroscopic observations described above clearly show that this species is a member of Thalassiosira. The conspicuous long spines have not been recognized previously, possibly because of their irregular spacing and internal position on valve face, coupled with pronounced silicification of the valve. The spines are imperceptible under LM (Plate 27, Figs. 1-2), even though the same samples used for SEM observations were examined.

The "marginal petal-shaped structure" in the original description (Kanaya, 1959) is perhaps merely an artifact produced by alternating large and small areolae at mantle. 


\section{OTHER ZONAL MARKER SPECIES}

\section{Actinocyclus ingens Rattray}

(Plate 34, Figs. 1-9, Plate 35, Figs. 1-9)

Rattray, 1890, p. 149, pl. 11, fig. 7; Kanaya, 1959, p. 97, pl. 7. figs. $6 a-9$; pl. 8, figs. 1-4b; 1971, pl. 40.6, figs. 1-8; Schrader, 1973a, pl. 18, figs. 1-4, 7; Baldauf and Barron, 1980 , p. 103, text-fig. 1 , pl. 1 , figs. $1-4$.

Synonym. Coscinodiscus elegans Greville, 1866 , p. 3, pl. 1, fig. 6 ; Kanaya, 1959, p. 75, pl. 3, figs. 6-7; Simonsen, 1975, p. 92; Actinocyclus tsugaruensis Kanaya, 1959, p. 99, pl. 8, figs. 5-8; Coscinodiscus novozealandicus Hanna, 1932, p. 182, pl. 9, fig. 3.

Stratigraphic occurrence. This species occurs commonly to abundantly in an interval from lower Miocene Crucidenticula kanayae Zone (NPD3A) through uppermost upper Miocene Rouxia californica Zone (NPD7A), and in some cases it occurs extremely abundantly, especially in poorly preserved assemblages of the lower to middle Miocene. Its first occurrence defines the base of the $C$. kanayae Zone (NPD3A), and its last is near the top of upper Miocene. Upward reworking of this heavily silicified species makes it difficult to recognize its last occurrence precisely.

Descriptions and observations. In girdle view the frustule is rectangular with rounded corners. Pervalvar axis is shorter than the diameter (Plate 35, Fig. 8). Cingulum, 6-7 $\mu \mathrm{m}$ wide, is composed of two open bands; the broader one, $4.5-5.5 \mu \mathrm{m}$ wide, and the narrower one, $1.5 \mu \mathrm{m}$ wide. Both are hyaline and thick (Plate 35, Fig. 8). The valve is circular in outline with the valve face flat or concentrically wavy. This concentric undulation is more pronounced in larger valves, whereas smaller valves tend to be flat (Plate 34, Figs. 1-9; Kanaya, 1959). There are two types of wavy valves: one depressed at the center, raised in the subcentral zone, depressed in the submarginal zone, and raised in the marginal zone (Plate 35, Figs. 1, 5); the other raised in the center, depressed in the submarginal zone, and raised in the marginal zone $(=$ Actinocyclus ingens var. nodus Baldauf; Plate 34, figs. 8-9; Plate 35, Figs. 2, 4). The mantle is moderately deep and slanting with slightly convex surface, ending at the narrow vertical edge (Plate 35, Figs. 1-2, 4-6, 8-9). The areolae of the valve face have external rounded cribra (Plate 35, Figs. 5-6) and internal circular foramina with the brimmed edges (Plate 35, Fig. 7). They are arranged in radially lineate rows. The primary rows extend the length of radius, whereas the secondary rows do not reach the center. The mantle areolae are fine with rhombic to subrounded external cribra, arranged in radial rows, 14-20 areolae in $10 \mu \mathrm{m}$, with distinct secondary spiral rows (Plate 35, Figs. 1-2, 4-6). The valve center and the raised parts of valve face are sometimes hyaline (Plate 35, Figs. 2, 4). A ring of labiate processes, 8-9 in $10 \mu \mathrm{m}$, is located on the upper part of the mantle, with each process at an extension of each primary row of areolae of the valve face (Plate 35, Fig. 7). The labiate process has an internal tube with a lip-shaped opening oriented in the tangential direction. The external opening is a circular pore, which is sometimes difficult to distinguish from the mantle areolae. A pseudonodulus is located at the raised marginal zone between the valve face and mantle (Plate 35, Fig. 3). It is of areolate-operculate type (Simonsen, 1975), with internal fine areolae and external opeculum. The pseudonodule is also difficult to recognize in general, especially in the smaller and flat valves. Small and short spines are sometimes present on the raised marginal zone (Plate 35, Figs. 1, 4), and these are variable in number and spacing.

Remarks. This species is characterized by a circular valve with isolated rounded areolae, which are radially arranged and of almost equal size. It is one of the most common Miocene diatoms in the North Pacific as well as in the world (details in Baldauf and Barron, 1980). This form has also been reported from the Antarctic region (Donahue, 1970; McCollum, 1975; Schrader, 1976), although Russian workers (e.g., Jousé, 1977; Mukhina, 1979) have assigned the Antarctic form to Coscinodiscus margaritaceous Castracane (1886, p. 164, pl. 18, fig. 3 ).

The long geologic range and wide morphologic variations of this species (Kanaya, 1971) have led to several specific names for it. Small and flat forms in which the pseudonodulus is not generally noticeable have been called Coscinodiscus elegans Greville. Simonsen (1975) clarified that $C$. elegans is conspecific with $A$. ingens by examining the type specimens of the former. A. tsugaruensis Kanaya is merely a larger form of $A$. ingens with a flat valve and very dense areolation. Typically, larger forms are either flat or more concentrically undulated, but a wide range of intermediate forms exist (Koizumi, 1973b; Kana- ya, 1971). Baldauf and Barron (1980) distinguished one of those concentrically undulating forms as a distinct taxon, $A$. ingens var. nodus Baldauf (Bauldauf and Barron, 1980, p. 104, text-fig. 1, pl. 1, figs. 5-9; Plate 34, Figs. 8-9, Plate 35, Figs. 2, 4), and this variety is stratigraphically useful.

\section{Actinocyclus oculatus Jousé \\ (Plate 46, Figs. 13, 15-16)}

Donahue, 1970, p. 135, pl. 2, figs. 6-7; Koizumi, 1973b, pl. 2, figs. 8-9; Schrader, 1973a, pl. 18, figs. 5-6, 9-14, 16, 18; pl. 19, fig. 5 .

Original description. Jousé, 1968, p. 18, pl. 2, figs. 6-7 (in Latin and Russian, translated by Fumio Akiba): "Valve more or less with central area, $30-52 \mu$ in diameter. Areolae radially arranged forming fascicules that decrease in size from the center towards the margin, 4-5.5 at center and 10 in $10 \mu$ at margin. Margin 4-5 $\mu$ wide, with spines. Ocellus rarely visible."

Type locality. Pacific Ocean basin sediment.

Stratigraphic occurrence. Common in lower Quaternary A. oculatus Zone (NPD10). Its last occurrence defines the top of the zone.

Remarks. No SEM observations of this species were made. This species is similar to $A$. ochotensis Jousé (1968, p. 17, pl. 2, figs. 2-5), but is distinguished from it by large areolae at the center and conspicuously decreasing areolae size towards the margin. Recently, C. Sancetta (pers. comm., 1983) remarked that she observed some morphologically continuous variations from this species to Actinocyclus curvatulus Janisch and questioned the taxonomic status of $A$. oculatus as a distinct species. Morphologies of the two species are, nevertheless, distinct from each other in general, and their different stratigraphic occurrences warrant distinguishing them.

\section{Genus KISSELEVIELLA Sheshukova-Poretzkaya (1962)}

Remarks. The genus has long been regarded as monospecific since its erection, but Akiba (1980) suggested that its type species, $K$. cari$n a$, is heterogenous, and Akiba (this volume) describes a second species of the genus, $K$. ezoensis. We describe here another species, $K$. magnaareolata. It is possibly not a Neogene species, but we tentatively include it here for the purpose of demonstrating that Kisseleviella will be represented by more species in the course of future investigations. The systematic position of this genus is not yet certain (Simonsen, 1979), although close relationships of the genus with other genera such as Cymatosira, Rutilariopsis, and Campylosira have been suggested (Fenner, 1979). Possibly, it is an extinct member of family Cymatosiraceae, established by Hasle and others (1983).

\section{Kisseleviella carina Sheshukova-Poretzkaya}

(Plate 36, Figs. 1-13; Plate 37, Figs. 1-9)

Sheshukova-Poretzkaya, 1962, p. 207, text-figs. 1a-b, pl. 1, figs. 2a-d; 1967 , p. 236 , pl. 40 , figs. $6 a-c$, pl. 41 , figs. $5 a-c ; 1962$, p. 207 , text-figs. 1a-b, pl. 1, figs. 2a-d; Koizumi, 1973b, p. 833, pl. 7, figs. 3-4.

Type locality. Sample N 1262 from Neogene of Schmidt Peninsula, North Sahaline.

Stratigraphic occurrence. Common to abundant from lower Miocene Thalassiosira fraga Zone (NPD2) through lower middle Miocene Denticula lauta Zone (NPD4A) in general, although much younger occurrences are reported (Koizumi, 1977). In some cases, monospecific assemblages of this species are found, but in others its occurrence is sporadic and fluctuating within short intervals (Akiba et al., 1982).

Description and observation. This extinct species forms a long colonial chain, which is curved gently (Plate 36, Fig. 13; Plate 37, Fig. 1) and often includes resting spores. The frustule of the vegetative cell is rectangular with a central and two subpolar bulges on each valve (Plate 36, Fig. 12). The central bulge of one valve is much higher than that of the other valve. The cingulum is composed of several elements with fine striations (Plate 37, Figs. 3-4, 8-9). However, it must be pointed out that apical ends of the element or valve itself protrude and unite with those of next frustule in the chain (Plate 37, Figs. 3, 8). This feature is barely perceptible in LM. Valve is lanceolate to linearlanceolate in outline with gently protruding apices with fine areolae over almost entire valve face except for around the central and subpolar bulges. The areolae are occluded by finely constructed rotae (Plate 37, Fig. 5). Valves of a frustule are always heterovalvate. One valve has a strongly swollen bulge in the center and small bulges at both apices, 
all of which bear several spiny tubercles at their tops (Plate 36, Fig. 1). A single labiate process is located near the central bulge, slightly oblique to the margin (Plate 37, Figs. 6-7). The other valve has less swollen bulges, bearing annular tubercles (Plate 36, Fig. 2). This type has no labiate process. The spiny and annular tubercles interlock to unite cells in colonies (Plate 36, Figs. 10, 12; Plate 37, Figs. 1-4, 6, 8-9).

Resting spores are basically composed of two types of frustules. One is endogenous and isovalvate (Plate 36, Fig. 10), and the other is semi-exogenous and heterovalvate (Plate 36, Figs. 8-9). Possibly no cingulum is present in the resting spores. The valve of the isovalvate variety has only a central bulge with spiny tubercles and is hyaline (Plate 36, Fig. 4). In some cases, this type of valve bears a broad areolated plate at the central bulge (Plate 36, Figs. 6-7; Plate 37, Fig. 2). The nature of this plate is not certain at present, but it possibly is a rudimentary valve formed during resting spore formation. Valves of heterovalvate resting spores have both central and subpolar bulges with either spiny tubercles (Plate 36, Fig. 3) or annular tubercles (Plate 36, Fig. 5). The latter type of valve looks hyaline by LM, but an SEM micrograph (Plate 37, Fig. 2) shows that it has very tiny tubercles covering the valve face. Two cells of the heterovalvate resting spore are united by interlocking spiny and annular tubercles (Plate 36, Fig. 9). Valve, frustule combinations, and a suggested process of resting spore formation are shown in Figure 3.

Remarks. The polymorphic character of this species was noted by Sheshukova-Poretzkaya $(1962,1967)$, but she did not discuss the possible biological implications, an aspect later described by Akiba (1980). Vegetative cells and colonies of this species are extremely rare in normal diatomaceous sediments. Some calcareous nodules contain excep- tionally well-preserved diatom flora including numerous long colonies, and our present observations were possible only by utilizing such "time capsule" material.

In spite of its highly polymorphic nature, its valve outline seems to be uniform (Akiba, 1980). In this connection, $K$. carina illustrated by Hajós $(1976$, pl. 25, figs. 5 -9, 14) from lower Oligocene sediments of DSDP Leg 29, Site 280A in the Tasman Sea, the South Pacific, must be reexamined, because it has acute apices. Dolmatova (pers. comm., 1979) found another, possibly distinct species of this genus from Oligocene to lower Miocene sediments from Kamchatka.

\section{Kisseleviella ezoensis Akiba}

(Plate 38, Figs. 1-9)

Original description. Akiba, this volume.

Type locality. Sample JDS-8482, Kiroro Formation, Honbetsu Area, eastern Hokkaido; lower Miocene (Thalassiosira fraga Zone).

Stratigraphic occurrences. Common in and restricted to the lower Miocene Thalassiosira fraga Zone (NPD2), and hence is a good marker species of the horizon.

Remarks. This species resembles $K$. carina Sheshukova-Poretzkaya, but is distinguished from the latter by steeply attenuated apices and a transapically elongated central bulge with tubercles.

\section{Kisseleviella magnaareolata Akiba and Yanagisawa n. sp.} (Plate 38, Figs. 10-18)

Description. Frustule is heterovalvate; one valve has annular tubercles and the other spiny tubercles. Valve is very slightly convex, quad-
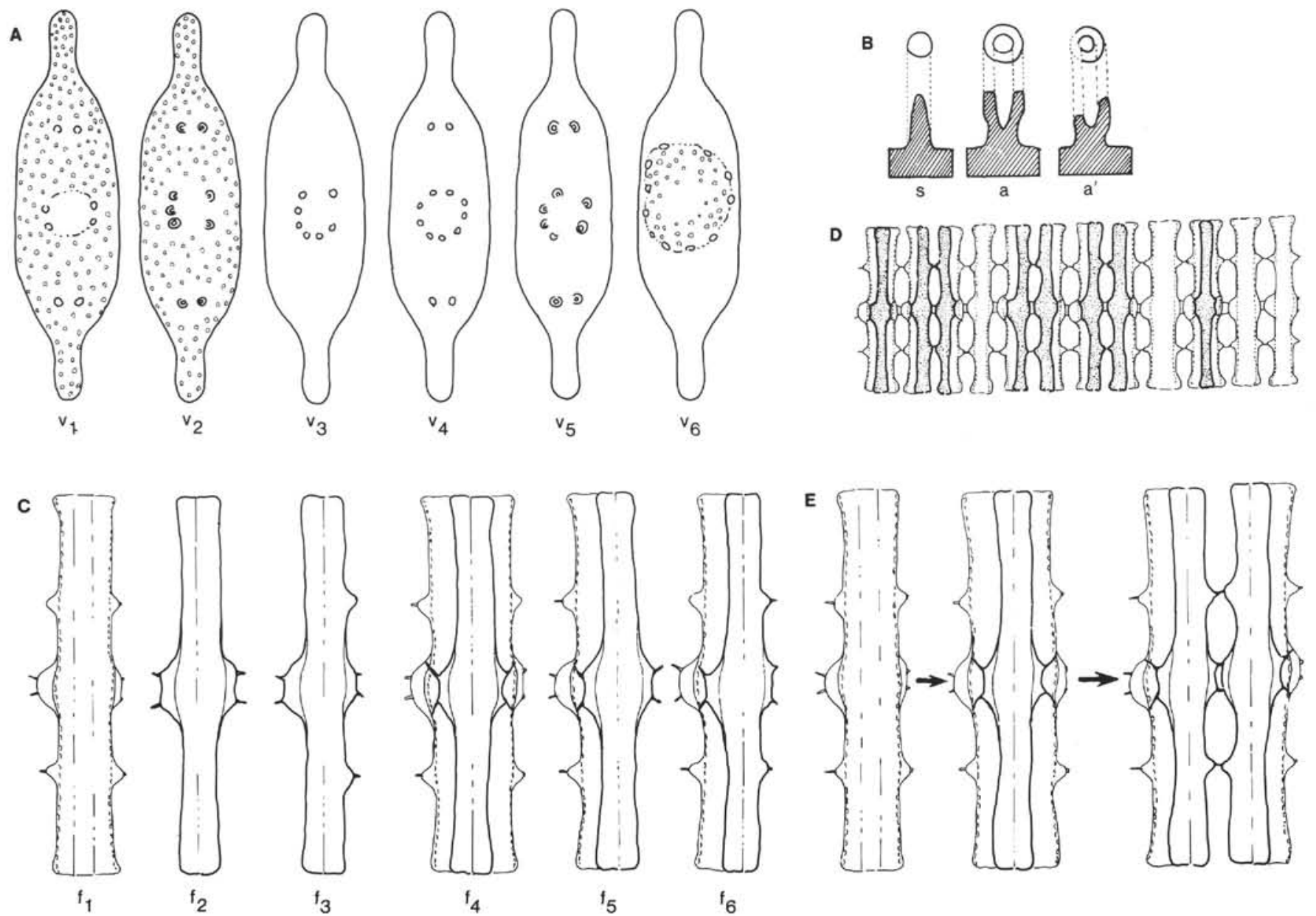

Figure 3. Schematic drawings of various morphotypes of Kisseleviella carina. A. Valve, $v_{1}-v_{2}:$ vegetative valve, $v_{3}-v_{6}: v$ valve of resting spore. B. Tubercle, s: spiny tubercle, a: annular tubercle, $a^{\prime}$ : semi-annular tubercle. C. Frustule, $f_{1}$ : vegetative cell, $f_{2}-f_{3}$ : resting spore, $f_{4}-f_{6}$ : combination of vegetative cell and resting spores. D. Colony. E. Suggested process of resting spore formation. 
rangular slightly inflated in the middle with attenuated apices, usually 9-17 $\mu \mathrm{m}$ long and about $10 \mu \mathrm{m}$ wide. In rare cases, the valve is very large, about $38 \mu \mathrm{m}$ long and $18 \mu \mathrm{m}$ wide, almost lanceolate in outline. Valve face is very coarsely areolated, $7-8$ areolae in $10 \mu \mathrm{m}$, with a hyaline central area. Several annular or spiny tubercles are arranged around the central hyaline area in a crown, and an additional subpolar one is present between central area and each apex, somewhat eccentrically. Frustule, $9-10 \mu \mathrm{m}$ in depth, is made from valve and cingulum with a row of small puncta. Colonial chain is formed possibly by means of interlockings of spiny tubercles with annular ones. Frustules in colonial chain are closely set, about $2 \mu \mathrm{m}$ apart. No resting spores have been observed.

Holotype. Plate 38, Fig. 10, Sample JDS-10649, Takatsuru Formation, Oligocene(?), Bōsō Peninsula, central Japan, slide No. Zu 3/17 deposited in the Hustedt Collection, Bremerhaven.

Paratype. Plate 38, Fig. 15 from the same sample as above, a colony of two and one-half cells, slide No. $\mathrm{Zu} \mathrm{3/18}$ deposited in the Hustedt Collection, Bremerhaven.

Stratigraphic occurrence. Only found in the type material at present.

Remarks. This species is easily differentiated from $K$. carina by valve outline and by coarser areolae. It is similar to $K$. ezoensis in valve shape, but it is differentiated by coarser areolation and circular central area. In the genus Kisseleviella, the new species has extremely coarse areolation, causing it to resemble several species of other genera, for instance, Cymatosira lorentziana Grunow (Fryxell and Miller, 1978, p. 122, figs. 20-31) and Praecymatosira monomembranacea Strelnikova (In Jousé et al., 1979, p. 64, figs. 169-176). K. magnaareolata, however, is distinguished from those species by its central crown of tubercles and subpolar tubercles, features missing in those other genera.

\section{Nitzschia jouseae Burckle \\ (Plate 39, Figs. 1-6)}

Original description. Burckle, 1972, p. 240, pl. 2, figs. 17-21.

Type locality. Sample RC 12-65, $447 \mathrm{~cm}$, eastern equatorial Pacific. Stratigraphic occurrence. This low-latitude species rarely occurs in this region, in the upper part of lower Pliocene Neodenticula kamtschatica Zone (NPD7B) in Hole 438A (Barron, 1980a) and Hole 584 (Akiba, this volume), both sites located off northeastern Honshu. Until now, no occurrence of this species has been reported from on-land sequences of Japan.

Remarks. No SEM observations made at present. This species resembles Nitzschia miocenica Burckle and N. pliocena (Brun) Mertz, but differs from them by coarser transapical costae.

\section{Nitzschia miocenica Burckle}

(Plate 39, Figs. 7-15; Plate 41, Figs. 1-2)

Original description. Burckle, 1972, p. 240, pl. 2, figs. 10-15.

Type locality. Sample RC $12-65,1065 \mathrm{~cm}$, eastern equatorial Pacific.

Stratigraphic occurrence. This low-latitude species occurs only rarely to sporadically in uppermost upper Miocene Rouxia californica Zone (NPD7A) to lowest part of Neodenticula kamtschatica Zone (NPD7B) (Barron, 1980a; Akiba, this volume). We have found rare occurrences in the $R$. californica Zone of Hokkaido.

Observations. There are double rows of transapical puncta between two internal costae on the outside of valve (Plate 41, Fig. 1). On the center of valve inside, a row of large foramina runs in apical direction, decreasing in size toward both ends (Plate 41, Fig. 2). Between each two internal costae, a chamberlike hollow space communicates with the valve interior through this large foramen (Plate 41, Fig. 2). The raphe slit is apparently divided at its center (Plate 41, Fig. 1).

Remarks. This species resembles Nitzschia jouseae Burckle in its short and broad valve (compare Plate 39, Figs. 1-3 and Figs. 9, 13-15), but is distinguished by narrower costae and "invagination" restricted to center.

Barron (1980a) states that younger form of this species seems to have finer structure. On the other hand, this species as found in Hokkaido seems to have slightly coarser structure (Plate 39, Figs. 12-15) than that in the type locality, the equatorial Pacific (Plate 39, Figs. $7-11$ ), namely, numbers of costae per $10 \mu \mathrm{m}$ are $9-10$ and $10-12$, respectively.

Our SEM observations reveal that the real structure of "invagination" of this species derives from deeply developed transapical costae and their occlusion by a siliceous layer at the basal parts. This combination leaves a row of central foramina and is similar to aspects of Crucidenticula, Denticulopsis and Neodenticula, and also Nitzschia reinholdii and $N$. marina.

\section{Nitzschia pliocena (Brun) Mertz}

(Plate 40, Figs. 1-7)

Mertz, 1966, p. 30; Koizumi, 1975, pl. 4, figs. 18-32 as Nitzschia pliocena (Brun) Kanaya; Harper in Ujiie et al., 1977, pl. 3, figs. 16-17 as Nitzschia pliocena sensu Koizumi; Barron, 1980a, pl. 2, figs. 1-2 as Nitzschia pliocena (Brun) Kanaya and Koizumi.

Synonym. Fragilaria pliocena Brun, 1891 , p. 28 , pl. 14 , fig. 7 , pl. 17, fig. 7; Fragilariopsis pliocena (Brun) Sheshukova-Poretzkaya, 1967 , pl. 47 , fig. 13 , pl. 48 , fig. 7 ; not Koizumi, 1968, p. 214, pl. 34, figs. 13a-16; not Kanaya, 1971, p. 556, pl. 40.3, figs. 7a-8b: not Nitzschia pliocena (Brun) Mertz, 1966, pl. 6, figs. 14-20; not Nitzschia pliocena (Brun) Wornardt, 1967, p. 88, figs. 212-213.

Stratigraphic occurrence. Frequent to common from the middle part of upper Miocene Thalassionema schraderi Zone (NPD6B) through the middle part of Rouxia californica Zone (NPD7A), and restricted to that interval (Fig. 1).

Remarks. This species resembles $N$. reinholdii Kanaya ex Schrader, but is distinguished from it by more rounded apices, robuster and narrower transapical costae (11-13 versus 9-10 costae in $10 \mu \mathrm{m}$, after Kanaya and Koizumi, 1970). No SEM observations of this species are available at present.

This middle-to-high latitude species occurs most commonly among other Nitzschia species treated in this chapter and is restricted to a very limited interval as above. Its stratigraphic utility, however, was recognized only by Barron (1980a), presumably because it is frequently mixed with $N$. reinholdii and also because the particular late Miocene horizon containing this species has not been well studied previously.

\section{Nitzschia reinholdii Kanaya ex Schrader}

(Plate 40, Figs. 8-9, Plate 41, Figs. 3-4)

Schrader, 1973a, p. 708, pl. 4, figs. 12-16, pl. 5, figs. 1-9; Kanaya and Koizumi, 1970, p. 58, nom. invalid.; Simonsen, 1974, p. 54; Barron, $1980 \mathrm{a}$, pl. 2, fig. 11, pl. 3, fig. 1 as Nitzschia reinholdii Kanaya and Koizumi.

Synonym. Fragilaria pliocena Brun, Reinhold, 1937, p. 104, pl. 12, fig. 18; Nitzschia pliocena (Brun) Wornardt, 1967, p. 88, figs. 212-213 Fragilariopsis pliocena (Brun) Sheshukova-Poretzkaya, Koizumi, 1968, pl. 34, figs. 13-15, not Sheshukova-Poretzkaya, 1967, p. 305, pl. 47, fig. 13 , pl. 48 , fig. 7 .

Type locality. Not designated before present.

Stratigraphic occurrence. This species occurs rarely but fairly consistently in an interval from uppermost upper Miocene Rouxia californica Zone (NPD7A) through the middle part of the Quaternary Rhizosolenia curvirostris Zone (NPD11) (Barron, 1980a).

Observations. There are decussate double rows of puncta between each two internal costae on the outside of valve (Plate 41, Fig. 3). On the inside of valve, two rows of submarinal pores parallel both margins (Plate 41, Fig. 4) and may lead to inner hollow spaces just like those of $N$. marina. The raphe slit seems to be continuous (Plate 41, Fig. 3).

The fine structure of $N$. marina is identical to that of $N$. reinholdii (Plate 41, Figs. 5-6), but a broken specimen of the former reveals an interesting internal structure, which may also occur in $N$. reinholdii. Each pore of the raphe-bearing margin leads to a small chamberlike hollow space surrounded by both the internal costae and mantle wall, and (as noticed by Simonsen, 1974) each pore of the other margin leads to a large hollow space expanding beneath the valve face (Plate 41, Fig. 6).

Remarks. This species resembles Nitzschia pliocena (Brun) Mertz as the above list of synonyms shows, but is distinguished from it by a generally larger valve, more acute apices, slightly narrower costae, and the presence of a submarginal row of inner openings. It also resembles N. marina Grunow (Simonsen, 1974, p. 53, pl. 40, fig. 4), but is easily differentiated from the latter by its shorter valve.

Kanaya and Koizumi (1970) were the first to distinguish this species from the above two related species, but their description is invalid (Simonsen, 1974). 
Rhizosolenia barboi (Brun) Tempère and Peragallo

(Plate 42, Figs. 3-5, 7, 10-11; Plate 44, Figs. 1-8)

Original description. Brun, 1894 , p. 87 , pl. 5, figs. $16-17,23$ as Pyxilla (Rhizosolenia?) barboi Brun.

Synonym. Rhizosolenia curvirostris var. inermis Jousé, 1971, pl. 15, fig. 2 .

Type locality. Calcaire de Sendai, Japan, upper Miocene (Rouxia californica Zone, NPD7A).

Stratigraphic occurrence. The upper middle Miocene Denticulopsis praedimorpha Zone (NPDSB) through lower Quaternary (Rhizosolenia curvirostris Zone, NPD11).

Description and observations. Valve is a heavily silicified, cylindrical long tube without a terminal external process (sensu Hasle, 1975), almost structureless by LM observations, and curved to varying degrees. Distal end of valve has flattened top plate, which is ovate to elliptical in outline, with conspicuous spines ("barb") at both ends of the top plate (Plate 44, Figs. 3, 6, 8). The rest of the periphery is dentate or with short spines. Central part of the top plate is slightly depressed. Most of the valve face is hyaline and structureless, but two kinds of striations are clearly discernible by SEM. First, several long longitudinal rows of striae line both the dorsal and ventral sides of valve (Plate 44, Figs. 3, 5, 7), and terminate at a short distance from apex. Second, several rows of short longitudinal striae are restricted to near apex of the valve and are positioned between the longer rows of striae (Plate 44, Figs. 5, 7). A short slit, elongated longitudinally, occurs at one side of valve near the apex, very close to the top plate (Plate 44, Fig. 4).

Remarks. This species resembles Rhizosolenia curvirostris, but is easily distinguished from it by the lack of a broad dorsal spine near the maximum curvature of valve.

Morphologies and biostratigraphic distributions of this taxon and its related two taxa, $R$. praebarboi Schrader and $R$. curvirostris Jousé are well known (Brun, 1894; Jousé, 1968, 1971; Donahue, 1970; Schrader, 1973a; Barron, 1980a). It is a common understanding that the three species form a continuous evolutional lineage, starting from $R$. praebarboi, through $R$. barboi, and ending with $R$. curvirostris. All are extinct. A SEM photo of $R$. barboi (Sancetta, 1984) reveals the morphology described above, although the long striae along both the dorsal and ventral sides of valve and the slit near apex were not mentioned in the accompanying text. Sancetta (1984) stressed the close morphologic and phylogenetic similarity of the three extinct species to an extant species, $R$. alata Brightwell, a species documented in detail by Hasle (1975).

Rhizosolenia curvirostris Jousé

(Plate 42, Figs. 1-2; Plate 45, Fig. 1-6)

Original description. Jousé, 1968, p. 19, pl. 3, fig. 2.

Type locality. North Pacific basin sediment.

Stratigraphic occurrence. Common to abundant from lower part of Quaternary Actinocyclus oculatus Zone (NPD10) through the top of Rhizosolenia curvirostris Zone (NPD11). The last occurrence defines the top of the latter zone.

Description and observations. Valve is heavily silicified, cylindrical and hollow, more or less strongly curved, and somewhat twisted in cases, without a terminal external process. Valve is almost hyaline, and only obscure maculations are sometimes seen with LM. Distal end of valve terminates with flattened top plate, which is long and elliptical in outline, with conspicuous spines at both ends (Plate 45, Fig. 1-2, 4, 6 ). The dorsal of the two spines is almost parallel to the top plate and the ventral nearly perpendicular to it. The rest of the periphery of the top plate is dentate. A peculiar triangular or bi-triangular broad and flattened spine, which is very similar in shape to the dorsal fin of sharks, is present at dorsal side near the maximum curvature of valve (Plate 42, Figs. 1-2; Plate 45, Figs. 1-5). As with $R$. barboi two kinds of longitudinal rows of striae are observed, but these are heavily etched by dissolution and as a result so are most of the punctae of the striae (Plate 45, Figs. 3, 5-6). A small slit elongated longitudinally near the apex is clearly observed (Plate 45, Fig. 6).

Remarks. This species is similar to $R$. barboi, but is easily distinguished from it by the conspicuous triangular to bi-triangular broad spine near the maximum curvature of valve, and by its curvature, which is, in general, more pronounced than that of $R$. barboi.
Rhizosolenia praebarboi Schrader

(Plate 42, Figs. 8-9; Plate 43, Figs. 1-9)

Original description. Schrader, 1973a, p. 709, pl. 24, figs. 1-3. Type locality. DSDP Leg 18 , Sample $173-22-1,10-11 \mathrm{~cm}$, northeastern Pacific, off northern California.

Stratigraphic occurrences. Rare in lower Miocene Thalassiosira fraga Zone (NPD2) through upper Miocene Denticulopsis dimorpha Zone (NPD5D).

Observations. Valve almost straight, but slightly bent near the apex without a terminal process (Plate 42, Fig. 8; Plate 43, Fig. 9). The distal end of valve has a flattened, elliptical-to-linear top plate, with a distinctly dentate periphery (Plate 43, Figs. 3-5). There are 5-6 long, longitudinal rows of fine puncta on both sides of valve (Plate 43, Figs. $1-2,8)$, and another several short rows forming triangular areas near the apex (Plate 43, Figs. 4-7). A small, longitudinally elongated slit is located at one of the areas (Plate 43, Figs. 3-7).

Remarks. This species is similar to $R$. barboi, but is distinguished from it by an almost straight valve and the lack of spines at both api$\mathrm{cal}$ ends of the top plate of the valve. Distinctions between the two species, however, are difficult in some cases, especially near the horizon of the first occurrence of $R$. barboi, because specimens that are morphologically intermediate between the two forms are encountered. This species is also similar to $R$. interposita Hajós (1976, p. 827, pl. 21, fig. 8; Plate 42, Fig. 6), which rarely occurs in the lower Miocene $T$. fraga Zone (NPD2) and also in the Cricidenticula kanayae Zone (NPD3A), but it is distinguished from it by its straight valve.

\section{Rouxia californica M. Peragallo}

(Plate 46, Figs. 1-5, 11; Plate 47, Figs. 1-11)

Tempère and Peragallo, 1910, p. 245; Hanna, 1930, p. 186, pl. 14, figs. 6-7.

Stratigraphic occurrence. Common in upper Miocene Denticulopsis katayamae Zone (NPD6A) through $R$. californica Zone (NPD7A), although it rarely occurs in older and younger horizons. The last common occurrence of this species defines the top of $R$. californica Zone, and its last occurrence approximates the Miocene/Pliocene boundary (Fig. 1).

Observations. Both marginal and central apical rows of elongated "beads" (Hanna, 1930) or puncta on the valve face look structurally similar by LM observations (Plate 46 , Figs. 1-5, 11). SEM observations, however, show that their structures are different. The central rows of puncta are not true puncta, but depressions on the valve face (Plate 47, Figs. 3-4, 7-8), which do not penetrate into the valve interior (Plate 47, Figs. 1-2, 5). They extend from center to near one apex, but stop at the middle part of raphe toward the other apex (Plate 47, Fig. 3). The marginal rows of puncta are real but are interrupted by somewhat irregular apical structures and are occluded by rotae (Plate 47, Figs. 6-7). The valve mantle has a row of puncta (Plate 47, Fig. 6) and a marginal ridgelike elevation is present between the mantle and the valve face (Plate 47, Figs. 3-4).

Remarks. The current specific concept of this species is seemingly based on the description and figures presented by Hanna (1930), who reviewed in detail all four species of the genus known at that time, because the original description (Tempère and Peragallo, 1910) is very short and lacks illustrations. It is generally understood that this species is similar to $R$. peragalli Brun and Héribaud (Hanna, 1930, p. 180, pl. 14, figs. 1-5) but is distinguished from it by dense punctae over almost the entire valve face and also by generally longer valve. Those diagnoses, however, are not sufficient to distinguish the two species, because several specimens are not identified precisely in the material examined (Plate 46, Figs. 6-7, 12; Plate 47, Fig. 10).

After the work of Hanna (1930), many new species of the genus were described and 17 species are known presently. The specific concepts and diagnoses of some of these species, however, also remain unclear, partly because of the poor understanding of their real structures.

\section{Thalassionema hirosakiensis (Kanaya) Schrader}

(Plate 48, figs. 6-9, 13-14; Plate 49, Figs. 1-8)

Schrader, 1973a, p. 711, partly; Akiba et al., 1982, pl. 3, fig. 81; Akiba, 1982a, p. 49, pl. 1, figs. 1-5. 
Synonym. Fragilaria hirosakiensis Kanaya, 1959, p. 104, pl. 9, figs. 11a-14, not Hajós, 1968, pl. 44, figs. 17-19, 21-29; not Thalassionema hirosakiensis (Kanaya) Schrader, Schrader, 1973a, pl. 23, figs. 31-33; 1976, pl. 1, figs. 14-16; Schrader and Fenner, 1976, pl. 5, figs. 3-4, 6-7,; Barron, 1980a, pl. 2, fig. 6; 1981, pl. 5, fig. 4.

Stratigraphic occurrence. This species ranges from at least the lower middle Miocene Denticulopsis lauta Zone (NPD4A) through the upper Miocene Thalassionema schraderi Zone (NPD6B, Fig. 1). It generally occurs rarely within this interval, but is common within its type horizon, the upper middle Miocene Denticulopsis praedimorpha Zone (NPD5B).

Observations. The labiate processes are situated in the "one per pole pattern" of Simonsen (1979); namely one process is near each apex of the valve (Plate 49, Figs. 3-4). There is a very small pore over each process (Plate 49, Figs. 3-4). The inner slit of process is oblique to midline. The valve face is almost hyaline except for the margin where areolae compose one internal row (Plate 49, Fig. 3) and external double rows of pores (Plate 49, Figs. 1-2). The pores of the external outer row are twice as numerous as those of inner row (Plate 49, Fig. 1). The mantle is relatively high and smooth (Plate 49, Fig. 1).

Remarks. This species resembles both $T$. nitzschioides (Grunow) $\mathrm{H}$. and $\mathrm{M}$. Peragallo and $T$. schraderi Akiba, but differs from the former by closely arranged marginal puncta or areolae, and from the latter by its narrower valve.

Schrader (1973a) correctly transferred this species from Fragilaria into Thalassionema, but rather than representing this species, his illustrations instead depict a closely related taxon, T. schraderi Akiba.

\section{Thalassionema schraderi Akiba}

(Plate 48, Figs. 1-5, 10-12; Plate 50, Figs. 1-10)

Akiba, 1982a, p. 50, pl. 1, figs. 6-11, 16-18.

Synonym. Thalassionema hirosakiensis (Kanaya) Schrader, Schrader, 1973a, pl. 23, figs. 31-33; Barron, 1980a, pl. 2, fig. 6; 1981, pl. 5, fig. 4; not Schrader, 1976, pl. 1, figs. 14-16; not Schrader and Fenner, 1976, pl. 5, figs. 3-4, 6-7. Thalassionema hirosakiensis (Kanaya) Schrader s.l., Akiba et al., 1982, pl. 3, figs. 77-80.

Type locality. Sample JDS-5239, Kubo Formation, Ninohe Area, Aomori Prefecture, northeastern Honshu, Japan; upper Miocene ( $T$. schraderi Zone).

Stratigraphic occurrence. Common to abundant in the upper Miocene $T$. schraderi Zone (NPD6B) and its last occurrence defines the top of that Zone (Fig. 1). It also occurs in older horizons down to the Denticulopsis dimorpha Zone (NPD5D), but these occurrences are extremely rare to sporadic in NPDSD.

Observations. There are two labiate processes on a valve, in a pattern of "one per pole" with a small pore over each (Plate 50, Figs. 2-3, $5)$. The valve face is almost hyaline. The areolae are restricted to the valve margin, consisting of an internal single row (Plate 50, Fig. 8) and external double rows of pores (Plate 50, Figs. 4-7, 10). The pores of external outer rows are twice as numerous as those of inner rows (Plate 50, Fig. 6). Remnants of rotae are visible in well-preserved specimens (Plate 50, Figs. 7, 9-10). The mantle is high and smooth (Plate 50, Fig. 1).

Remarks. This species resembles T. hirosakiensis (Kanaya) Schrader and Thalassiothrix robusta (Schrader) Akiba (this volume), but is easily distinguished from both by a much broader valve and the acuminated ends of the axial area, and from the latter by its linear rather than lanceolate shape. Akiba (1982a) noted that confusion of this species with both Thalassionema nitzschioides and $T$. hirosakiensis has caused a long neglect of its utility in stratigraphic zonation. Because its valve is very heavily silicified, this species is one of the most dissolution resistant among Neogene diatoms, even occurring in strongly dissolved assemblages such as those cored at DSDP Leg 19 sites (Akiba, this volume).

This species is also occasionally identified as Synedra jouseana $\mathrm{f}$. linearis Sheshukova-Poretzkaya (Schrader, 1976; Schrader and Fenner, 1976, as T. hirosakiensis) because both species have similar valve outlines and are heavily silicified, but the latter is easily distinguished from $T$. schraderi by two apical lines in the valve center.

\section{Thalassiosira antiqua (Grunow) Cleve-Euler}

(Plate 51, Figs. 1-2, 4; Plate 52, Figs. 1-9)

Cleve-Euler, 1951, p. 72, figs. 119a-k; Sheshukova-Poretzkaya, 1967, p. 143 , pl. 14, figs. 3a-b; Koizumi, 1973b, p. 834, pl. 7, fig. 12;
Schrader, 1973a, pl. 11, fig. 25, pl. 25, fig. 19; Barron, 1980a, pl. 5, fig. 5 .

Stratigraphic occurrence. Rare to frequent from the upper upper Miocene (upper part of Thalassionema schraderi Zone, NPD6B) through the upper Pliocene (Neodenticula koizumii Zone, NPD9). Its last occurrence defines the top of the $N$. koizumii Zone (Fig. 1).

Description and observations. The valve is circular in outline; the face is almost flat with a slightly concave center. The mantle is shallow and slanting, ending at an almost horizontal ribbed brim. The diameter of specimens is $17-47 \mu \mathrm{m}$. The areolae are basically hexagonal in outline with external circular foramina (Plate 52, Figs. 1-2, 4-5, 9). The internal cribra are circular in outline with fine porelli (Plate 52, Figs. 3, 7-8). The areolae of the valve face are arranged in an eccentric pattern with 6-7 eccentric centers, decreasing slightly in size toward the margin; 5-7 areolae in $10 \mu \mathrm{m}$ in the center to 6-9 in $10 \mu \mathrm{m}$ near the mantle. The areolae of mantle are smaller and more irregular in arrangement than those of valve face. The brim, 1.6-1.8 $\mu \mathrm{m}$ wide, is striated or ribbed, 10 ribs in $10 \mu \mathrm{m}$. A single labiate process is located somewhat inside the ring of marginal strutted processes (Plate 52, Figs. 1, 3, 5-6, 9). It has a prominent external tube and an internal lipshaped slit oriented radially (Plate 52, Fig. 7). A ring of marginal strutted processes is situated in the mantle, 12 processes in $10 \mu \mathrm{m}$ (Plate 52, Figs. 1-2). It is interrupted at two points: one at the labiate process and the other $165^{\circ}$ apart from the labiate process (" $L$ " and " $\mathrm{X}$ " in Plate 52, Figs. 1, 3, 9). Each strutted process has four internal struts and satellite pores (Plate 52, Fig. 7), and a very short external tube, which is often indistinct. A central area consisting of 13-31 strutted processes is surrounded by 6-7 large areolae forming a clear rosette (Plate 52, Figs. 4, 8). Each strutted process of rosette has three struts and satellite pores, and a small outer opening without a tube. Tubular occluded processes form a less regular ring inside the ring of strutted processes (Plate 52, Figs. 2, 5). They are variable in number and in spacing.

Remarks. This species is similar to low-latitude to middle-latitude species, Thalassiosira burckliana Schrader (1974a, p. 916, pl. 1, figs. 21-16; pl. 51, fig. 3), but is distinguished from it by much larger size, relatively smaller central area, regular patterns of areolae and central rosette, and a clearly defined and striated margin. $T$. burckliana rarely occurs in Thalassionema schraderi Zone.

Thalassiosira fraga Schrader

(Plate 51, Figs. 5-10; Plate 53, Figs. 1-8)

Schrader and Fenner, 1976, p. 1001, pl. 16, figs. 9-12.

Type locality. Sample $338-14-1,20-21 \mathrm{~cm}$ of DSDP Leg 38, Norwegian Sea.

Stratigraphic occurrence. Common in lower Miocene Thalassiosira fraga Zone (NPD2). Its first occurrence defines the base of the zone (Fig. 1).

Observations. The valve is robust and circular in outline with the convex valve face. The mantle is shallow, ending at the broad horizontal brim. The areolae are circular to hexagonal in outline with external circular foramina (Plate 53, Fig. 4) and internal hexagonal cribra (Plate 53, Fig. 7). The areolae of the valve face are arranged radially in nearly straight rows, $10-11$ areolae in $10 \mu \mathrm{m}$, whereas those of the mantle are smaller and less regular in arrangement (Plate 53, Figs. 3-4).

A single labiate process is located inside the outer ring of strutted processes. It lacks an external tube but has a tangentially oriented lipshaped internal slit (Plate 53, Figs. 5-6).

There are two rings of strutted processes. The outer one is located in the mantle, 4-5 processes in $10 \mu \mathrm{m}$. Each process has a long external tube, about $1.5 \mu \mathrm{m}$ in length, extending away from the brim, with a widened opening (Plate 53, Figs. 3-4). Its internal short extension has six(?) struts and satellite pores. The inner ring of strutted processes is situated one areola inside of the edge of the valve face, about two processes in $10 \mu \mathrm{m}$, with each process occupying the position where one areola might be located (Plate 53, Fig. 3). The strutted process has six internal struts and satellite pores (Plate 53, Fig. 7), and an external small opening without a tube (Plate 53, Fig. 3).

Remarks. This species is similar to Thalassiosira spinosa Schrader (1976, p. 636, pl. 6, figs. 5-7), but is distinguished from it by conspicuous, dense, and short marginal spines (an outer ring of strutted processes) and isolated areolae.

Schrader (in Schrader and Fenner, 1976) in his original description of this species, remarked that placement of most fossil Thalassiosira species (including this species) is problematic until strutted tubli (pro- 
cess) are found by submicroscopic observations. The correct placement of this species in Thalassiosira is verified by our SEM observations. He also wrote of the necessity to test whether resting spores of Thalassiosira do possess strutted tubli (process), possibly because most fossil Thalassiosira species might be represented by resting spores, because they are heavily silicified in general. Using their clonal cultures, Syvertsen (1979) clarified the presence of both strutted processes and internal cribra in spores of several modern Thalassiosira species.

\section{ACKNOWLEDGMENTS}

We are very grateful to Seiichi Komura and Lloyd H. Burckle for their kind and careful reviews of the manuscript, and to Reimer Simonsen, Kōnosuke Sawamura, Hideaki Takano, and Constance Sancetta for their helpful and valuable suggestions on taxonomic problems. We also thank the following persons who kindly gave us their samples or helped us to use them: John A. Barron, Lloyd H. Burckle, Takemasa Ishii, Kazuhiko Kanō, Hiroshi Kitazato, Seiichi Komura, Olivier M. Monthoux, the National Science Foundation, Hiroshi Noda, Tōru Sakamoto, Hideaki Takano, and Shōichi Yamaguchi. We thank also Kōnosuke Sawamura, Yōko Inoue, Haruo Yamazaki, Kōji Wakita, Hidenori Endo, and Kimio Okumura for their variable help and suggestions on scanning electron microscopic observations and operations. Further appreciation is due to Hiromi Miki, Noriko Oka$\mathrm{da}$, and Kikue Gunji for their assistance in preparing plates and typing the manuscript. Rare copies of several classic descriptions of diatoms were made available to us through Constance Sancetta, Kōnosuke Sawamura, and Tsoy Irina Bolisovna. The senior author is grateful to Japan Petroleum Exploration Company, Limited, for allowing him to publish this paper, and to Seijuro Maiya and many others from the company for their constant help and encouragement during the course of the present study.

\section{REFERENCES}

Akiba, F., 1979. The morphologies of Denticula dimorpha and its related species, and the Neogene diatom biostratigraphy of Japan. Bull. Tech. Lab. JAPEX, 22(3):9-50. (In Japanese)

1980. A lower Miocene diatom flora from the Boso Peninsula, Japan, and the resting spore formation of an extinct diatom, Kisseleviella carina Sheshukova-Poretzkaya. Bull. Tech. Lab. JAPEX, 23(2):81-100.

1982a. Taxonomy and biostratigraphic significance of a new diatom, Thalassionema schraderi. Bacillaria, 5:43-61.

$1982 b$. Late Quaternary diatom biostratigraphy of the Bellingshausen Sea, Antarctic Ocean. Rep. Tech. Res. Cen. JNOC, 16:31-74.

Akiba, F., Yanagisawa, Y., and Ishii, T., 1982. Neogene diatom biostratigraphy of the Matsushima Area and its environs, Miyagi Prefecture, Northeast Japan. Bull. Geol. Surv. Jpn., 33(5):215-239. (In Japanese with English abstract)

Anonymous, 1975. Proposals for a standardization of diatom terminology and diagnoses. Nova Hedwigia Beih., 53:323-354.

Bailey, J. W., 1854. Notes on new American species and localities of microscopical organisms. I. Fossil marine Diatomaceae in California. Smithson. Contrib. Knowl., 7(Art. 3):1-16.

Baldauf, J. G., and Barron, J. A., 1980. Actinocyclus ingens var. nodus: a new stratigraphically useful diatom of the circum-North $\mathrm{Pa}$ cific. Micropaleontology, 26(1):103-110.

Barron, J. A., 1980a. Lower Miocene to Quaternary diatom biostratigraphy of Leg 57, off northeastern Japan, Deep Sea Drilling Project. In Scientific Party, Init. Repts. DSDP, 56, 57, Pt. 2: Washington (U.S. Govt. Printing Office), 641-685.

1980b. Upper Pliocene and Quaternary diatom biostratigraphy of the Deep Sea Drilling Project Leg 54, tropical eastern Pacific. In Rosendahl, B. R., Hekinian, R., et al., Init. Repts. DSDP, 54: Washington (U.S. Govt. Printing Office), 455-486.

1981. Late Cenozoic diatom biostratigraphy and paleoceanography of the middle-latitude eastern North Pacific, Deep Sea Drilling Project Leg 63. In Yeats, R. S., Haq, B. U., et al., Init. Repts. DSDP, 63: Washington (U.S. Govt. Printing Office), 507-538.

in press a. Neogene planktic diatom biostratigraphy. In Bolli H. M., and Saunders, J. B. (Eds.), Biostratigraphy by Plankton: New York (Cambridge University Press).

, in press b. Late Eocene to Holocene diatom biostratigraphy of the equatorial Pacific Ocean, DSDP Leg 85. In Mayer, L., They- er, F., et al., Init. Repts. DSDP, 85: Washington (U.S. Govt. Printing Office).

Brun, J., 1891. Diatomées espèces nouvelles marines, fossiles ou pélagiques. Soc. Phys. Hist. Nat. Geneve Mem., 31:1-47.

1894. Espèces nouvelles. Le Diatomiste, 2:72-78, 86-88.

Brun, J., and Tempère, J., 1889. Diatomées fossiles du Japon. Espèces marines and nouvelles des calcaires argileux des Sendai and de Yedo. Soc. Phys. Hist. Nat. Geneve Mem., 30:1-75.

Burckle, L. H., 1972. Late Cenozoic diatom zones from the eastern equatorial Pacific. Nova Hedwigia, 39:217-250.

Castracane degli Antelminelli, F., 1886. The Voyage of the H.M.S. Challenger. Report on the Diatomaceae. Botany 2(I-III), 1: Edinburgh (Ballantyne, Hanson, and Co.) (reprinted 1966).

Cleve-Euler, A., 1951. Die Diatomeen von Schweden und Finnland. K. Svenska Vet.-Akad. Handl., Fjärde Ser. Bd. 2, No. 1.

Donahue, J. G., 1970. Pleistocene diatoms as climate indicators in North Pacific sediments. In Hays, J. D. (Ed.), Geological Investigations of the North Pacific: Boulder, Colorado (Geol. Soc. Am.), Mem. 126:121-138.

Fenner, J., 1979. Cenozoic diatom biostratigraphy of the equatorial and southern Atlantic Ocean. In Supko, P. R., Perch-Nielsen, K., et al., Init. Repts. DSDP, Suppl. to Vols. 38 39, 40, and 41: Washington (U.S. Govt. Printing Office), 491-623.

Fryxell, G. A., and Miller, I., 1978. Chain forming diatoms: three Araphid species. Bacillaria, 1:113-136.

Greville, R. K., 1866. Description of new and rare diatoms. Ser. XVII-XX, Trans. R. Microsc. Soc. London, N. S., 13:1-9, 77-86, $121-130$.

Grunow, A., 1868. Algae. Reise der österreichen Fregatti Novara um die Erde in den Jahren 1857, 1858, 1859, Botan. Theil, 1:1-104.

Hajós, M., 1968. Die Diatomeen der Miozanen Ablagerungen des Matravorlandes. Geol. Hung. Ser. Palaeontol., 37:1-401.

1976. Upper Eocene and lower Oligocene Diatomaceae, Archaeomonadaceae, and Silicoflagellatae in southwestern Pacific sediments, DSDP Leg 29. In Hollister, C. D., Craddock, C., et al., Init. Repts. DSDP, 35: Washington (U.S. Govt. Printing Office), 817-883.

Hanna, G. D., 1930. A revision of genus Rouxia. J. Paleontol., 4(2): 179-188.

1932. The diatoms of Sharktooth Hill, Kern County, California. Proc. Calif. Acad. Sci., 4th Ser., 20:161-263.

Hasle, G. R., 1972. Fragilariopsis Hustedt as a section of the genus Nitzschia Hassall. Nova Hedwigia Beih., 39:111-119.

1975. Some living marine species of the diatom family Rhizosoleniaceae. Nova Hedwigia Beih., 53:99-153.

Hasle, G. R., and Fryxell, G. A., 1977. The genus Thalassiosira: species with a linear areolae array. Nova Hedwigia Beih., 54:15-66.

Hasle, G. R., von Stosch, H. A., and Syvertsen, E. E., 1983. Cymatosiraceae, a new diatom family. Bacillaria, 6:9-156.

Hata, M., and Hasegawa, Y., 1970. Tertiary geology and diatom flora at southern area of the Okushiri Island off Hokkaido, Japan. Earth Sci. (Chikyu Kagaku), 24(3):93-103. (In Japanese with English abstract)

Jousé, A. P., 1968. New species of diatom in bottom sediments of the Pacific and the Sea of Okhotsk. Nov. Systemat. Plant. Non Vascular: Moskow (Nauka, Acad. Nauk S. S. S. R.), 3:12-21.

, 1971. Diatoms in Pleistocene sediments from the northern Pacific Ocean. In Funnel, B. M. and Riedel, W. (Eds.), Micropaleontology of the Oceans: New York (Cambridge University Press), pp. 407-422.

(Ed.), 1977. Atlas of Microorganisms in Bottom Sediments of the Oceans: Diatoms, Radiolaria, Silicoflagellates, and Coccolithus: Moscow (Nauka).

Jousé, A. P., Petrushevskaya, M. G., Strelnikova, N. I., Dzinoridge, R. N., Ignatova, G. V., Lukina, T. G., Koltun, B. M., Golilkova, G. S., Nagaeva, G. S., and Kozlova, G. E., 1979. The history of the microplankton of the Norwegian Sea on the Deep Sea Drilling material. Explorations of the Fauna of the Seas (Vol. 33): Moscow (Acad. Sci., U.S.S.R. Zool. Inst., Nauka). (In Russian)

Kanaya, T., 1959. Miocene diatom assemblages from the Onnagawa Formation and their distribution in the correlative formations in northeast Japan. Sci. Rep. Tohoku Univ., Ser. 2, 30:1-130.

Kanaya, T., 1971. Some aspects of pre-Quaternary diatoms in the ocean. In Funnell, B., and Riedel, W. (Eds.), Micropaleontology of the Oceans: New York (Cambridge University Press), pp. 545-565. 
Kanaya, T., and Koizumi, I., 1970. The progress in the younger Cenozoic diatom biostratigraphy in the northern Circum-Pacific Region. J. Mar. Geol., 6(2):47-66. (In Japanese with English abstract)

Koizumi, I., 1968. Tertiary diatom flora of Oga Peninsula, Akita Prefecture, northeast Japan. Sci. Rep. Tohoku Univ., Ser. 2, 40(3): 171-225.

1973a. The stratigraphic ranges of marine planktonic diatoms and diatom biostratigraphy in Japan. Mem. Geol. Soc. Jpn., $8: 35-44$.

, 1973b. The late Cenozoic diatoms of Sites 183-193, Deep Sea Drilling Project. In Creager, J. S., Scholl, D. W., et al., Init. Repts. DSDP, 19: Washington (U.S. Govt. Printing Office), 805-855.

1975. Neogene diatoms from the northwestern Pacific Ocean, Deep Sea Drilling Project. In Larson, R. L., Moberly, R., et al., Init. Repts. DSDP, 32: Washington (U.S. Govt. Printing Office), 865-889.

1977. Diatom biostratigraphy in the North Pacific Region. In Saito, T., and Ujiie, H. (Eds.), Proc. First Int. Cong. Pacific Neogene Stratigraphy, Tokyo 1976: Tokyo (Kaiyo-Shuppan), pp. 235-253.

1980. Neogene diatoms from the Emperor Seamount Chain, Leg 55, Deep Sea Drilling Project. In Jackson, E. D., Koizumi, I., et al., Init. Repts. DSDP, 55: Washington (U.S. Govt. Printing Office), 387-407.

Komura, S., 1976. Sawamuraia, Katahiraia und Yoshidaia, drei neue Diatomgattungen aus dem Neogene Japans. Trans. Proc. Palaeontol. Soc. Jpn., New Ser., 103:379-397.

McCollum, D. W., 1975. Diatom stratigraphy of the Southern Ocean. In Hays, D. E., Frakes, L. A., et al., Init. Repts. DSDP, 28: Washington (U.S. Govt. Printing Office), 515-571.

Maruyama, T., 1984. Miocene diatom biostratigraphy of onshore sequences on the Pacific side of northeast Japan, with reference to DSDP Hole 438A (Part 1). Sci. Rep. Tohoku Univ., Ser. 2, 54(2): 141-164.

Mertz, D., 1966. Mikropalaeontologische und sedimentologische Untersuchung der Pisco Formation Südperus. Palaeontographica, Abt. $B, 118: 1-51$.

Mukhina, V. V., 1979. Diatom assemblages in the south-east Pacific. Nova Hedwigia, 64:463-472.

Rattray, J., 1890. A revision of the genus Actinocyclus Ehrb. J. Quekett Microsc. Club, Ser. 2, 4:137-212.

Reinhold, T., 1937. Fossil diatoms of the Neogene of Java and their zonal distribution, Verh. Geol.-Mijn. bouwkd. Genoot. Ned. Kolon., Geol. Ser., 12:43-133.

Ross, R., Cox, E. J., Karayeva. N. I., Mann, D. G., Paddock, T. B. B., Simonsen, R., and Sims, P. A., 1979. An amended terminology for the siliceous components of the diatom cell. Nova Hedwigia, 64:513-533.

Sancetta, C., 1984. Diatoms from Leg 75, Deep Sea Drilling Project. In Hay, W. W., Sibuet, J.-C., et al., Init. Repts. DSDP, 75: Washington (U.S. Govt. Printing Office), 755-762.

Schmidt, A., et al., 1874-1959. Atlas der Diatomaceenkunde: Leipzig, Berlin (O. R. Reisland). (Begun by Schmidt, A., continued by Schmidt, M., Fricke, F., Heiden, H., Müller, O., and Hustedt, F.)

Schrader, H.-J., 1973a. Cenozoic diatoms from the northeast Pacific, Leg 18. In Kulm, L. D., von Huene, R., et al., Init. Repts. DSDP, 18: Washington (U.S. Govt. Printing Office), 673-797.

, 1973b. Stratigraphic distribution of marine Denticula species in Neogene North Pacific sediments. Micropaleontology, 19(4): 417-430.

1974a. Cenozoic marine planktonic diatom stratigraphy of the tropical Indian Ocean. In Fisher, R. L., Bunce, E. T., et al., Init. Repts. DSDP, 24: Washington (U.S. Govt. Printing Office), 887-967.

, 1974b. Revised diatom stratigraphy of the Experimental Mohole Drilling, Guadalupe Site. Proc. Calif. Acad. Sci., 4th Ser., 39: $517-562$

1976. Cenozoic planktonic diatom biostratigraphy of the southern Pacific Ocean. In Hollister, C. D., Craddock, C., et al., Init. Repts. DSDP, 35: Washington (U.S. Govt. Printing Office), 605-671.

Schrader, H.-J., and Fenner, J., 1976. Norwegian Sea Cenozoic diatom biostratigraphy and taxonomy. In Talwani, M., Udintsev, G., et al., Init. Repts. DSDP, 38: Washington (U.S. Govt. Printing Office), 921-1099.

Semina, G. I., 1956. A new species of genus Denticula KTZ. Notul. Sustemat. e sect. cyptogam. Inst. Botan. nomine V. L. Komarovii Acad. Sci. URRS, 11:82-84. (In Russian)

1981. Morphology and distribution of a tropical Denticulopsis. In Ross, R. (Ed.), Proc. Sixth Symp. Recent and Fossil Diatoms: Koenigstein, West Germany (Otto Koeltz Sci. Publ), pp. 179-190.

Sheshukova-Poretzkaya, V. S., 1962. New and rare Bacillariophyta from diatom suite of North Sakhalin. Study Note, Leningrad University, Ser. Biol., 49:203-211. (In Russian)

1967. Neogene marine diatoms of Sakhalin and Kamchat$k a$. Leningrad (Izd. Leningrad University). (In Russian with English abstract)

Simonsen, R., 1974. The diatom plankton of the Indian Ocean Expedition of R/V "Meteor" 1964-1965. "Meteor" Forschungsergeb., Ser. $D, 19: 1-107$.

1975. On the pseudonodules of the Centric diatoms, or Hemidiscaceae reconsidered. Nova Hedwigia, 52:83-97. 2:9-97 1979. The diatom system: ideas on phylogeney. Bacillaria,

Simonsen, R., and Kanaya, T., 1961. Notes on the marine species of the diatom genus Denticula Kütz. Int. Rev. Gesamten Hydrobiol., 46(4):498-513.

Syvertsen, E. E., 1979. Resting spore formation in clonal cultures of Thalassiosira antarctica Comber, T. nordenskioeldii Cleve, and Detonula confervacea (Cleve) Grun Nova Hedwigia, 64:41-63.

Tempère, J., and Peragallo, H., 1910. Diatomées du Monde Entior (Ed. 2): Arcachon (Grez-sur-Loing, S.-et-M.), pp. 209-256.

Takano, H., 1982. Denticulopsis seminae (Simonsen and Kanaya) Simonsen. In Working Party on Taxonomy in the Akashio Kenkyukai (Ed.), Synopsis of Red-Tide Organisms: Tokyo (Fisheries Agency, Japanese Government), (Sheet No. 105). (In Japanese)

Ujiie, H., Saito, T., Kent, D. V., Thompson, P. R., Okada, H., Klein, G. V., Koizumi, I., Harper, H. E., and Sato, T., 1977. Biostratigraphy, paleomagnetism and sedimentology of late Cenozoic sediments in northeastern Hokkaido, Japan. Bull. Natl. Sci. Mus., Ser. C: Geol. (Tokyo), 3(2):49-102.

Wornardt, W. W., 1967. Miocene and Pliocene marine diatoms from California. Occas. Pap. Calif. Acad. Sci., 63:1-108.

Zabelina, M. M., 1934. Diatoms from the Tertiary deposits of the eastern coast of Kamchatka. Transact. Oil. Geol. Inst., Ser. A, 48: 3-19. (In Russian)

Date of Initial Receipt: 21 March 1984

Date of Acceptance: 20 August 1984

\section{APPENDIX}

List of Diatoms Treated in This Chapter (genera arranged in the order treated and species in alphabetical order)

Crucidenticula $\mathrm{n}$. gen.

C. ikebei $\mathrm{n} . \mathrm{sp}$.

C. kanayae n. sp.

C. nicobarica (Grunow) n. comb.

C. paranicobarica n. sp.

C. punctata (Schrader) n. comb.

Denticula norwegica Schrader

Denticulopsis Simonsen emend.

D. dimorpha (Schrader) Simonsen emend.

$D$. hustedtii (Simonsen and Kanaya) Simonsen

D. hyalina (Schrader) Simonsen

D. katayamae Maruyama

D. miocenica (Schrader) Simonsen

D. praedimorpha Barron ex Akiba

$D$. praelauta Akiba and Koizumi

Neodenticula n. gen.

N. kamtschatica (Zabelina) n. comb.

$N$. koizumii nom. stat. et comb. n.

$N$. seminae (Simonsen and Kanaya) n. comb.

N. sp. A

Thalassiosira brunii comb. et nom. n.

$T$. grunowii nom. et comb. n.

T. temperei (Brun) n. comb. 
T. yabei (Kanaya) n. comb.

Actinocyclus ingens Rattray

A. oculatus Jousé

Kisseleviella carina Sheshukova-Poretzkaya

$K$. ezoensis Akiba

$K$. magnaareolata $\mathrm{n}$. sp.

Nitzschia jouseae Burckle

$N$. miocenica Burckle

N. pliocena (Brun) Mertz
$N$. reinholdii Kanaya ex Schrader

Rhizosolenia barboi (Brun) Tempère and Peragallo

$R$. curvirostris Jousé

$R$. praebarboi Schrader

Rouxia californica M. Peragallo

Thalassionema hirosakiensis (Kanaya) Schrader

T. schraderi Akiba

Thalassiosira antiqua (Grunow) Cleve-Euler

T. fraga Schrader 

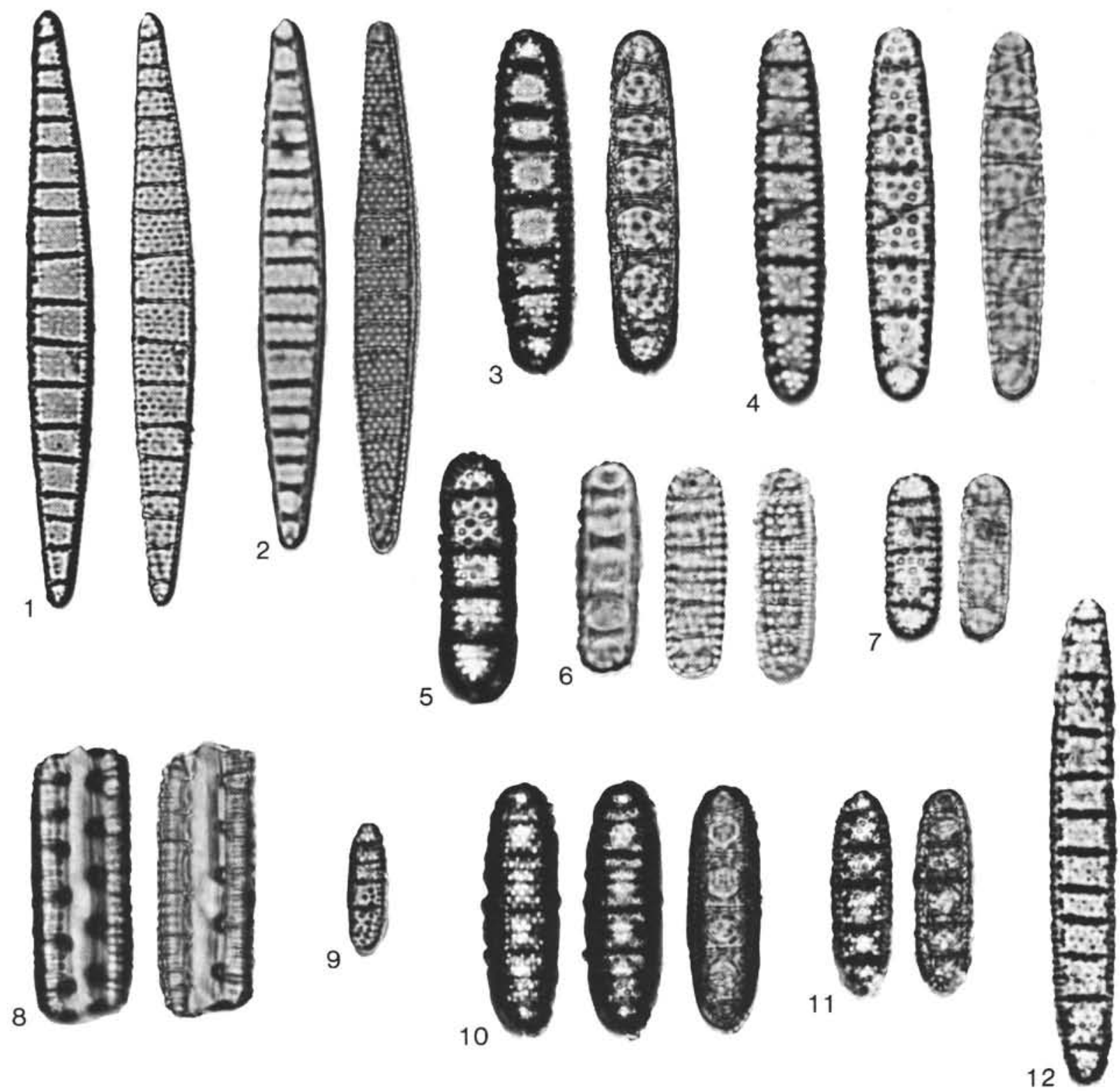

Plate 1. (All specimens magnified $\times 1500$.) 1-2. Crucidenticula ikebei Akiba and Yanagisawa n. sp., Sample JDS-5675, Tsurikake Formation, Okushiri Island, southern Hokkaido, (1) holotype, (2) inner valve view. 3-4, 6-8. Crucidenticula kanayae Akiba and Yanagisawa n. sp., Sample JDS-5676, Tsurikake Formation, Okushiri Island, southern Hokkaido, (3) holotype, (4) paratype, (8) girdle view of a frustule. 5. Crucidenticula kanayae Akiba and Yanagisawa, n. sp., Sample JDS-4134, Hojuji Formation, Noto Peninsula, central Japan. 9. Crucidenticula nicobari$c a$ (Grunow) Akiba and Yanagisawa n. comb., Sample 584A-H4,CC. 10-12. Crucidenticula punctata (Schrader) Akiba and Yanagisawa n. comb., (10) Sample JDS-11921, Isozaki Formation, Ajigaura Area, northeastern Honshu, (11) Sample JDS-11193, Mito Formation, Mito City, eastern Honshu, (12) Sample JDS-6573, Iizuka Formation, Noto Peninsula, central Japan. 

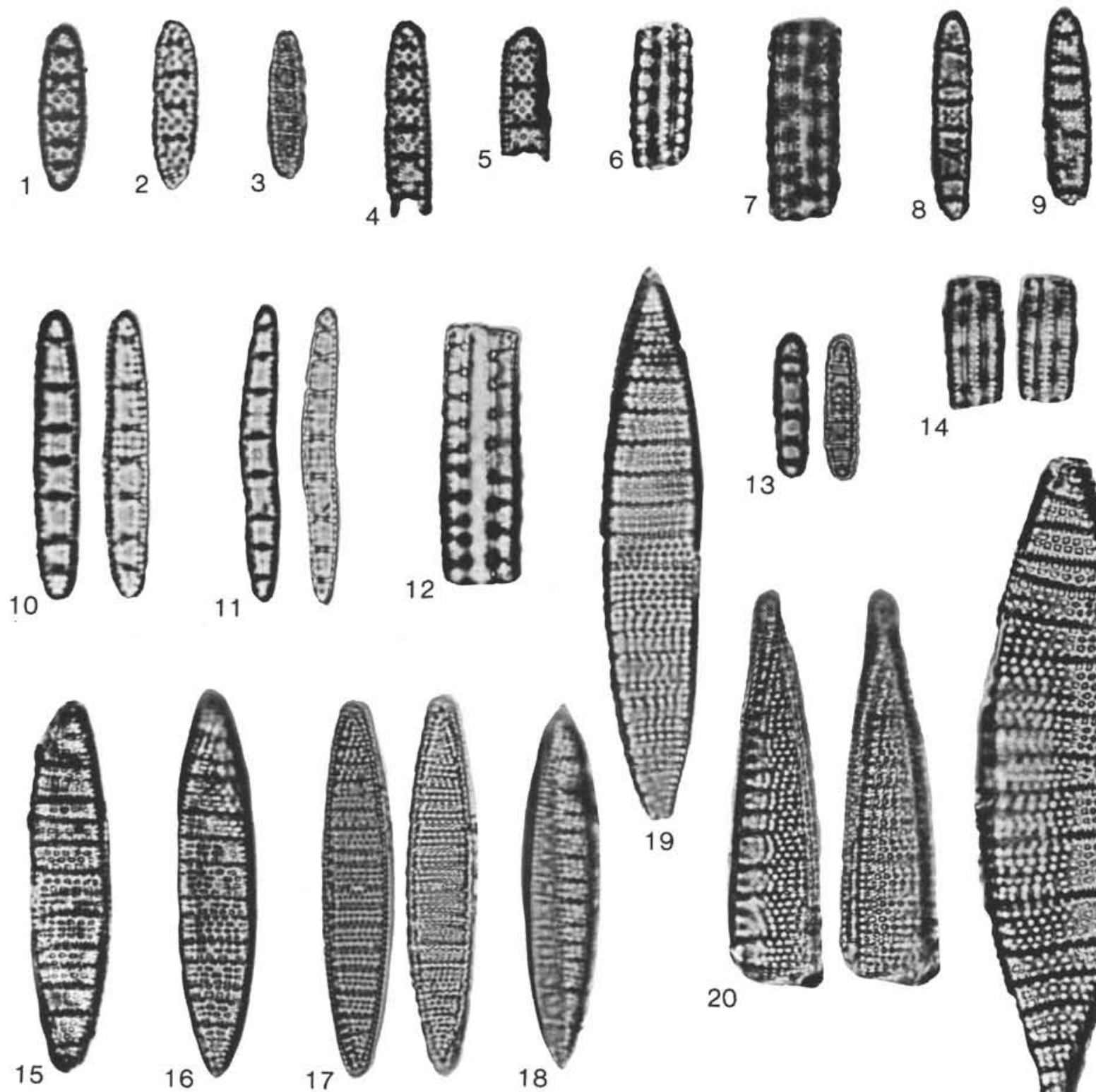

$$
14
$$
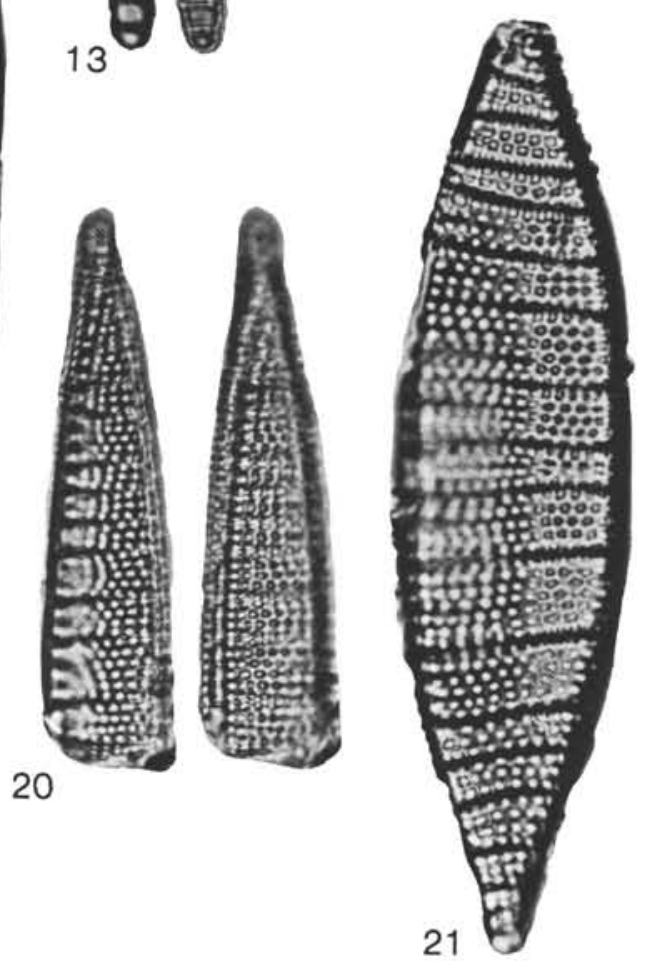

Plate 2. (All specimens magnified $\times 1500$.) 1-7. Crucidenticula nicobarica (Grunow) Akiba and Yanagisawa n. comb., (1) Sample JDS-4118, Iida Formation, Noto Peninsula, central Japan, (2) Sample JDS-4156, Sugata Formation, Noto Peninsula, central Japan, (3-6) Sample 584AH4,CC (6, girdle view of a frustule), (7) Sample 584-94-1, 69-70 cm, girdle view of a frustule. 8-14. Crucidenticula paranicobarica Akiba and Yanagisawa n. sp., $(8-9,13,14)$ Sample JDS-11407, an exotic block in Atsunai Formation, Atsunai Area, eastern Hokkaido, (10-11) Sample JDS-4685, Masuporo Formation, Tenpoku Area, northern Hokkaido (10, holotype), (12) Sample JDS-4686, Masuporo Formation, girdle view of a frustule. 15-21. Denticula norwegica Schrader, $(15,20)$ Sample JDS-11171, Matsushima Formation, Matsushima Area, northeastern Honshu (20, inner valve view), (16) Sample JDS-11833, lower part of Taga Group, Joban Area, northeastern Honshu, (17, 21) Sample JDS-5676, Tsurikake Formation, Okushiri Island, southern Hokkaido (21, an exceptionally large form), (18) Sample JDS-5675, Tsurikake Formation, (19) Sample JDS-4136, Hojuji Formation, Noto Peninsula, central Japan. 

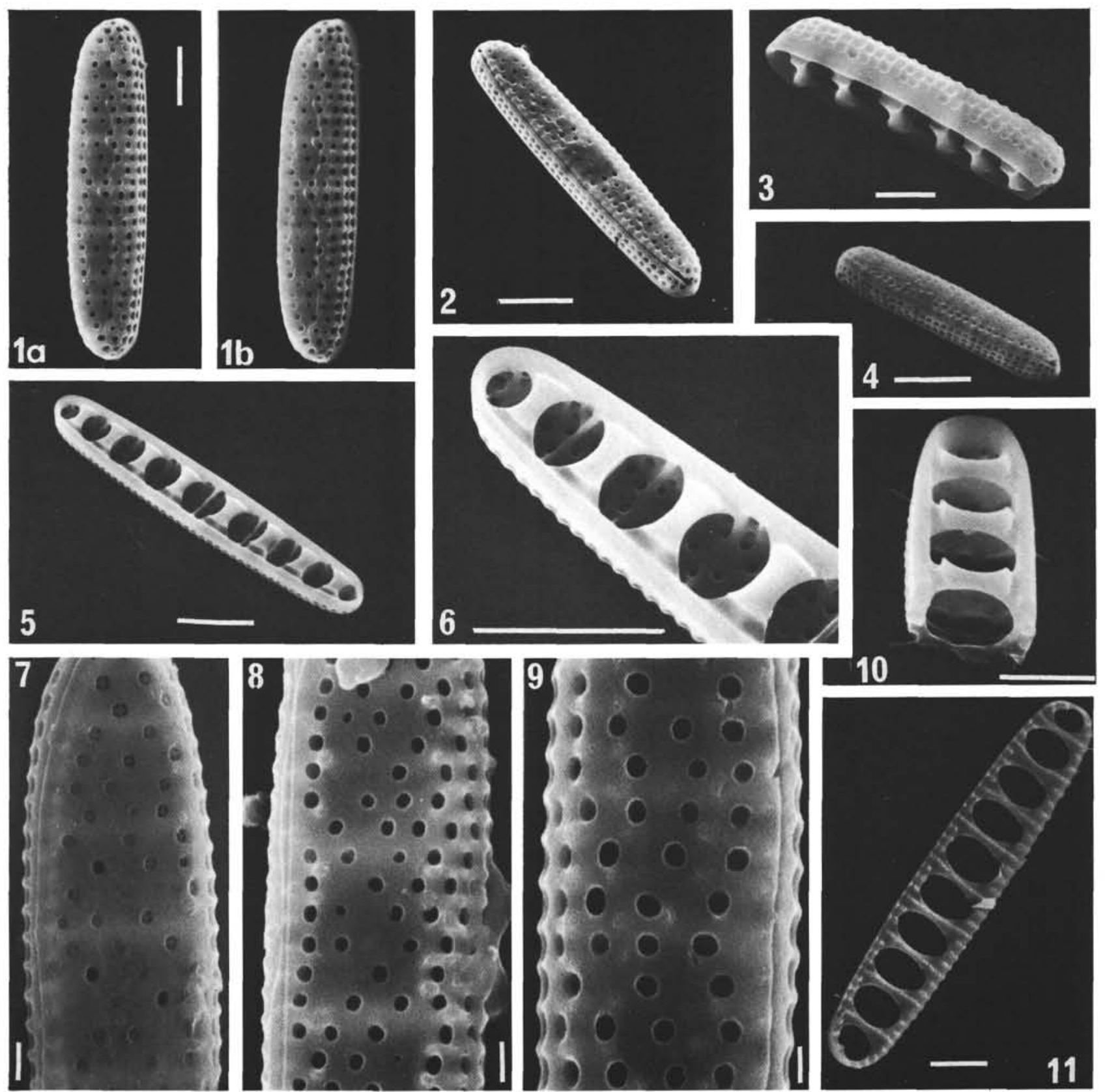

Plate 3. (Scale bar $=5 \mu \mathrm{m}$ unless otherwise indicated.) 1-6, 9-11. Crucidenticula kanayae Akiba and Yanagisawa n. sp., Sample JDS-9707, Tsurikake Formation, Okushiri Island, southern Hokkaido, (1A-B) external views of valve (stereoscopic pair), (2) oblique view of valve exterior (bar $=10 \mu \mathrm{m}$ ), (3) oblique girdle view of valve, (4) oblique view of valve exterior (bar $=10 \mu \mathrm{m}$ ), (5) oblique view of valve interior (bar $=10 \mu \mathrm{m})$, (6) detail of apex of specimen shown in Figure $5(\mathrm{bar}=10 \mu \mathrm{m})$, (9) outer surface of valve face; note outer slit of raphe divided $(\mathrm{bar}=1 \mu \mathrm{m}),(10)$ interior of broken valve, (11) advalvar surface of deck of broken valve. 7. Crucidenticula nicobarica (Grunow) Akiba and Yanagisawa $\mathrm{n}$. comb., Sample JDS-10242, outer surface of valve face $(\mathrm{bar}=1 \mu \mathrm{m})$. 8. Crucidenticula punctata (Schrader) Akiba and Yanagisawa n. comb., Sample JDS-11921, outer surface of valve face $(\mathrm{bar}=1 \mu \mathrm{m})$

Note: In this and the following plates, uppercase letters in the captions refer to the same lowercase letters in the plate labels. 

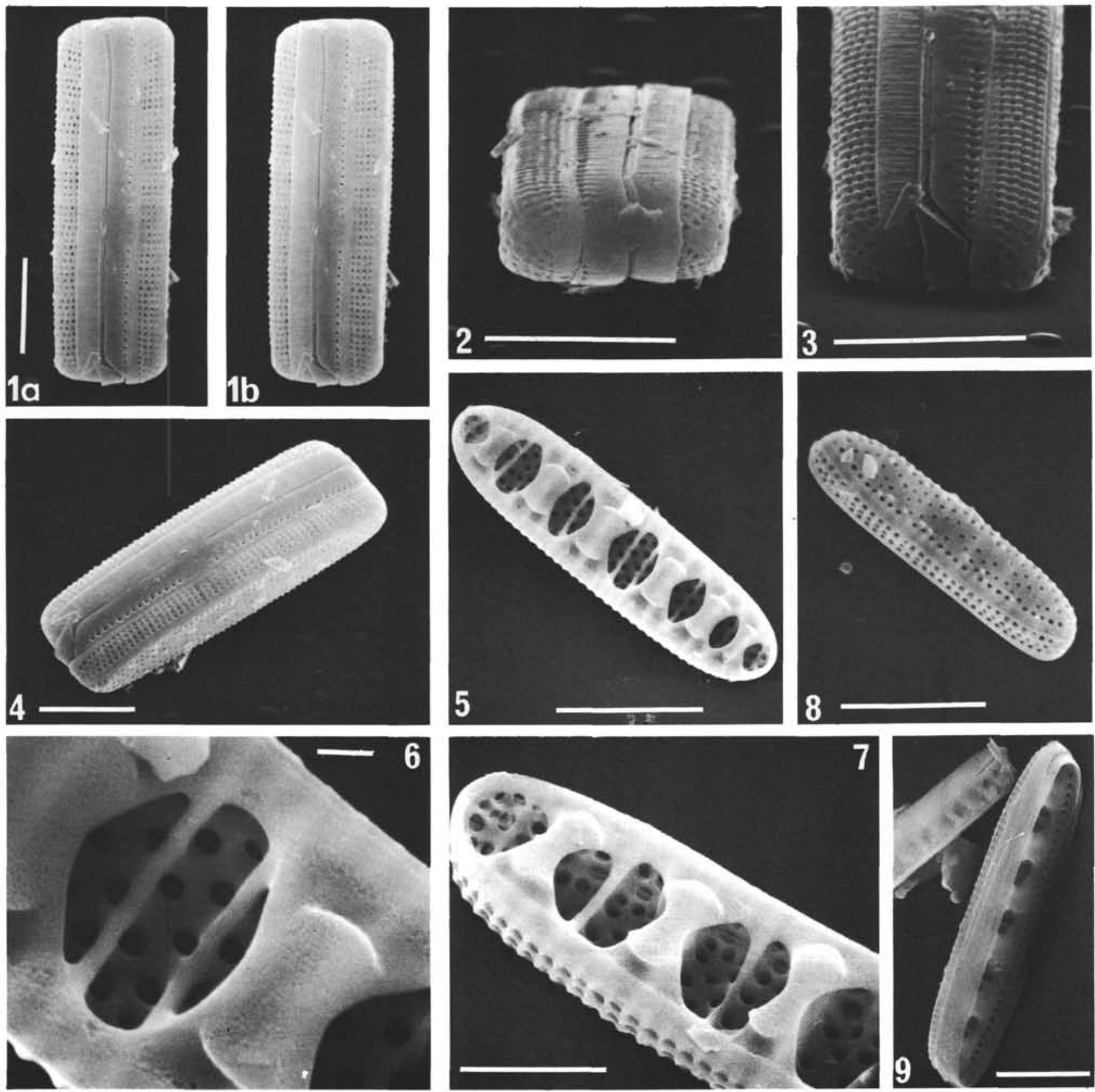

Plate 4. (Scale bar $=10 \mu \mathrm{m}$ unless otherwise indicated.) Crucidenticula punctata (Schrader) Akiba and Yanagisawa n. comb., Sample JDS-11921, Isozaki Formation, Ajigaura Area, northeastern Honshu. 1A-B. Girdle views of frustule (stereoscopic pair). 2. Narrow girdle view of specimen shown in Figure 1. 3. The other apex of specimen shown in Figure 2; note open copula, narrow first pleura, and broad second pleura. 4. Oblique view of specimen shown in Figure 1. 5 Internal view of valve. 6. Enlarged view of middle portion of specimen shown in Figure 5; note areolae with cross-shaped rotae, bar $=1 \mu \mathrm{m}$. 7. Oblique view of specimen shown in Figure 5; note circular portulae, bar $=5 \mu \mathrm{m}$. 8 . Oblique view of valve exterior. 9. Oblique view of valve with cingulum. 

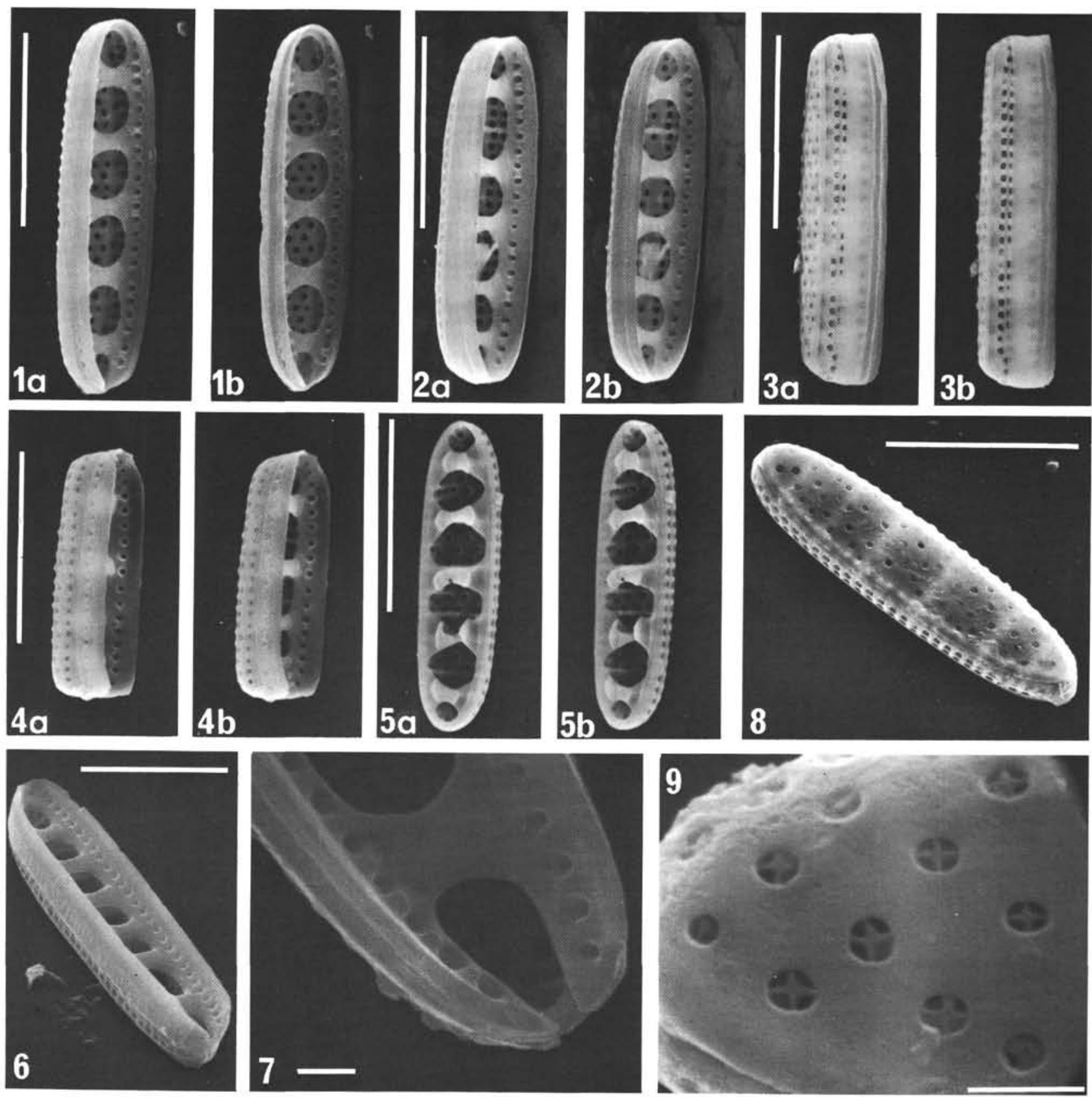

Plate 5. (Scale bar $=10 \mu \mathrm{m}$ unless otherwise indicated.) Crucidenticula nicobarica (Grunow) Akiba and Yanagisawa n. comb., Sample JDS-10242,

Hataya Formation, Matsushima Area, northeastern Honshu. 1A-B. Internal views of hypovalve with copula covered with pleura of epitheca (stereoscopic pair). 2A-B. Oblique internal views of hypovalve with copula covered with pleura of epitheca (stereoscopic pair). 3A-B. Girdle views of specimen shown in Figures 2A-B (stereoscopic pair). 4A-B. Oblique girdle views of small valve with copula (stereoscopic pair). 5A-B. Internal views of valve (stereoscopic pair). 6. Oblique internal view of hypovalve with copula covered with pleura of epitheca. 7. Enlarged view of apical part of specimen shown in Figure $6(\mathrm{bar}=1 \mu \mathrm{m})$. 8. External view of valve. 9. Areolae with cross-shaped rotae $(\mathrm{bar}=1 \mu \mathrm{m})$. 

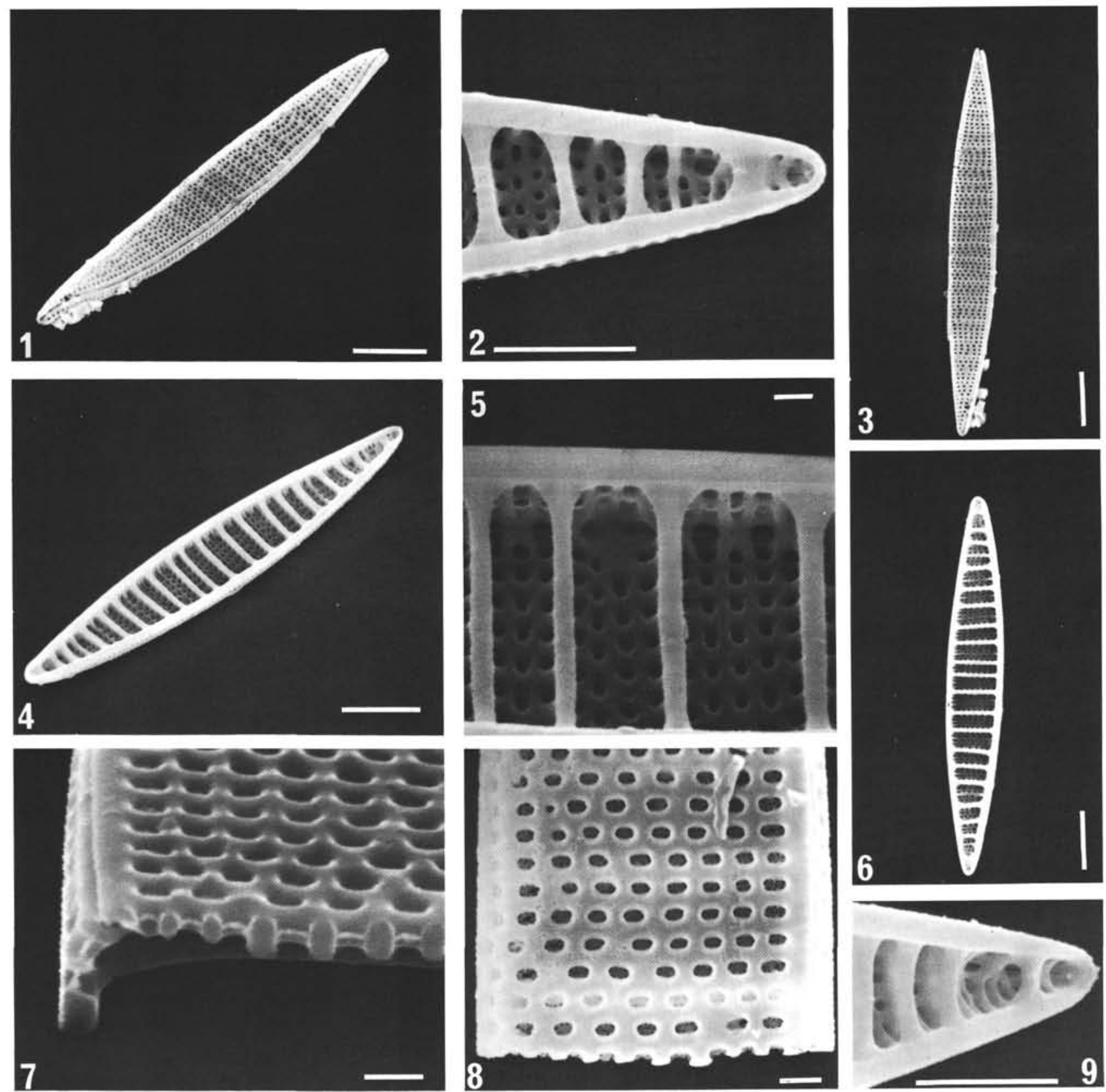

Plate 6. Denticula norwegica Schrader, Sample JDS-11171, Matsushima Formation, Shiogama Area, northeastern Honshu. 1. Oblique external view of valve $(\mathrm{bar}=10 \mu \mathrm{m})$. 2. Internal view of apical part of valve $(\mathrm{bar}=5 \mu \mathrm{m})$. 3. Valve exterior $(\mathrm{bar}=10 \mu \mathrm{m})$. 4. Oblique internal view of valve $(\mathrm{bar}=10 \mu \mathrm{m})$. 5. Middle part of valve interior $(\mathrm{bar}=1 \mu \mathrm{m})$. 6. Valve interior $(\mathrm{bar}=10 \mu \mathrm{m})$. 7. Valve wall of broken specimen $($ bar $=1 \mu \mathrm{m})$. 8. Areolae of valve face $(\mathrm{bar}=1 \mu \mathrm{m})$. 9. Internal view of apex of valve $(\mathrm{bar}=5 \mu \mathrm{m})$. 

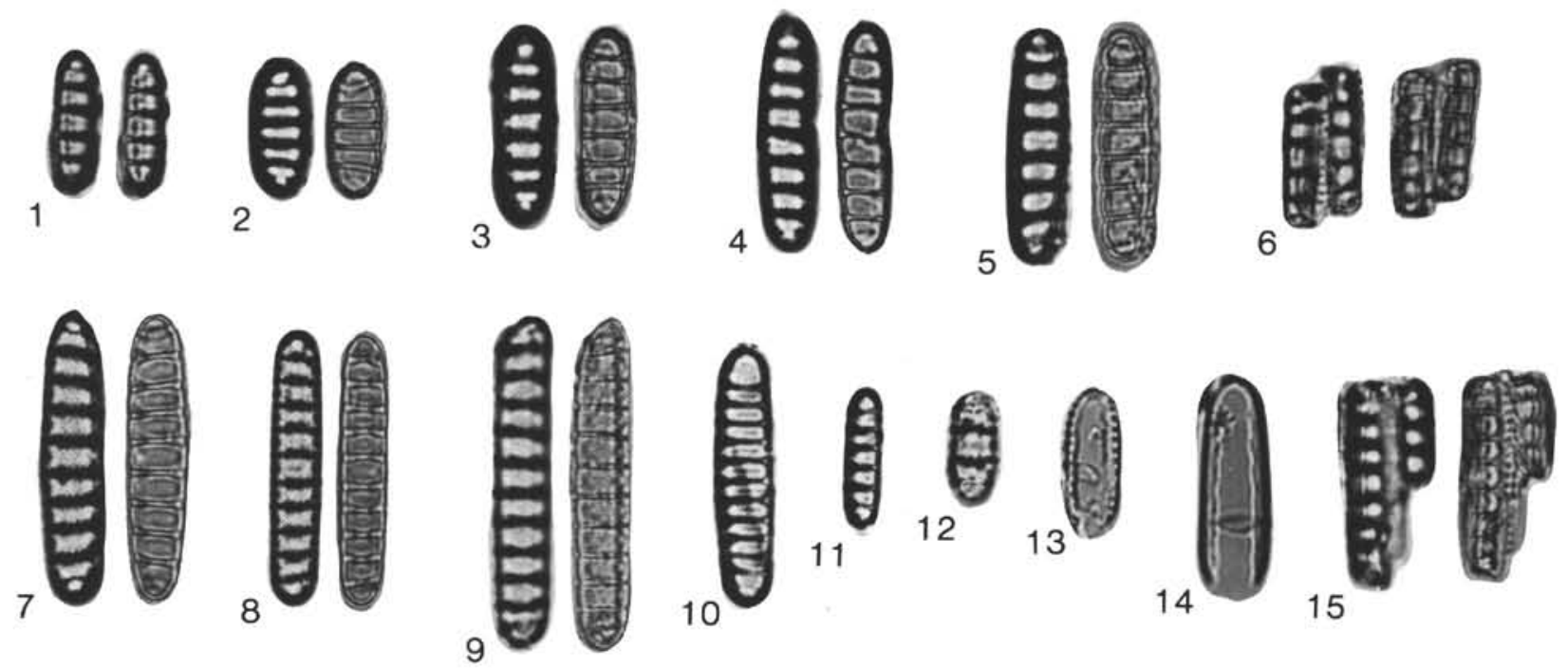
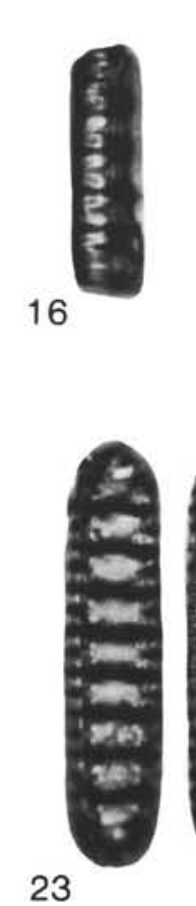

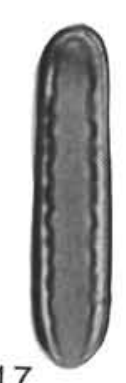

\section{8}

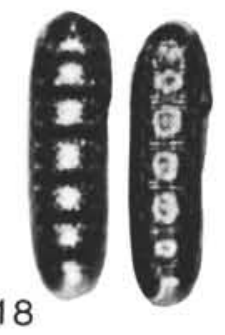

19
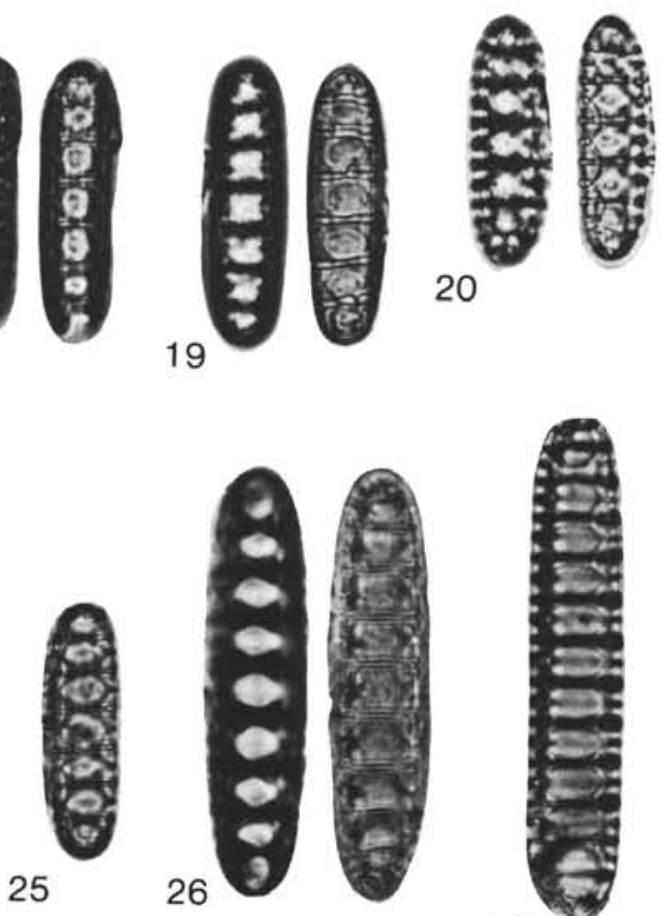
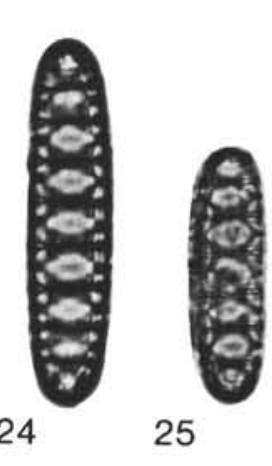

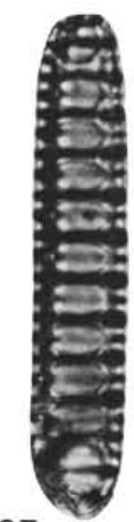

27
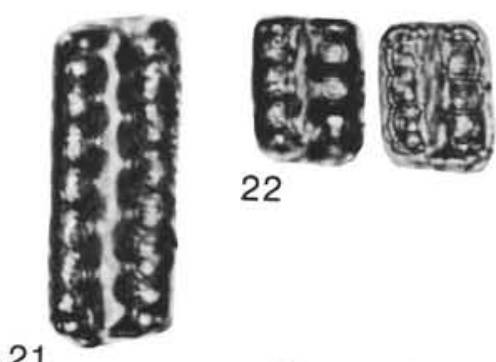

22

21

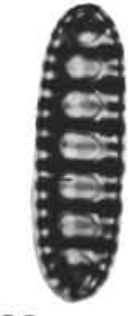

28
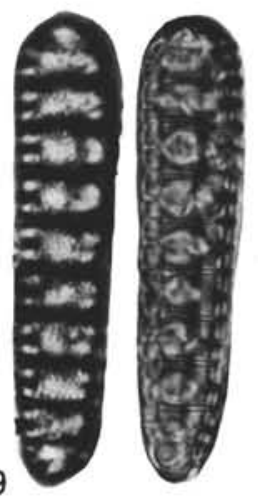

Plate 7. (All specimens magnified $\times 1500$.) 1-15. Denticulopsis praelauta Akiba and Koizumi, $(1-6,15)$ Sample 439-8-6, 49-52 cm, type material of the species $(6,15$, girdle view of a frustule), (7-9) Sample JDS-11833, lower part of Taga Group, Joban Area, northeastern Honshu, (10-11) Sample JDS-11166, Matsushima Formation, Matsushima Area, northeastern Honshu, (12-14) Sample JDS-11159 from the same formation as Figures 10-11 (13-14, isolated copulae). 16-29. Denticulopsis lauta (Bailey) Simonsen, (16-17, 23-29) Sample JDS-11407, an exotic block in Atsunai Formation, Atsunai Area, eastern Hokkaido (16, girdle view of a valve; 17, isolated copula; 26-28, inner valve view of a valve; 29, aberrant form), (18-22) Sample 438A-70-7, 5-7 cm (21-22, girdle view of a frustule). 

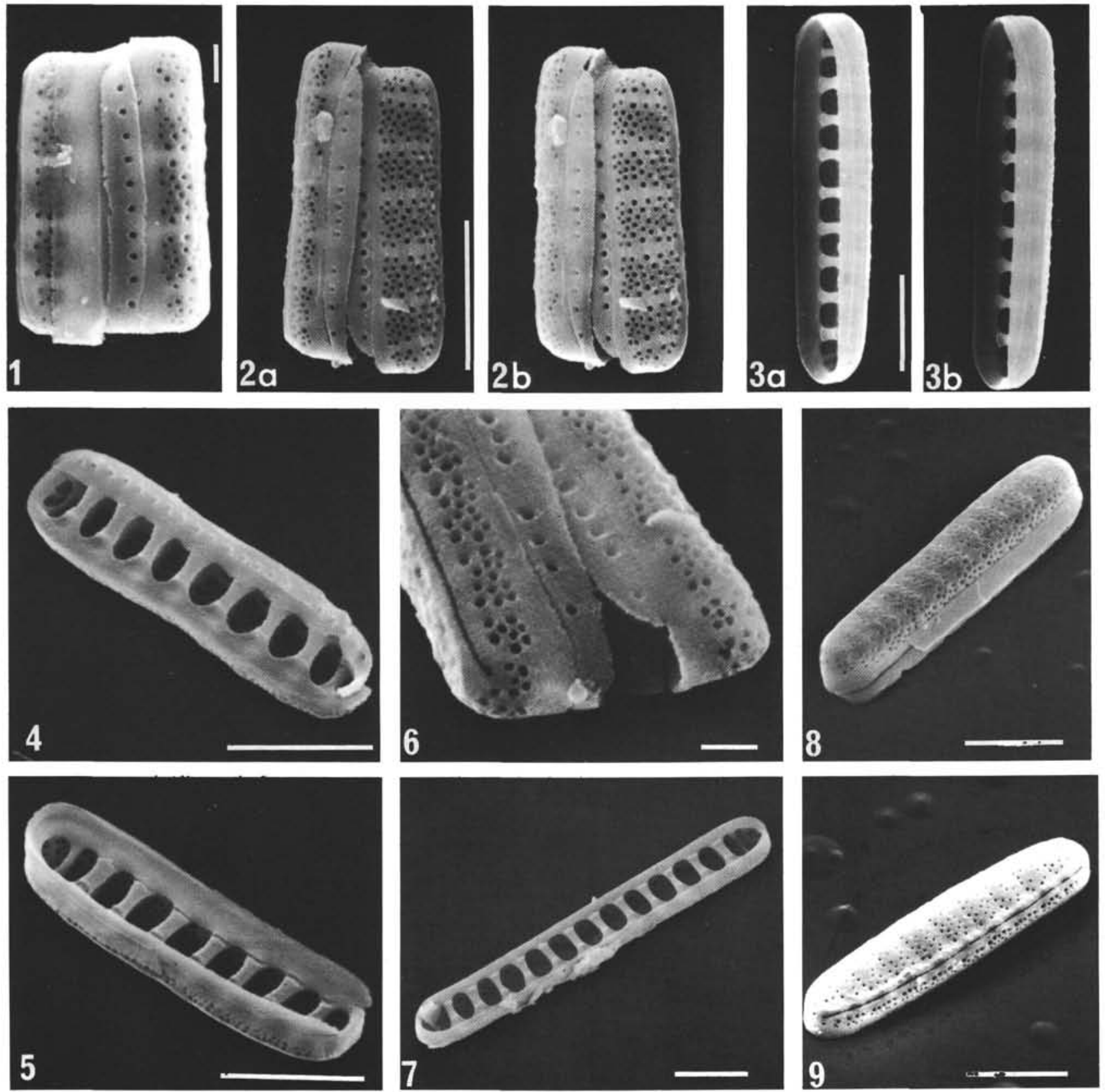

Plate 8. (Scale bar $=5 \mu \mathrm{m}$ unless otherwise indicated.) Denticulopsis praelauta Akiba and Koizumi, Sample JDS-10177, $\overline{\mathrm{Ot}} \mathrm{tsuka}$ Formation, Matsushima Area, northeastern Honshu. 1. Girdle view of frustule; epicopula is perforated by a row of puncta, whereas hypocopula is smooth, covered with pleurae of epitheca $(\mathrm{abr}=1 \mu \mathrm{m})$. 2A-B. Gridle views of frustule; both copulae are perforated by a row of puncta (stereoscopic pair). 3A-B. Oblique girdle views of hypovalve with smooth copula covered with pleurae of epitheca (stereoscopic pair). 4-5. The two thecae shown in Figures 4-5 had formed a frustule before sampling, (4) epivalve with punctated copula, one side of which is missing, (5) hypovalve with smooth copula covered with broken pleurae of epitheca. 6. Enlarged view of specimen in Figures $2 \mathrm{~A}-\mathrm{B}$ (bar $=1 \mu \mathrm{m}$ ). 7 . Valve interior showing portulae between pseudosepta. 8. Valve exterior with copula covered with broken pleurae of epitheca. 9. Valve exterior; raphe slit is divided. 

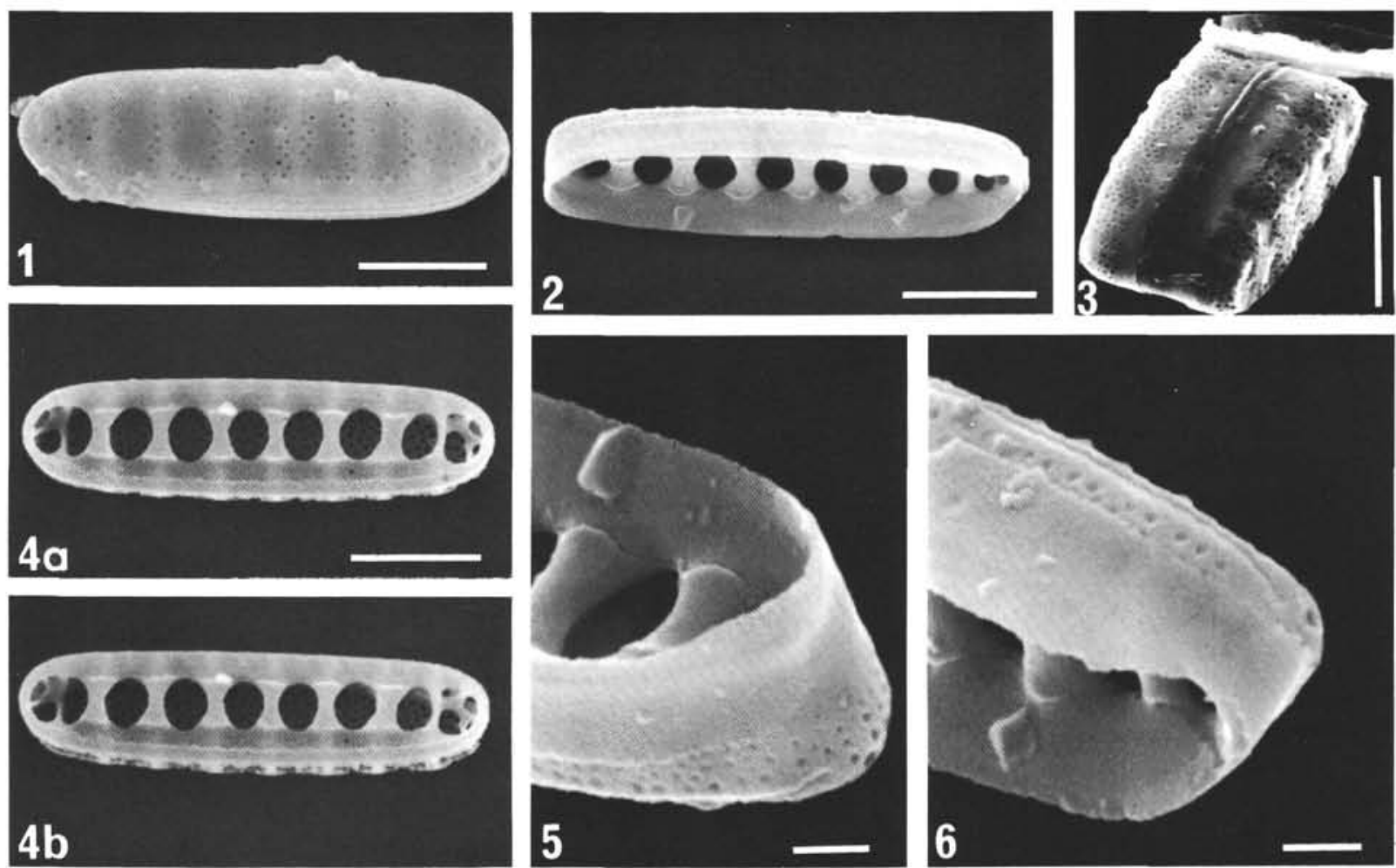

\section{$4 b$}
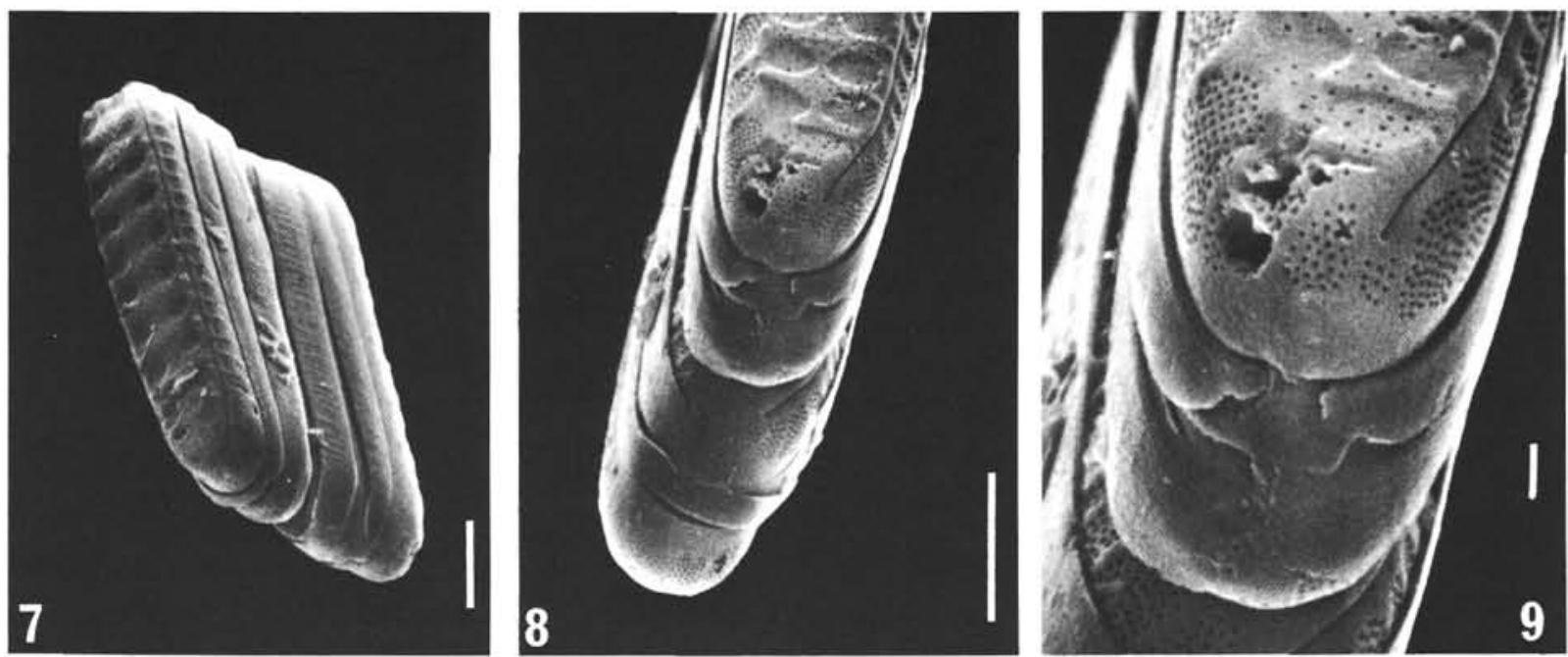

Plate 9. (Scale bar $=1 \mu \mathrm{m}$ unless otherwise indicated.) Denticulopsis lauta (Bailey) Simonsen, Sample JDS-10199, $\bar{O} t s u k a$ Formation, Matsushima Area, northeastern Honshu. 1. Valve exterior. 2. Internal view of hypovalve with smooth copula covered with pleura of epitheca. 3. Frustule with punctated epicopula. 4A-B. Valve interior; note apical pseudosepta (stereoscopic pair). 5-6. Enlarged views of specimen shown in Figure $2(\mathrm{bar}=1 \mu \mathrm{m}),(5)$ an apical portion where copula is closed, (6) the other apical portion where copula is open. 7. A part of chain by contact of valve face; raphe slit is divided into two branches. 8. Apical part of specimen shown in Figure 7; note sparser areolae on valve face than on mantle. 9. Enlarged view of Figure $8(\mathrm{bar}=1 \mu \mathrm{m})$. 

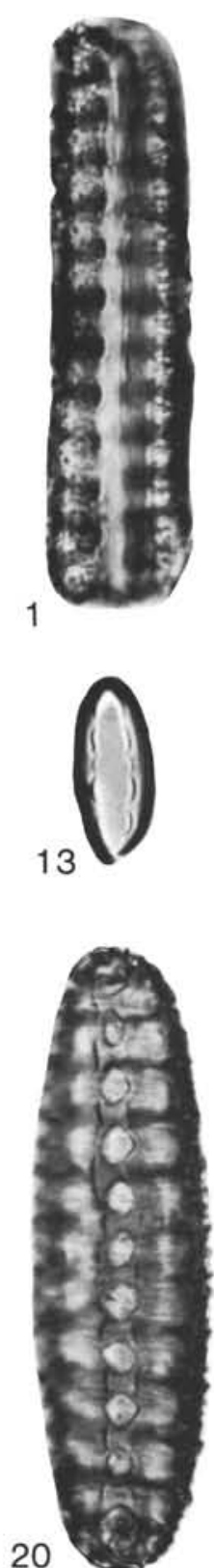
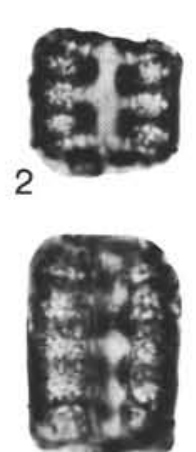

3
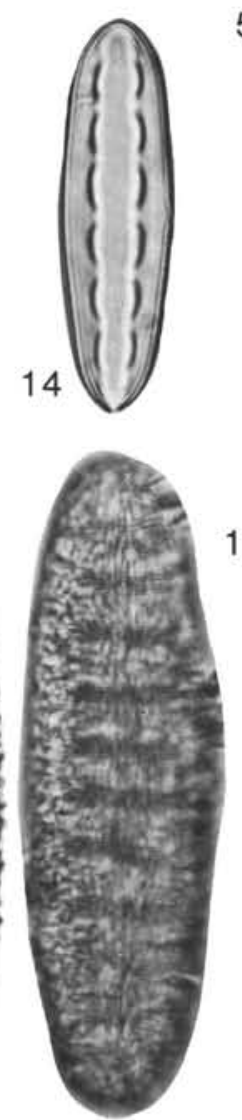
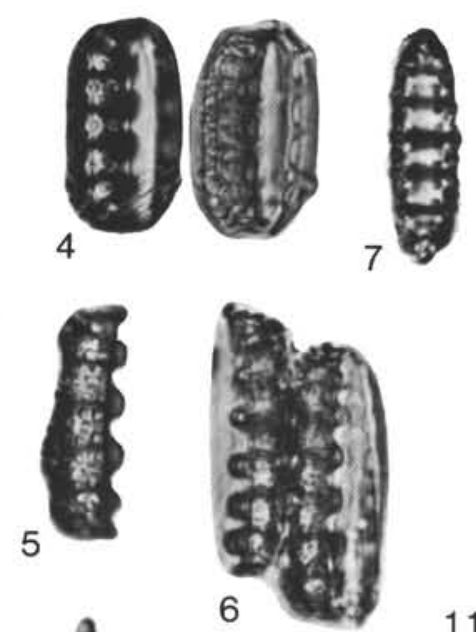

11
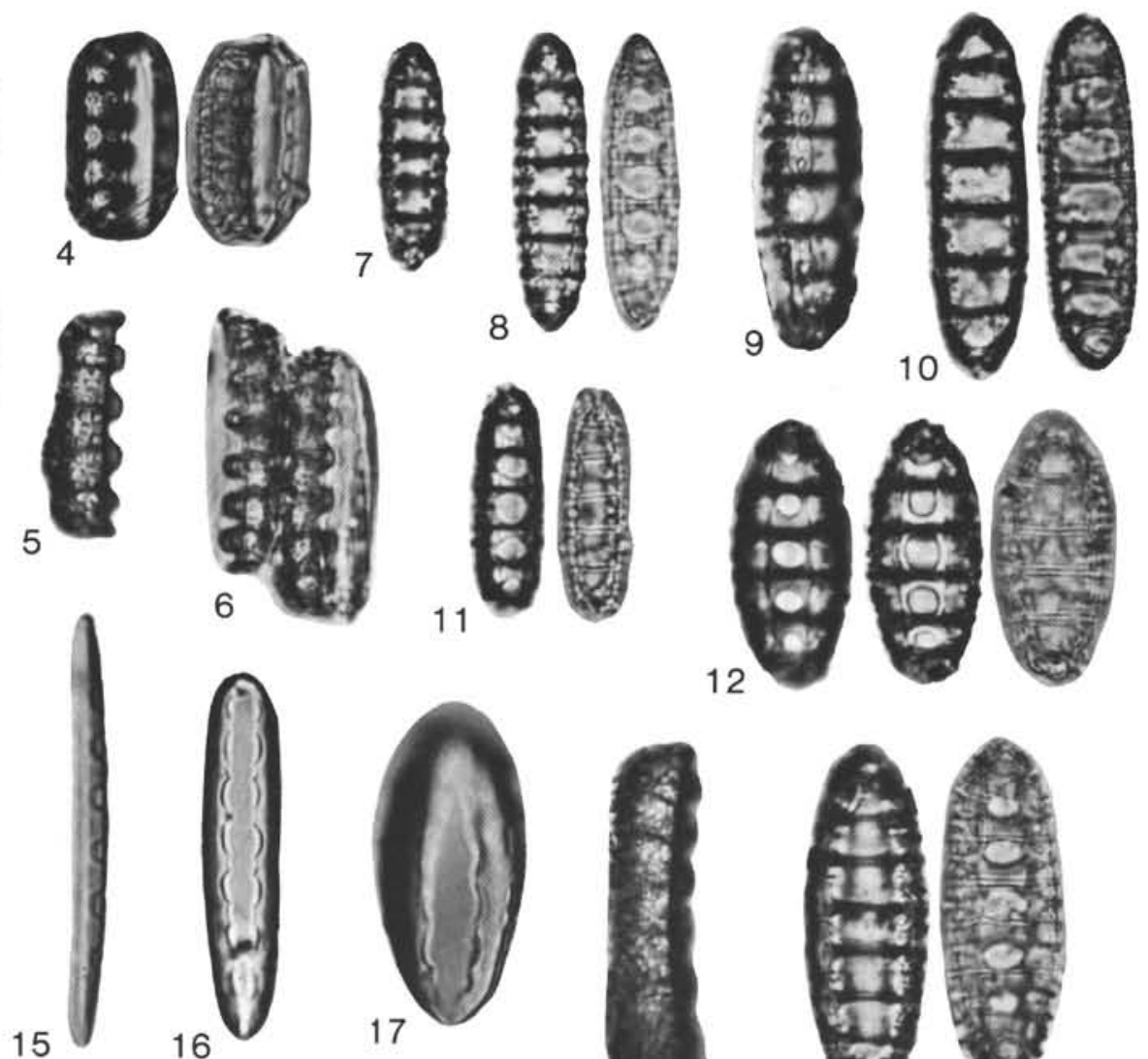

S
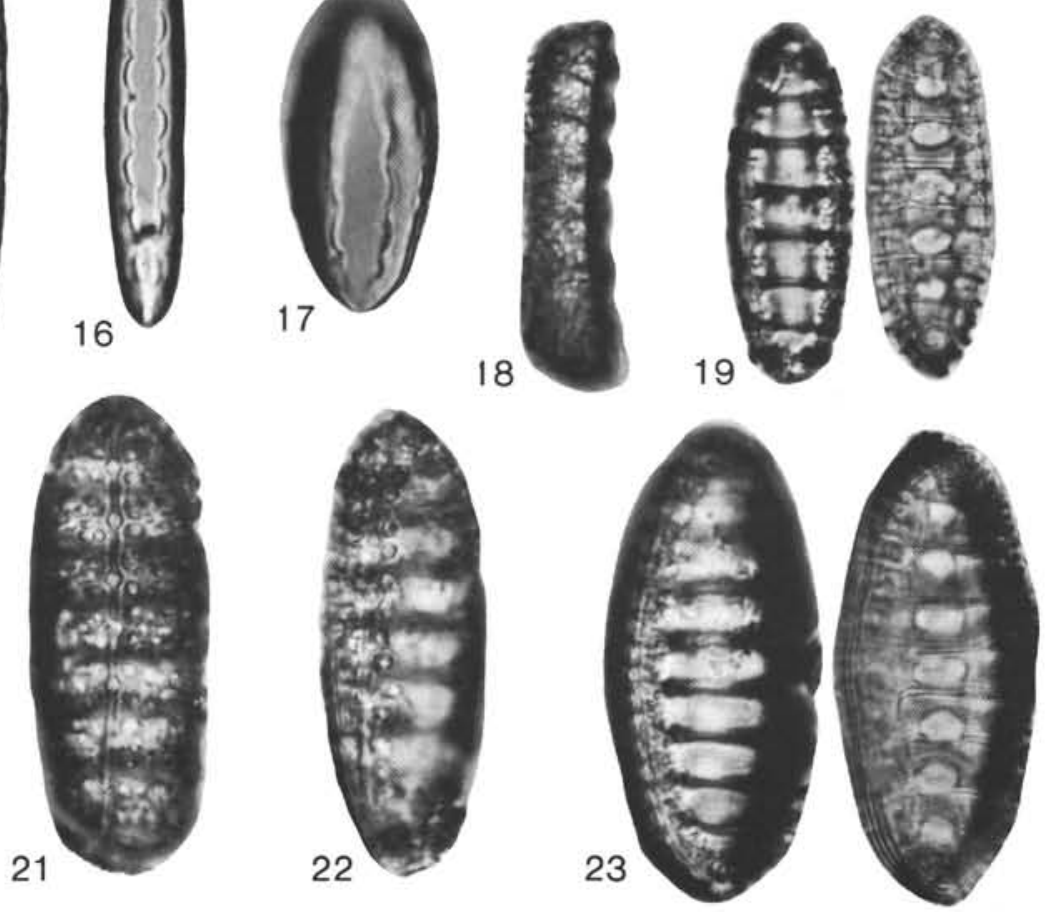

Plate 10. (All specimens magnified $\times 1500$.) Sample JDS-5801, an exotic block in Chokubetsu Formation, Atsunai Area, eastern Hokkaido. 1-16. Denticulopsis hyalina (Schrader) Simonsen, (1-3) girdle view of a frustule, (4) girdle view of a theca, (5) girdle view of a valve, (6) girdle view of part of colony, (12) inner valve view, (13-16) isolated copulae. 17-23. Denticulopsis miocaenica (Schrader) Simonsen, (17) isolated copula, (18) girdle view of a valve, (20-21) "Katahiraia"-type valve. 

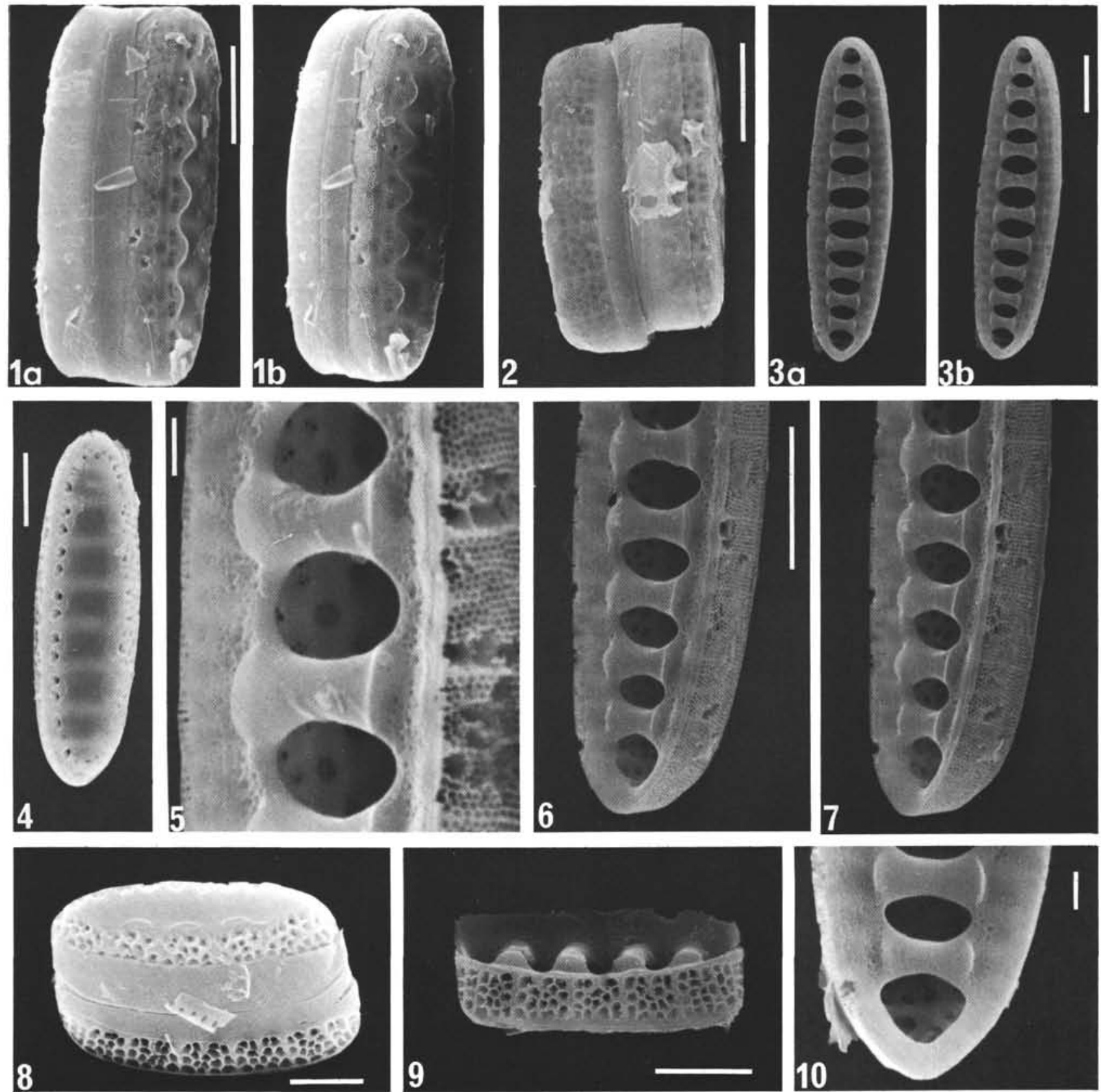

Plate 11. (Scale bar $=5 \mu \mathrm{m}$ unless otherwise indicated.) Denticulopsis hyalina (Schrader) Simonsen. 1-7, 9-10. Sample Tm 14, Monterey Formation, Newport Beach Section, California, (1A-B) oblique girdle views of frustule (stereoscopic pair), (2) girdle view of frustule, (3A-B) internal view of valve (stereoscopic pair), (4) external view of valve, (5) enlarged view of specimen shown in Figures 6-7 (bar $=1 \mu \mathrm{m})$, (6-7) internal views of valve (stereoscopic pair), (9) girdle view of valve with a half of copula, (10) apical part of valve interior (bar $=1 \mu \mathrm{m})$. 8. Sample JDS-5801, an exotic block in Chokubetsu Formation, Atsunai Area, eastern Hokkaido, frustule of which the outer finely punctated wall is dissolved. 

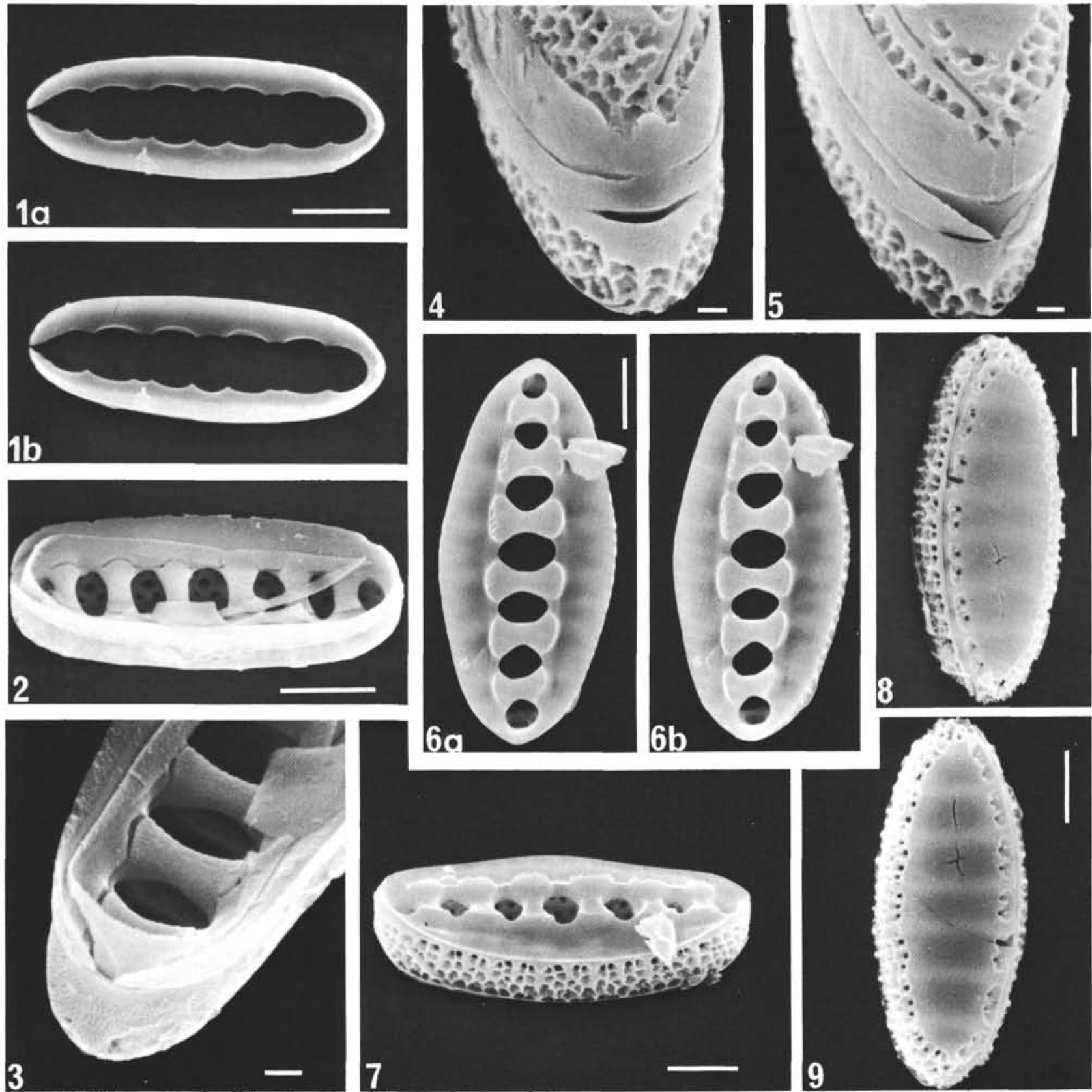

60

$6 \mathrm{~b}$

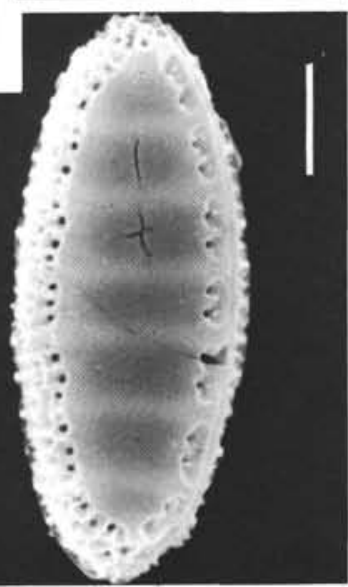

Plate 12. (Scale bar $=5 \mu \mathrm{m}$ unless otherwise indicated.) 1-5. Denticulopsis hyalina (Schrader) Simonsen, (1-3) Sample Tm 14, Monterey Formation, Newport Beach Section, California (1A-B, copula, stereoscopic pair; 2, valve with copula and first pleura; 3, enlarged view of an apical portion of specimen shown in Figure 2, bar $=1 \mu \mathrm{m}),(4-5)$ Sample JDS-5801, an exotic block in Chokubetsu Formation, Atsunai Area, eastern Hokkaido, enlarged views of apical portion of specimen shown in Plate 11, Figure 8 (bar $=1 \mu \mathrm{m}$ ). 6-9. Denticulopsis miocaenica (Schrader) Simonsen, Sample JDS-5801, an exotic block in Chokubetsu Formation, Atsunai Area, eastern Hokkaido, (6A-B) internal views of the valve (stereoscopic pair), (7) oblique girdle view of valve, (8) oblique external view of valve, (9) external view of valve (bar $=1 \mu \mathrm{m})$. 

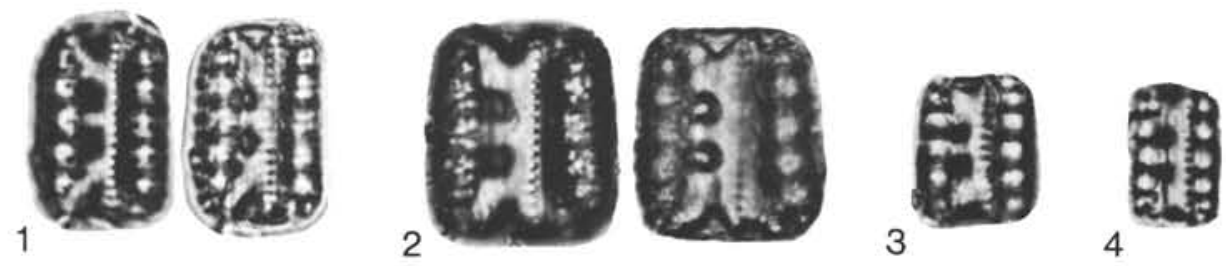

4
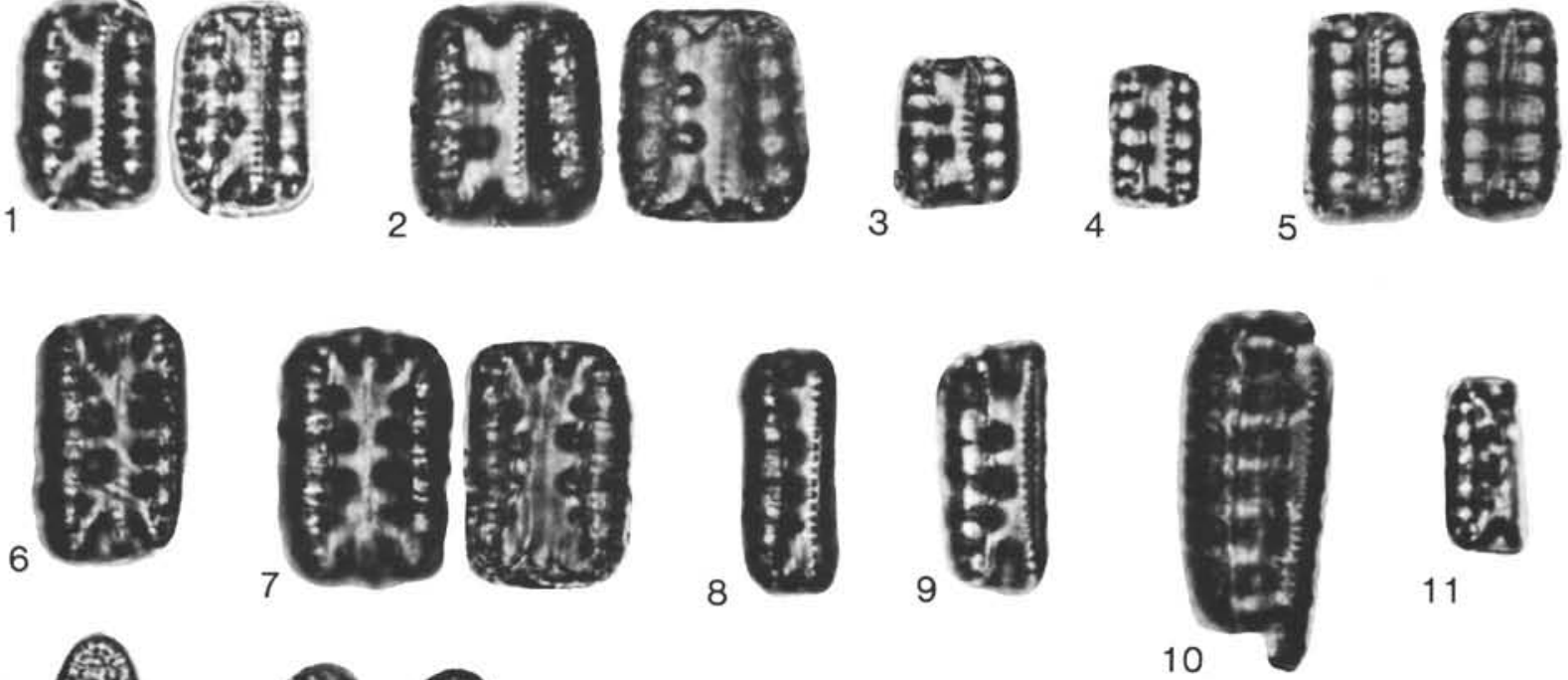

11
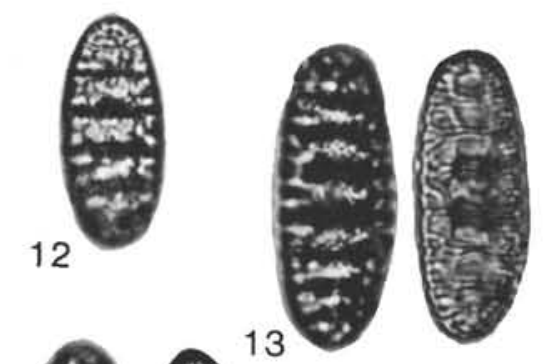

14
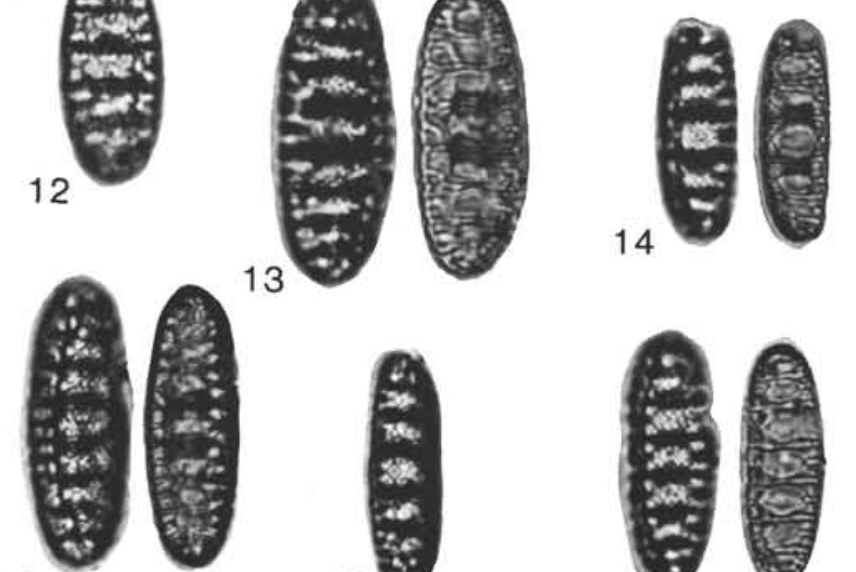

18
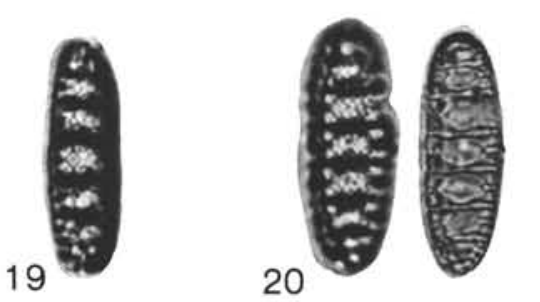

15

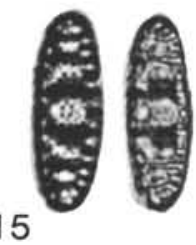

16
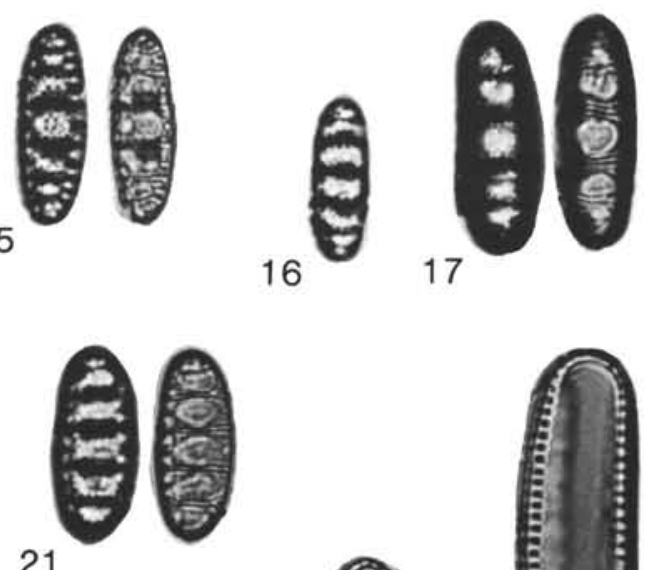

21
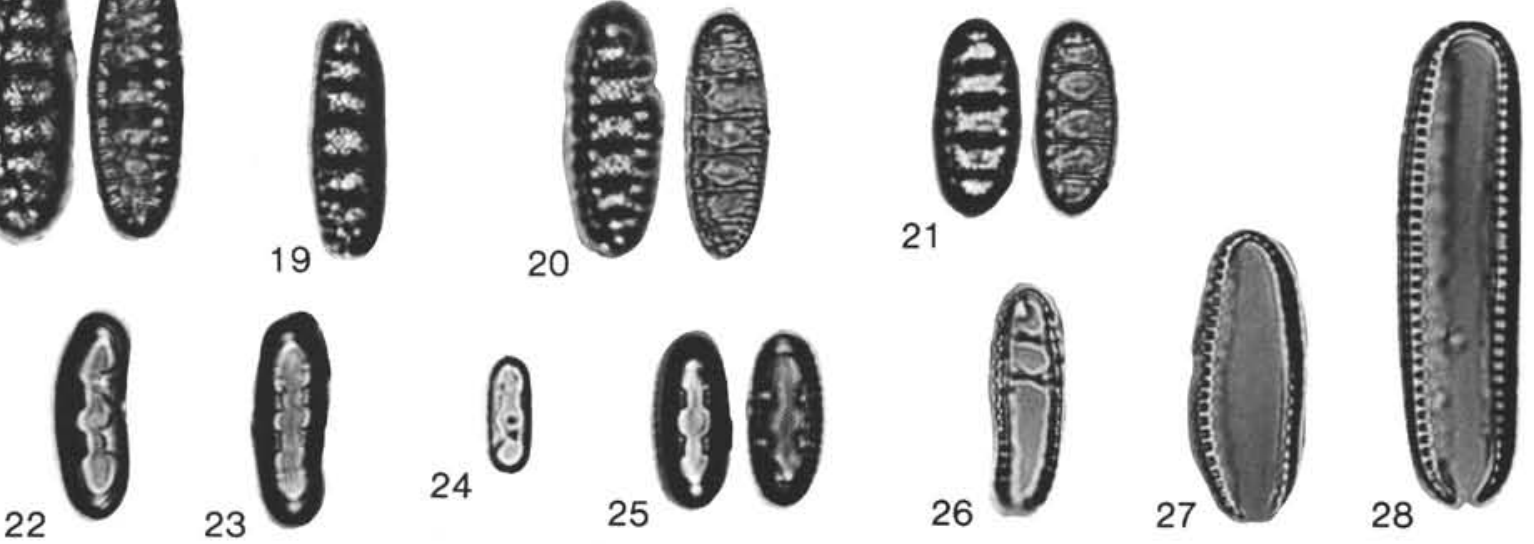

Plate 13. (All specimens magnified $\times 1500$.) Denticulopsis praedimorpha Barron ex Akiba. 1, 3-4, 9, 11-12. Sample 438A-64-7, 34-35 cm, (1, 3-4) heterovalvate frustule, $(9,11)$ broken frustule or theca, $(12)$ valve with well-developed crossbars in central part). 2. Sample 584-47, CC (reworked specimen?), heterovalvate frustule. 5. Sample 584-86,CC, isovalvate frustule. 6-8, 10, 13-15, 17-23, 25-28. Sample JDS-3663, Yuni Formation, Umaoiyama Area, central Hokkaido, $(6)$ isovalvate frustule, $(8,10)$ broken frustule or theca, $(17)$ theca in valve view, valve with welldeveloped crossbars and closed copula, $(22,23,25)$ isolated closed copula, $(26,28)$ isolated open copula with a row of puncta. 16,24 . Sample 438A-66-2, 34-36 cm, (24) isolated closed copula. 

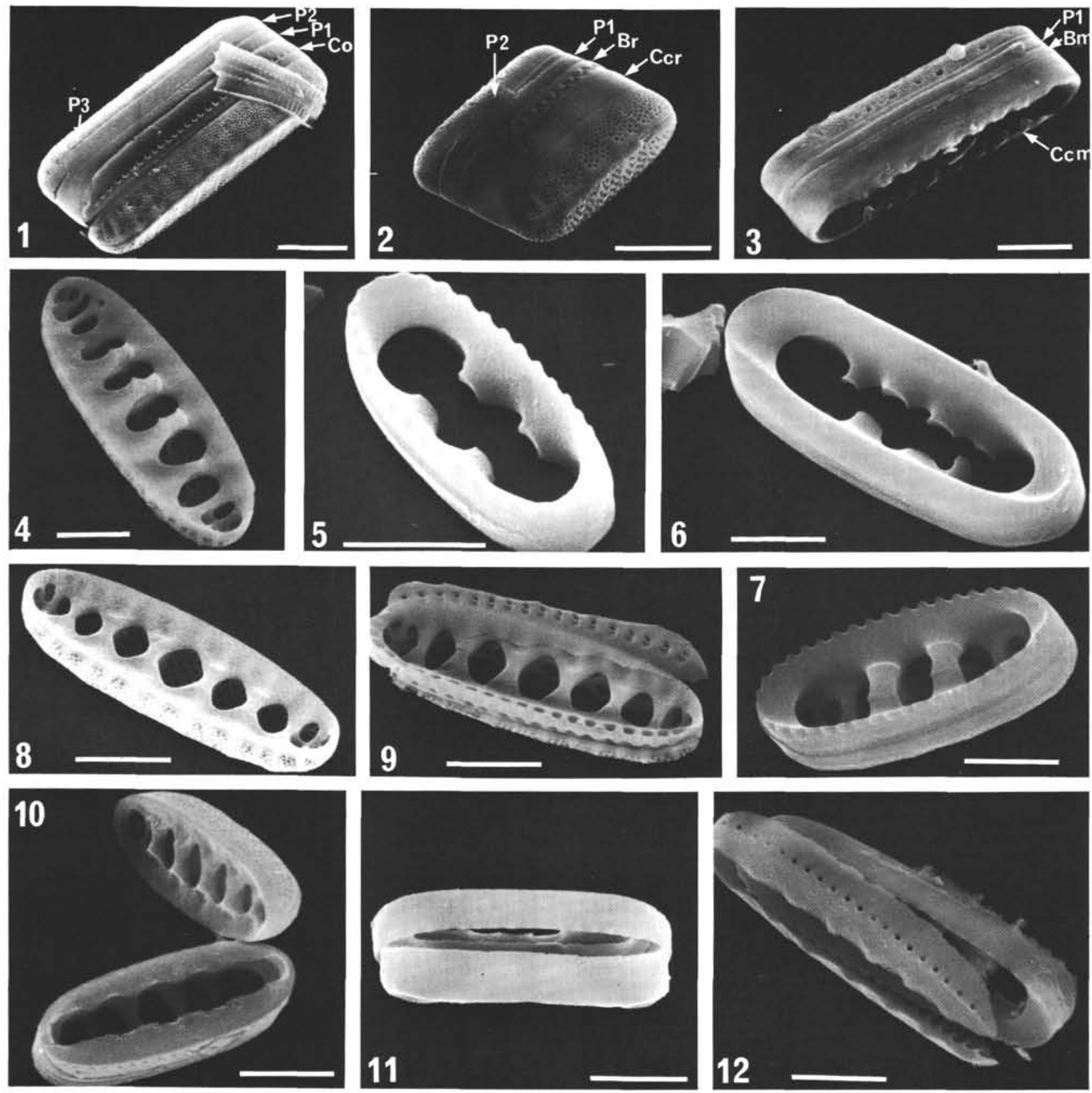

Plate 14. (Scale bar $=5 \mu \mathrm{m}$.) Denticulopsis praedimorpha Barron ex Akiba, Sample JDS-8865, Masuura Formation, Abashiri Area, eastern Hokkaido. 1. Frustule with punctate open epicopula (Co), three epipleurae (P1-P3) and closed hypocopula. 2. Frustule with serrate closed epicopula (Ccr), special band (Br), two epipleurae (P1-P2), and closed hypocopula. 3. Frustule without epivalve, with smooth closed epicopula $(\mathrm{Ccm})$, special band $(\mathrm{Bm})$, one epipleura (P1), and closed hypocopula. 4. Internal view of valve with high and short crossbars. 5. Closed copula with serrate margin $(\mathrm{Ccr})$. 6. Closed copula with smooth margin $(\mathrm{Ccm})$. 7. Valve with high crossbars, combined with serrate closed copula. 8. Internal view of valve with low and indistinct crossbars. 9. Valve with low crossbars, combined with punctated open copula (Cco). 10. Separated frustule. 11. Combination of two smooth closed copulae $(\mathrm{Ccm} / \mathrm{Ccm})$. 12. Combination of open copula and serrate closed copula $(\mathrm{Co} / \mathrm{Ccr})$. 


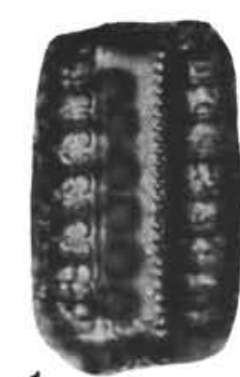

1

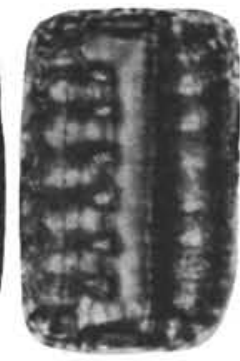

2
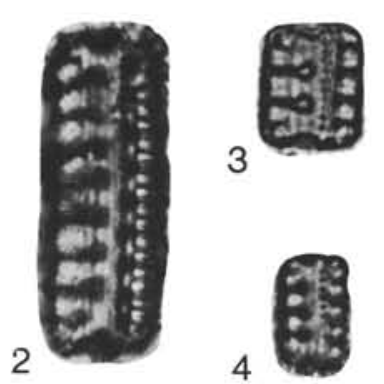

4
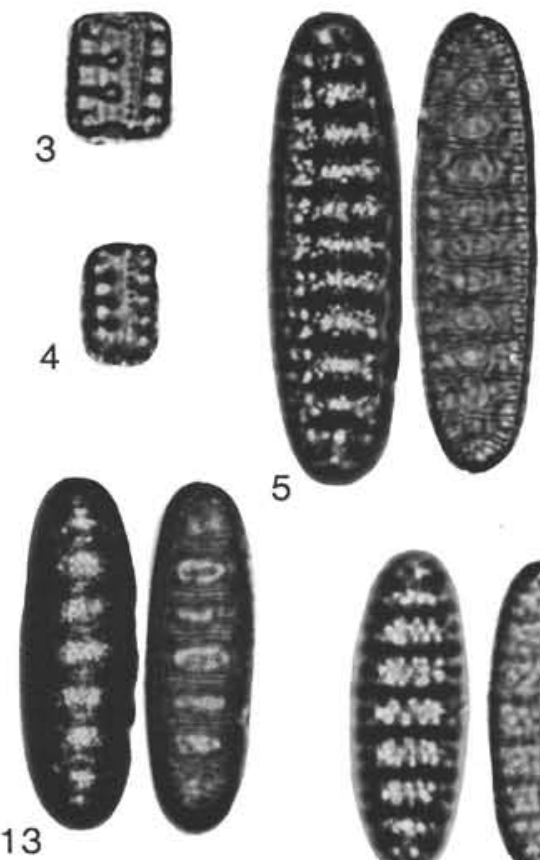

5
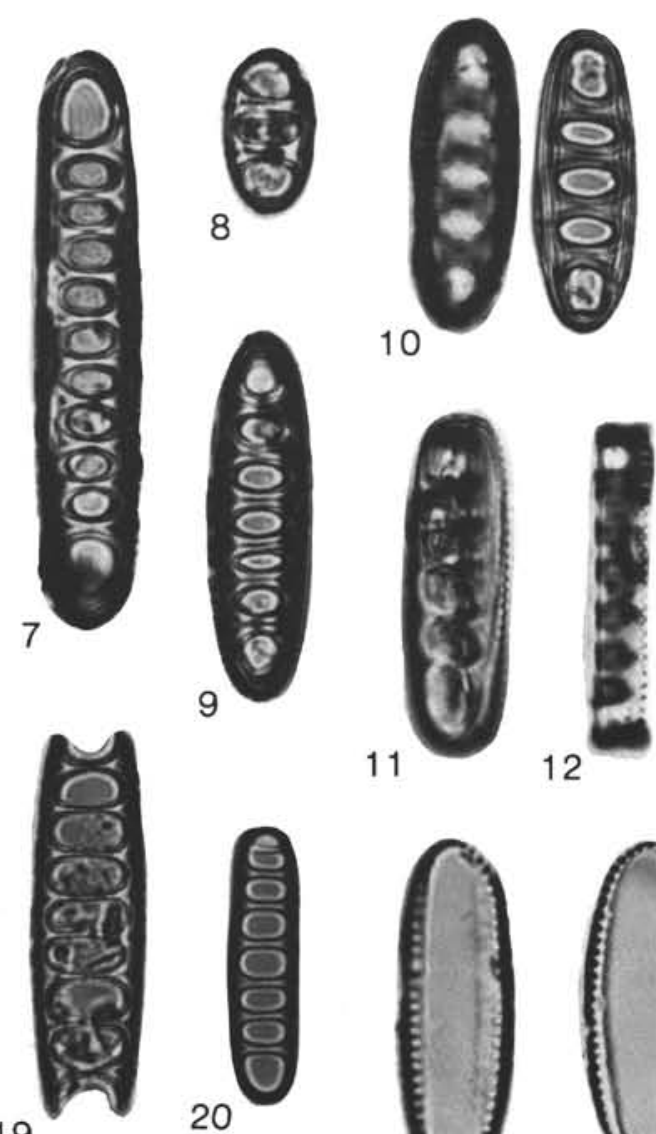

19

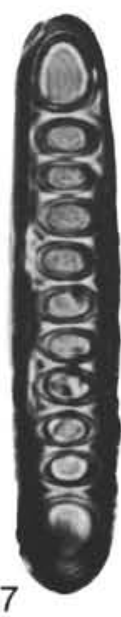

8
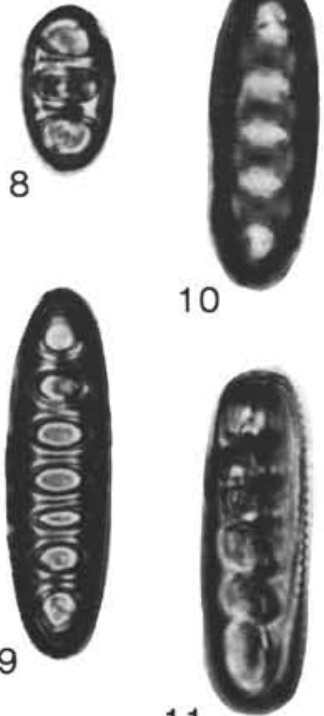

11

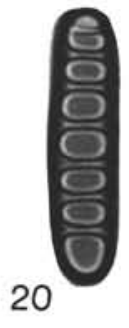

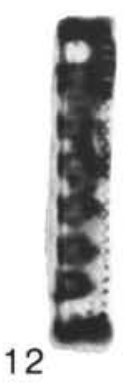

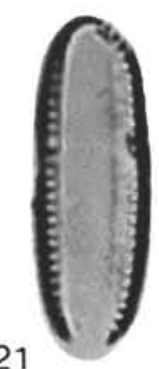

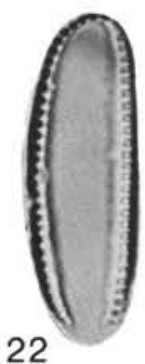
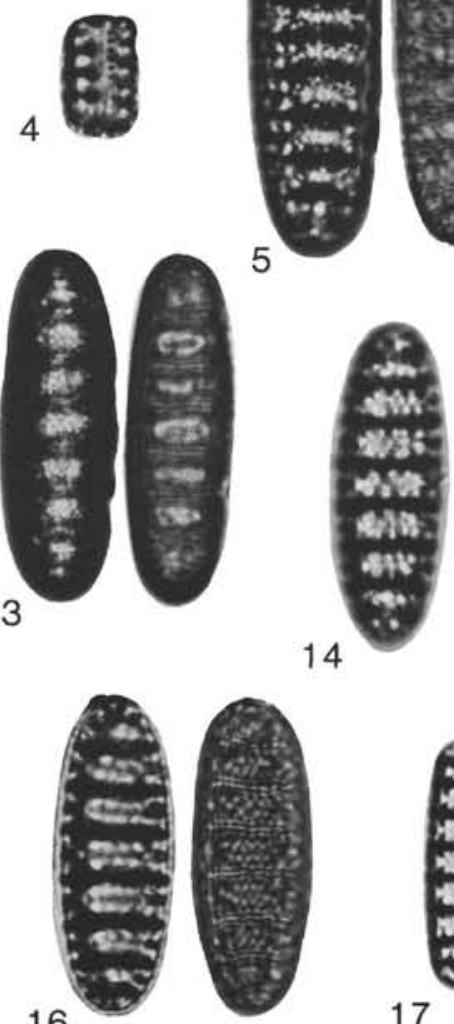

17

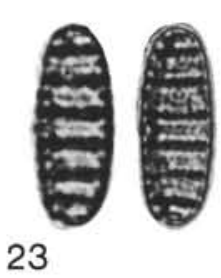

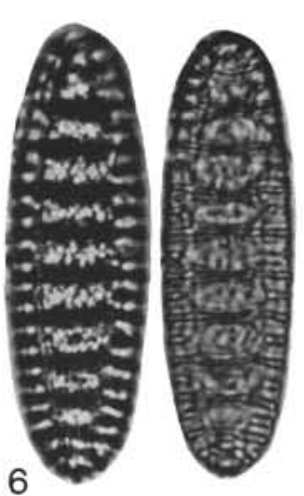
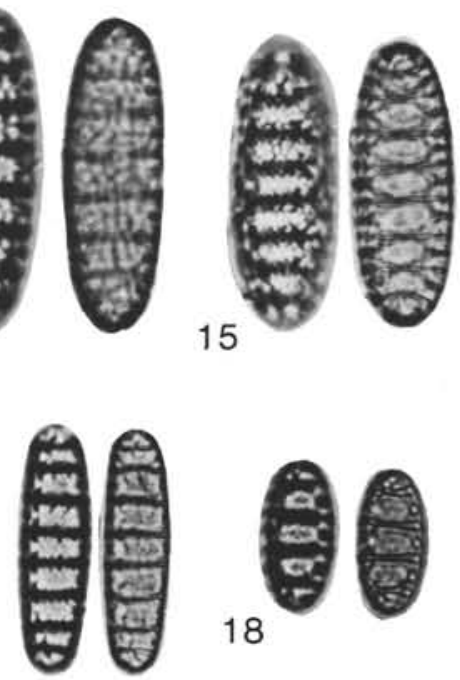

18
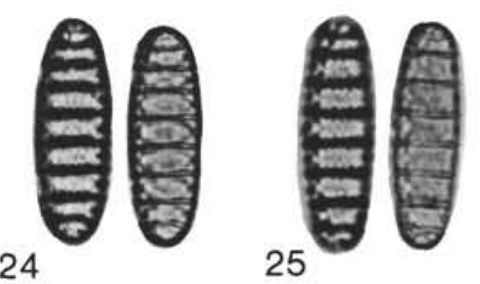

Plate 15. (All specimens magnified $\times 1500$.) Denticulopsis dimorpha (Schrader) Simonsen. 1-4, 11, 23. Sample 438A-56,CC (1-4) frustule, (23) valve with striae or normal puncta). 5-10, 13, 16, 18-22. Sample 183-19-2, 80-82 cm, $(5-6,16)$ valve with areoliert-puncta, (7-10, 19-20) isolated closed copulae, (13) theca in valve view, valve with areoliert-puncta and closed band, (18) valve with striae, (21-22) isolated open copulae with a row of puncta),12, 14-15, 17, 24-25. Sample JDS-5743, Moebetsu Formation, Hayakita Area, central Hokkaido, (14-15) valve with areoliert-puncta, $(17,24-25)$ valve with striae. 

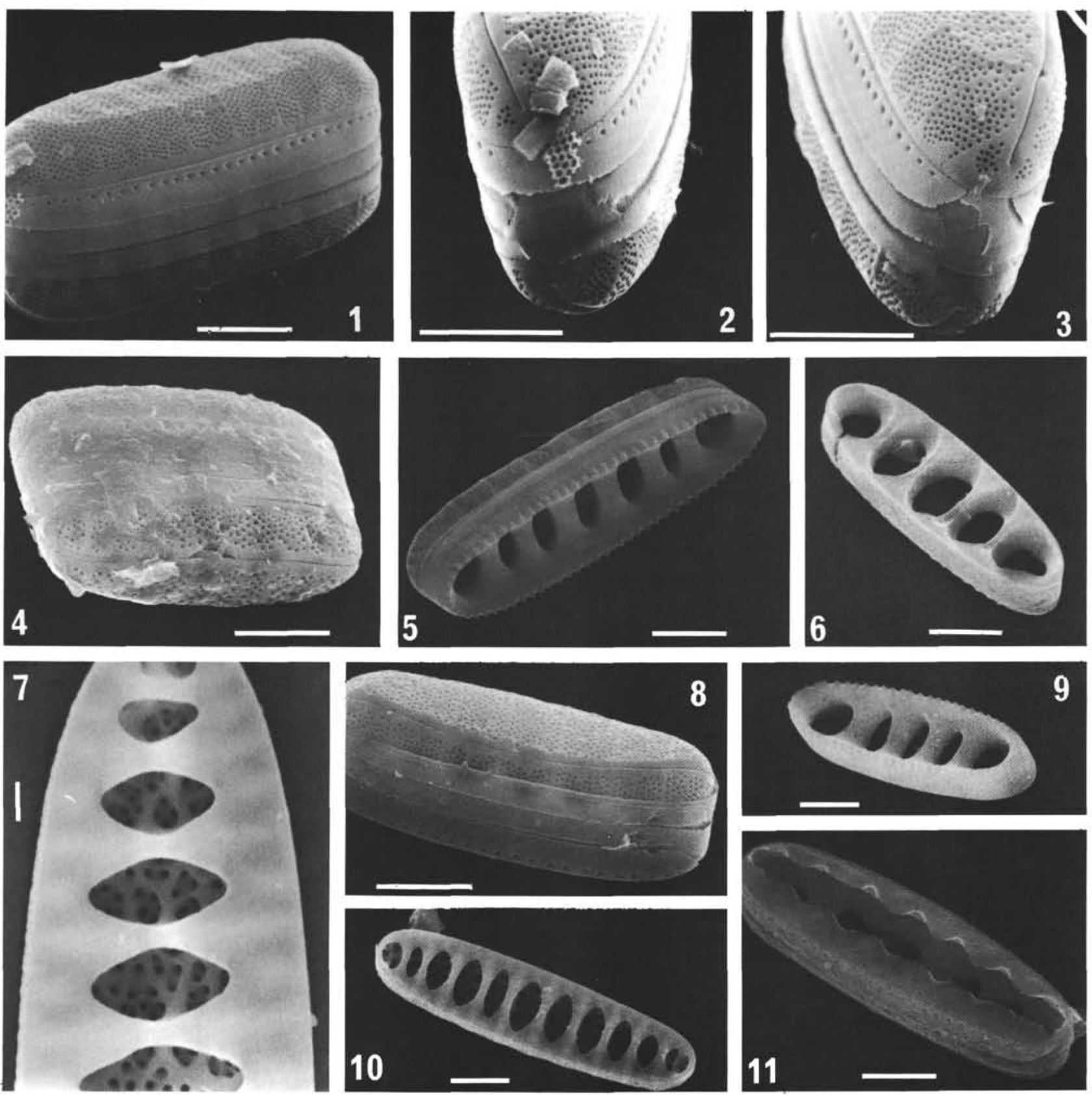

Plate 16. (Scale bar $=5 \mu \mathrm{m}$ unless otherwise indicated.) Denticulopsis dimorpha (Schrader) Simonsen, Sample JDS-5743, Moebetsu Formation, Hayakita Area, central Hokkaido. 1. Frustule with punctate open epicopula, two epipleurae, and closed hypocopula. 2. One apex of specimen shown in Figure 1. 3. The other apex of specimen shown in Figure 1. 4. Frustule in girdle view. 5. Hypovalve with serrate closed copula, covered with a epipleurae. 6. Advalvar surface of closed copula. 7. Valve interior with inner chamberlike large puncta (bar $=1 \mu \mathrm{m})$. 8 . Frustule without epivalve, with punctate open epicopula and three epipleurae; raphe slit is divided into two branches. 9. Closed copula with serrate margin. 10. Internal view of valve without crossbars. 11. Punctate open copula combined with closed copula. 

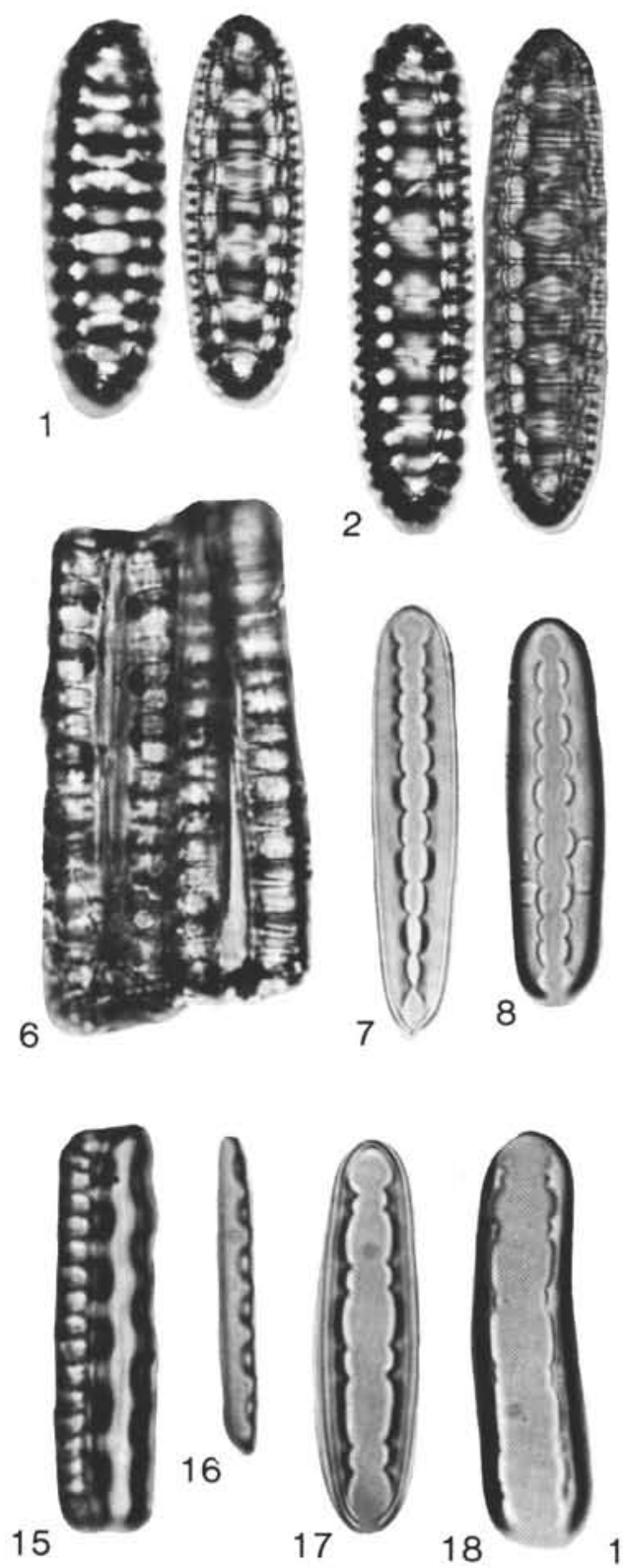

11
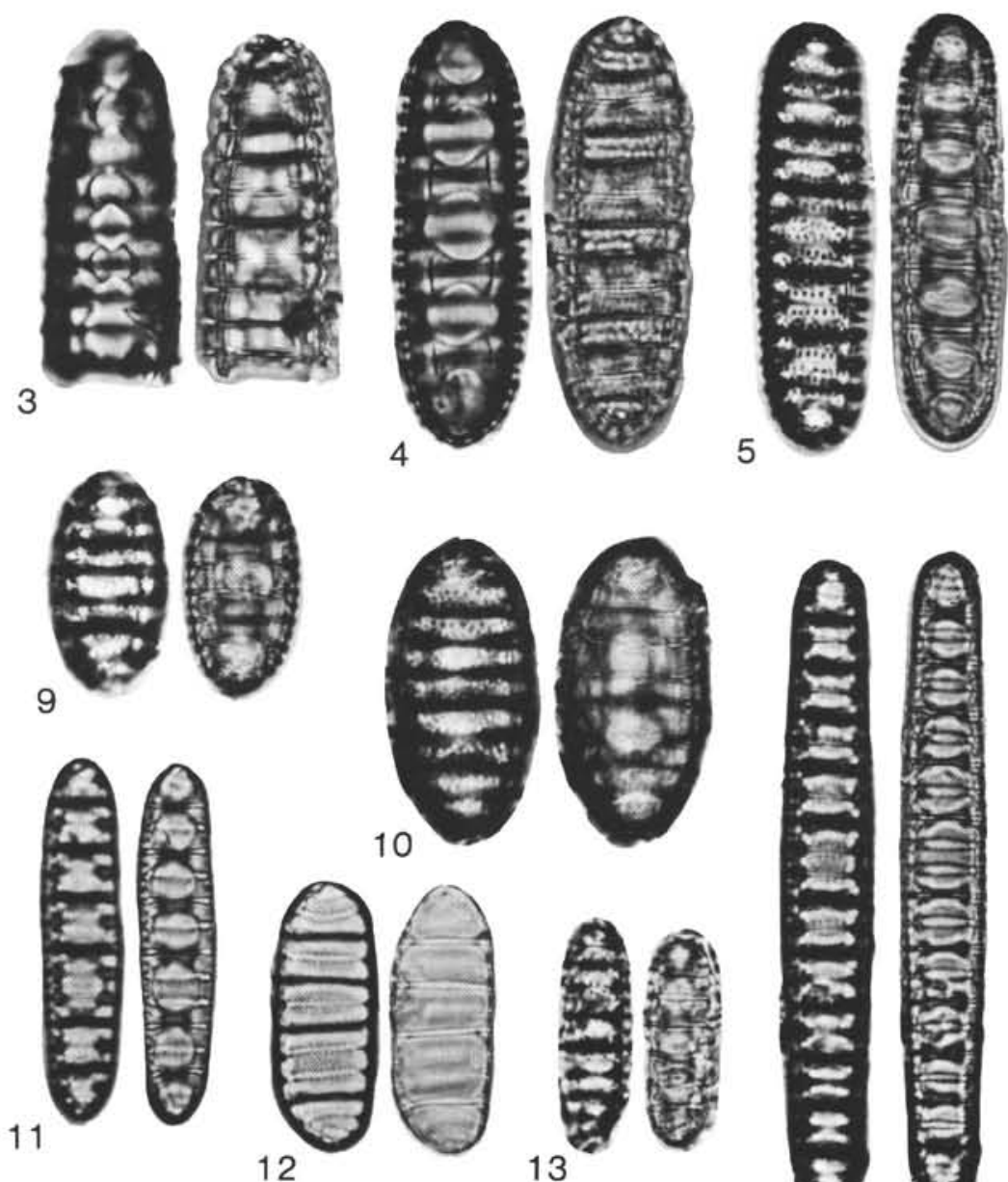

12
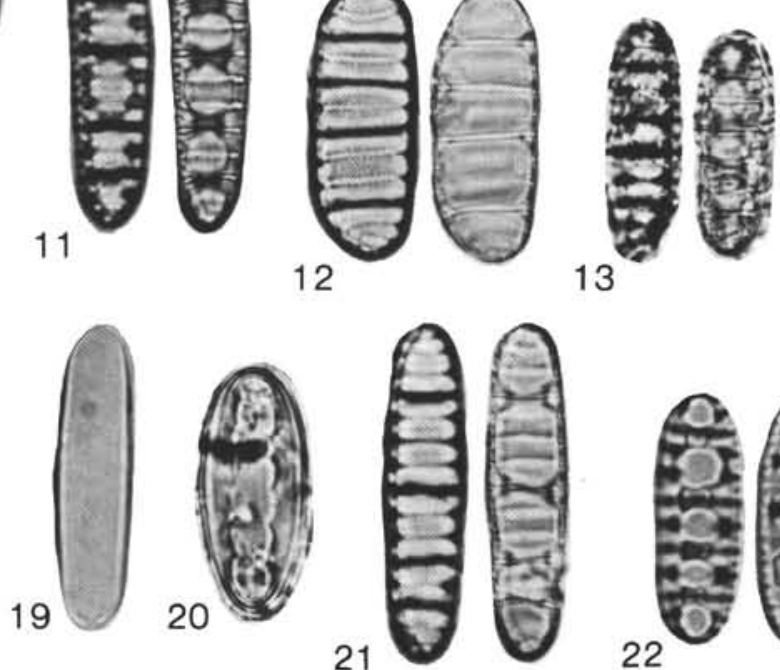

13

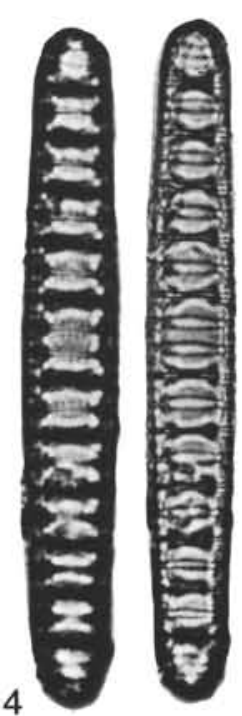

Plate 17. (All specimens magnified $\times 1500$.) 1-3, 6. Denticulopsis katayamae Maruyama, (1-3) Sample 192-25-1, 80-82 cm, (6) Sample 438A-53-2,

$30-31 \mathrm{~cm} . \quad 4,5,7-23$. Denticulopsis hustedtii (Simonsen and Kanaya) Simonsen, (4-5) Sample 192-24,CC, (7-8, 11-12, 15-19, 21-23) Sample

JDS-11452, Chokubetsu Formation, Atsunai Area, eastern Hokkaido, (9-10, 20) Sample 438A-65-7, 17-18 cm, (13) Sample 438A-66-2, 82-84 cm,

(14) Sample JDS-11921, Isozaki Formation. 

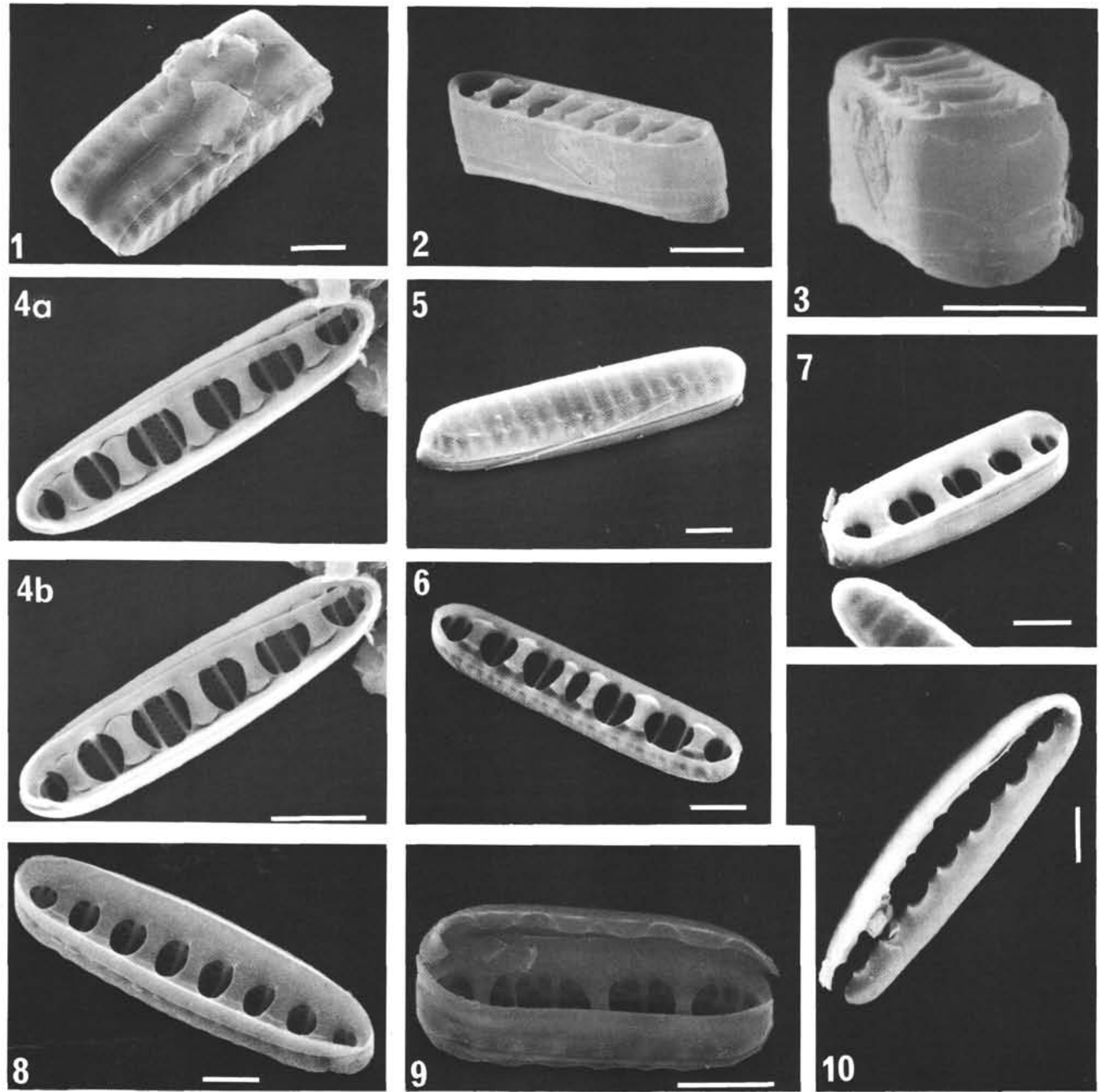

Plate 18. (Scale bar $=5 \mu \mathrm{m}$.) Denticulopsis hustedtii (Simonsen and Kanaya) Simonsen. 1-3, 5-7, 9. Sample JDS-10242, Hataya Formation, Matsushima Area, northeastern Honshu, (1) frustule in girdle view, (2-3) two valves combined by contact of valve face, (5) oblique view of valve exterior, (6) oblique view of valve interior, (7) oblique internal view of hypovalve with copula covered with epipleurae, (9) oblique internal view of hypovalve with copula covered with epipleurae, and with a half of an epicopula. 4A-B. Sample JDS-8864, Masuura Formation, Abashiri Area, eastern Hokkaido, internal view of valve with copula and one pleura (stereoscopic pair). 8, 10. Sample JDS-5743, "Moebetsu" Formation, Hayakita Area, central Hokkaido, (8) oblique internal view of valve with copula, (10) open copula. 

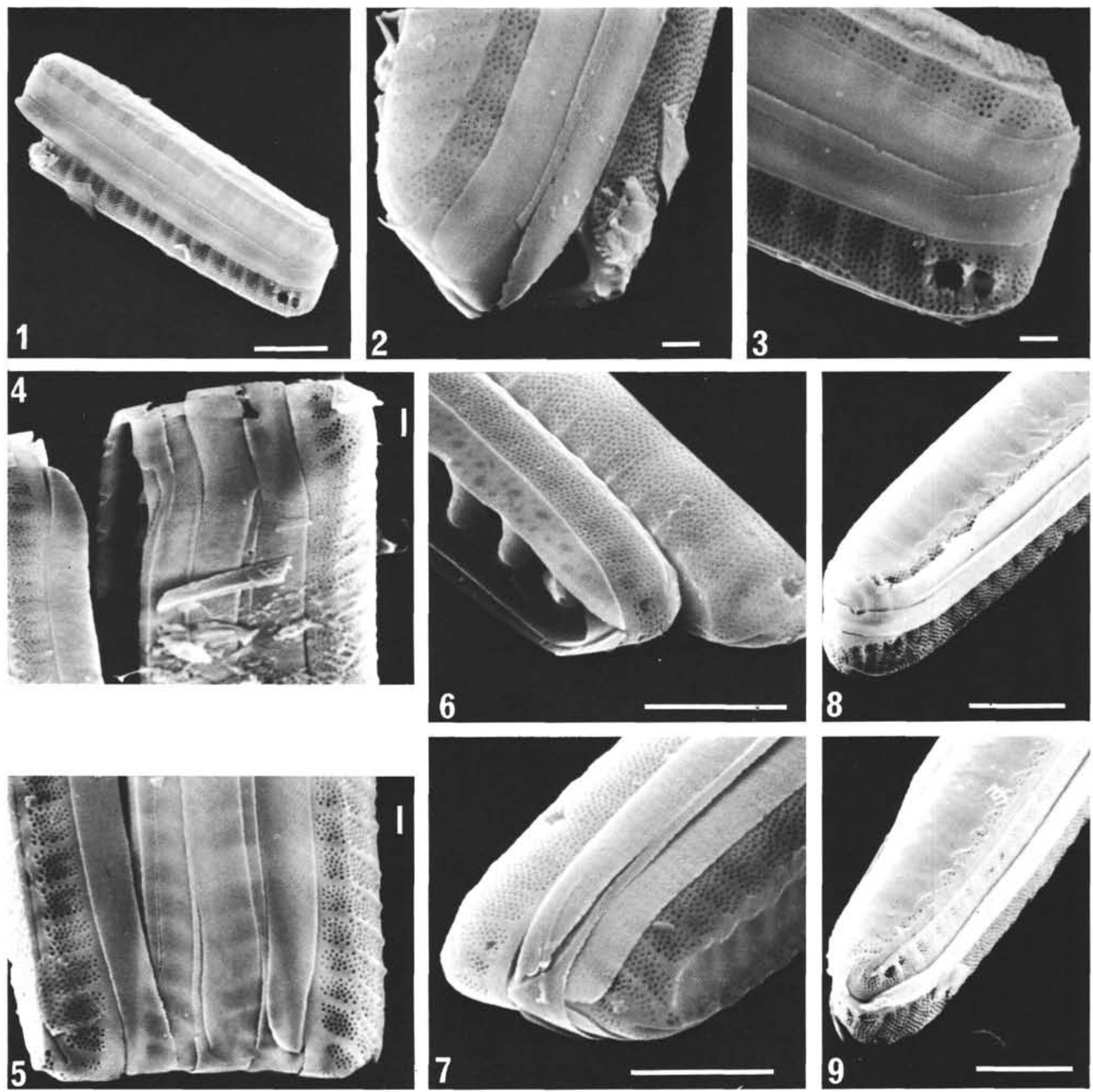

Plate 19. (Scale bar $=5 \mu \mathrm{m}$ unless otherwise indicated.) 1-5. Denticulopsis hustedtii (Simonsen and Kanaya) Simonsen, (1-3) Sample Kt 81-4, Tsuzuriko Formation, Takanosu Area, northern Honshu, frustule (1, oblique girdle view; 2 , an apical portion, bar $=1 \mu \mathrm{m} ; 3$, the other apical portion: note open copula, narrow first pleura, broad second pleura, and narrow third pleura, bar $=1 \mu \mathrm{m})$, (4-5) Sample JDS-11921, Isozaki Formation, Ajigaura Area, northeastern Honshu, girdle views of frustule presumed in the process of cell division (bar $=1 \mu \mathrm{m})$. 6-9. Denticulopsis katayamae Maruyama, Sample 438A-53-2, 30-31 cm, off Hachinohe, northwestern Pacific, (6) valves combined by contact of valve face, (7) apical part of frustule, note open copula, narrow first pleura and broad second pleura, $(8,9)$ frustule $(8$, an apical portion, note triangular thickly silicified hyaline area on rapheless margin of valve face between pseudosepta; 9 , the other apical portion, note triangular thickly silicified punctate area on raphe-bearing margin of valve face between pseudosepta; hypocopula is not recognized). 

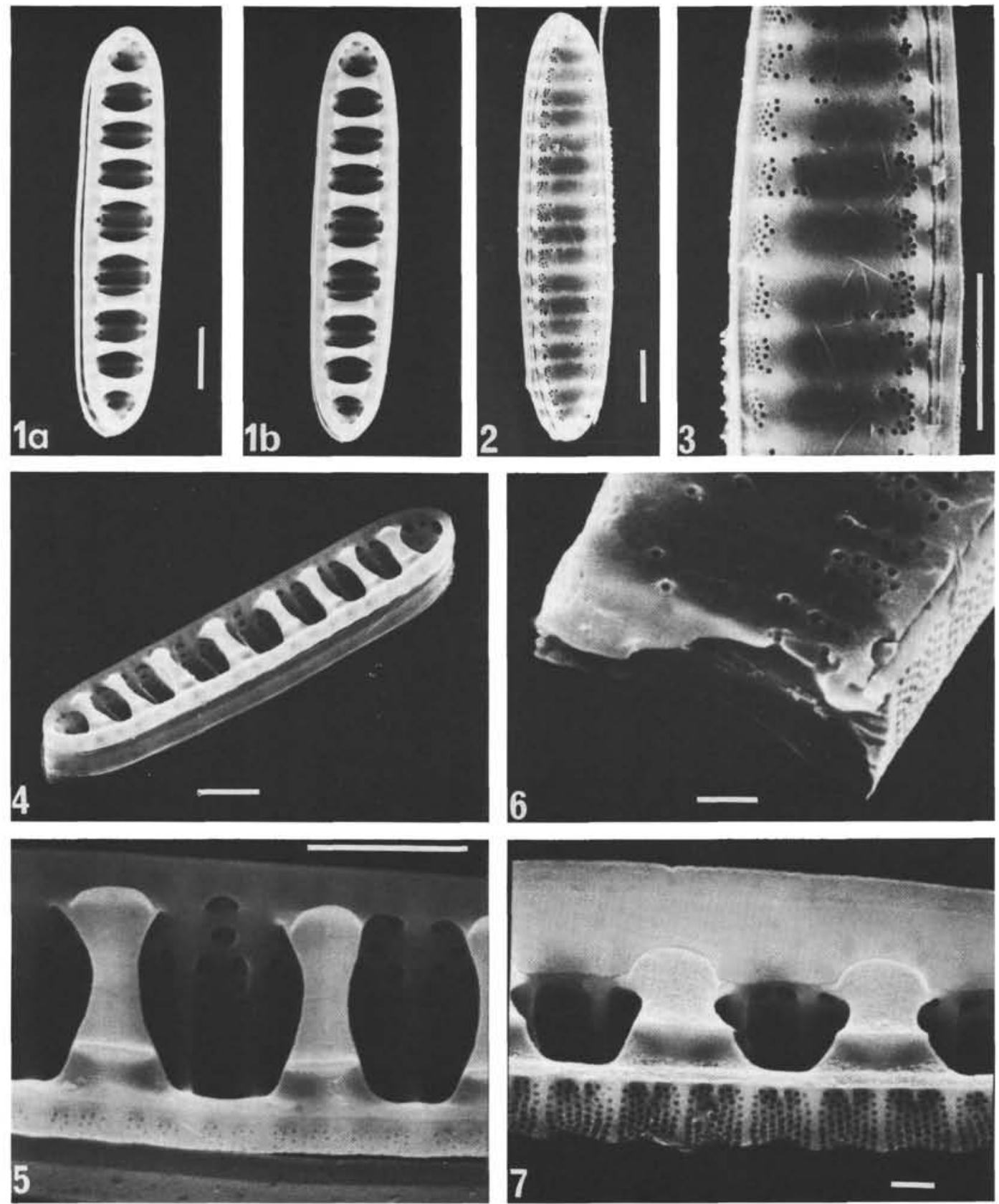

Plate 20. (Scale bar $=5 \mu \mathrm{m}$ unless otherwise indicated.) Denticulopsis katayamae Maruyama, Sample 438A-53-2, 30-31 cm, off Hachinohe, northwestern Pacific. 1A-B. Valve interior (stereoscopic pair). 2. Valve exterior. 3. Enlarged view of middle portion of specimen shown in Figure 2, valve face is hyaline, raphe slit is divided into two branches. 4. Oblique internal view of specimen shown in Figure 1A-B. 5. Enlarged view of specimen shown in Figure 4, note circular portula between each two pseudosepta. 6. A broken valve, note circular raphe canal in cross section $(\mathrm{bar}=1 \mu \mathrm{m})$. 7. Middle portion of valve with a half of copula (bar $=1 \mu \mathrm{m})$. 

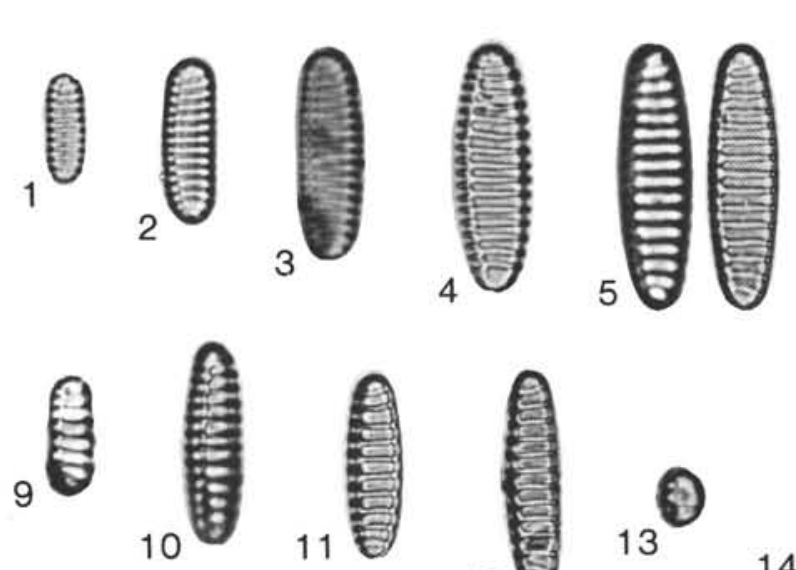

11
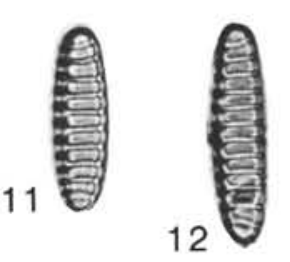

6
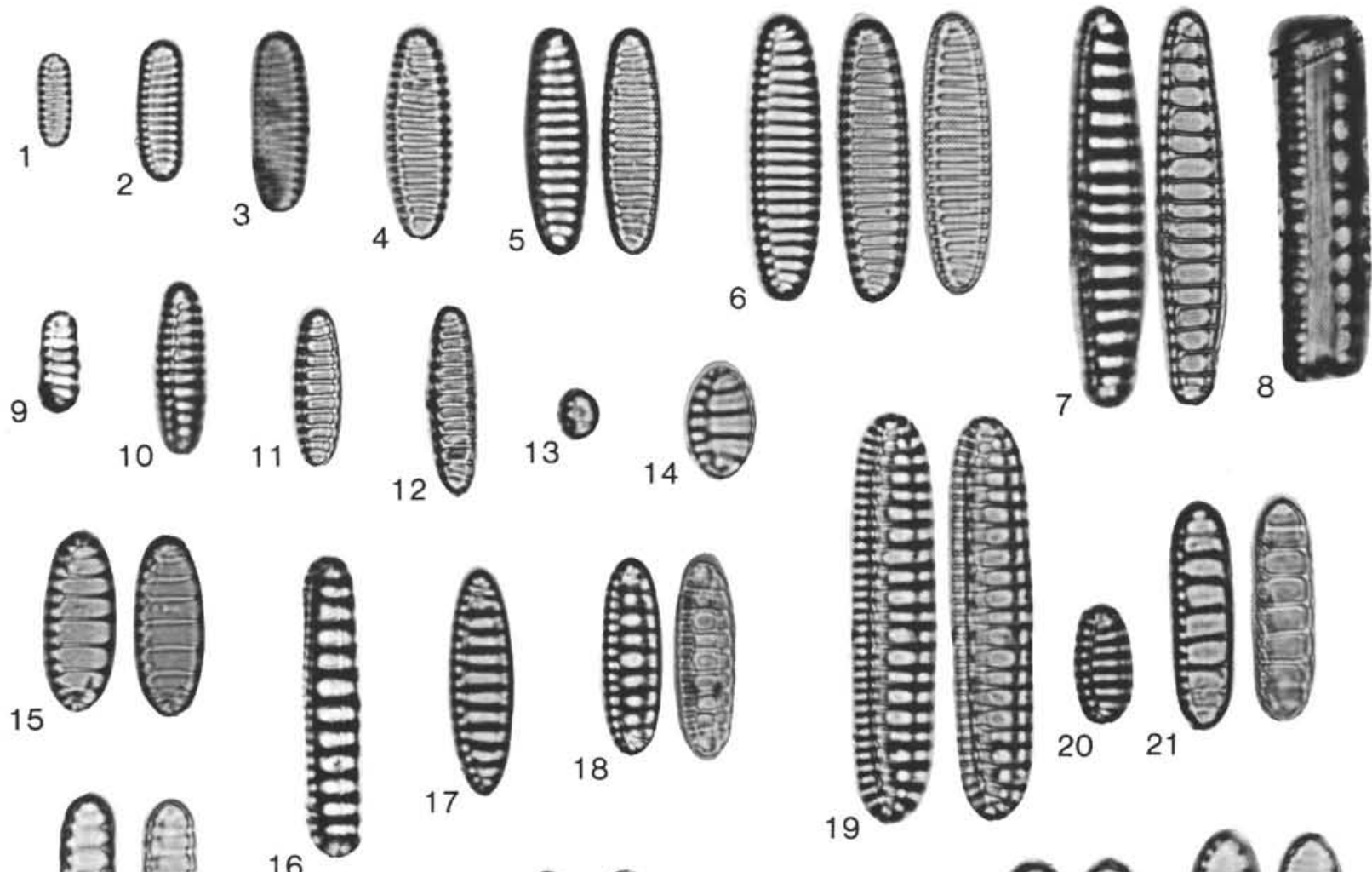

13
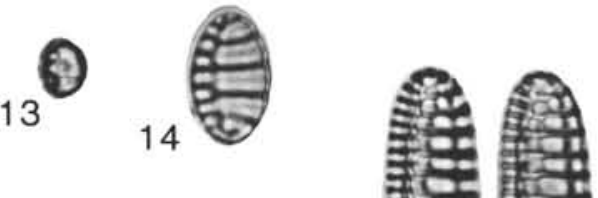

8

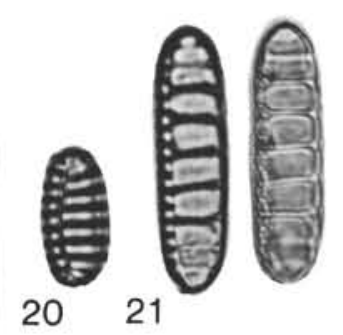

19
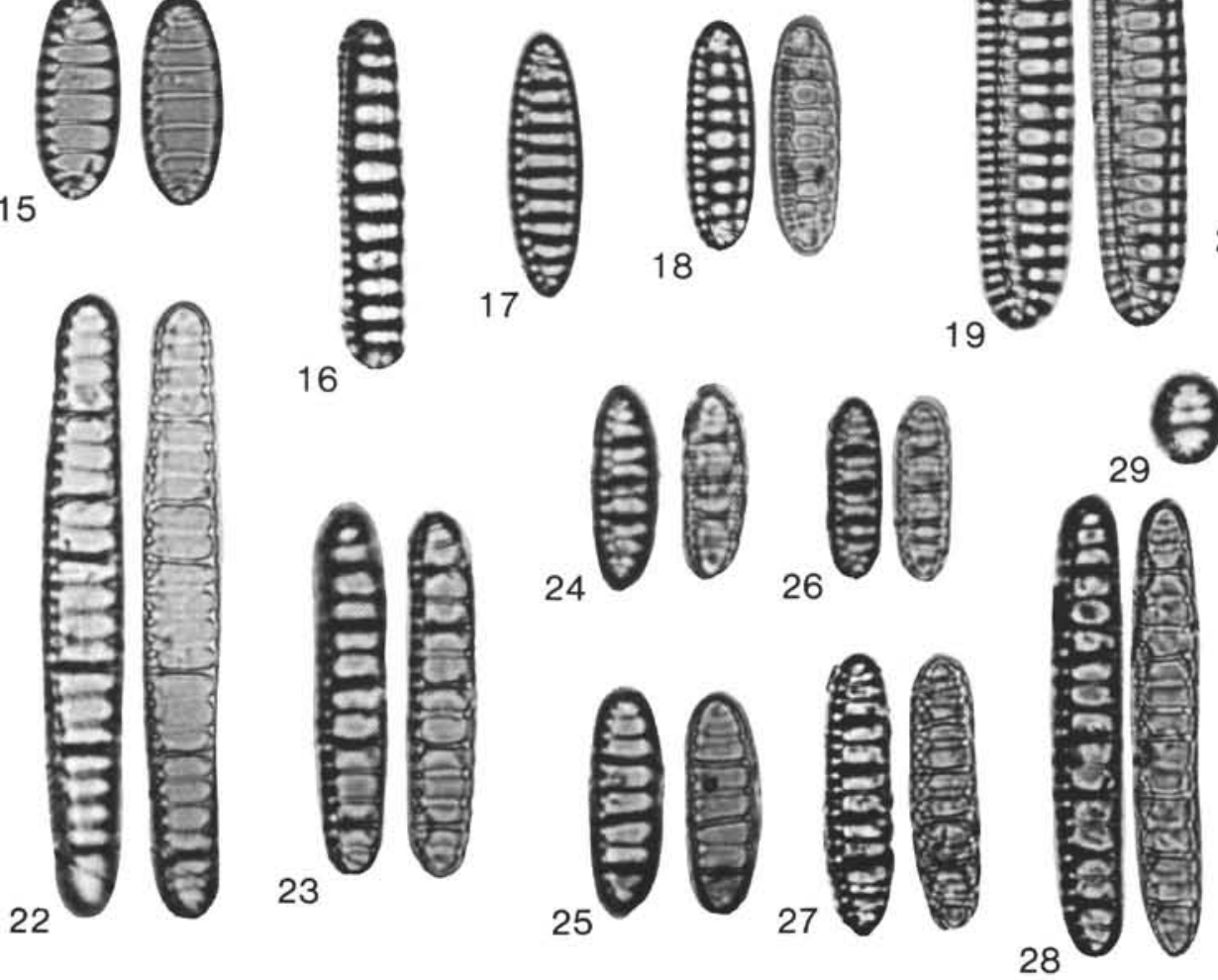

31

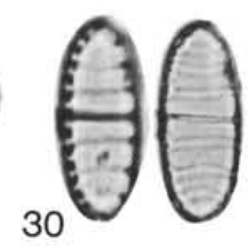

Plate 21. (All specimens magnified $\times 1500$.) 1-6. Nitzschia rolandii Schrader emend. Koizumi, (1) Sample 438A-43,CC, (2, 4, 6) Sample JDS-11685, Atsunai Formation, Atsunai Area, eastern Hokkaido, (3) Sample JDS-7163, Nina Formation, Kiyomappu Area, central Hokkaido, (5) Sample 438A-41,CC. 7-21. Neodenticula kamtschatica (Zabelina) Akiba and Yanagisawa n. comb., (7, 10, 11) Sample 438A-41,CC, (8, 13-19, 21) Sample 584-4,CC, (12) Sample 438A-43,CC, (20) Sample 584-43,CC. 22-28. Neodenticula koizumii Akiba and Yanagisawa stat., nom. et comb. n., Sample JDS-8629, Shiranuka Formation, Atsunai Area, eastern Hokkaido, (27) paratype, (28) holotype. 29-31. Neodenticula sp. A, Sample JDS-8634, Shiranuka Formation, Atsunai Area, eastern Hokkaido. 

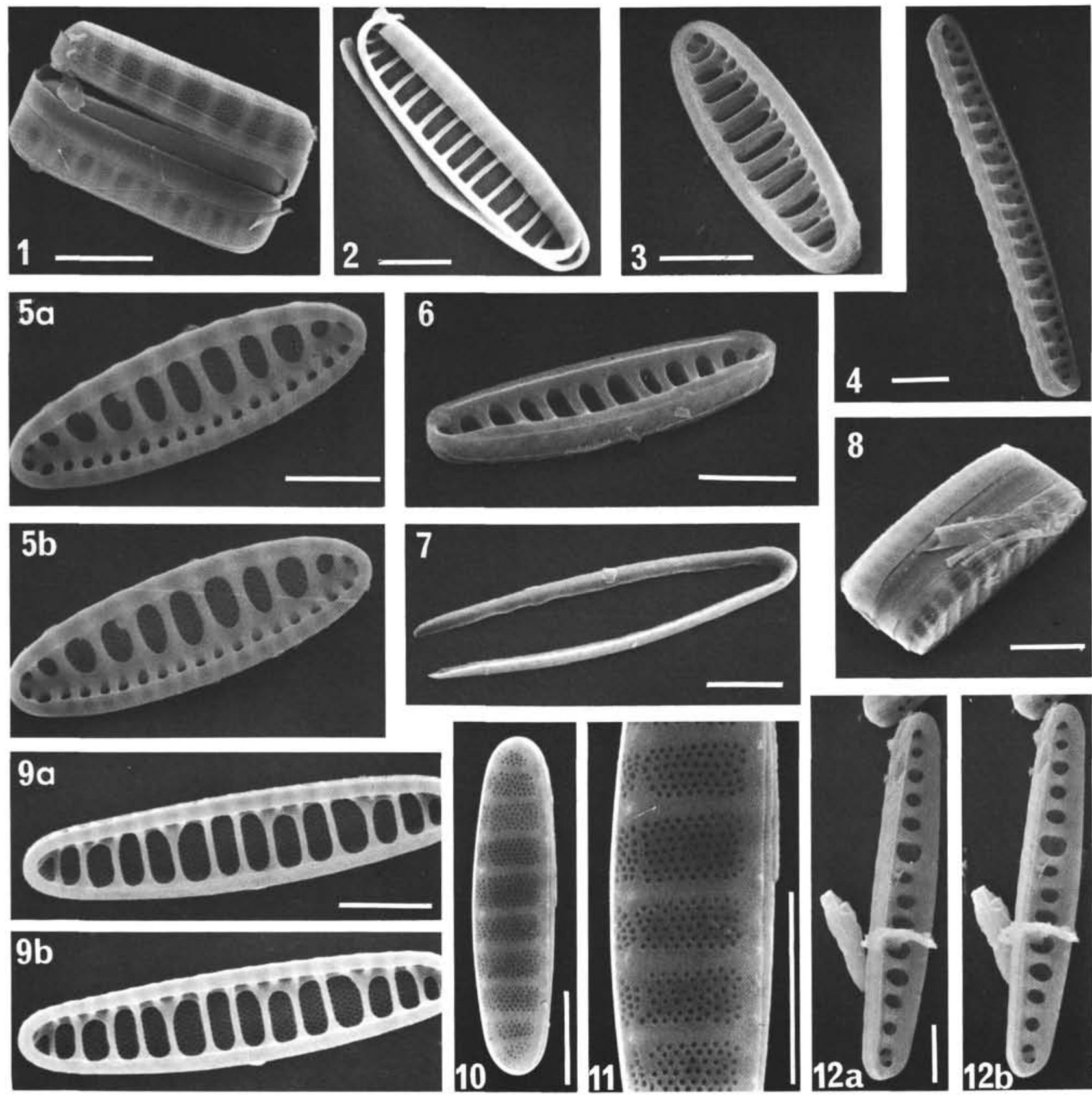

Plate 22. (Scale bar $=5 \mu \mathrm{m}$.) Neodenticula kamtschatica (Zabelina) Akiba and Yanagisawa n. comb. 1-2, 5A-B, 8. Sample JDS-8629, Shiranuka Formation, eastern Hokkaido, (1) girdle view of frustule, (2) internal view of valve with punctate copula, crossbars not distinct, (5A-B) valve interior (stereoscopic pair), (8) frustule, note punctate open copula, smooth open first and second pleurae and punctate third pleura. 3-4, 6-7, 9-12. Sample JDS-8623, Shiranuka Formation, eastern Hokkaido, (3) oblique narrow girdle view of valve, (4) oblique girdle view of valve, (6) oblique girdle view of valve, (7) open smooth copula, (9A-B) valve interior, note branchings of pseudosepta, (10) valve exterior, (11) enlarged view of specimen shown in Figure 10, note raphe slit is continuous, (12A-B) internal views of valve with open copula (stereoscopic pair). 

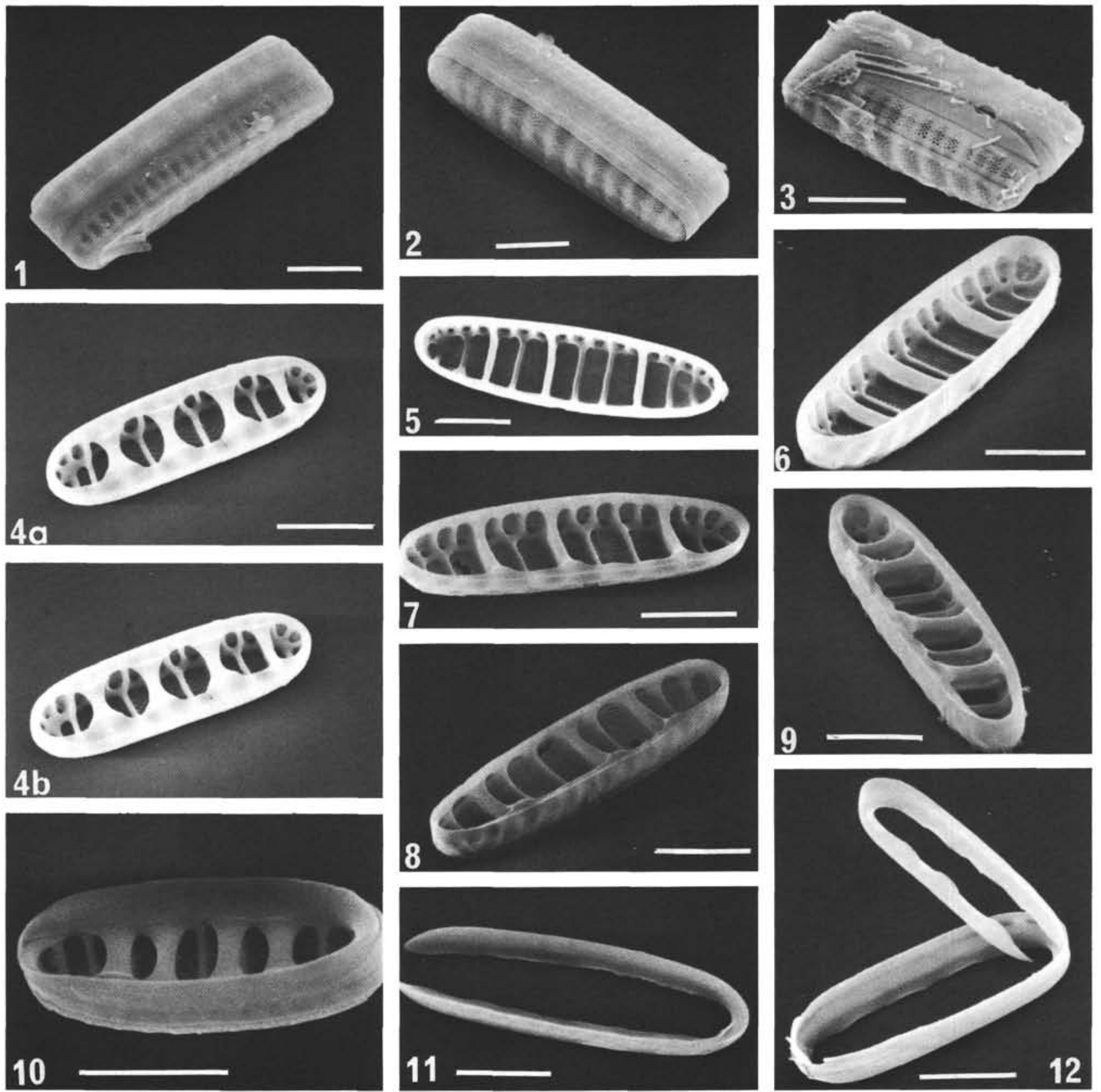

Plate 23. (Scale bar $=5 \mu \mathrm{m}$.) Neodenticula koizumii Akiba and Yanagisawa stat., nom. et comb. no. Sample JDS-8629, Shiranuka Formation, Atsunai Area, eastern Hokkaido. 1-2. Frustule with punctate copula and two smooth pleurae. 3. Frustule, note raphe slit not divided at middle point. 4A-B. Internal views of valve with well-developed crossbars, note portula between each two branches of pseudosepta (stereoscopic pair). 5-6. Internal views of valve without crossbars. 7. Internal view of valve with poorly developed crossbars. 8. Oblique internal view of specimen shown in Figure 7. 9. Oblique narrow girdle view of valve. 10. Internal view of hypovalve with smooth open copula covered with epipleurae. 11. Open smooth copula. 12. Cingulum. 

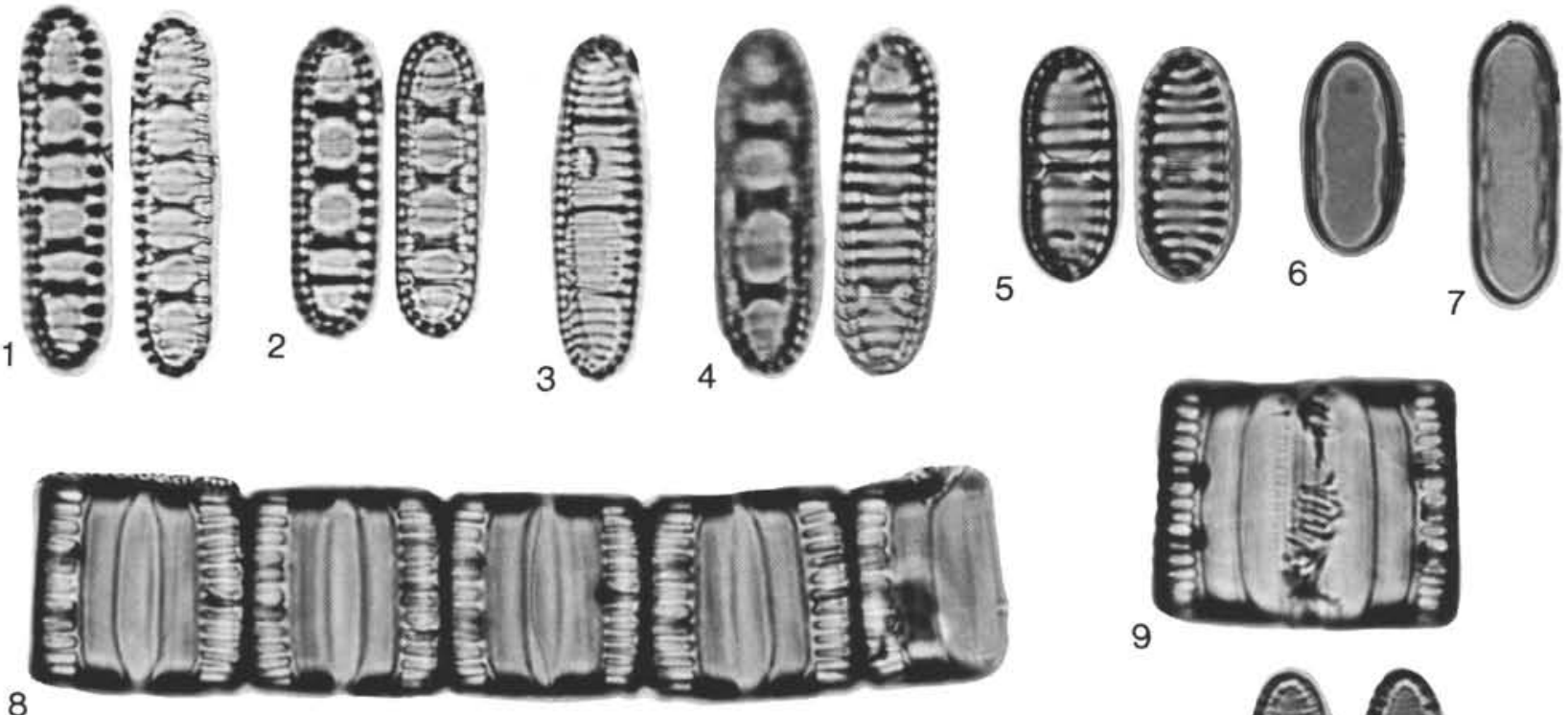

8

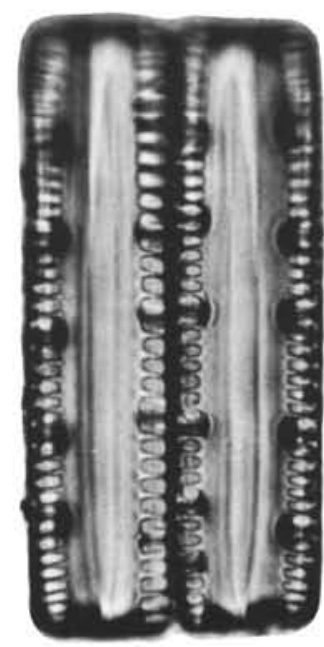

10
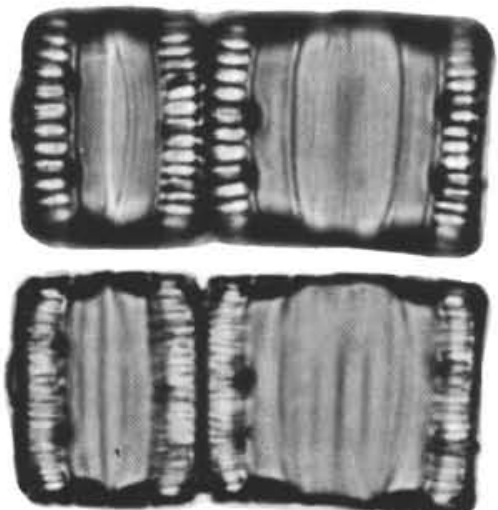

11

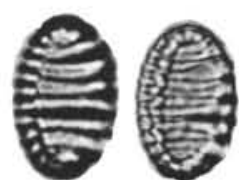

12

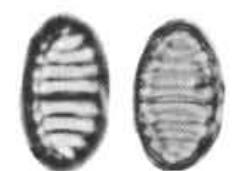

14

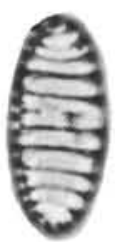

15

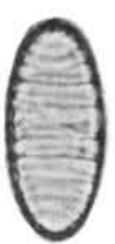

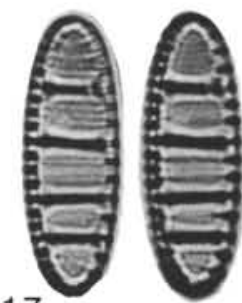

17

18
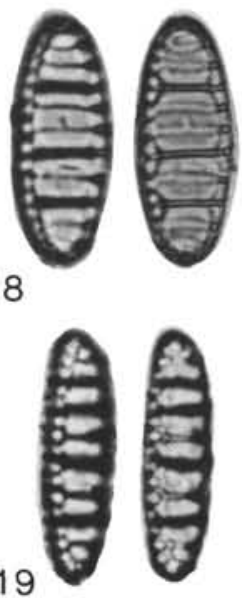

Plate 24. (All specimens magnified $\times 1500$.) 1-11. Neodenticula seminae (Simonsen and Kanaya) Akiba and Yanagisawa, n. comb., (1-3) Sample 584-1-1, 83-85 cm; (4, 6-7) Sample 584-1-1, 0-3 cm (6-7, isolated copulae), (5, 8-11) Sample JDS-12711, a dredge material off Otsuchi, northeastern Honshu (8-11, either colony or frustule). 12-18. Neodenticula sp. A., Sample JDS-8634, Shiranuka Formation, Atsunai Area, eastern Hokkaido, (16) frustule, note one valve has no primary pseudoseptum with crossbar. 19. Neodenticula koizumii Akiba and Yanagisawa stat. nom. et comb. n., Sample JDS-8629, Shiranuka Formation, Atsunai Area, eastern Hokkaido. 

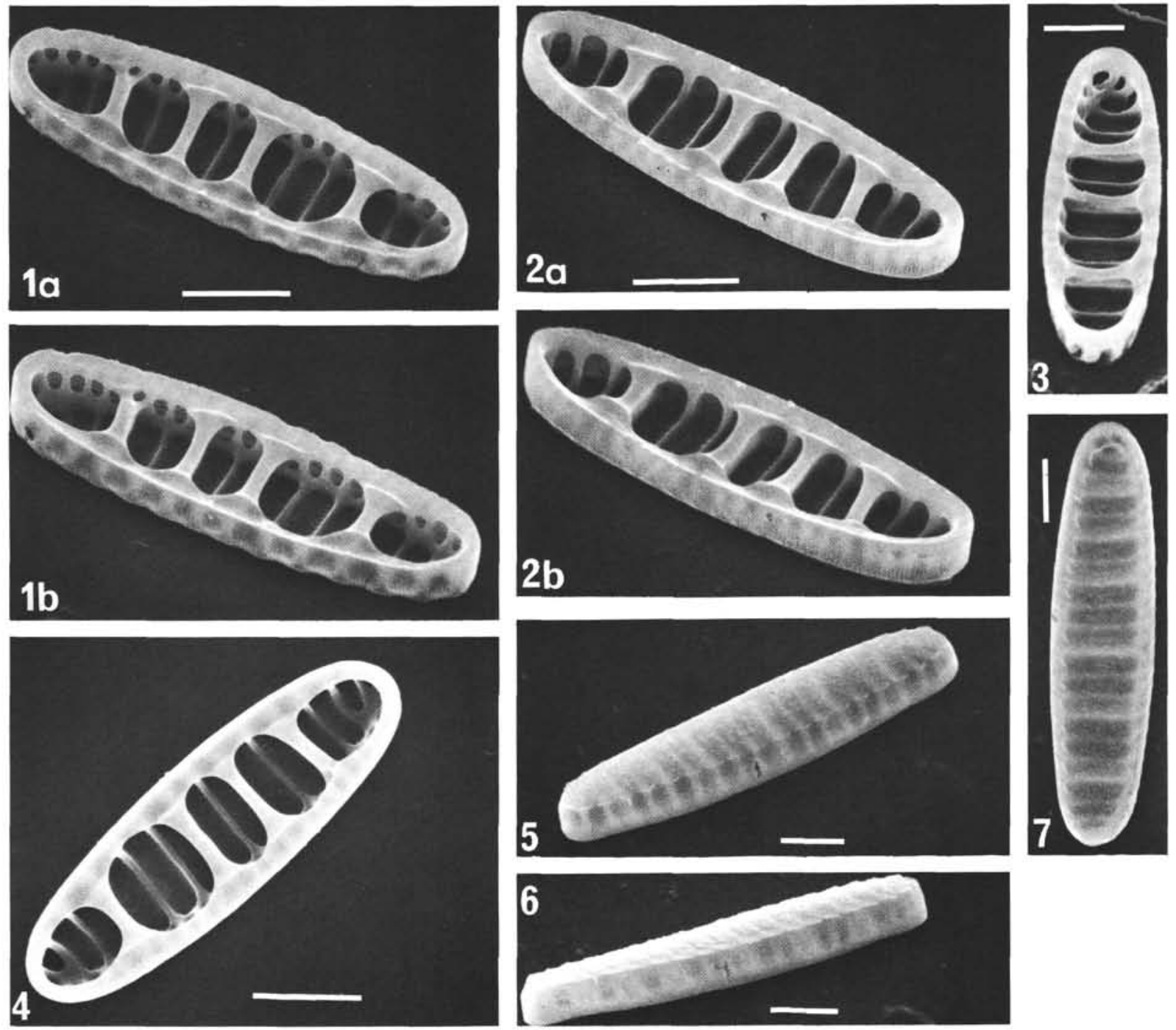

Plate 25. (Scale bar $=5 \mu \mathrm{m}$.) Neodenticula sp. A., Sample JDS-8634, Shiranuka Formation, Atsunai Area, eastern Hokkaido. 1A-B. Oblique internal views of valve, note portula between each two branches of pseudosepta (stereoscopic pair). 2A-B. Oblique internal views from the other side of specimen shown in Figure 1 (stereoscopic pair). 3. Oblique narrow girdle view of specimen shown in Figure 1. 4. Valve interior. 5. Oblique girdle view of valve. 6. Girdle view of valve shown in Figure 5. 7. External view of valve shown in Figure 5. 

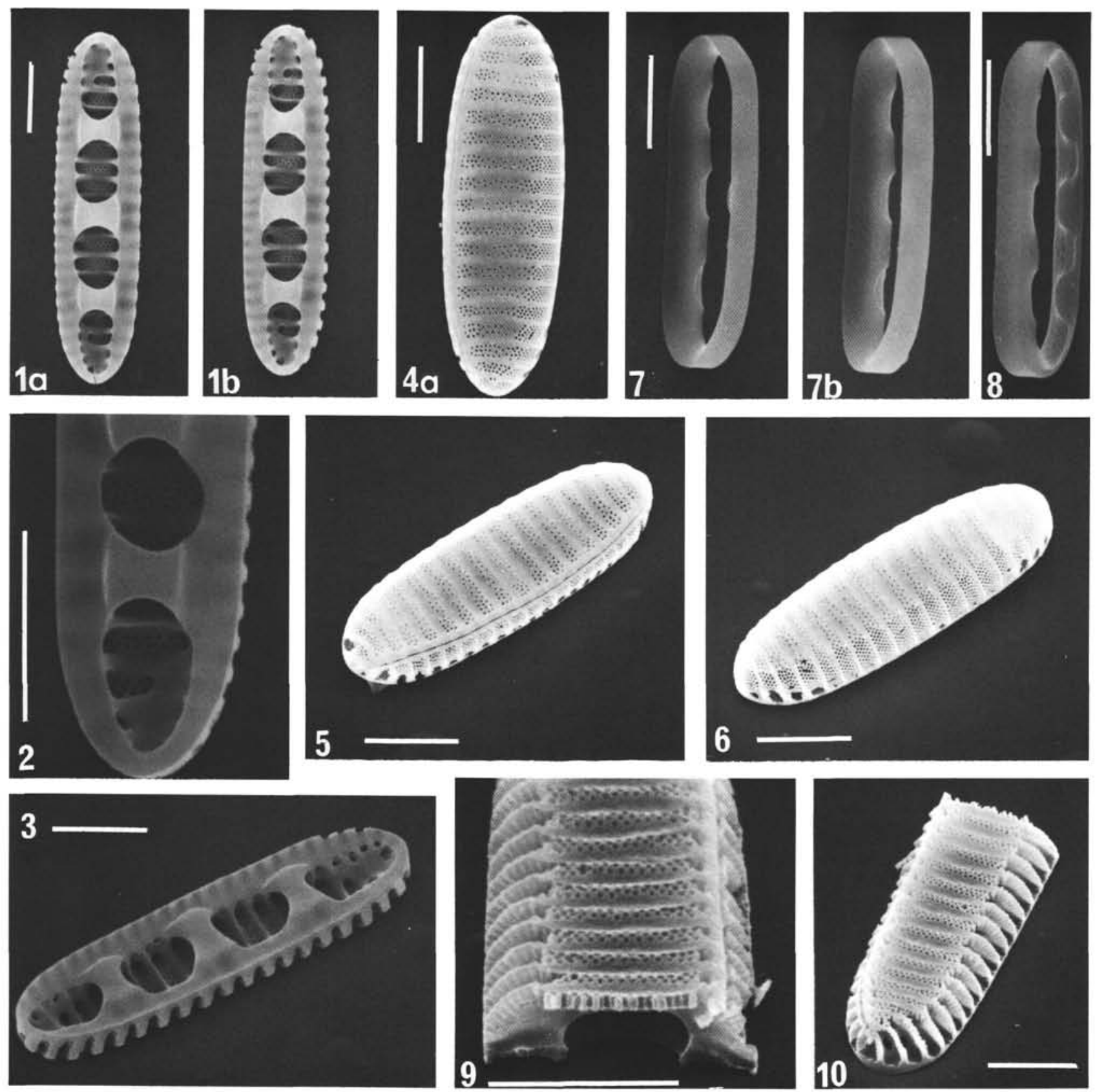

Plate 26. (Scale bar $=5 \mu \mathrm{m}$.) Neodenticula seminae (Simonsen and Kanaya) Akiba and Yanagisawa n. comb., Sample 183-5,CC. 1A-B. Valve interior (stereoscopic pair). 2. Enlarged view of valve shown in Figure 1. 3. Oblique view of valve shown in Figure 1. 4. Valve exterior. 5-6. Oblique views of valve shown in Figure 4, notice raphe slit continuous and sparse areolae on valve face. 7A-B. Closed copula (stereoscopic pair). 8. Closed copula. 9. Cross section of broken valve, note circular raphe canal. 10. Oblique view of valve, surface wall of which is dissolved. 

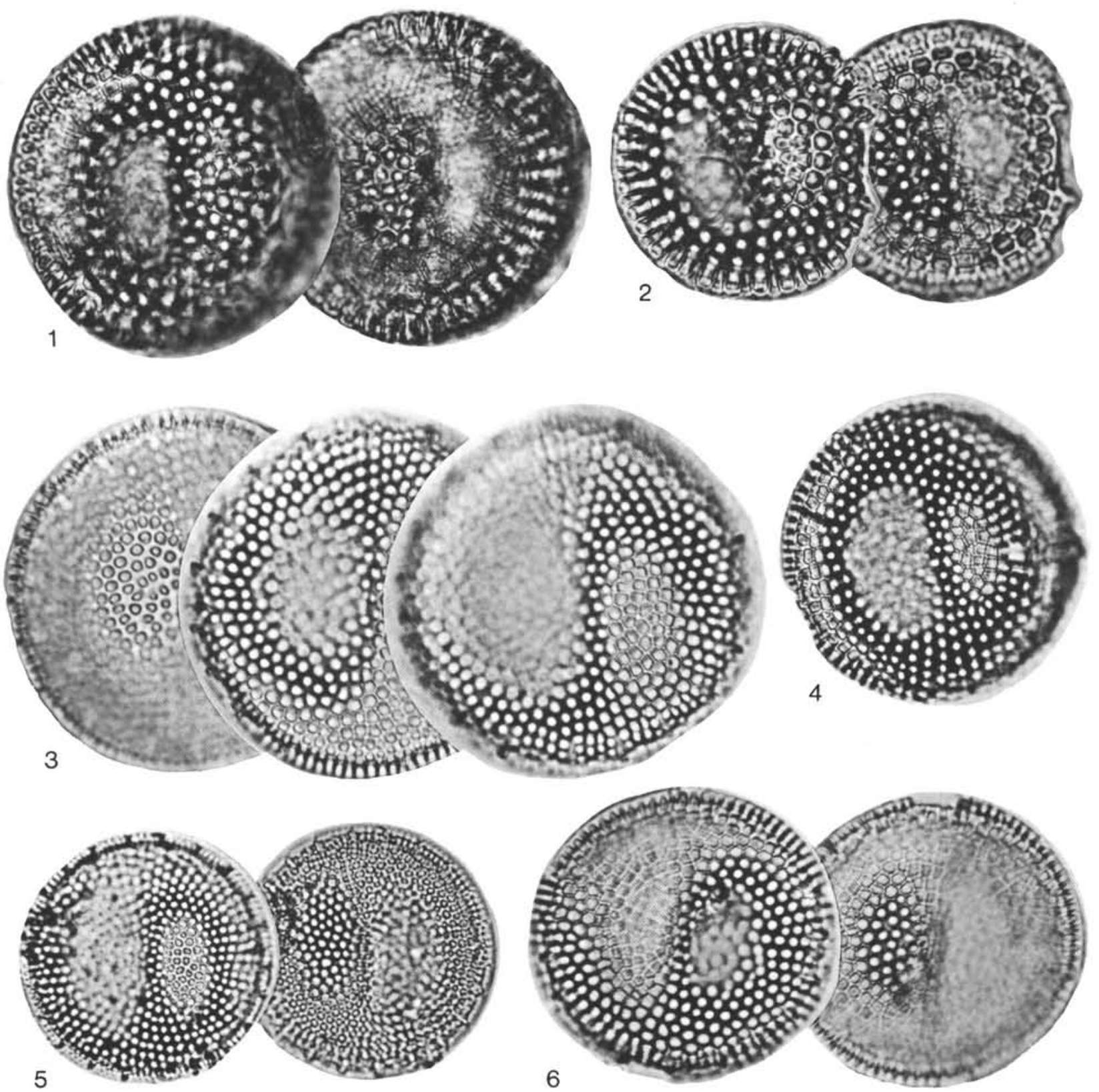

Plate 27. (All specimens magnified $\times 1500$.) 1-2. Thalassiosira yabei (Kanaya) Akiba and Yanagisawa n. comb., Sample JDS-9162, Chokubetsu Formation, Atsunai Area, eastern Hokkaido. 3-4, 6. Thalassiosira cf. yabei (Kanaya) Akiba and Yanagisawa, (3, 6) Sample JDS-11452, Chokubetsu Formation, Atsunai Area, eastern Hokkaido, (4) Sample JDS-11193, Mito Formation, Mito City, northeastern Honshu. 5. Thalassiosira grunowii Akiba and Yanagisawa comb. et nom. n., Sample JDS-11921, Isozaki Formation, Ajigaura Area, northeastern Honshu. 

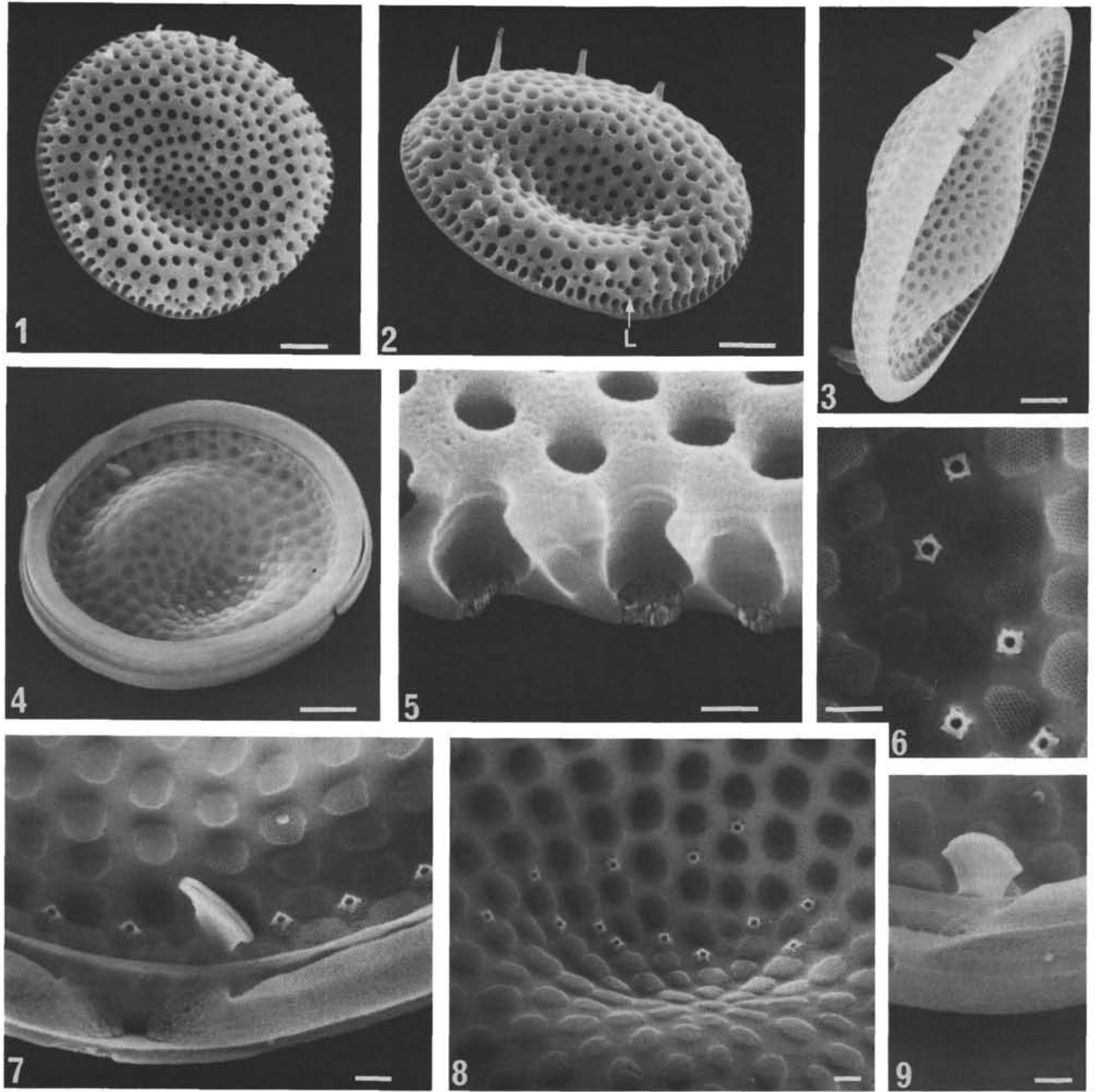

Plate 28. (Scale bar $=5 \mu \mathrm{m}$ in Figures $1-4$, and $1 \mu \mathrm{m}$ in Figures 5-9.) Thalassiosira yabei (Kanaya) Akiba and Yanagisawa $\mathrm{n}$. comb., Sample JDS-9142, Chokubetsu Formation, Atsunai Area, eastern Hokkaido. 1. Valve exterior, note outer openings of strutted processes scattered on convex side. 2. Oblique view of valve exterior, arrow shows outer opening of labiate process, note long spines. 3. Girdle view of valve. 4. Valve interior with cingulum bands. 5. Cross section of areolae with internal cribra and external foramina. 6, 8. Internal views of strutted processes scattered on convex side. 7. Internal view of labiate process and marginal strutted processes. 9. Internal view of labiate process. 

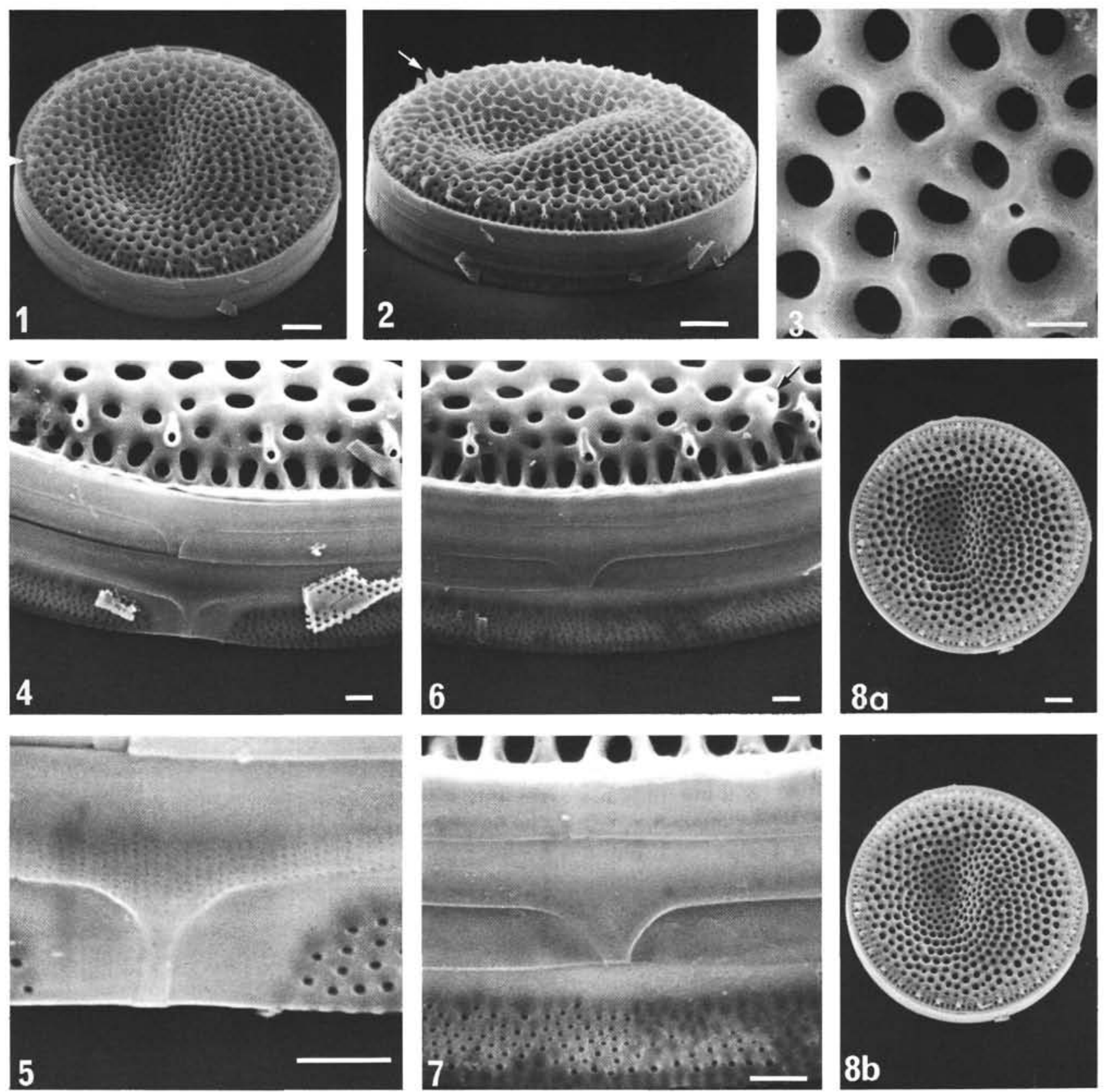

Plate 29. (Scale bar $=5 \mu \mathrm{m}$ in Figures 1-2, 8, and $1 \mu \mathrm{m}$ in Figures 3-7.) Thalassiosira grunowii Akiba and Yanagisawa comb. et nom. n., Sample JDS-11921, Isozaki Formation, Ajigaura Area, eastern Honshu. 1-2. External views of hypovalve with epicingulum; arrow indicates labiate process. 3. Outer surface of valve; small pores are outer openings of strutted processes scattered on convex side. 4. The portion where valvocopula is open; valvocopula, copula, and three pleurae; note lingula and antilingula of each band. 5. Enlarged view of Figure 4; copula is perforated by longitudinal short striae. 6. The portion where copula is open, about $180^{\circ}$ apart from the portion of Figure 4; arrow shows labiate process. 7. Enlarged view of Figure 6. 8A-B. Valve exterior (stereoscopic pair); strutted processes are scattered only on convex side. 

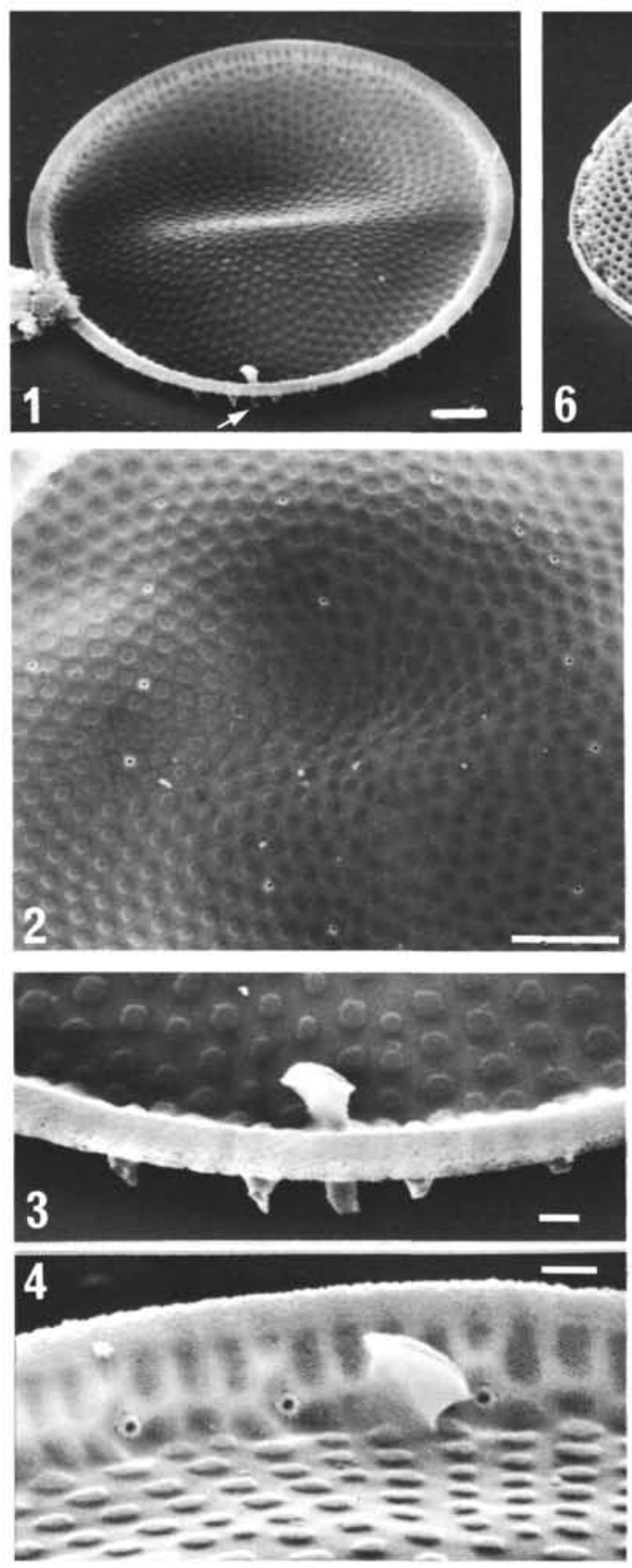
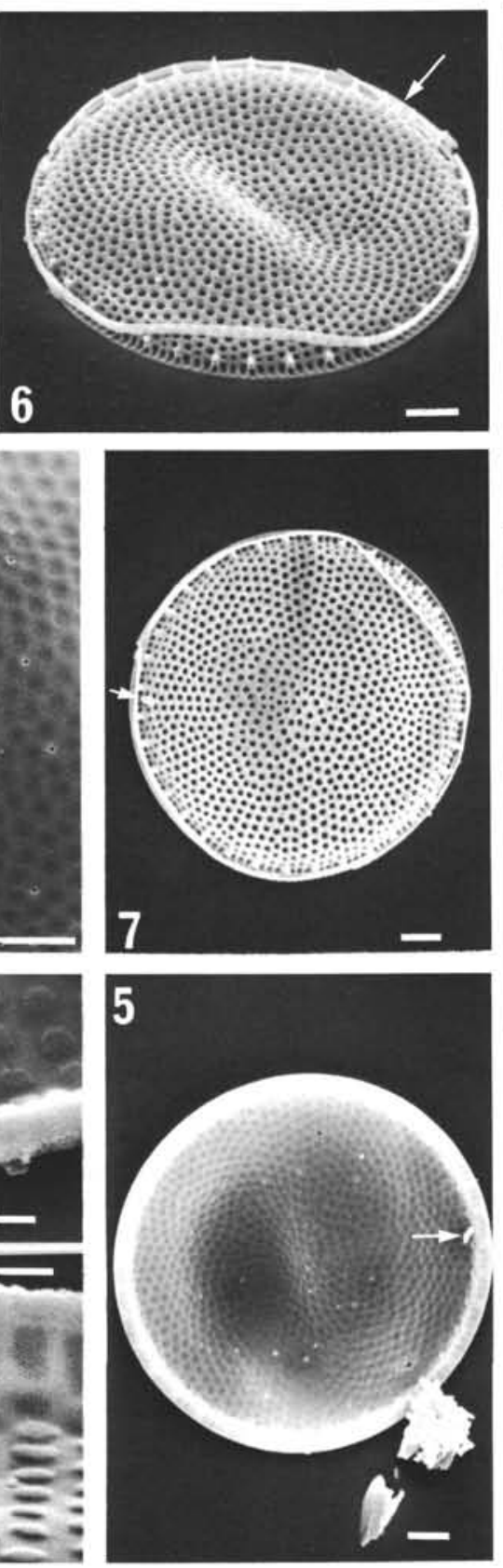
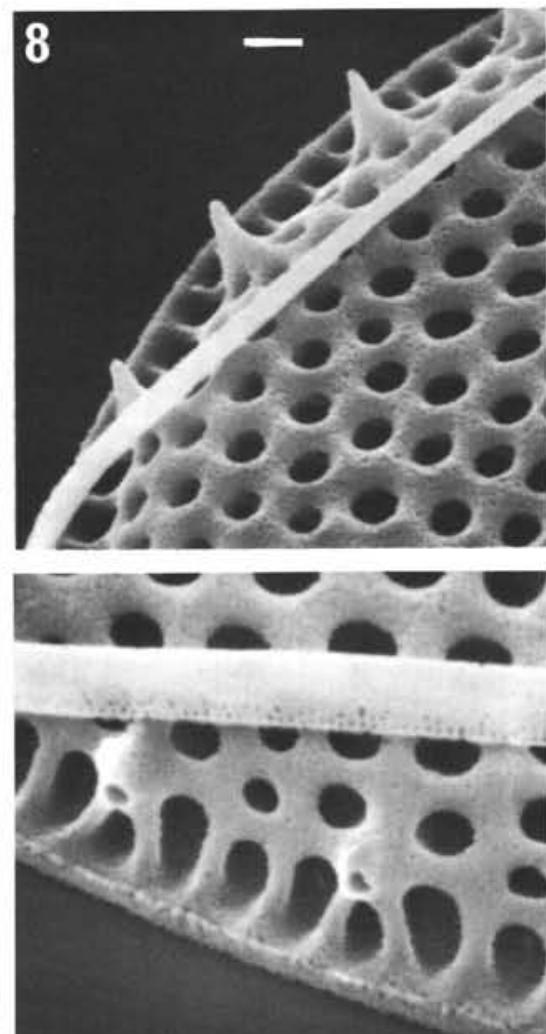

9

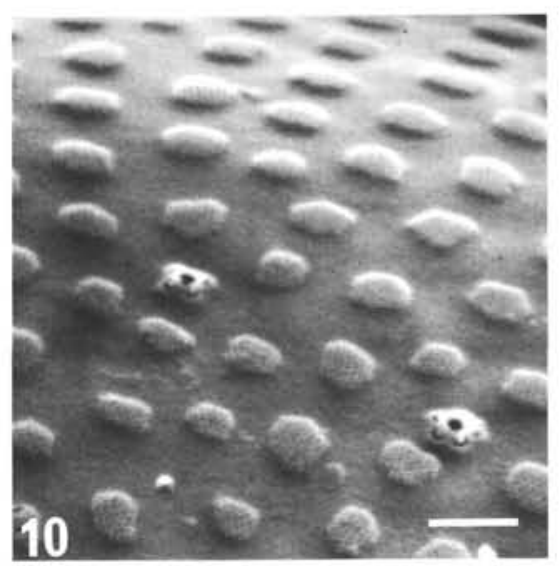

Plate 30. (Scale bar $=5 \mu \mathrm{m}$ in Figures 1, 2, 5, 6, 7, and $1 \mu \mathrm{m}$ in Figures 3, 4, 8-10.) Thalassiosira grunowii Akiba and Yanagisawa comb. et nom n., Sample JDS-11921, Isozaki Formation, Ajigaura Area, eastern Honshu. 1, 5. Valve interior, arrows indicate labiate process. 2. Valve interior, scattered strutted processes over valve face. 3-4. Labiate process and marginal strutted processes. 6-7. Valve exterior, arrows indicate labiate process. 8-9. Outer openings of marginal strutted processes with short spines. $\mathbf{1 0}$. Valve interior, scattered strutted processes and polygonal cribra. 

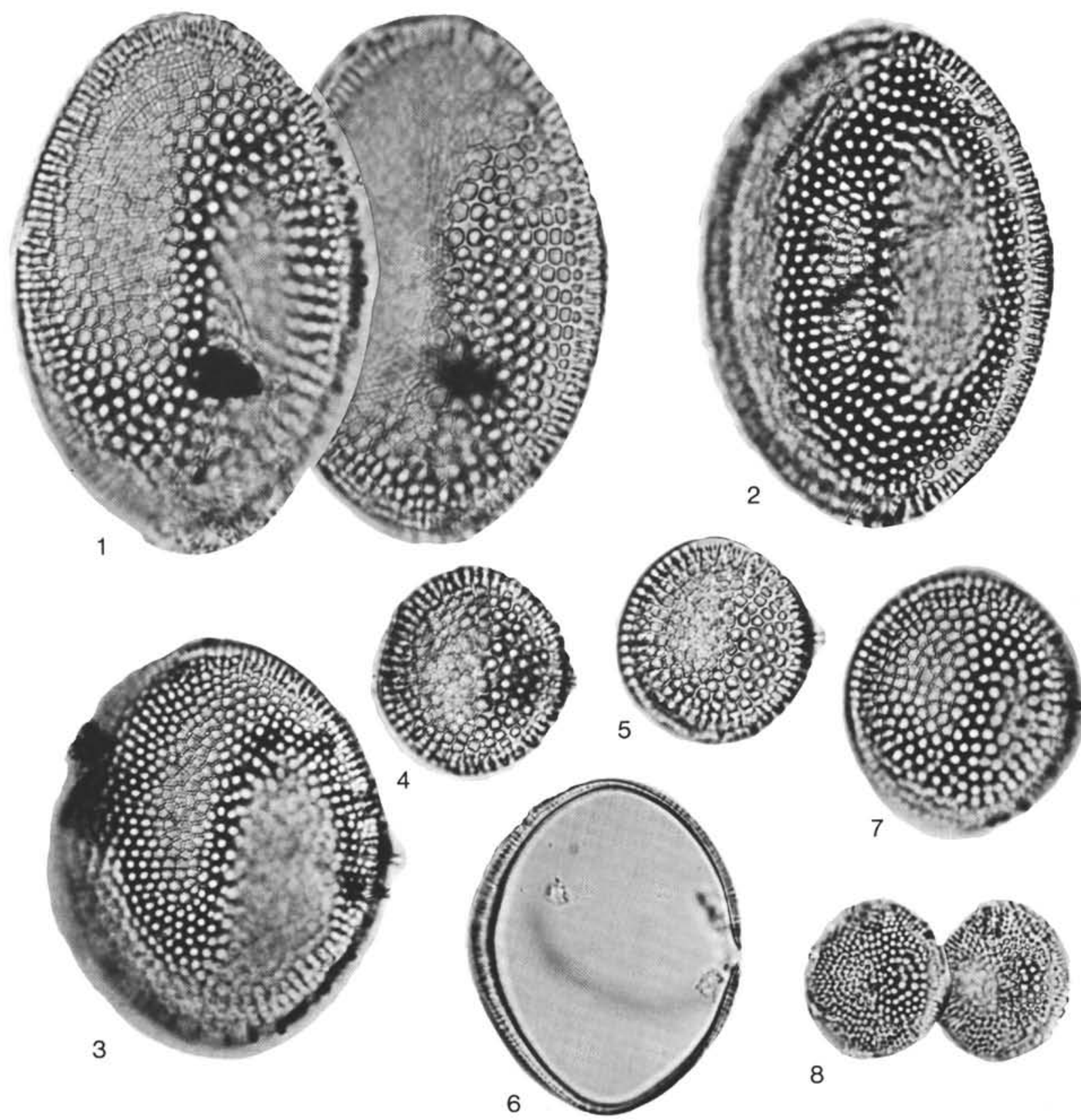

Plate 31. (All specimens magnified $\times 1500$.) 1-7. Thalassiosira temperei (Brun) Akiba and Yanagisawa n. comb., (1) Sample JDS-7163, Nina Formation, Kiyomappu Area, central Hokkaido, (2) Sample JDS-11193, Mito Formation, Mito City, northeastern Honshu, (3-7) Sample JDS-11685, Atsunai Formation, Atsunai Area, eastern Hokkaido. 8. Thalassiosira brunii Akiba and Yanagisawa comb. et nom. n., Sample 438A-57-4, 59-61 cm. 

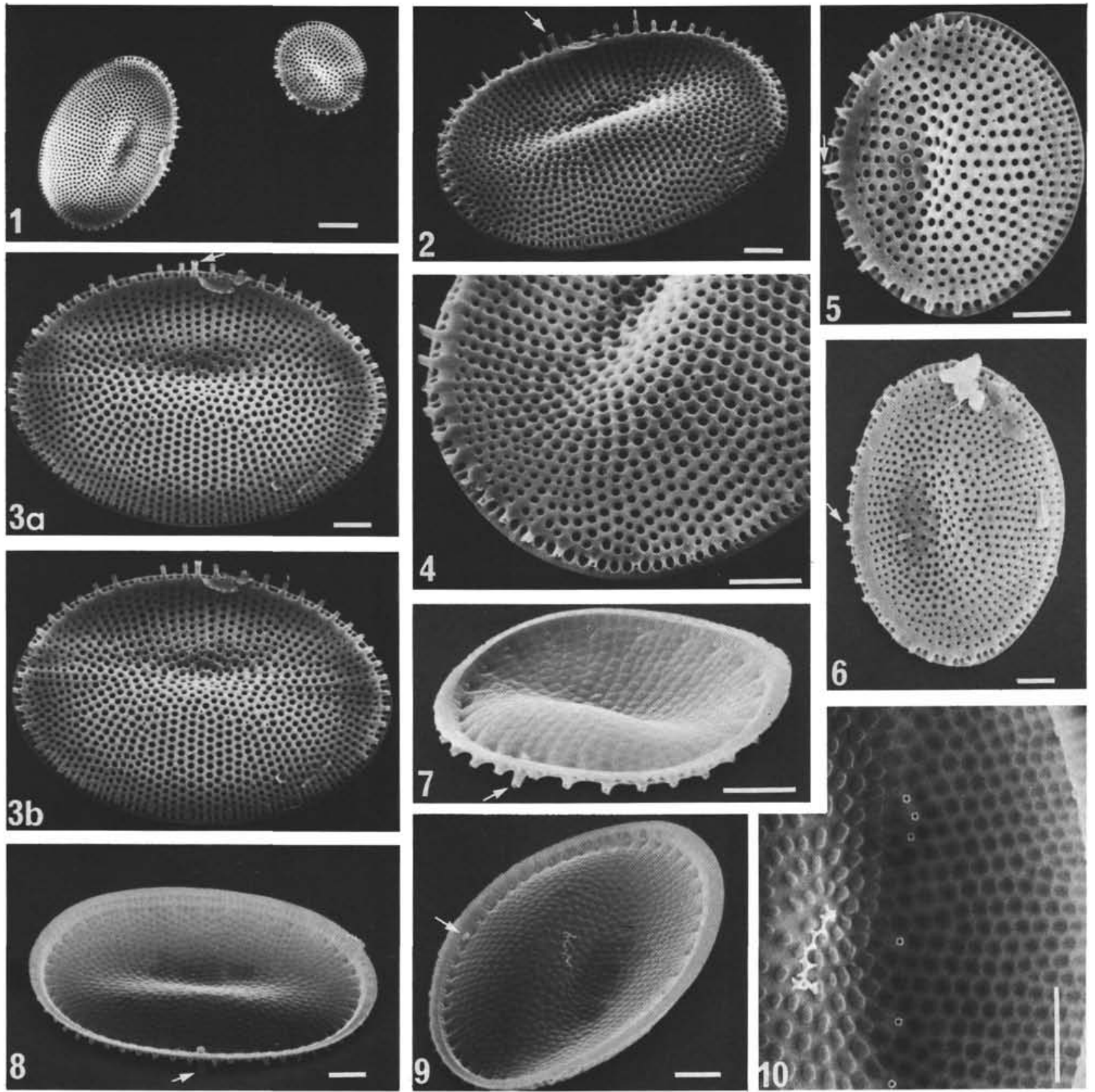

Plate 32. (Scale bar $=5 \mu \mathrm{m}$ unless otherwise indicated, arrows indicate labiate processes.) Thalassiosira cf. brunii Akiba and Yanagisawa comb. et nom. n., Sample JDS-11921, Isozaki Formation, Ajigaura Area, eastern Honshu. 1. Large and small specimens (bar $=10 \mu \mathrm{m}$ ). 2. Oblique view of valve exterior. 3A-B. Valve exterior, small pores scattered on convex side are outer openings of strutted processes (stereoscopic pair). 4. Enlarged view of Figure 2, outer tubes of marginal strutted processes decrease in length from left to right. 5. Exterior of relatively small valve. 6. Valve exterior. 7, 9. Oblique views of valve interior. 10. Valve interior showing scattered strutted processes. 

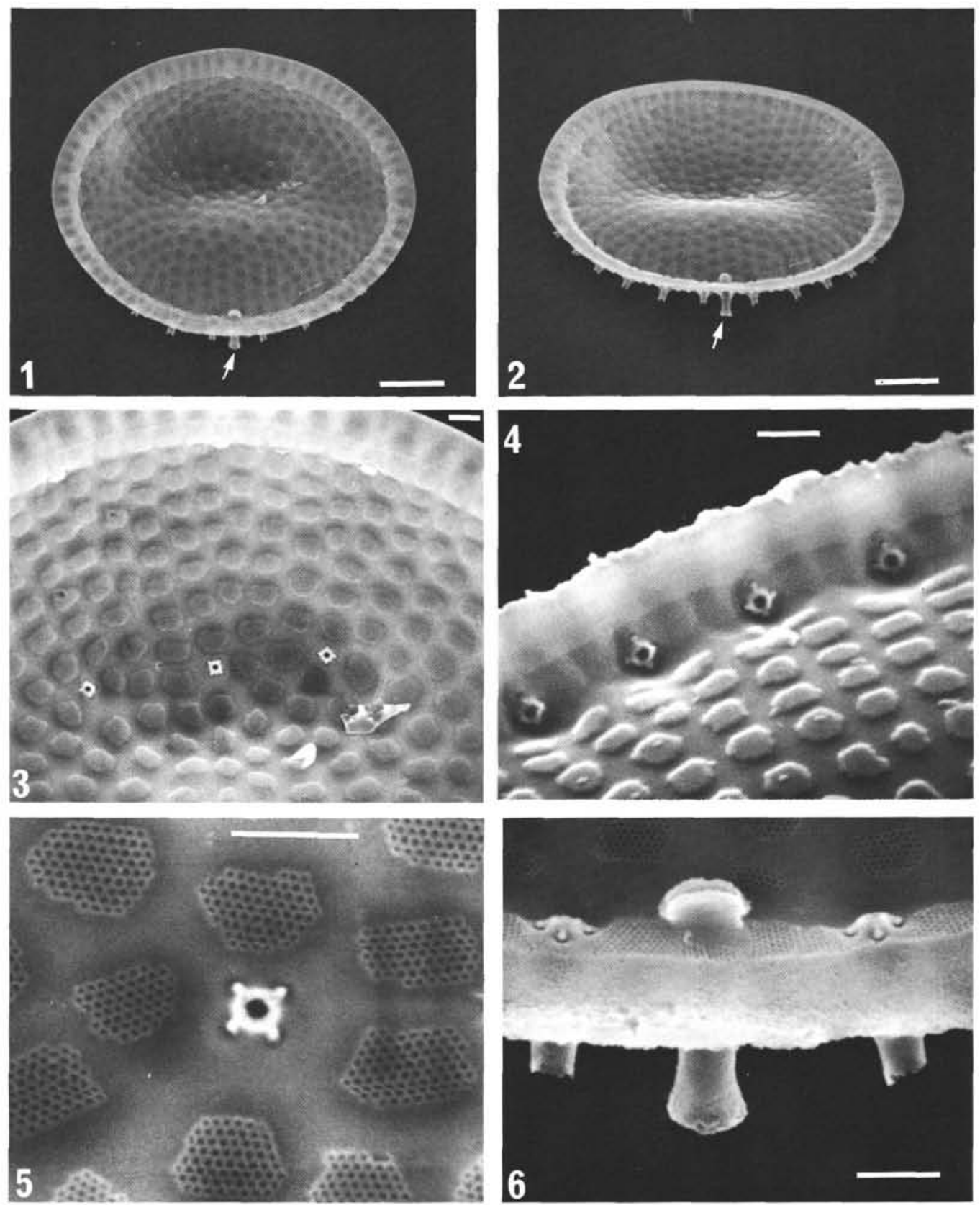

Plate 33. (Scale bar $=5 \mu \mathrm{m}$ in Figures 1-2, and $1 \mu \mathrm{m}$ in Figures 3-6.) Thalassiosira cf. brunii Akiba and Yanagisawa comb. et nom. n., Sample JDS-11921, Isozaki Formation, Ajigaura Area, eastern Honshu. 1-2. Valve interior, arrows indicate labiate process. 3. Internal view of convex side of valve with three strutted processes scattered. 4. Internal view of marginal strutted processes. 5. Enlarged view of Figure 3 . 6. Enlarged view of labiate process and marginal strutted processes. 


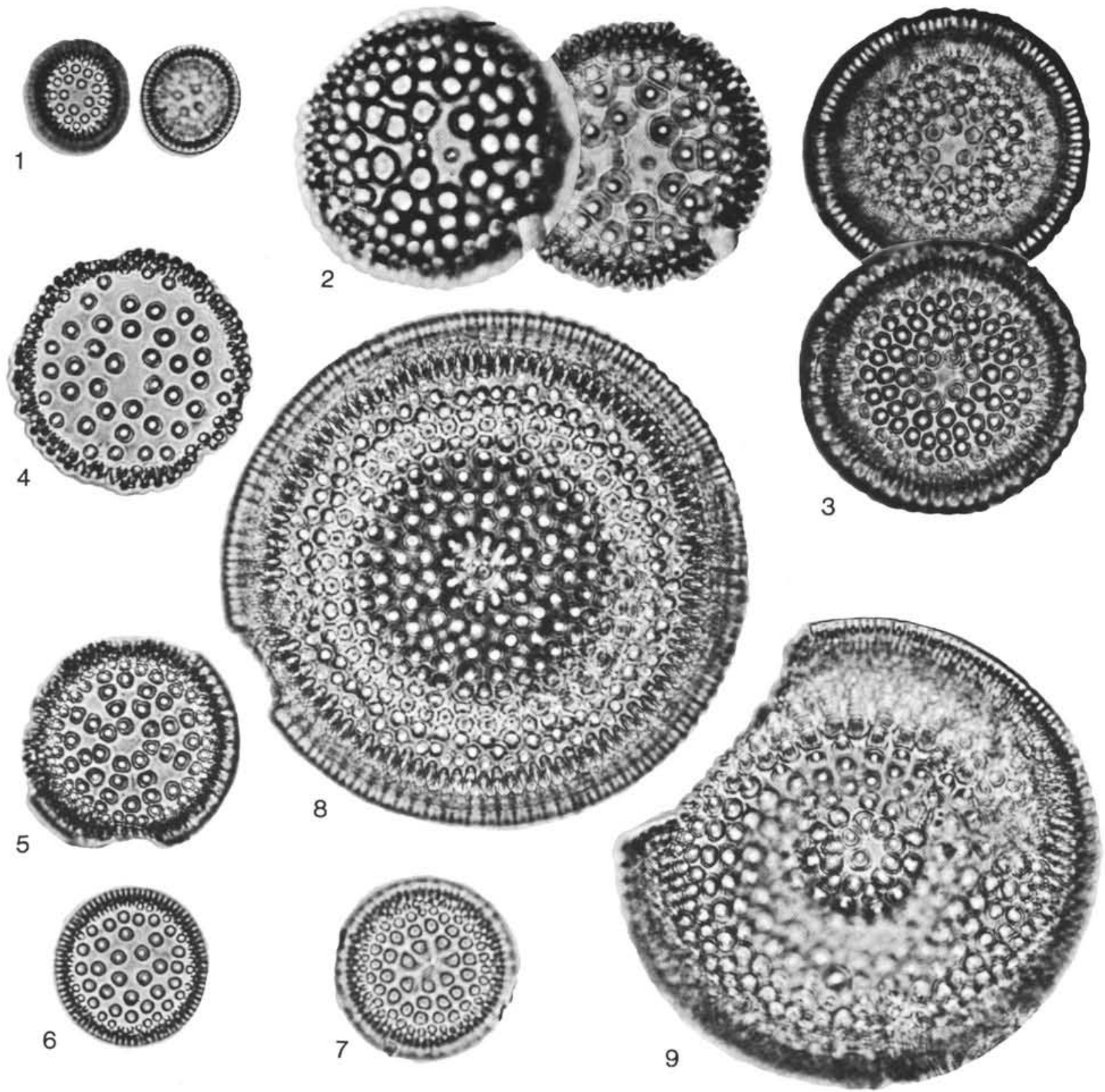

Plate 34. (All specimens magnified $\times 1500$.) 1-7. Actinocyclus ingens Rattray, (1) Sample JDS-1833, lower part of Taga Group, Joban Area, northeastern Honshu, $(2,7)$ Sample 183-18,CC, (3) Sample JDS-11407, an exotic block of Atsunai Formation, Atsunai Area, eastern Hokkaido, (4-5) Sample 438A-70-7, 5-7 cm, (6) Sample JDS-12507, Yuni Formation, Umaoiyama Area, central Hokkaido. 8-9. Actinocyclus ingens var. nodus Baldauf, Sample 438A-70-7, 5-7 cm. 

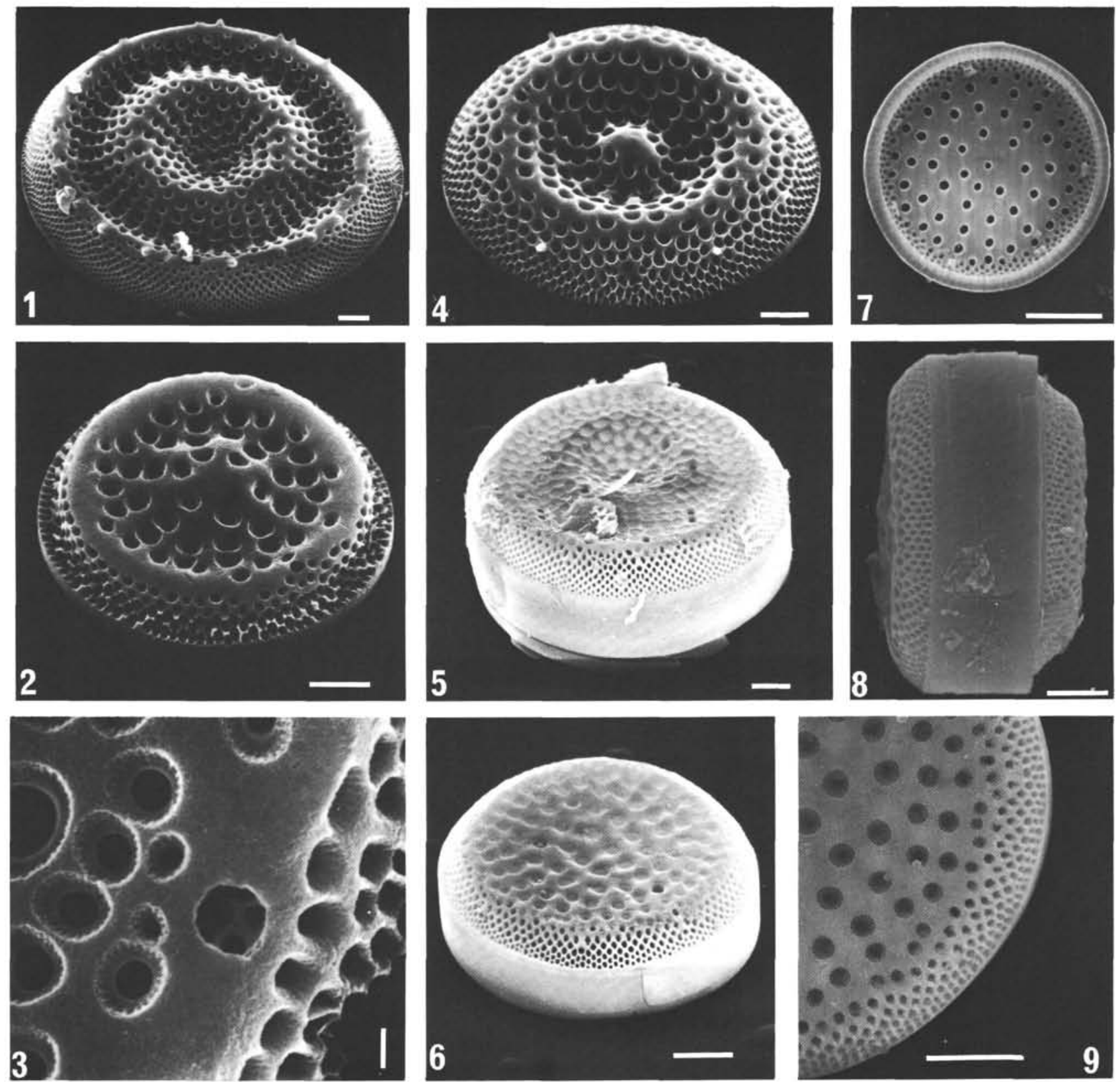

Plate 35. (Scale bar $=5 \mu \mathrm{m}$ unless otherwise indicated.) Actinocyclus ingens Rattray. 1-4. Sample 438A-70-7, 5-7 cm, northwestern Pacific, (1) valve exterior, undulated with concave center, note small spines on submarginal convex zone, (2) valve exterior of transition form fromflat type to $A$. ingens var. nodus Baldauf, (3) pseudonodule of areolate-operculate type, (4) valve exterior, undulated with convex center (=A. ingens var. nodus Baldauf). 5-9. Sample JDS-9769, Otsuka Formation, Matsushima Area, northeastern Honshu, (5) frustule, undulated epivalve with concave center, (6) frustule with flat epivalve, (7) valve interior, (8) girdle view of frustule, cingulum composed of broad and narrow bands, (9) enlarged view of specimen in Figure 6 showing outer circular cribra. 

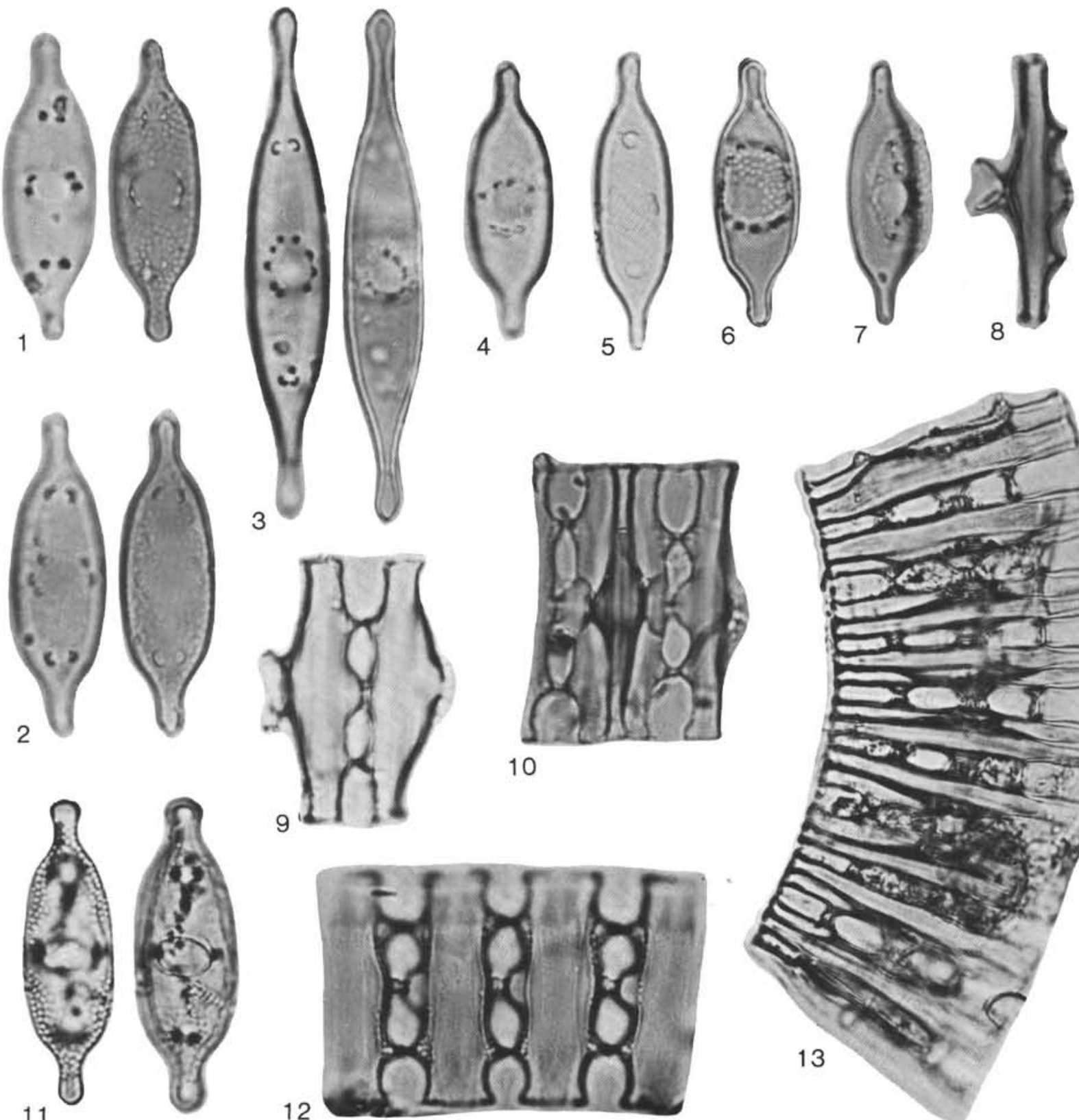

3
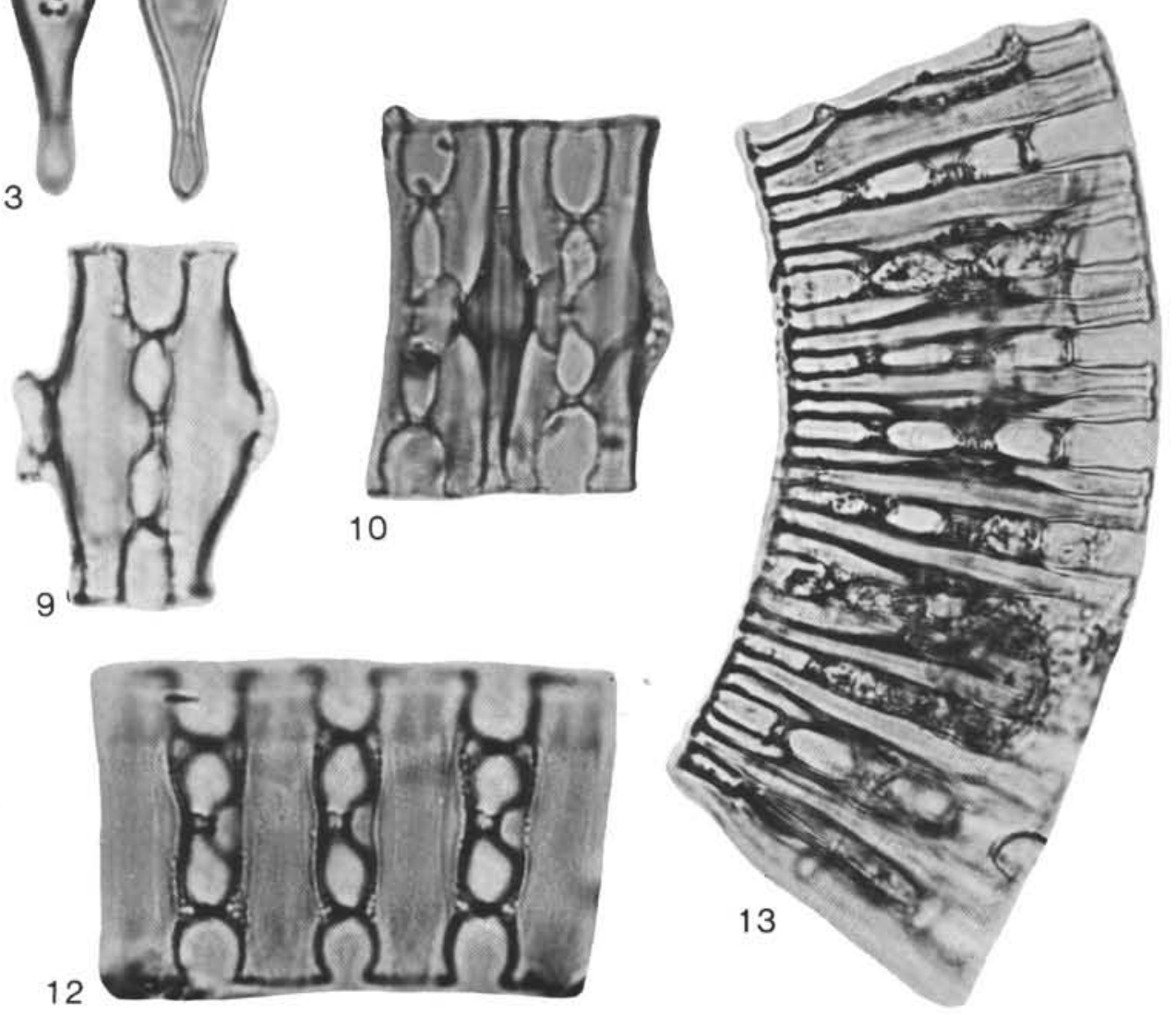

Plate 36. (All specimens magnified $\times 1500$.) 1-10. Kisseleviella carina Sheshukova-Poretzkaya, (1-10) Sample JDS-8789, a calcareous nodule from Okuyama Conglomerate of Sakuma Formation, Bōsō Peninsula, central Japan (1-2, vegetative valve; 3-9, resting spore; 10, colony of vegetative cells with resting spores). 11-13. Same species as Figures 1-10, Sample JDS-10648, Hata Formation, Bōsō Peninsula, (11-12) vegetative valve, (13) colony of vegetative cells with resting spores. 

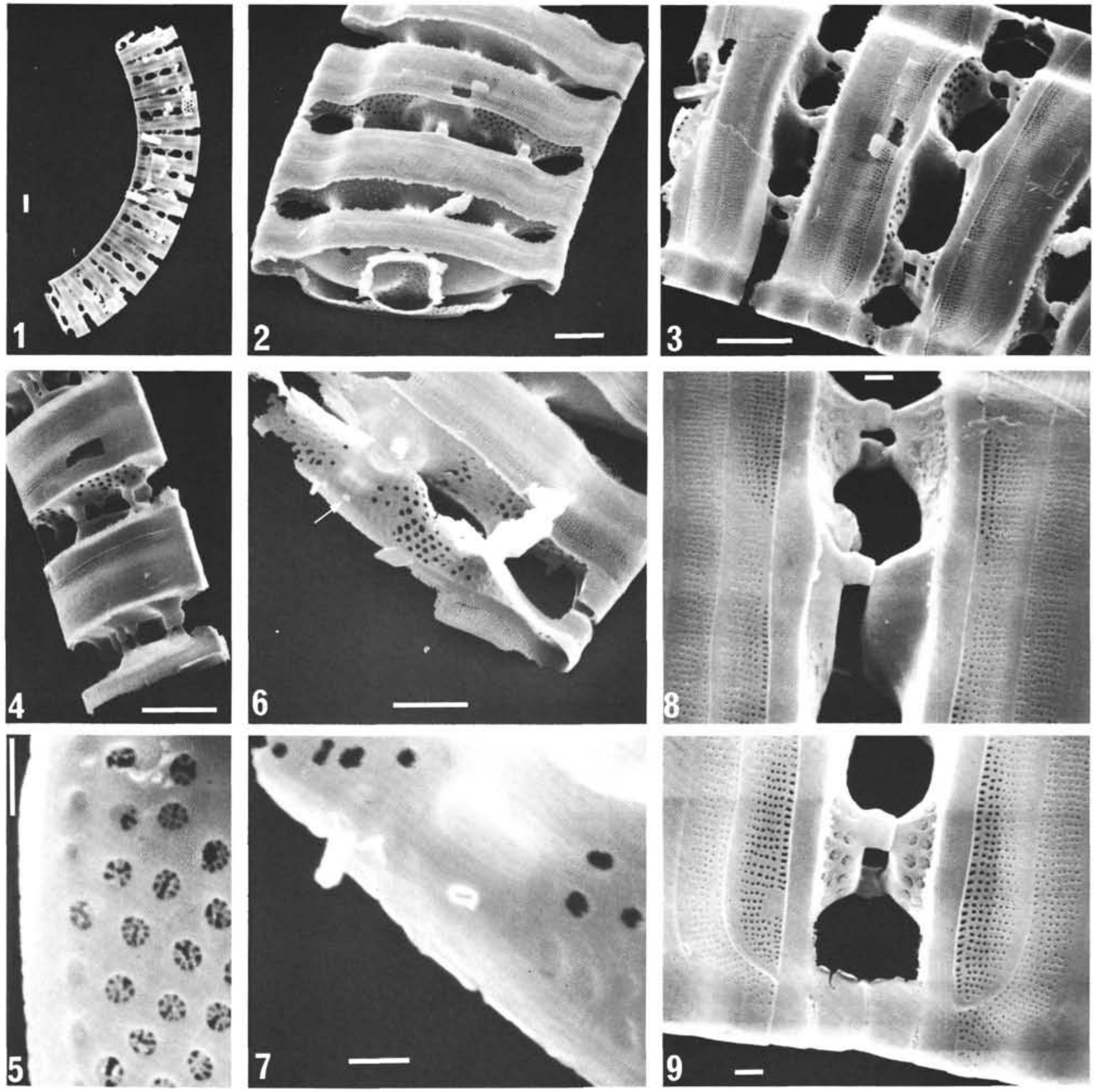

Plate 37. Kisseleviella carina Sheshukova-Poretskaya, Sample JDS-10648, Hata Formation, Bōsō Pensinula, central Japan. 1. Chain $($ bar $=$ $10 \mu \mathrm{m})$. 2. A part of chain composed of vegetative valves (areolated) and resting spores (smooth or dotted) (bar $=5 \mu \mathrm{m})$. 3. Enlarged view of specimen in Figure 2, showing mode of combination $(\mathrm{bar}=5 \mu \mathrm{m})$. 4. A part of chain $(\mathrm{bar}=5 \mu \mathrm{m})$. 5. Areolae of vegetative valve $(\mathrm{bar}=$ $1 \mu \mathrm{m})$. 6. A part of chain, arrow indicates labiate process $(\mathrm{bar}=5 \mu \mathrm{m})$. 7. Enlarged view of Figure 6 , showing labiate process (bar $=$ $1 \mu \mathrm{m})$. 8-9. Enlarged views of specimen shown in Figure 3 (bar $=1 \mu \mathrm{m})$. 

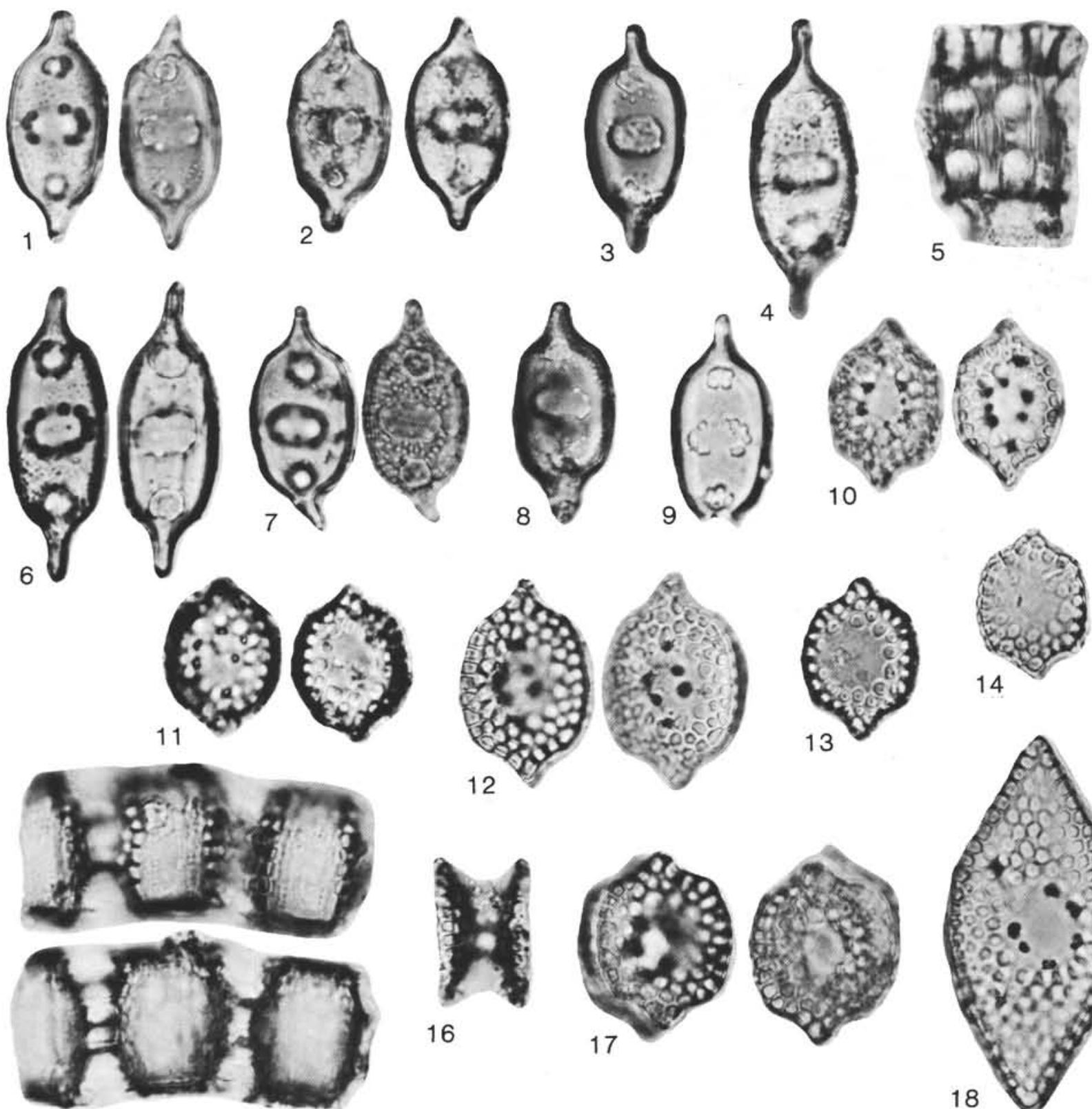

15

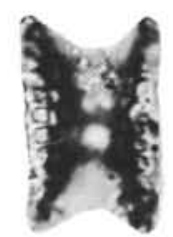

16

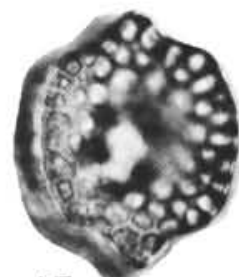

17

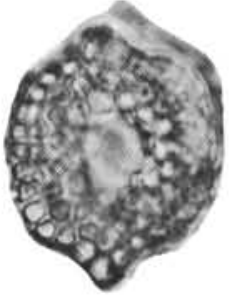

18

Plate 38. (All specimens magnified $\times 1500$.) 1-9. Kisseleviella ezoensis Akiba, Sample JDS-8482, Kiroro Formation, Honbetsu Area, eastern Hokkaido, (5) colony. 10-18. Kisseleviella magnaareolata Akiba and Yanagisawa n. sp., Sample JDS-10649, a calcareous nodule in Takatsuru Formation, Bōsō Peninsula, central Japan, (10) holotype, (15-16) colony. 

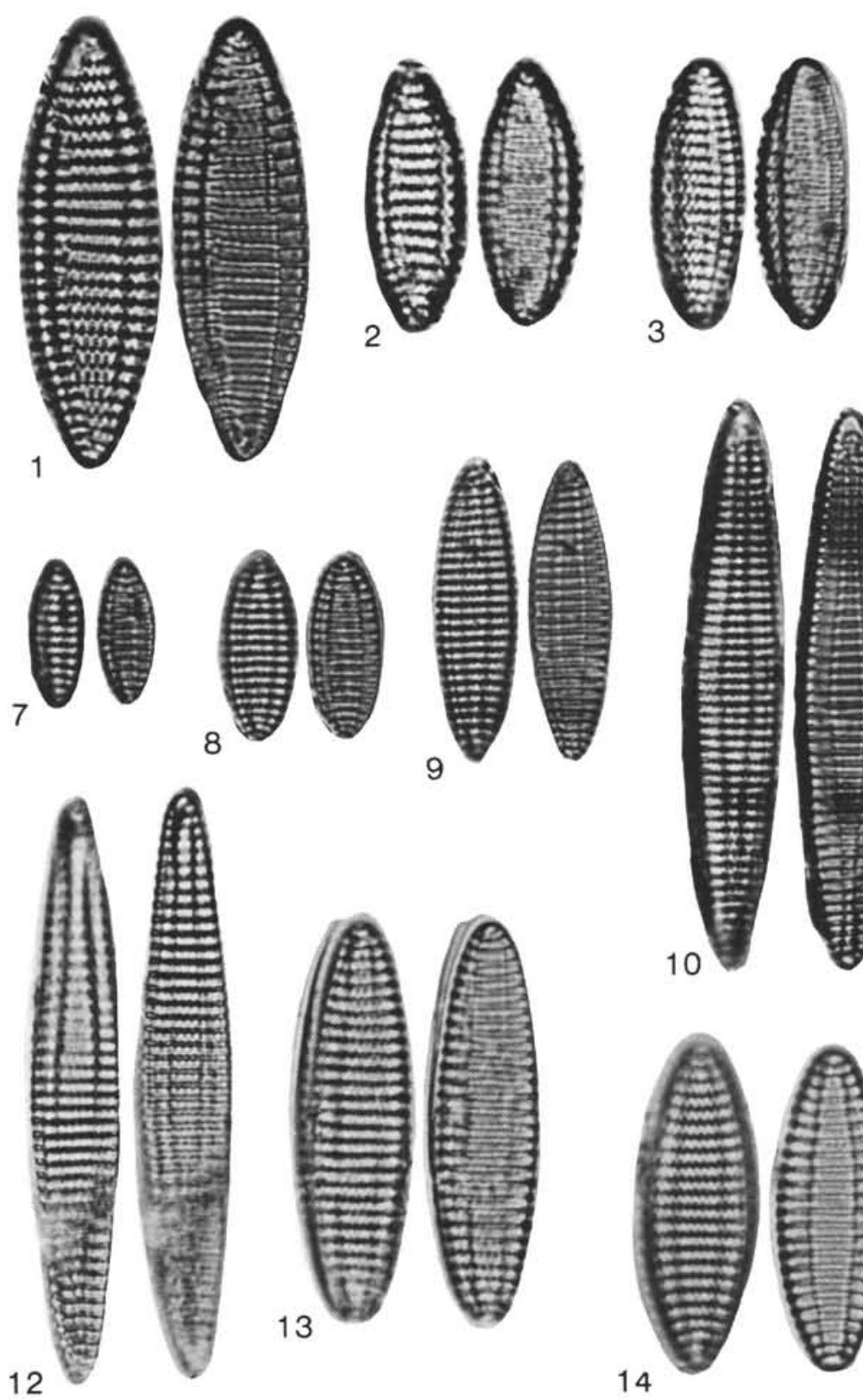

Plate 39. (All specimens magnified $\times 1500$.) 1-6. Nitzschia jouseae Burckle, (1) Sample RC12-65, type material of the species, (2) Sample $584-24, C C$, (3) Sample 584-32,CC, (4) Sample 584-6,CC, (5) Sample 584-4,CC. 7-15. Nitzschia miocenica Burckle, (7-11) Sample RC12-65, $1065 \mathrm{~cm}$, type material of the species, (12) Sample 438A-41,CC, (13-15) Sample JDS-6483, Nina Formation, Biratori Area, central Hokkaido. 

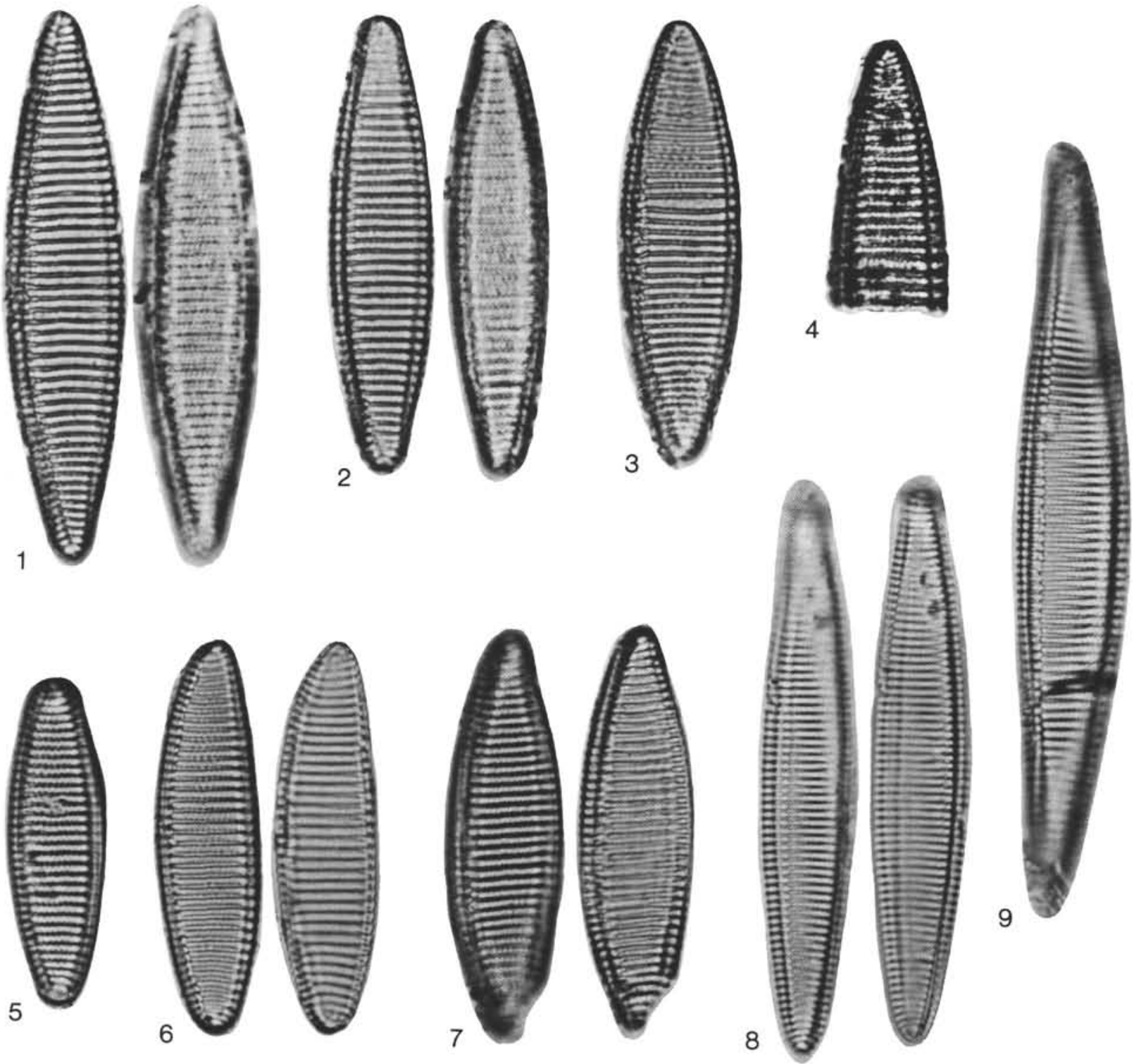

Plate 40. (All specimens magnified $\times 1500$.) 1-7. Nitzschia pliocena (Brun) Mertz, (1-3) Sample "Calcaire de Sendai," type material of the species, (4) Sample 584-59,CC, (5-7) Sample JDS-7138, Nina Formation, Kiyomappu Area, central Hokkaido. 8-9. Nitzschia reinholdii Kanaya ex Schrader, Sample JDS-6494, Nina Formation, Biratori Area, central Hokkaido. 

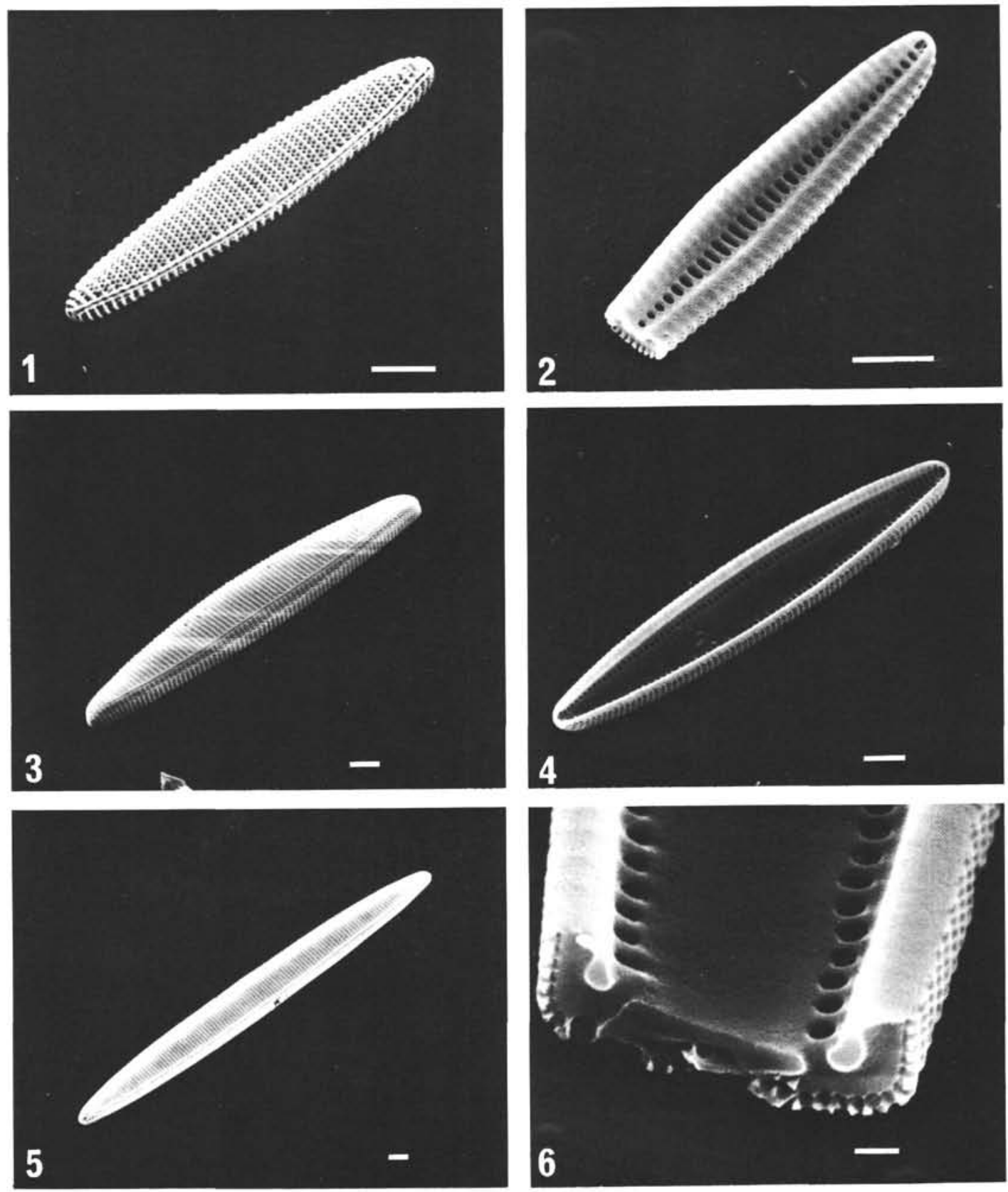

Plate 41. (Scale bar $=5 \mu \mathrm{m}$.) Sample RC12-65, $1065 \mathrm{~cm}$. 1-2. Nitzschia miocenica Burckle, (1) oblique view of valve exterior, (2) oblique view of valve interior, note a row of large foramina and chamber structure. 3-4. Nitzschia reinholdii Kanaya ex Schrader, (3) oblique view of valve exterior, (4) oblique view of valve interior, note two rows of inner pores near margins. 5-6. Nitzschia marina Grunow, (5) oblique view of valve exterior, (6) enlarged view of cross section of valve, note two rows of inner pores near margins and chamber structure with raphe canal (bar $=1 \mu \mathrm{m}$ ). 


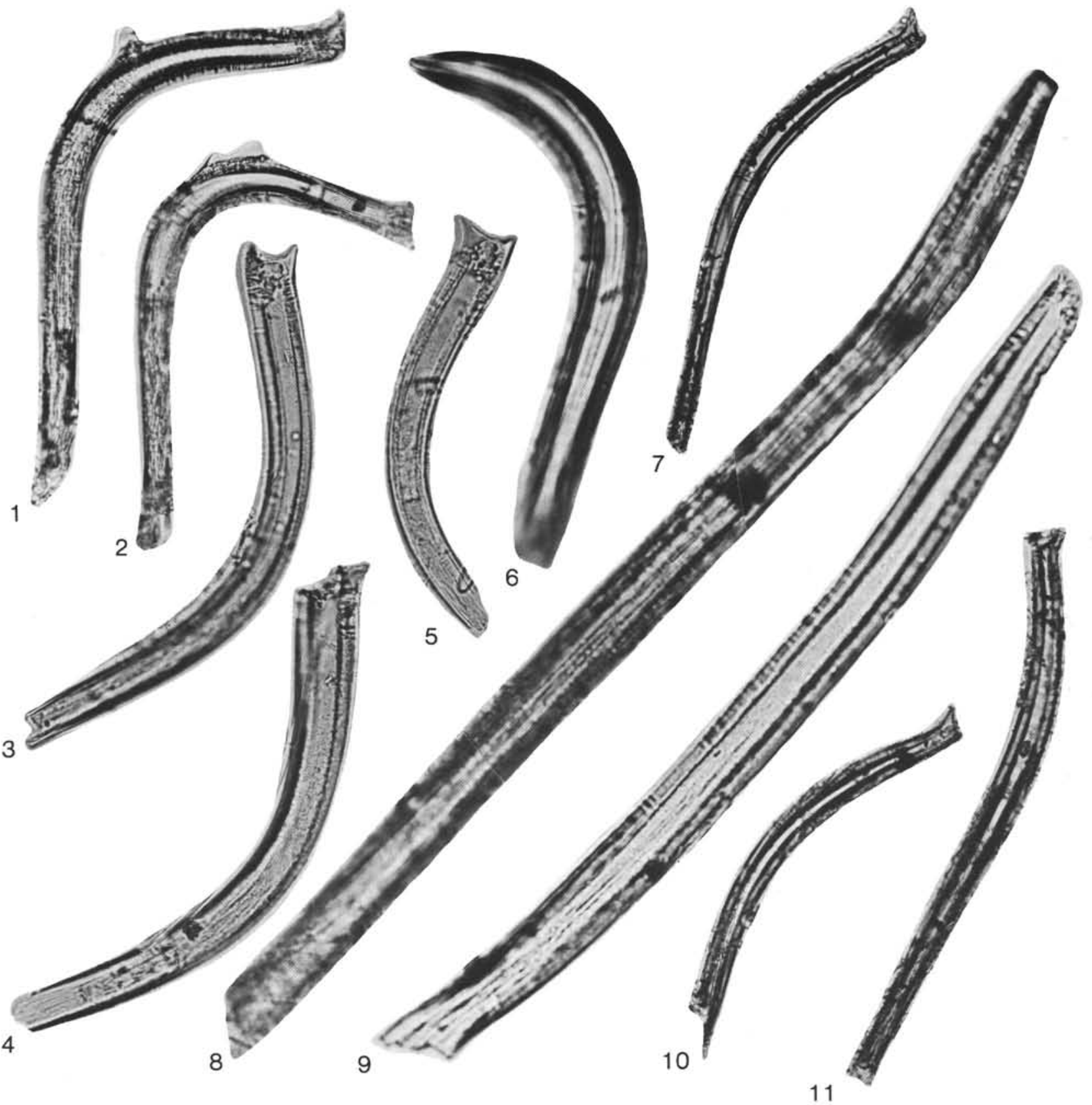

Plate 42. (All specimens magnified $\times 600$ unless otherwise indicated.) 1-2. Rhizosolenia curvirostris Jousé, Sample JDS-12711, dredge material, off Otsuchi, northeastern Honshu. 3-5, 7, 10-11. Rhizosolenia barboi (Brun) Tempère and Peragallo, (3-5) Sample RC12-420, 750 cm, Bering Sea, $(7,10-11)$ Sample 584-13,CC. 6. Rhizosolenia interposita Hajós, Sample JDS-8789, a calcareous nodule from Okuyama Conglomerate of Sakuma Formation, Bōsō Peninsula, central Japan (magnified $\times 1500$ ). 8-9. Rhizosolenia praebarboi Schrader, (8) Sample JDS-8789, the same sample as above (magnified $\times 1500$ ), (9) Sample JDS-3663, Yuni Formation, Umaoiyama Area, central Hokkaido. 

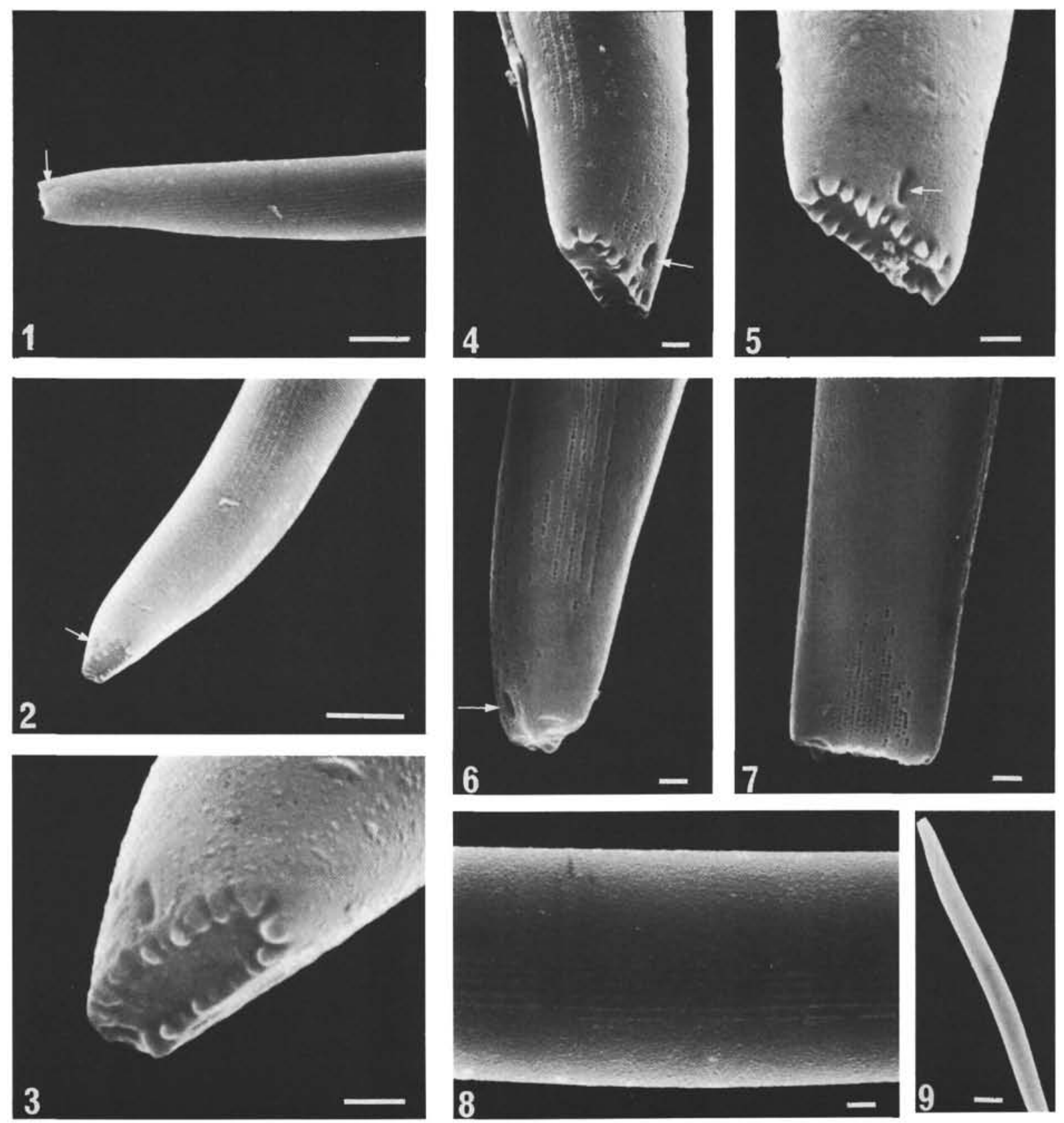

Plate 43. Rhizosolenia praebarboi Schrader, Sample JDS-8865, Masuura Formation, Abashiri Area, eastern Hokkaido. 1-2. Dentate end, arrow indicates longitudinal slit $(\mathrm{bar}=5 \mu \mathrm{m})$. 3. Enlarged view of Figure $2(\mathrm{bar}=1 \mu \mathrm{m})$. 4-5. Dentate end, arrow indicates longitudinal slit (bar $=1 \mu \mathrm{m})$. 6-7. Dentate end (bar $=1 \mu \mathrm{m})$, (6) slightly convex side with longitudinal slit (arrow), (7) flat side without longitudinal slit. 8. Surface of tube with several striae of very fine puncta $(\mathrm{bar}=1 \mu \mathrm{m})$. 9. Apical tube (bar $=10 \mu \mathrm{m})$. 

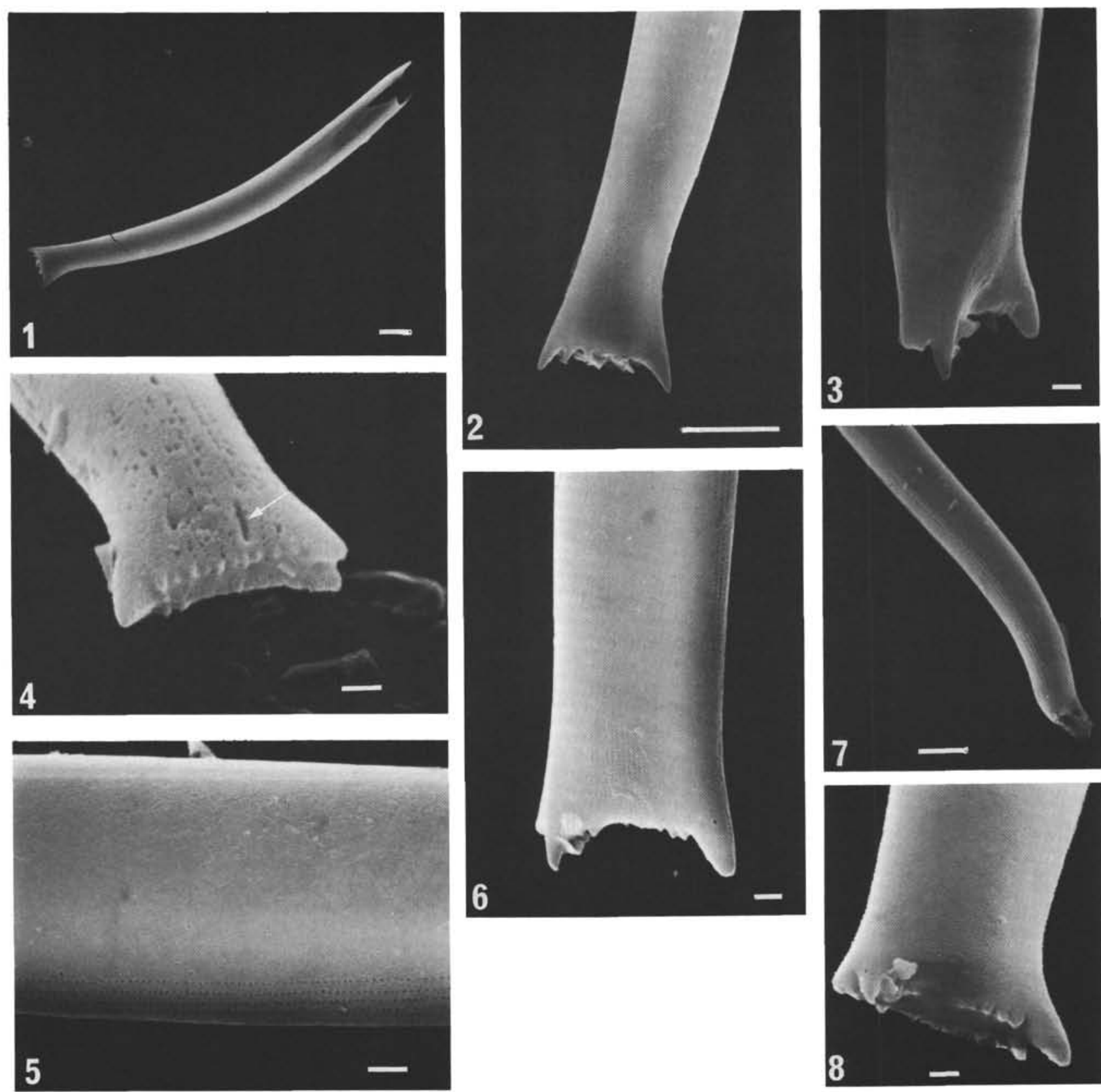

Plate 44. (Scale bar $=5 \mu \mathrm{m}$ unless otherwise indicated.) Rhizosolenia barboi Brun, Sample 438A-53-2, 30-31 cm, northwestern Pacific. 1. Apical tube. 2. Dentate end. 3. Dentate end of specimen in Figure 2 in view from the other direction (bar $=1 \mu \mathrm{m})$. 4. Dentate end with a longitudinal slit $(\mathrm{bar}=1 \mu \mathrm{m})$. 5. Surface of tube with several striae of very fine puncta $(\mathrm{bar}=1 \mu \mathrm{m})$. $7, \mathbf{9}$. Dentate end $(\mathrm{bar}=1 \mu \mathrm{m})$. $\quad 6,8$. Apical tube. 

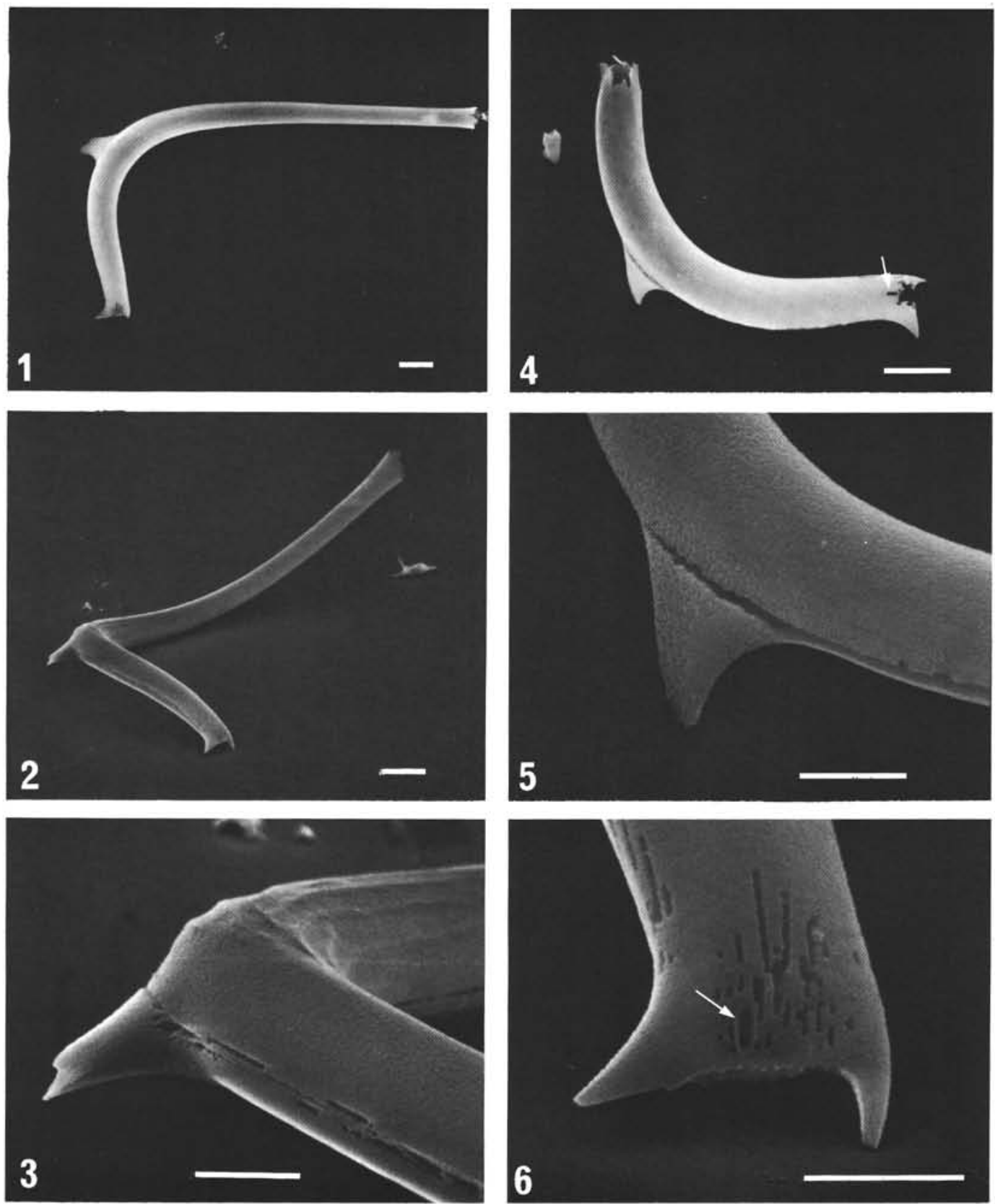

Plate 45. Rhizosolenia curvirostris Jousé, Sample 183-5,CC. 1-2. Apical tube (bar $=10 \mu \mathrm{m}$ ). 3. Enlarged view of Figure 2, showing a triangular spine $(\mathrm{bar}=5 \mu \mathrm{m})$. 4. Apical tube $(\mathrm{bar}=10 \mu \mathrm{m})$. 5. Enlarged view of Figure 2, showing a triangular spine $(\mathrm{bar}=5 \mu \mathrm{m})$. 6. Dentate end with a longitudinal slit (arrow) (bar $=5 \mu \mathrm{m}$ ). 

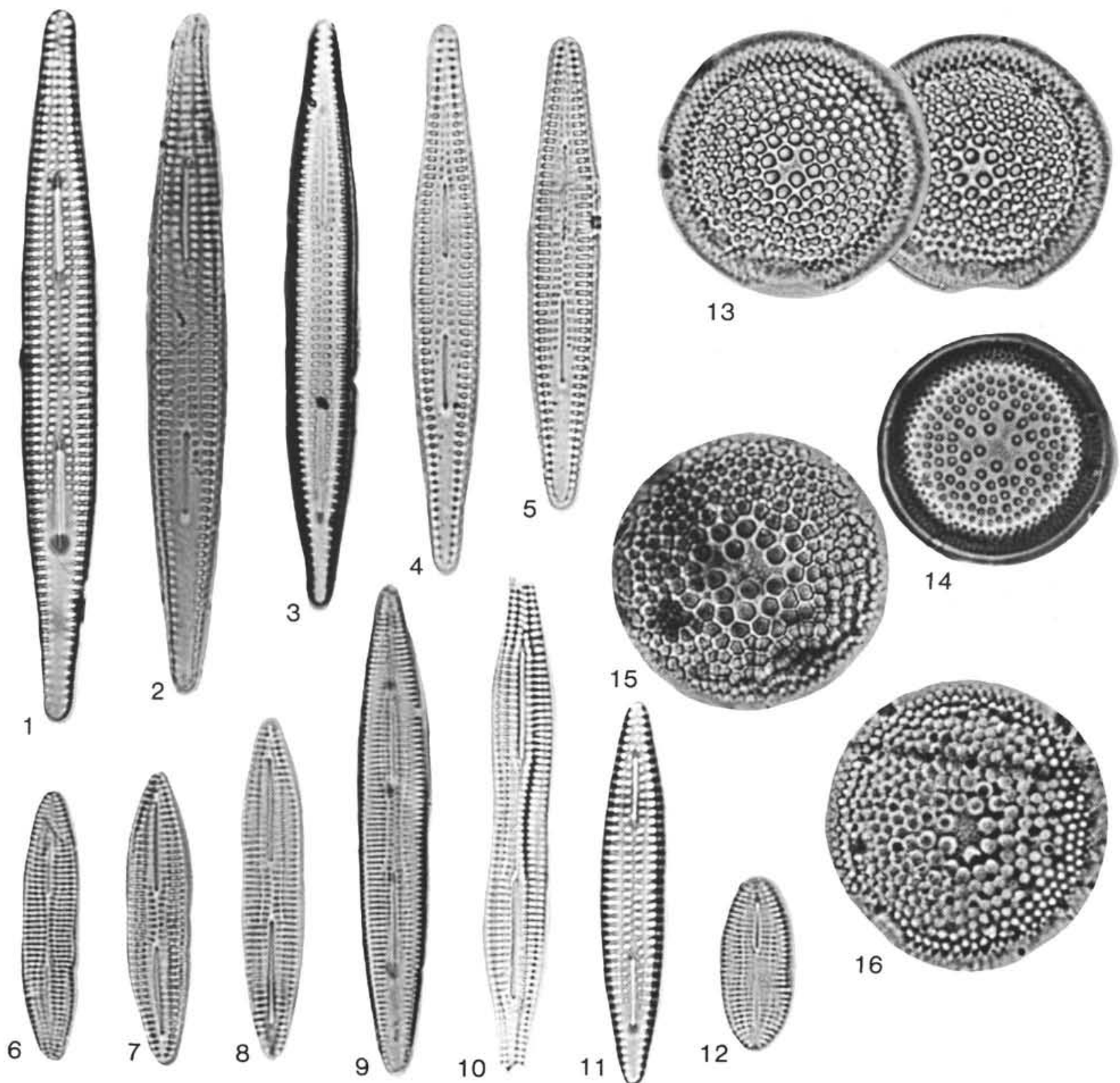

Plate 46. (All specimens magnified $\times 1500$.) 1-5, 11. Rouxia california M. Peragallo, (1, 11) Sample JDS-11685, Atsunai Formation, Atsunai Area, eastern Hokkaido, (2) Sample JDS-7163, Nina Formation, Kiyomappu Area, central Hokkaido, (3) Sample "Calcaire de Sendai." 6-8, 12. Rouxia cf. peragalli Brun and Héribaud, Sample JDS-11452, Chokubetsu Formation, Atsunai Area, eastern Hokkaido. 9-10. Rouxia cf. californica M. Peragallo, (9) Sample "Calcaire de Sendai," (10) Sample 11452, Chokubetsu Formation, Atsunai Area, eastern Hokkaido. 13, 15-16. Actinocyclus oculatus Jousé, Sample RC12-420, $755 \mathrm{~cm}$. 14. Actinocyclus ochotensis Jousé, Sample RC12-420, $755 \mathrm{~cm}$. 

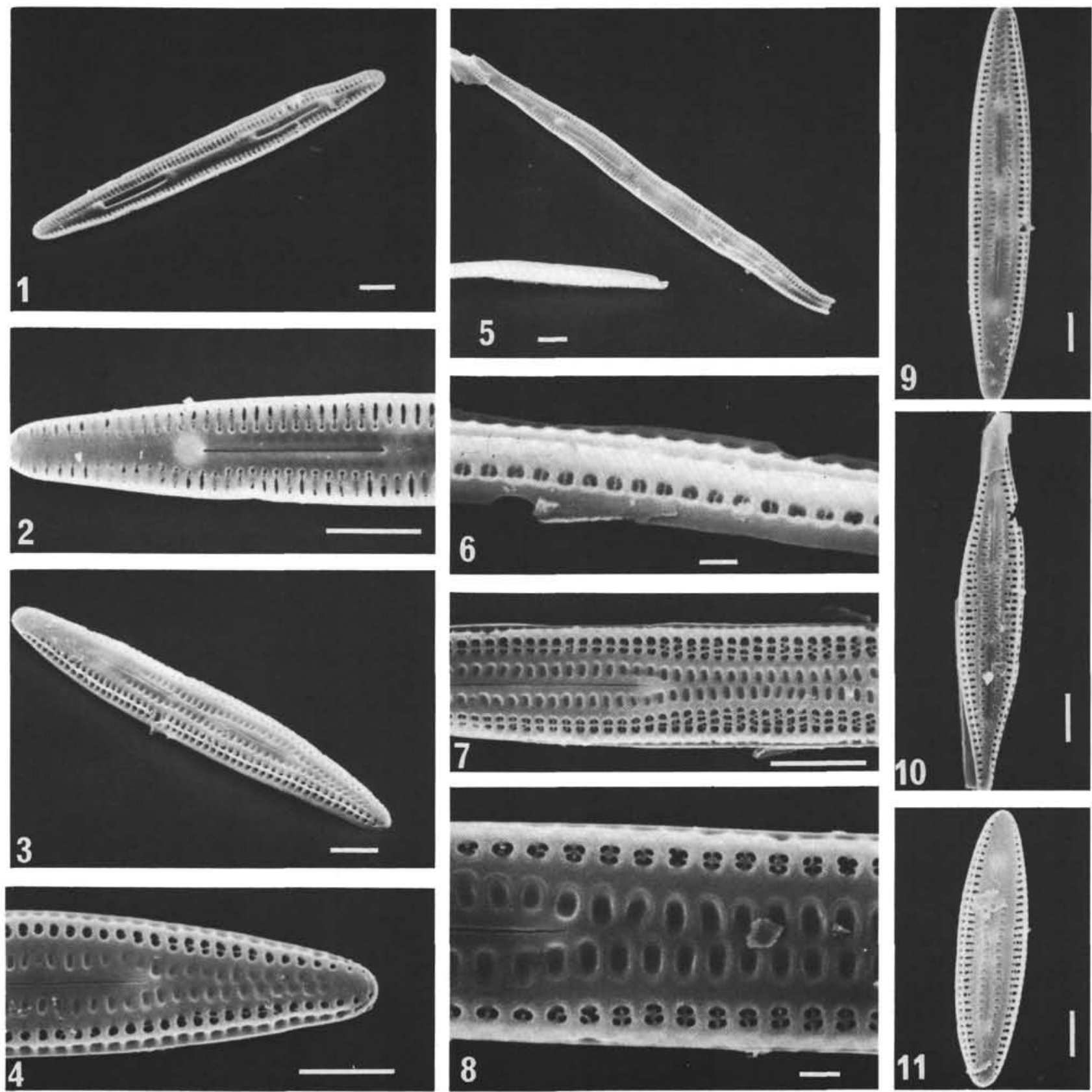

Plate 47. (Scale bar $=5 \mu \mathrm{m}$ unless otherwise indicated.) Rouxia californica M. Peragallo. Sample 438A-53-2, 30-31 cm, northwestern Pacific. 1. Oblique view of valve interior. 2. Apical part of valve interior. 3. Oblique view of valve exterior. 4. Apical part of valve exterior. 5. Oblique view of valve interior. 6. Girdle view of valve $(\mathrm{bar}=1 \mu \mathrm{m})$. 7-8. Enlarged views of valve exterior, $(8) \mathrm{bar}=1 \mu \mathrm{m}$. 9-11. Valve exterior. 

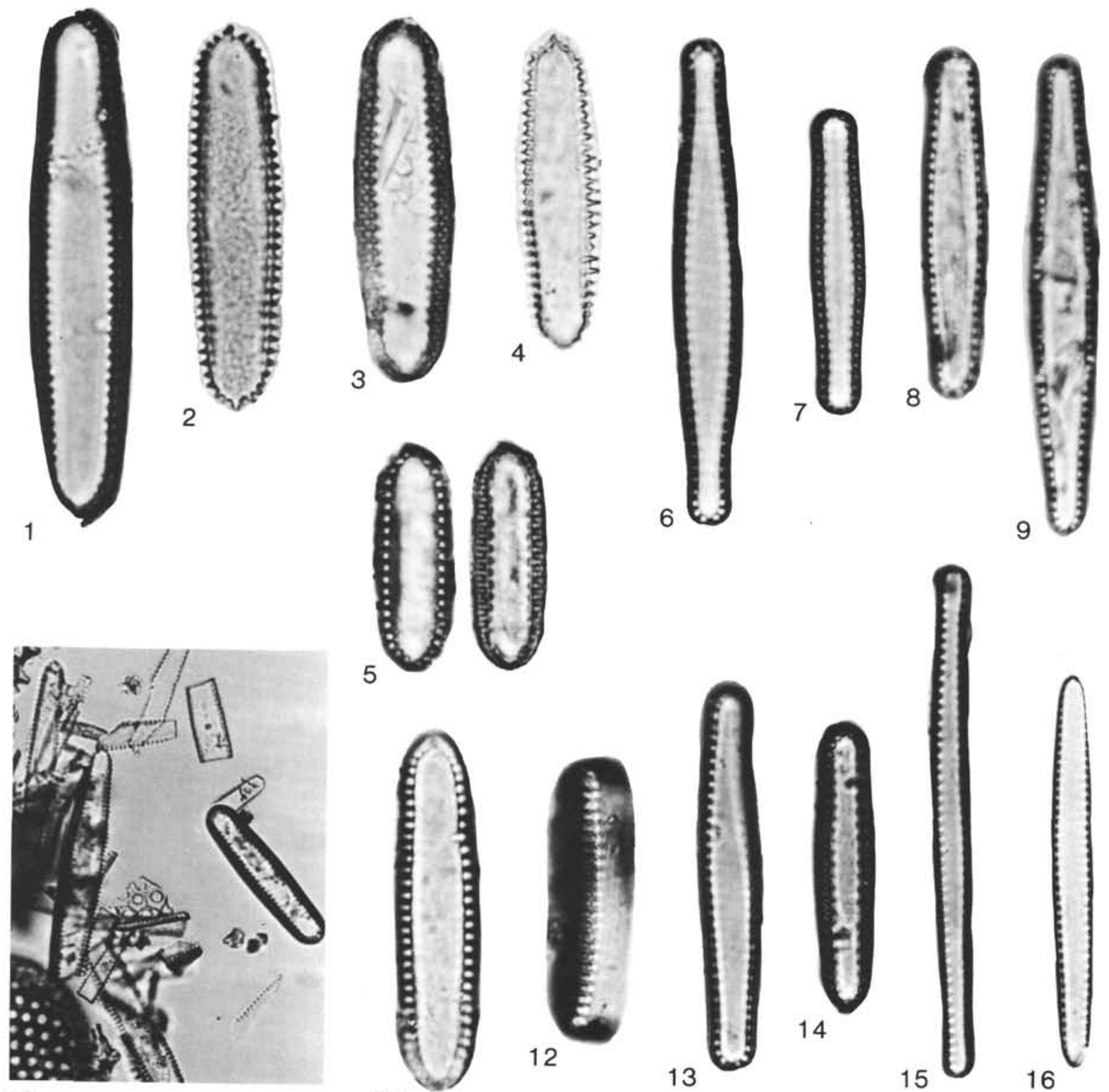

Plate 48. (All specimens magnified $\times 1500$.) 1-5, 10-12. Thalassionema schraderi Akiba, (1) Sample JDS-5239, type material of the species, Kubo Formation, Ninohe Area, northeastern Honshu, $(2,10)$ Sample 183-18-3, 80-82 cm (2, valve without mantle), (3) Sample N6b, Monterey Formation, Newport Beach Section, California, $(4,12)$ Sample JDS-4554, Shinzan Diatomite, Oga Peninsula, northeastern Honshu $(4$, valve without mantle), (5) Sample JDS-8304, Atsunai Formation, Atsunai Area, eastern Hokkaido, (11) Sample NEW 51, Monterey Formation from the same section as Figure 3. 6-9, 13-14. Thalassionema hirosakiensis (Kanaya) Schrader, (6-7) Sample JDS-11452, Chokubetsu Formation, Atsunai Area, eastern Hokkaido, (8-9) Sample A23, diatom Loc. 4, slide No. 1, type slide of the species, (13) Sample JDS-4550, Shinzan Diatomite, (14) Sample 183-19-2, 80-82 cm. 15-16. Thalassionema nitzschioides (Grunow) H. and M. Peragallo, (15) Sample JDS-4550, Shinzan Diatomite, (16) Sample JDS-2289, Koetoi Formation, Tenpoku Area, northern Hokkaido. 

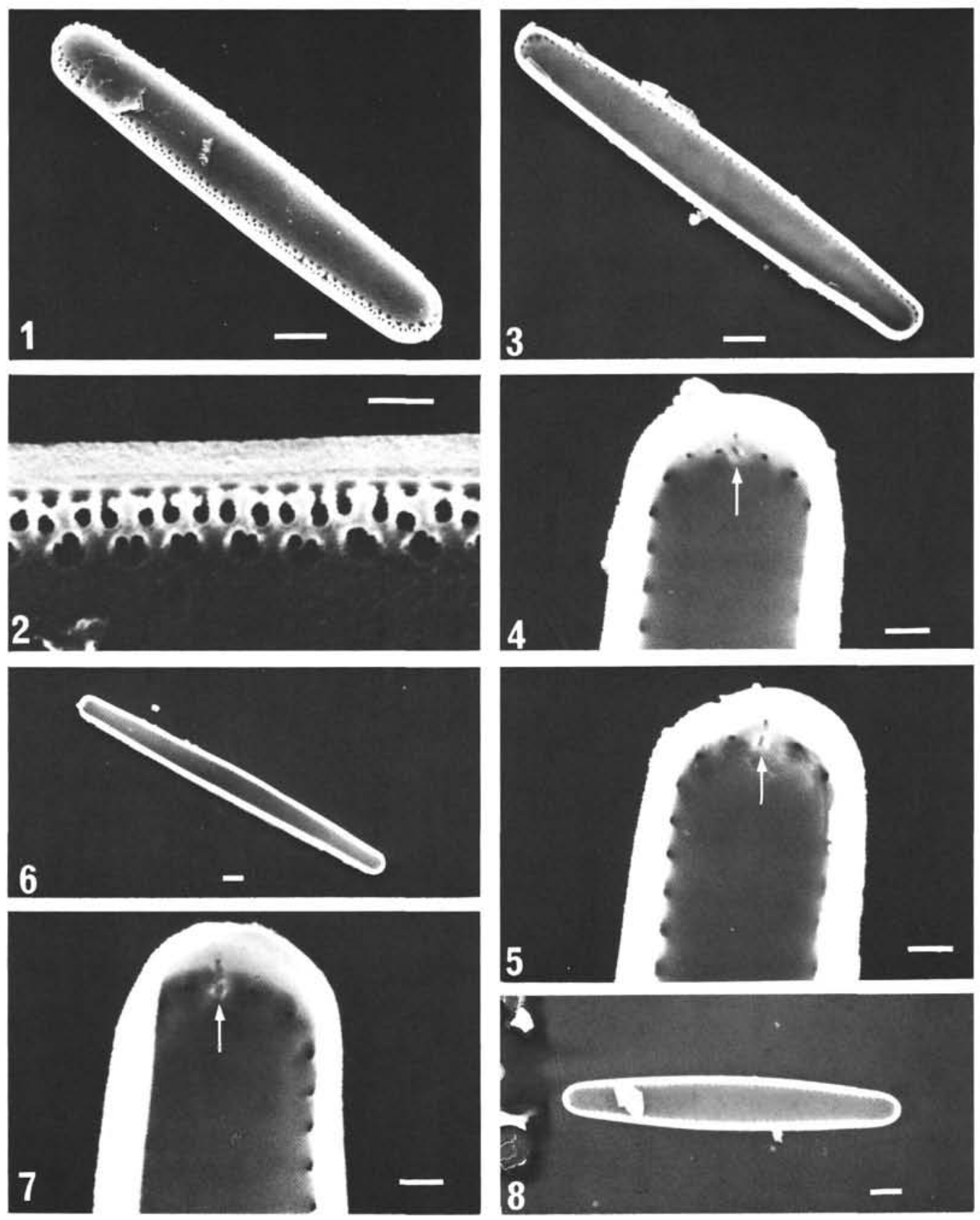

Plate 49. Thalassionema hirosakiensis (Kanaya) Schrader, Sample 438A-53-2, 30-31 cm, northwestern Pacific. 1. Valve exterior (bar $=5 \mu \mathrm{m})$,

2. Enlarged view of specimen shown in Figure $1(\mathrm{bar}=1 \mu \mathrm{m})$. 3. Valve interior $(\mathrm{bar}=1 \mu \mathrm{m})$. 4. An apical part of valve shown in Figure 3, arrow indicates labiate process, note small pore above labiate process $($ bar $=1 \mu \mathrm{m})$. 5. The other apical part of valve shown in Figure 3, arrow indicates labiate process $(\mathrm{bar}=1 \mu \mathrm{m})$. 6. Valve interior $(\mathrm{bar}=5 \mu \mathrm{m})$. 7. Apical part of valve shown in Figure 6, arrow indicates labiate process $($ bar $=1 \mu \mathrm{m})$. 8. Valve interior (bar $=5 \mu \mathrm{m})$. 

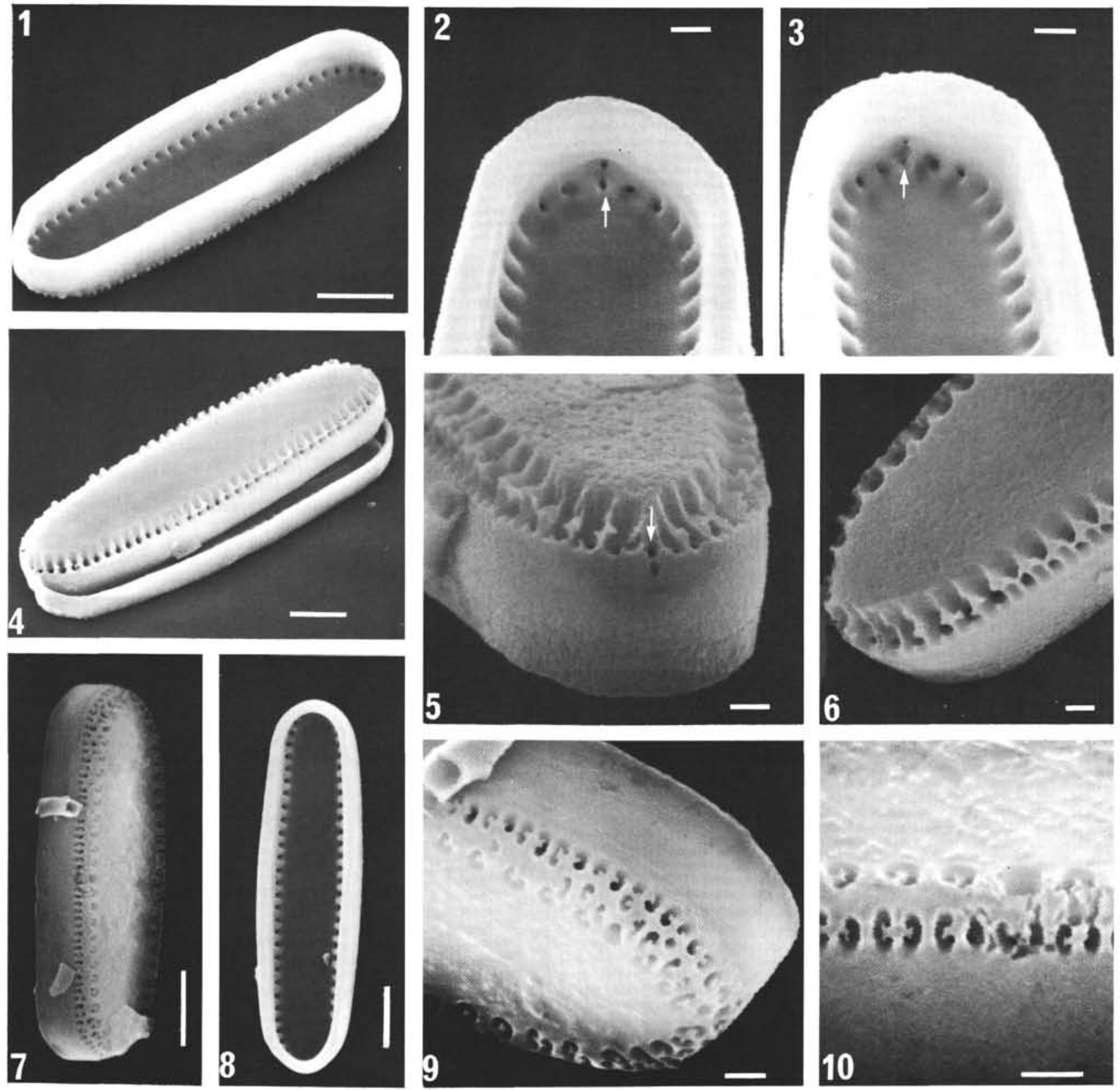

Plate 50. Thalassionema schraderi Akiba, Sample 438A-45-7, 10-11 cm, northwestern Pacific. 1 . Oblique view of valve interior $($ bar $=5 \mu \mathrm{m})$. 2-3. Apical portions of valve shown in Figure 1, arrows indicate labiate processes (bar $=1 \mu \mathrm{m})$. 4. Oblique view of valve exterior (bar $=$ $5 \mu \mathrm{m})$. 5-6. Apical portions of valve shown in Figure 4, arrow indicates outer opening of labiate process (bar $=1 \mu \mathrm{m}$ ). 7 . Oblique girdle view of valve exterior $(\mathrm{bar}=5 \mu \mathrm{m})$. 8. Valve interior $($ bar $=5 \mu \mathrm{m})$. 9. Enlarged view of exterior of valve shown in Figure $7($ bar $=1 \mu \mathrm{m})$. 10 . Two rows of puncta (bar $=1 \mu \mathrm{m})$. 

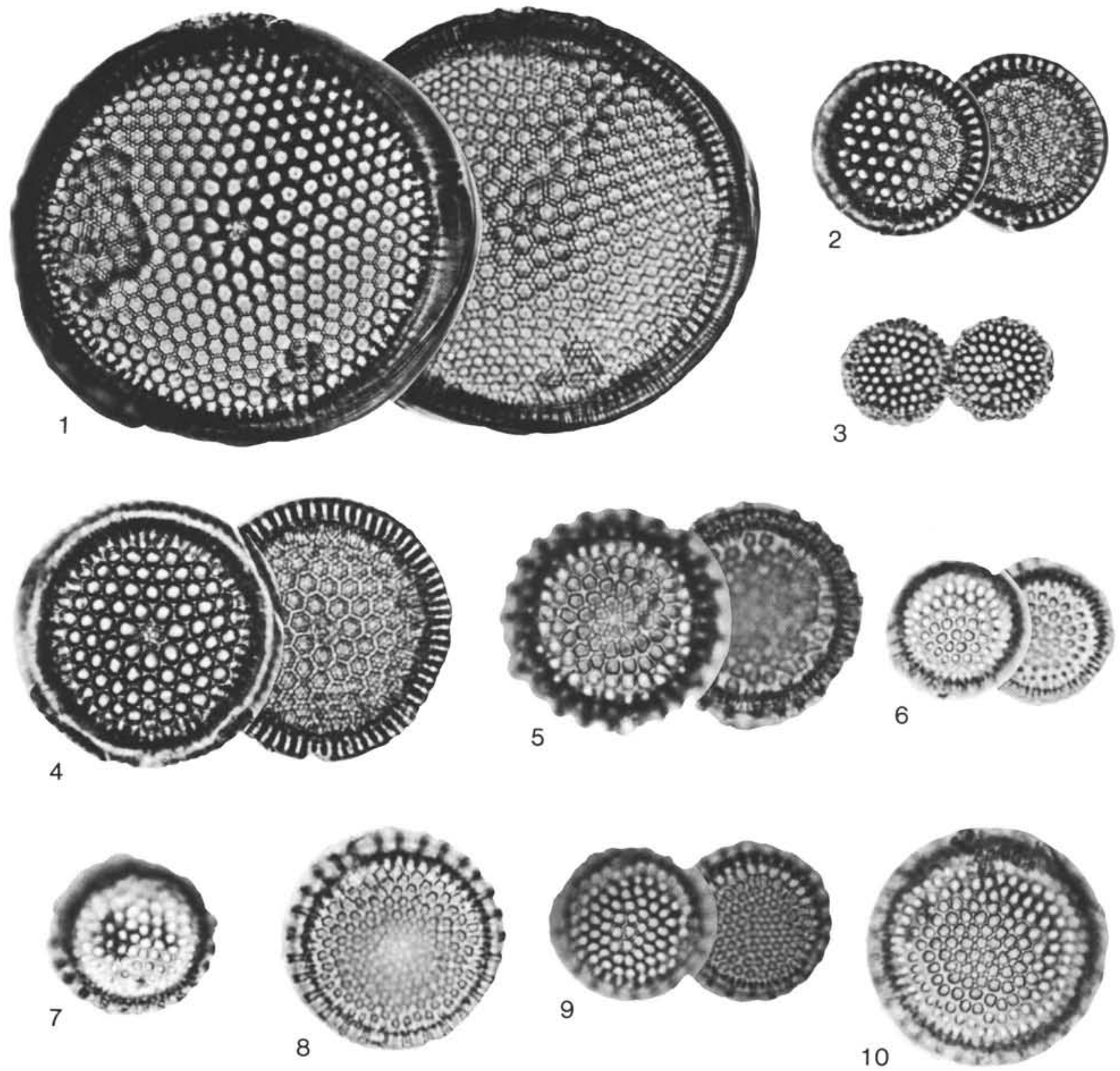

Plate 51. (All specimens magnified $\times 1500$.) 1-2, 4. Thalassiosira antiqua (Grunow) Cleve-Euler, Sample 438-42,CC. 3. Thalassiosira burckliana Schrader, Sample 584-63-2, 123-124 cm. 5-10. Thalassiosira fraga Schrader, (5, 8-10) Sample JDS-8789, a calcareous nodule from Okuyama Conglomerate of Sakuma Formation, Bōsō Peninsula, central Japan, (6) Sample JDS-8482, Kiroro Formation, Honbetsu Area, eastern Hokkaido, (7) Sample JDS-8665 from the same stratum as Figure 6. 

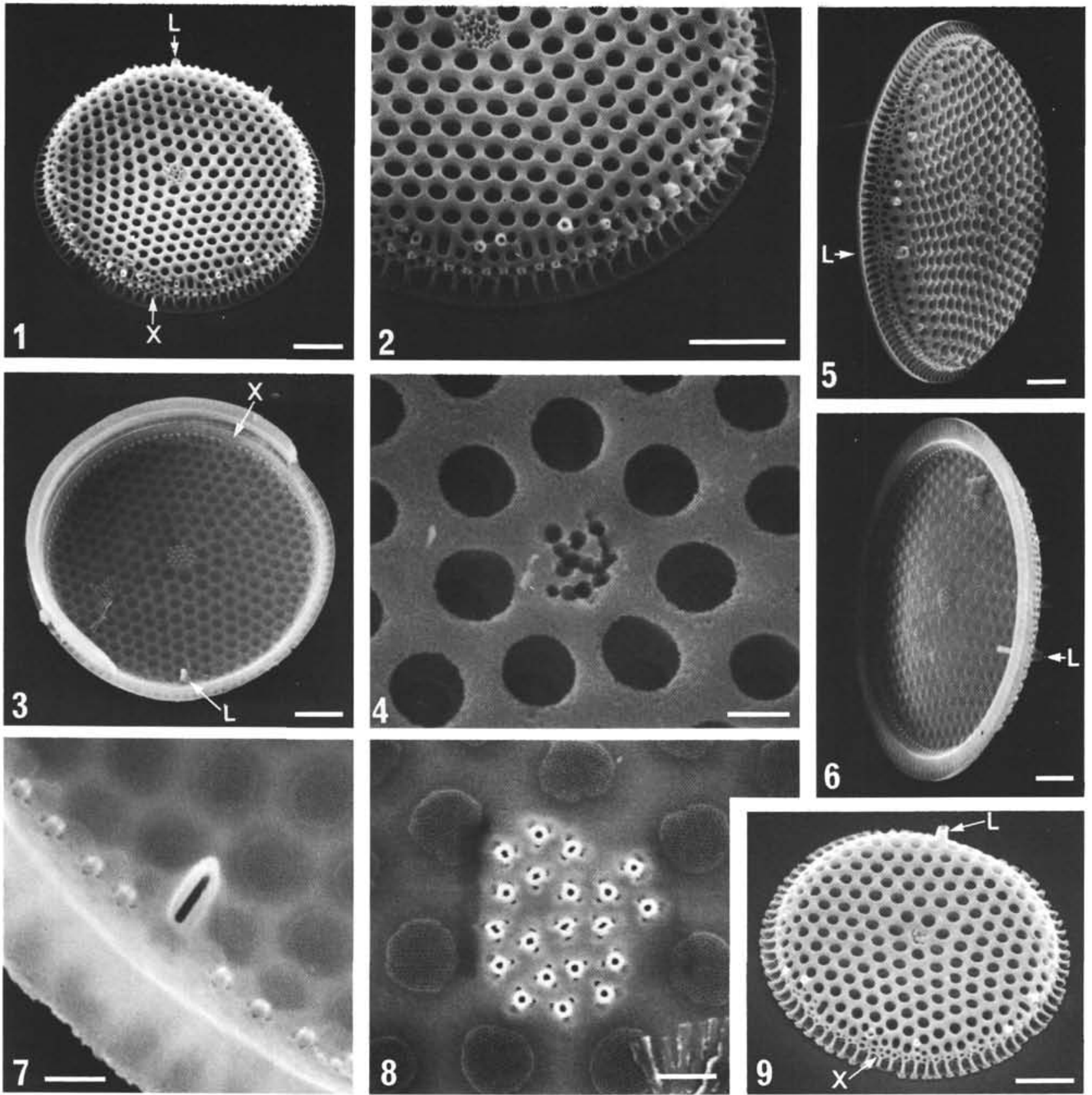

Plate 52. Thalassiosira antiqua (Grunow) Cleve, Sample 438A-42,CC, northwestern Pacific. $\mathrm{L}$ indicates labiate process and X indicates the point where a ring of marginal strutted processes is interrupted. 1. Oblique view of valve exterior $(\mathrm{bar}=5 \mu \mathrm{m})$. 2. Enlarged view of specimen shown in Figure 1, note tubular occluded processes inside the ring of strutted processes $(\mathrm{bar}=1 \mu \mathrm{m})$. 3. Oblique view of valve interior $(\mathrm{bar}=$ $5 \mu \mathrm{m})$. 4. Enlarged view of center of valve exterior $(\mathrm{bar}=1 \mu \mathrm{m})$. 5-6. Oblique girdle views of valve (bar $=5 \mu \mathrm{m})$, $(5)$ valve exterior, $(6)$ valve interior. 7. Margin of valve interior, labiate process and marginal strutted processes (bar $=1 \mu \mathrm{m})$. 8. Center of valve interior, many strutted processes with three struts $(\mathrm{bar}=1 \mu \mathrm{m})$. 9. Oblique view of valve exterior (bar $=5 \mu \mathrm{m})$. 

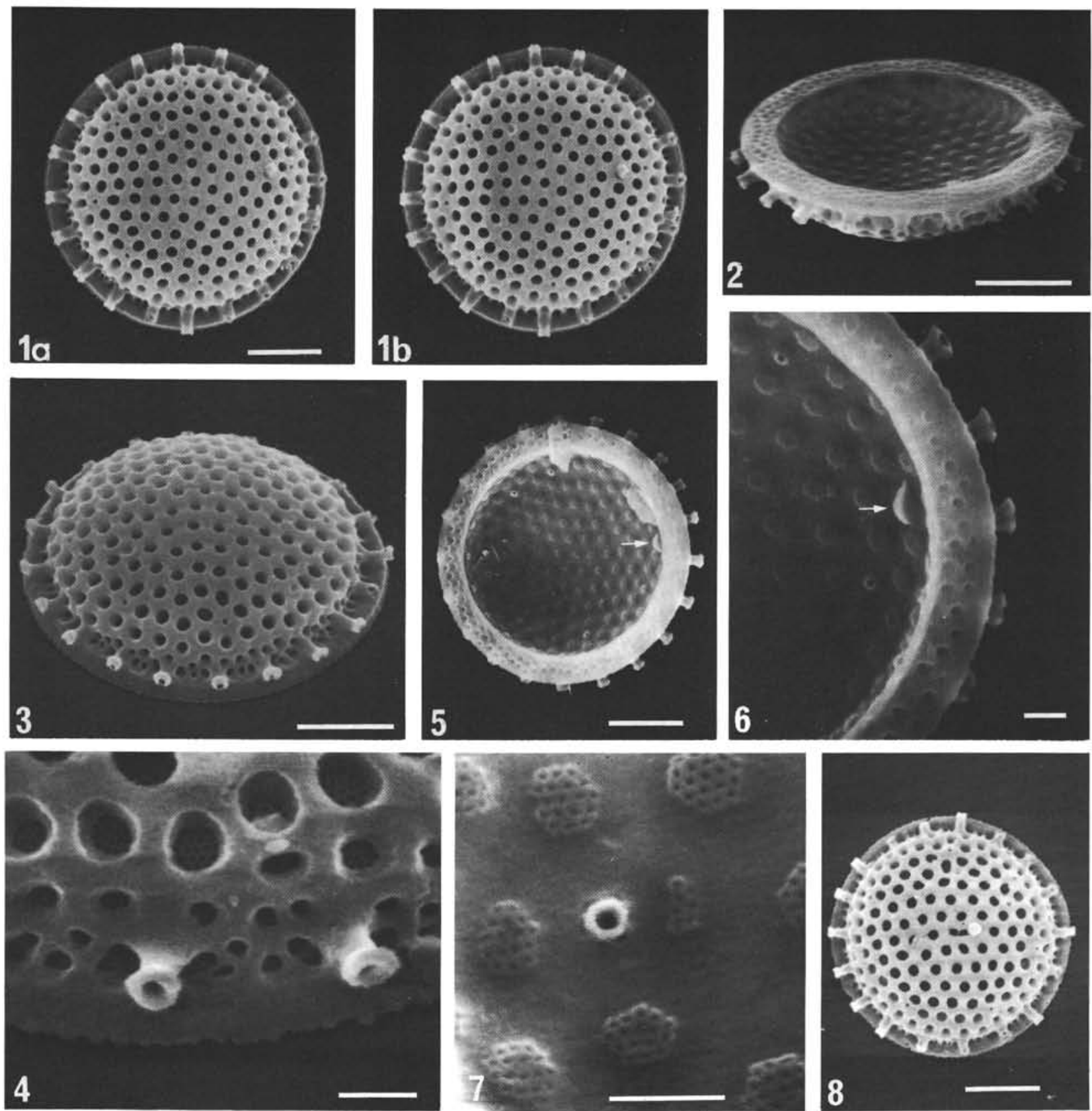

Plate 53. (Scale bar $=5 \mu \mathrm{m}$ unless otherwise indicated.) Thalassiosira fraga Schrader, Sample JDS-10648, Hata Formation, Bōsō Peninsula, central Japan. 1A-B. Valve exterior (stereoscopic pair). 2. Oblique view of valve interior. 3. Oblique view of valve exterior. 4. Enlarged view of Figure 3, showing outer tubes of marginal strutted processes (bar $=1 \mu \mathrm{m})$. 5. Valve interior; arrow indicates labiate process. 6. Enlarged view of Figure 4; arrow indicates labiate process $(\mathrm{bar}=1 \mu \mathrm{m})$. 7. Internal view of strutted process inside a ring of marginal strutted processes (bar $=1 \mu \mathrm{m})$. 8. Valve exterior. 